BRENDA DE OLIVEIRA

\title{
Tradução Intersemiótica na elaboração da Dramaturgia do Ator: Pedagogia e Encenação
}

Dissertação apresentada ao Departamento de Artes Cênicas da Escola de Comunicação e Artes da Universidade de São Paulo como exigência para obtenção do Título de Mestre em Artes.

Área de Concentração: Pedagogia do Teatro - Formação do Artista Teatral

Orientador: Prof. Dr. Armando Sérgio da Silva

São Paulo 
Autorizo a reprodução e divulgação total ou parcial deste trabalho, por qualquer meio convencional ou eletrônico, para fins de estudo e pesquisa desde que citada a fonte.

\section{Catalogação na publicação Serviço de Biblioteca e Documentação Escola de Comunicação e Artes da Universidade de São Paulo}

De Oliveira, Brenda.

Tradução Intersemiótica na elaboração da Dramaturgia do Ator: Pedagogia e Encenação / Brenda de Oliveira - São Paulo: USP. 198p. : il.+ DVD

Dissertação (Mestrado) - Universidade de São Paulo, Escola de Comunicações e Arte, CAC, 2012.

Orientador: Prof. Dr. Armando Sérgio da Silva

1. Tradução Intersemiótica 2. Dramaturgia do Ator 3. Criação 4. Encenação I. Silva, Armando Sérgio. II. Universidade de São Paulo. Escola de Comunicações e Artes. III. Título 


\section{FOLHA DE APROVAÇÃO}

\section{Brenda de Oliveira}

Tradução Intersemiótica na elaboração da Dramaturgia do Ator: Pedagogia e Encenação

Dissertação apresentada ao Departamento de Artes Cênicas da Escola de Comunicação e Artes da Universidade de São Paulo como exigência para obtenção do Título de Mestre em Artes.

Área de Concentração: Pedagogia do Teatro - Formação do Artista Teatral

Aprovado em: 1

Banca Examinadora 


\section{Agradecimentos}

Ao professor Dro ${ }^{\mathrm{o}}$. Armando Sérgio da Silva, pela confiança e oportunidade única.

Ao professor Dro . Eduardo Coutinho, pela co-orientação e constante atenção.

À professora Dra Cecília Salles, por trazer o entendimento e o olhar que faltavam.

Aos colegas e pesquisATORES do CEPECA, pelas colaborações. Sou muito grata a: Rejane Arruda Kasting, Evinha Sampaio, Suzana Alves, Cadu Witter, Gisela Lourenção, Adriano Cypriano, Umberto Cerasoli Jr., Camila Scudeler, Renata Kamla, João Bourbonnais, Patrícia Noronha, Maritza Farías Cerpa, Renata Mazzei, Eduardo de Paula, Marcelo Braga, Rogério de Moura.

Aos artistas e acadêmicos: Bru Palmieri e Marcello Amalfi, pelas trocas e contribuições.

Aos artistas e parceiros: Michaella Andrade e Fernando Puch, pela arte gráfica da capa, Tatiana Almeida e Dulce Dubovski pela produção e fotos na Mostra Experimentos.

Aos familiares e amigos, pelo incondicional apoio e compreensão.

Especialmente a: Bruna Lima, Christiane Martins, Áurea Teixeira Barros, Fabiano Benigno, Patusca, Elton Santos e João Attuy. Vocês me proporcionaram o melhor desses dois anos. Sem vocês, não teria sido possível. 
Essa pesquisa foi realizada com apoio financeiro da FUNDAÇÃO DE APOIO À PESQUISA DO ESTADO DE SÃO PAULO FAPESP 


\section{RESUMO}

Pesquisa sobre Dramaturgia do ator e Tradução Intersemiótica como formas de pensar a Interpretação e a Encenação, respectivamente. Com este objetivo, aproxima-se o signo teatral de outras linguagens - Artes Plásticas e Cinema para, através dos Estudos Genéticos, compreender o processo criativo que nos levou a dois exercícios cênicos: Efêmea e ...E fêmea.

Palavras-chave: Tradução Intersemiótica, Dramaturgia do Ator, Pedagogia, Encenação, Estudos Genéticos, Toulouse-Lautrec, Jean-Luc Godard, Linguagem 


\begin{abstract}
This is a research about Dramaturgy of the actor and Intersemiotic Translation as a way of thinking about Acting and Staging, respectively. In order to do so, we relate the theatrical sing to other languages - Crafts and Cinema - for understanding, through Genetics Studies, the creative process which conducted us to both scenic exercises: Efêmea and ...E fêmea.
\end{abstract}

Key words: Intersemiotic Translation, Dramaturgy of the actor, Pedagogy, Staging, Genetic Studies, Toulouse-Lautrec, Jean-Luc Godard, Language 


\section{LISTA DE FIGURAS}

FIGURA 1: MAPA DOS ESTUDOS DA TRADUÇÃO (PÁG. 31)

FIGURA 2: EXEMPLO DE PLANO GERAL - NO TEMPO DAS DILIGÊNCIAS (PÁG. 58)

FIGURA 3: EXEMPLO DE PLANO DE CONJUNTO - L'APOLLONIDE (PÁG. 58)

FIGURA 4: EXEMPLO DE PLANO ABERTO - VIVER A VIDA (PÁG. 59)

FIGURA 5: EXEXMPLO DE PLANO AMERICANO - VIVER A VIDA (PÁG. 59)

FIGURA 6: EXEMPLO DE PLANO MÉDIO - L'APOLLONIDE (PÁG 60)

FIGURA 7: EXEXMPLO DE PRIMEIRO PLANO - VIVER A VIDA (PÁG. 60)

FIGURA 8: EXEXMPLO DE PLANO PRÓXIMO - VIVER A VIDA (PÁG. 61)

FIGURA 9: EXEXMPLO DE PRIMEIRÍSSIMO PLANO PRÓXIMO - VIVER A VIDA (PÁG. 62)

FIGURA 10: EXEMPLO DE PLANO DE DETALHE - RECONSTRUCTION (PÁG. 62)

FIGURA 11: THE PAINTER'S FAMILY - MATISSE (PÁG. 69)

FIGURA 12: SLEEPING PEASENTS - PICASSO (PÁG. 69)

FIGURA 13: A CARTA E A CHAMINÉ - BRUMAS DE OUTONO (PÁG. 73)

FIGURA 14: O ESPAÇO COMO LABIRINTO - BLOW UP (PÁG. 74)

FIGURA 15: O CLOSE NA MÃO, A INDUMENTÁRIA E O XALE COMO ESPACIALIZAÇÃO

DO TEMPO - BRUMAS DE OUTONO (PÁG. 75)

FIGURA 16: MY BLUEBERRY NIGHTS - WON KAR WAI (PÁG. 77)

FIGURA 17: IMAGEM PROJETADA EM WORKSHOP - NOSTALGIA (PÁG. 78)

FIGURA 18: A BAILARINA LÖIE FULLER VISTA DOS BASTIDORES - A RODA TOULOUSE-LAUTREC (PÁG. 80)

FIGURA 19 MEU NASCIMENTO - FRIDA KAHLO (PÁG. 81)

FIGURA 20: O GRITO - EDWARD MUNCH (PÁG. 82)

FIGURA 21: AS DAMAS D'AVIGNON - PICASSO (PÁG 83)

FIGURA 22: NIGHTHAWKS - EDWARD HOPPER (PÁG. 93)

FIGURA 23: RECONSTRUÇÃO DE UM AMOR - CHRISTOFFER BOE (PÁG. 93)

FIGURA 24: QUADRO DE LEITURA - FAYGA OSTROWER (PÁG 99)

FIGURA 25: LÖIE FULLER (PÁG. 100)

FIGURA 26: SEQUÊNCIA DE LINHAS I - FAYGA OSTROWER (PÁG. 102)

FIGURA 27: SEQUÊNCIA DE LINHAS II - FAYGA OSTROWER (PÁG. 102)

FIGURA 28: ETUDE DE NU - TOULOUSE-LAUTREC (PÁG. 120)

FIGURA 29: LE FEMME QUI RIT - L'APOLLONIDE (PÁG. 125)

FIGURA 30: ROUSSE (LA TOILETTE) - TOULOUSE-LAUTREC (PÁG. 148)

FIGURA 31: GUEULE DE BOIS, RETRATO DE SUZNNE VALADON - TOULOUSE-LAUTREC

(PÁG. 150)

FIGURA 32: ELLES: FEMME SUR LES DOS - LASSITUDE - TOULOUSE-LAUTREC (PÁG. 151)

FIGURA 33: L'INSPECTION MÉDICALE: FEMME DE MAISON BLONDE - TOULOUSE-

LAUTREC (PÁG. 154)

FIGURA 34: FEMME ROUSSE NUE ACCROUPIE - TOULOUSE-LAUTREC (PÁG. 154)

FIGURA 35: LE SOFA - TOULOUSE-LAUTREC (PÁG. 155)

FIGURA 36: LES DEUX AMIES - TOULOUSE-LAUTREC (PÁG. 155) 
1. INTRODUÇÃO

2. TRADUÇÃO INTERSEMIÓTICA............................................................................

3. CRÍTICA GENÉTICA

3.1. Fundamentos Metodológicos.......................................................................... 23

3.2. Obra como Processo............................................................................ 27

4. AS REDES DA PESQUISA........................................................................................... 28

4.1. Estudos Teóricos................................................................................................ 29

4.2. Oficinas Pedagógicas.......................................................................................

4.2.1. LINGUAGEM...................................................................... 45

4.2.1. 1. Artes Plásticas........................................................... 47

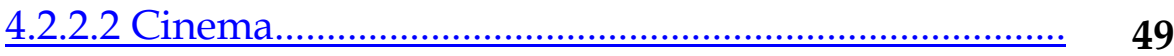

4.2.2. TEXTO........................................................................................ 94

4.2.2.1. Pinturas de Toulouse-Lautrec...................................... 96

4.2.2.2. Filmes de Jean-Luc Godard........................................ $\quad 106$

4.2.3. SIGNOS ................................................................................ 110

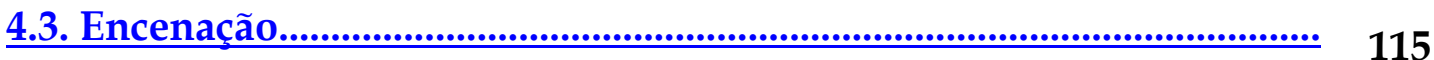

4.3.1. DRAMATURGIA DO ATOR.................................................. 116

4.3.2.1. Christiane Martins..................................................... 121

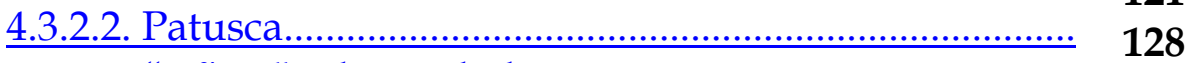

4.3.2.3. "Efêma"- plasticidade e poesia........................ 129

4.3.3. DRAMATURGIA TEXTUAL................................................... 144

4.3.3.1. Patusca ……..................................................... 146

4.3.3.2. Brenda de Oliveira......................................................... 150

4.3.3.3. "...E fêmea" - Mostra Experimentos 2012 (TUSP).... 156

5. SISTÊMICA DO OLHAR...................................................................................

5.1. Tradução Icônica................................................................................................ 158

5.2. Tradução Indicial.......................................................................................... 159

5.3. Tradução Simbólica........................................................................................ $\quad 160$

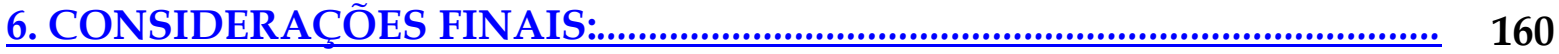

BIBLIOGRAFIA............................................................................................................. 163

ANEXOS............................................................................................................. 167 


\section{INTRODUÇÃO}

Durante os meus estudos de graduação no curso de Letras - Língua Inglesa, tomei contato com algumas teorias do campo dos Estudos da Tradução. Logo foi possível identificar que a prática da tradução pontua e reflete sobre inúmeros aspectos e dimensões do conhecimento humano, tais como Cultura, História, Estética, Política, Filosofia, Comunicação e Estudos da Linguagem.

$\mathrm{O}$ resultado desse primeiro contato, ainda na graduação, foi o meu Trabalho de Conclusão de Curso, intitulado Literary Translation - an intersection between Theoretical Translation Studies and Descriptive Translation Studies. Minha abordagem buscou localizar a Tradução Literária nesse campo de estudos e descrever os elementos presentes no processo de tradução, sendo eles: linguagem, texto, signo e estética - a partir da análise das traduções para o texto dramático O Beijo no Asfalto, de Nelson Rodrigues, para Língua Inglesa, Cinema e Graphic Novel.

Mesmo em Letras, eu já estava em contato com o Teatro tanto na prática de atriz amadora, quanto no curso Técnico de Formação em Ator da Escola de Teatro e Dança da Universidade Federal do Pará (ETDUFPA), com andamento na mesma época. Dessa maneira, a escolha por um texto de literatura dramática, além de unir as duas áreas, foi o começo de um caminho de pesquisa sempre voltado à inter-relação de linguagens na experiência artística, em que tenho me fundamentado, sobretudo, na Filosofia da Arte, e tido como ponto de vista, o Ensino e Aprendizagem.

Através da análise de $O$ Beijo no Asfalto comecei a pensar que talvez o processo que melhor evidencia e proporciona a inter-relação de linguagens é a Tradução. Isso se dá exatamente por ela propor o deslocamento, a transferência, a transmutação e transcriação de textos, entre as mais diferentes linguagens -- e não como se pensou por muito tempo, sendo somente uma operação entre línguas, idiomas. A essa operação, se dá o nome de Tradução Intersemiótica. 
A origem do termo tem uma justificativa linguística, pois grande parte do escopo de autores que tratam do tema está nos Estados Unidos, o que os faz utilizar sempre a palavra language. Isso para nós, de língua portuguesa, resulta em uma ambiguidade (language = língua e linguagem). Por isso, opto pelo uso do termo sistema de signos, assim quando for necessário, falaremos de sistemas de signos verbais (língua/idoma), não verbais (por exemplo: artes plásticas, cinema) e híbridos (por exemplo, o teatro).

Com a pós-graduação em Artes Cênicas optei por prosseguir meus estudos dando continuidade à pesquisa em inter-relação de linguagens, pela Tradução Intersemiótica, estabelecendo um recorte na experiência prática do Artista Teatral.

No campo da Arte Teatral, encontrei na Dramaturgia a possibilidade de interação de linguagens, e isto se aplica tanto à dramaturgia textual quanto à dramaturgia cênica. É importante compreender que nos dois tipos de dramaturgia a que me refiro pode acontecer a inter-relação de linguagens seja por um dialogismo empregado na primeira, seja pela complexa composição sígnica da segunda.

Nessa abordagem de Dramaturgia, a inter-relação de linguagens aparece em função de o próprio signo teatral ser de origem múltipla: o corpo, a voz, a palavra, a luz, o som, a cor, os objetos - enfim, um conjunto de signos cênicos que em ação compõem diferentes camadas na cena, que possuem sistemas próprios e que conferem diferentes qualidades na encenação. Deste amplo universo de possibilidades, fiz um recorte para o trabalho do ator, buscando compreender como se dá o processo criativo que o ator vivencia em função da inter-relação de linguagens, ou seja, quando ele experimenta a Tradução Intersemiótica como ferramenta de criação.

Pedagogicamente, procurei elaborar, aplicar e descrever procedimentos e alguns exercícios para que o ator aproxime a linguagem teatral de outros sistemas de signos. Como resultado, eu esperava que o ator criasse uma dramaturgia (ações físicas e ficção), a partir de textos não dramáticos, e a encenasse. Assim, chegamos ao projeto definitivo e tema dessa dissertação: 


\section{Tradução Intersemiótica na elaboração da Dramaturgia do Ator: Pedagogia e Encenação.}

Para por a Tradução Intersemiótica (PLAZA, 87) em experimentação, escolhi dois sistemas de signos: Artes Plásticas e Cinema. A opção por esses sistemas está na proposição de Adolph Appia em A obra de arte viva (1921).

Havia, na época do autor, uma ideia corrente de que a Arte Dramática seria uma reunião harmônica de todas as outras artes. Ao analisar esta ideia, Appia descreve por quais princípios e elementos as outras artes se aproximam da Arte Dramática e afirma que o movimento é o princípio diretor e conciliatório para fazer convergir todas as formas de arte para a Arte Dramática. No movimento, Appia acredita haver a fusão do tempo e do espaço, sendo esta indispensável para a construção da harmonia cênica. A partir de sua leitura, podemos categorizar: Artes do Tempo (Música, Literatura), Artes do Espaço: (Artes Plásticas, Arquitetura) Artes do Tempo-Espaço: (Cinema) e Artes Performáticas (Dança e Teatro).

As Artes Plásticas, mais especificamente a pintura, foram escolhidas devido ao desafio que seria conferir mobilidade ao estático. $\mathrm{O}$ acréscimo do Cinema ocorreu exatamente pelo oposto, ou seja, pareceu-me um desafio experimentar a tradução intersemiótica de um sistema, que já tem tempoespaço e mobilidade, sem recorrer ao mimetismo -- além do fato de o cinema ser um campo artístico muito extenso e significativo tanto em produção quanto em referência simbólica para se estudar.

Há, no entanto, uma distinção importante a se fazer entre as investigações de Appia e meu projeto de Pedagogia e Encenação. Ele dedicouse na A Obra de Arte Viva em encontrar uma síntese e descrever os elementos que compõem a reunião harmoniosa da Arte Dramática, ao passo que eu parto desses elementos descritos por ele para utilizá-los em outra metodologia. Isto é, Appia buscou a decupagem da linguagem teatral e mostrou o que há nela de outras linguagens, eu busco uma igualdade de diálogo entre o sistema teatral e os outros sistemas. 
Meu recorte sobre as linguagens é mais didático do que fixo. Acredito que a Intersemiose ${ }^{1}$ é igualmente potente com outros sistemas. A própria Semiótica, nos extensivos estudos de Charles S. Pierce e de seus seguidores, já nos deu as ferramentas para análise, articulação e até mesmo formatação de uma linguagem e seus códigos, de forma que, todos esses sistemas podem dialogar com o Teatro. Em suma, as preocupações de Appia parecem ter residido na compreensão da Arte Dramática como linguagem múltipla em si um sistema de signos diversos. A mim, interessa agora compreender como esse sistema se relaciona, dialoga, com outros.

O sistema de signos do teatro já tem sua própria dinâmica, e a tradução é mais uma forma de acessar, de (des)construir, de desvelar um texto. Em qualquer outro processo de tradução, as linguagens escolhidas não são uma prioridade, não precisam ser fixadas. Dependendo do aspecto a ser investigado, elas variam. Elas mudam porque o que conta é a apropriação do texto e criação de um novo texto, pois a tradução é transformação.

No campo da Arte Teatral, meu principal objeto é a qualidade do processo criativo através da Tradução Intersemiótica. Coordenar um processo como esse é um desafio e requer uma metodologia. Assim, fiz mais um recorte na pesquisa, nesse caso, para o processo de criação da dramaturgia do ator.

Tenho chamado de dramaturgia do ator a construção cênica de ação e ficção pelo artista teatral. Embora Eugene Barba, autor do tempo, utilize-o em função do atuante, é salutar lembrar que a tradução intersemiótica pode ser experimentada em qualquer função criativa do processo cênico. Ação e ficção foram abordadas como unidades do drama.

Pedagogicamente, eu elaborei procedimentos e alguns exercícios ${ }^{2}$ que visavam instrumentalizar o artista para ler - decodificar - os textos a serem traduzidos. É importante compreender a palavra texto, a partir dos estudos de Roland Barthes em Da obra ao texto onde ele faz uma distinção radical entre a

\footnotetext{
${ }^{1}$ Ação dos signos.

${ }^{2}$ Sobre os procedimentos e exercícios, eles podem sempre ser usados tendo em vista tanto o ensino e aprendizagem quanto a criação, porém eles se diferenciam na medida em que os procedimentos são usados prioritariamente para introduzir, reconhecer e experimentar; já os exercícios são usados para a apropriação e fixar.
} 
dita obra de arte e a malha do texto - a tecedura - na qual a primeira seria estática, concreta e até "encontrada em bibliotecas e estantes" e a segunda seria fluída, um discurso que se articula e se revela na linguagem.

Os resultados de encenação sobre os quais também dissertarei aqui são frutos da experiência em dramaturgia do ator, onde obtivemos dois resultados espetaculares. Na verdade, trata-se de dois exercícios cênicos. O primeiro, "Efêmea", é fruto de um processo de pesquisa teórico e prática ocorrido no período de junho a outubro de 2011, seu objetivo principal era experimentar a tradução intersemiótica pela via da relação norma e forma, proposta pelo autor Julio Plaza; o segundo, “...E fêmea”, aconteceu entre janeiro e março de 2012 e teve como principal mote, de tradução e apropriação, a análise do discurso, proposta do Mikhail Bakhtin. Assim, focamos separadamente nos dois tipos de dramaturgia, cênica e textual, respectivamente. Parte do processo foi documentando em blog de internet, onde há textos sobre os principais temas desenvolvidos na pesquisa: www.dramaturgiadoator.wordpress.com.

A dissertação é composta de seis capítulos principais, sendo Introdução o primeiro. No segundo, Tradução Intersemiótica, falo conceitualmente sobre no que consiste esse tipo de tradução a partir dos estudos de Júlio Plaza, Roman Jakobson e James Holmes. No terceiro capítulo, intitulado Crítica Genética, apresento a metodologia de pesquisa que utilizei para compreender o processo tão rico e complexo que vivemos ao longo desses meses. Nele, baseio-me nos estudos da Prof ${ }^{\mathrm{a}}$ Dr $^{\mathrm{a}}$ Cecília Almeida Salles, autora de diversos livros na área e que coordena o Centro de Estudos de Crítica Genética da PUC/SP. Há dois subitens: Obras como Processo - onde centro meu olhar, sobretudo no processo vivido pelos artistas ao experimentar a tradução intersemiótica e não no resultado em si - e Fundamentos, onde exponho os fundamentos dessa metodologia.

Redes da Criação, o quarto e maior capítulo, também dialoga com as teorias da autora. Cecília Almeida Salles propõe pensarmos na criação em rede, identificando onde estão os nós, ou seja, onde estão as recorrências que amaram e sustentam o processo. Aqui, esses nós aparecem em três momentos, ou três 
tipos de redes. São eles: os Estudos Teóricos, as Oficinas Pedagógicas e a Encenação, devidamente detalhadas com seus subitens.

No quinto capítulo, Sistêmicas do Olhar, mudamos o foco do processo para a resultante. Assim, analiso os dois exercícios cênicos a partir da tipologia das traduções proposta por Plaza como Tradução Icônica, Tradução Indicial e Tradução Simbólica. Portanto, é como se eu estivesse propondo formas de olhar nossos resultados.

Gostaria de ressaltar a respeito da Pedagogia e da Encenação que o importante, nesse processo, foi a nossa tentativa de exercitar a tradução. E foi por essa tentativa que nós descobrimos o que era o necessário, e como abordar os textos. Isso não quer dizer que nosso resultado seja a melhor tradução possível - ela é uma possibilidade de tradução, um exemplo -- muito menos que tenhamos esgotado o número de leituras. Contudo, foi pela prática que nós descobrimos uma abordagem teórica para os estudos da Tradução, ao qual tanto me afilio.

Desde as Oficinas Pedagógicas, não era minha intenção 'ensinar' como traduzir, ou como olhar, mas era dar algumas ferramentas previamente estudadas para entender como as atrizes e, mais tarde outro ator, as usavam se e quando as usavam. Às vezes, percebi que outras ferramentas eram necessárias - daí a transição entre as redes, tendo que voltar aos Estudos Teóricos e encontrar outras opções de Encenação. E, assim, fomos juntos buscando compreender como nos aproximar dessas obras e como trazê-las para nossos processos criativos. Estudantes da Escola de Arte Dramática (EAD), atrizes graduadas e/ou com anos de prática profissional, atores e músicos foram nossos grandes parceiros nesse processo.

Para concluir esse capítulo, indico que minha pesquisa é destinada ao campo da Formação do Artista Teatral e procura encarar a elaboração da dramaturgia do ator via tradução intersemiótica como uma alternativa de abordagem na formação do ator, pois entendo que esse processo se desenvolve fora do escopo da formação tradicional. Há também uma demanda, um interesse grande dos alunos, dos artistas em inter-relação de linguagens. Em 
verdade, experimentos assim têm sido feitos, porém não há até agora uma descrição e uma pedagogia desse processo para que seus princípios operantes sejam localizados e para que os atores o experimentem com maior consciência, portanto, maior liberdade.

Com a Tradução Intersemiótica espero comprovar que o ator pode e deve atentar-se para a busca da Teatralidade que não está apenas no texto dramático, assim como, também entendê-la como um caráter, maior que a sua própria linguagem. Desse modo, o ator encontrará em qualquer representação simbólica, em que ele identifique teatralidade, um motivo, um estímulo, um discurso para a articulação de um novo texto, de sua dramaturgia.

\section{TRADUÇÃO INTERSEMIÓTICA}

O registro mais antigo do termo Tradução Intersemiótica com que entrei em contato está no texto On Linguistic Aspect of Translation do pensador russo Roman Jakobson, em que ele trata sobre os três tipos de interpretação e tradução que um signo pode ter: Intralingual, Interlingual e Intersemiótica.

Também conhecida como Transmutação, a tradução intersemiótica foi, por ele, definida como "uma interpretação de signos verbais por meio de signos de um sistema não verbal" (JAKOBSON, 2000, p.114). Neste mesmo texto só há mais outra referência à intersemiótica, quando o autor exemplifica: "da arte verbal para a música, dança, cinema e pintura”. Sugiro reformular da seguinte maneira: A Tradução Intersemiótica é a transposição de um texto entre sistemas de signos diferentes - sem que esse texto de partida esteja obrigatoriamente em signos verbais.

Considero que essa seja a principal alteração que deve ser feita quanto à proposição de Jakobson. No mais, não há restrições quanto às linguagens, isto é, todos os sistemas de signos podem participar da transmutação, sendo que isso contempla sistemas para além dos classicamente considerados artísticos.

Mais tarde, no Brasil, por volta da década de oitenta, os primeiros apontamentos de Jakobson sobre a intersemiótica foram retomados por Júlio 
Plaza que publicou, como resultado de sua tese de doutoramento, o livro Tradução Intersemiótica (1987). Nesse estudo inédito, Plaza se apóia, sobretudo, em outros artistas pensadores que abriram caminho para uma investigação e abordagem ao problema da tradução por um viés que não o linguístico. Podemos citar: Walter Benjamin, Paul Valéry, Ezra Pound, Octavio Paz, Jorge Luís Borges e especialmente Haroldo de Campos, cuja influência em seu texto é notável. Dessa forma, Plaza preenche parte importante da lacuna teórica sobre a tradução intersemiótica, modificando a posição de interpretado para interpretante a que o sistema de signo não verbal estava relegado.

Metodologicamente, o trabalho elaborado por Júlio Plaza é uma síntese de práticas artísticas ${ }^{3}$, ora de sua própria autoria, ora a partir de seus trabalhos interdisciplinares com outros artistas. Além da contribuição dos artistas pensadores, sua síntese foi também produto de uma reflexão sobre a teoria semiótica de Charles Sanders Pierce (1839-1914), que eu também retomo nesse trabalho, porém mediante uma leitura independente.

Ao centralizar-se na linguagem visual, Plaza não escreveu exatamente sobre Teatro, ele apontou, no entanto, para a Tradução Intersemiótica como Intercurso dos Sentidos.

Semelhantemente ao autor, é pela experimentação prática que apoio minhas investigações teóricas. No caso, a minha foi centrada na experiência cênica e vivida ao longo do processo em diferentes etapas. Às vezes, experimentávamos em função de comprovar e até mesmo ilustrar aspectos teóricos que estavam sendo estudados. Outras vezes, da prática surgiam fenômenos surpreendentes que impulsionaram a reorganização do conhecimento e a elaboração de novos procedimentos que dessem conta das necessidades criativas, e que levaram a conclusões próprias ao Teatro e próprias à qualidade da relação entre Artes Cênicas, Plásticas e Cinema, quando em transmutação.

\footnotetext{
${ }^{3}$ Práticas artísticas com diversas linguagens e meios - multi-meios e intermeios - cujo foco era a linguagem visual.
} 
Finalmente, muito embora Plaza não trate diretamente de um projeto didático ou uma sistematização pedagógica em seu livro, a mudança proposta por ele sobre o entendimento do sistema não verbal introduziu e estabeleceu, por si só, bases importantes para mudanças no ensino das Artes e da Comunicação. Teoricamente, ele rompe definitivamente com as questões ideológicas da 'fidelidade' na Tradução, tendo em vista a impossibilidade de um signo substituir completamente o outro, podendo no máximo apontar para ele. Plaza também enfatiza a não hierarquização entre texto, linguagens e suportes; originais e traduzidos; passado e presente.

Ele concebe a Tradução Intersemiótica como prática crítico-criativa e meta-criação. Abre espaço para o diálogo entre os signos e a re-escritura histórica. Esse novo espaço nos faz pensar que a tradução intersemiótica depende muito mais das qualidades criativas e do repertório do artista tradutor do que de uma forma específica de proceder, o que é uma verdade para qualquer indivíduo confrontando-se com os signos, sejam eles estéticos ou não. Porém, é no tratamento de Plaza para com a transposição de normas e formas que se faz necessária uma pedagogia, uma instrumentalização de leitura, decodificação e reescrita. Isso implica em pensar radicalmente a tradução como meio de produção artística, para formular procedimentos de aproximação do artista-tradutor com seu próprio repertório simbólico e criativo.

\section{$\underline{\text { Transmutação }}$}

Vimos que a Tradução Intersemiótica pode ser entendida como um estudo e ao mesmo tempo como prática artística, isto é, não se trata apenas de uma ferramenta para a análise e compreensão do fenômeno da Tradução, mas também um meio de produção criativa.

Ainda assim, quando se fala da prática de tradução, é comum recairmos em exemplos de tradução intralingual e interlingual ${ }^{4}$. Isso acontece porque a

\footnotetext{
${ }^{4}$ Intralingual é a tradução cuja transferência se dá no mesmo sistema verbal, ou seja, quando, por exemplo, substituo uma palavra por outra - as sinonímias, isto é, dentro da mesma
} 
maior parte das teorias existentes dá conta desses dois tipos. E embora cheguem a apontar para, não abordam questões específicas da Tradução Intersemiótica muito menos as formas como ela opera. Nosso avanço está em conhecer esta operação, a qual se dá o nome de transmutação.

Há três formas pelas quais a transmutação opera. São elas: (1) transposição criativa, (2) transcriação e (3) convergência textual.

A primeira, a transposição criativa, é a que Jakobson e Plaza acreditam ser a única forma possível de tradução intersemiótica: “Tradução e criação são operações gêmeas. De um lado, [...] a tradução é indistinguível muitas vezes da criação; de outro, há um incessante refluxo entre as duas, uma contínua e mútua fecundação" (PAZ, 1987, p. 26).

A transposição criativa está em produzir com meios diferentes, efeitos análogos. Ou seja, transcodificar criativamente um texto em outro, sabendo que esse texto são códigos em uma linguagem.

Quando Octavio Paz diz que são operações gêmeas, ele quer dizer que tanto criar um "texto original" quanto um "texto traduzido" implica nessa codificação - no caso da tradução, a trans(codificação). A prática artística, estética, nos desperta uma consciência que é a própria consciência da linguagem, uma reflexão sobre as escolhas e os arranjos feitos e as qualidades encontradas. Essa consciência estará ativa nos dois momentos, na elaboração do "texto original" e na do "texto traduzido".

Transpor criativamente é lidar também com a ambiguidade poética, característica intrínseca, inalienável, do objeto estético em qualquer código.

A ambiguidade poética está no objeto estético porque o objeto estético revela-se na função poética da linguagem ${ }^{5}$. Foi Jakobson que desvendou os procedimentos que engendram poeticidade e plurissignificância nas mensagens verbais e não verbais. A supremacia dessa função sobre as outras torna

língua/linguagem. Interlingual é a transferência entre sistemas verbais diferentes, ou seja, quando traduzo um texto de um idioma para outro, por exemplo, do inglês para o português.

${ }^{5}$ São seis as funções da linguagem: Referencial, Apelativa, Fática, Expressiva, Metalingüística e Poética. Esta última, também conhecida como Estética, é aquela que põe em evidencia a forma da mensagem. Trata-se do como ao invés do o que. 
ambígua a capacidade referencial das linguagens e empresta um tom de imprecisão à mensagem, criando uma tendência para a auto-referência, isto é, a linguagem apontando para seu próprio processo construtivo. Traduzir na função poética da linguagem é projetar princípios de equivalência dos eixos de seleção e de combinação, de modo que a equivalência resida também na ambiguidade.

Por conta da ambiguidade poética, muitos teóricos escreveram sobre a intraduzibilidade do signo-estético. Haroldo de Campos aponta para aquilo que é possível em termos de tradução poética e nos fazer ver uma questão, por natureza, intersemiótica: traduzir a forma. Transcriar, portanto.

A transcriação, segunda forma de operar, implica a um regresso ao original, onde estão as chaves, as leis, que determinam a traduzibilidade de um texto. Assim, da mesma maneira que: "nenhum dado do conhecimento pode ser ou ter pretensões a ser objetivo quando se contenta em reproduzir o real" diz Benjamim, “assim também nenhuma tradução será viável se aspirar essencialmente a ser uma reprodução parecida ou semelhante ao original" (BENJAMIN, 1923, apud PLAZA, 1987, p. 29).

É importante saber que quando Campos e Benjamin escreveram sobre a tradução poética referiam-se à tradução da forma "poema" ou de literatura em geral. Ainda assim acredito ser possível considerar tanto a tradução poética quanto a própria função poética da linguagem como independentes da forma poema, ou seja, a poeticidade é um caráter comum às artes, assim pode estar presente tanto em um poema, quanto em pinturas e filmes ou em qualquer outro tipo de texto.

O que já é válido para a tradução poética como forma, acentua-se mais ainda para a tradução intersemiótica. Criar nesse tipo de tradução determina escolher dentro de um sistema de signos que é estranho ao sistema original, por exemplo, quando criamos uma peça de teatro a partir de signos plásticos. Assim também, ler e traduzir o texto original é fazer escolhas cujos códigos diferem daqueles que serão usados para criar, outro exemplo: quando escolho entre os 
códigos cinematográficos aqueles que mais me interessam para traduzir em cena.

São os eixos de escolhas e combinações que determinam uma dinâmica na construção da tradução e fazem surgir "a tradução do traduzido", intensificando as diferenças "estruturalmente avessa à ideologia da fidelidade" (PAZ, 1987, p.30).

Pensando em Teatro, podemos entender mais claramente a terceira forma da transmutação: a convergência textual. É da natureza da transmutação por em jogo significados distintos que buscam organização e organicidade em torno do projeto estético.

Do ponto de vista da transmutação, a convergência textual acontece quando relacionamos os dois sistemas - e seus códigos - em função de transplantar o discurso que está presente no primeiro. Tendo esse discurso sido identificado e compreendido em suas relações intracódigos, é possível iniciar a operação.

\section{CRÍTICA GENÉTICA}

O estudo da Crítica Genética foi integrado ao projeto de pesquisa enquanto eu me dedicava à escrita do Relatório de Qualificação. Durante essa etapa percebi o quanto eu estava centrada em entender e explicar os conceitos usados na prática da tradução, ao passo que eu pouco me referia ao processo de criação em si. E, no entanto, essa havia sido a fase de maior produtividade, facilmente identificável seja pelas inúmeras anotações e registros em áudio e vídeo, seja pelas necessidades e caminhos a que o processo foi nos conduzindo durante a pesquisa.

Expus essa questão no exame de qualificação ${ }^{6}$ e tive uma recepção positiva dos examinadores, que me orientaram a fazer esse recorte sobre meu projeto. Assim, o processo de criação por tradução intersemiótica tornou-se meu objeto de pesquisa, análise e estudo. E a Crítica Genética, tornou-se a minha abordagem metodológica.

6 Em 20 de outubro de 2011. Eram os examinadores: Prof. ${ }^{\circ}$ Dr. ${ }^{\circ}$ Armando Sérgio da Silva (orientador), Prof. ${ }^{o}$ Dr. ${ }^{o}$ Eduardo T. Coutinho e Prof. ${ }^{a}$ Dr. ${ }^{a}$ Cecília Almeida Salles. 
Os estudos em Crítica Genética, os chamados estudos genéticos, tiveram seu início no final da década de sessenta, no Centre National de la Recherche Scientifique, na França. No Brasil, ela foi introduzida por Philippe Willemart, responsável pelo I Colóquio de Crítica Textual: o Manuscrito Moderno e as Edições, na Universidade de São Paulo, em 1985.

Em 1992, com a publicação da primeira edição da Introdução aos Estudos Genéticos, de Cecília Almeida Salles, já havia apontamentos que vislumbram a ampliação do campo dos estudos genéticos para além dos manuscritos literários. Quando a Crítica Genética surgiu, o principal objetivo era "melhor compreender o processo de criação, a partir dos registros desse seu percurso deixados pelo artista" (SALLES, 2008, p. 20), porém ainda se falava apenas em registros literários.

Historicamente, podemos dizer que a Crítica Genética chega ao século XXI, conquistando sua transdisciplinariedade, atravessando fronteiras de artes, de gêneros e abordagens teóricas. Dessa forma, aqueles que são interessados pelo processo criativo, de acordo com a abordagem genética, "fazem dessas pegadas, que o artista deixa de seu processo, uma forma de se aproximar do ato criador e, assim, conhecer melhor os mecanismos construtores das obras artísticas." (SALLES, 2008, p. 21) - portanto uma construção intelectual do crítico sobre a construção intelectual do artista.

\subsection{FUNDAMENTOS METODOLÓGICOS}

Gostaria de expor quais são os fundamentos metodológicos que irei utilizar para abordar os processos criativos que nos levaram aos exercícios cênicos Efêmea e "...E fêmea", ao longo da pesquisa de mestrado.

A partir da leitura de Crítica Genética: Fundamentos dos estudos genéticos sobre o processo de criação artística ${ }^{7}$, eu selecionei alguns aspectos apontados no livro que melhor dialogam com minha pesquisa e que mais nos ajudarão a compreender o processo criativo desenvolvido, por meio de seus registros.

7 SALLES, Cecília A. EDUC, São Paulo: 2008. 
Esses aspectos são: (1) Constituição do Dossiê Genético, (2) Observação do Material e (3) Abordagem Teórica. Quando me refiro a fundamentos quero dizer, sobretudo, da importância desses três aspectos na metodologia, isto é, o fato de serem etapas fundamentais para estabelecer a pesquisa. A ordem em que os coloquei explicita a própria ordem com que irei proceder perante os registros.

Também conhecidos por documentos de processo, os registros que são feitos ao longo da pesquisa são o corpus e precisam ser organizados. Para elaborar meu dossiê genético, primeiramente, agrupei todos os dados de acordo com o suporte e a etapa do processo a que se relacionavam. A princípio eu não excluí nenhum registro, pois temia desfazer-me de alguma pista que poderia vir a ser importante mais adiante, ainda que no momento não me parecesse. Quando o processo criativo é longo e há muitas pessoas envolvidas - como no caso da criação cênica - é comum que muitas decisões e mudanças se dêem sem deixar rastros, por isso fiz a opção de não descartar nenhum documento, já que "cada fragmento dos documentos é uma peça de uma rede de caráter intelectual" (SALLES, 2008, p. 58).

Para que fique mais claro o que é a Constituição do Dossiê Genético:

O trabalho do crítico genético começa com a constituição ou organização de seu objeto científico. Sua tarefa inicia-se, portanto, numa série de etapas que tem o objetivo de tornar os documentos que ele tem em mãos legíveis. Estou me referindo à elaboração do dossiê dos documentos de processo. (SALLES, p.62)

Quando desloquei meu foco dos conceitos envolvidos na prática da tradução intersemiótica para o processo criativo em si, o que fiz foi alterar meu objeto científico. Assim, deixei de me preocupar apenas em aplicar na cena os conceitos de tradução, e passei a incentivar a prática espontânea da mesma mas, agora, estaria observando atentamente como esse processo criativo dialoga com a teoria e traz contribuições para o que se tem escrito sobre o assunto.

Contudo, é imprescindível que eu mencione que essa alteração só foi possível quando passei a olhar diferente para os documentos de processo. O que antes eram apenas estratégias para não precisar anotar constantemente ao longo 
dos ensaios, isto é, uma ajuda para a memória, passou a ser parte de uma poética que aos poucos foi se revelando.

Esse revelar-se tem a ver com dois pontos essenciais da elaboração do dossiê. O primeiro está em tornar os documentos legíveis, pois isso contribui para que o crítico possa compreender e compartilhar o conteúdo intelectual dos mesmos. O segundo, por sua vez, reside no recorte que o crítico pretende fazer, pois é preciso que ele saiba e estabeleça previamente o que procurar neles. Cecília Salles acrescenta que além do que procuramos, o recorte deve estar associado "àquilo que somos capazes de ver". (2008, p. 63)

Fiz o recorte sobre os documentos que registraram a elaboração da dramaturgia do ator, pelas atrizes envolvidas na pesquisa. E nelas busquei em que momentos e de que forma se estabeleceu uma textura intersemiótica nesse processo de criação. A intersemiose é o que, neste momento, proponho vermos.

Com a constituição do dossiê genético gera-se um prototexto8: “um novo texto, formado por esses materiais, que colocam em evidência os sistemas teóricos e lógicos que o organizam" (SALLES, p. 62). Entretanto, é importante saber que o prototexto "não existe em nenhum lugar fora do discurso crítico que o produz; nasce, portanto, da competência do crítico genético que se encarrega de estabelecê-lo e [...] explorá-lo em um processo analítico e interpretativo" (p.62).

A Observação do Material é o passo seguinte:

Esse trabalho inicial com o dossiê exige uma fase de identificação da combinatória de deslocamentos, substituições, expansões e retrações que os documentos manifestam, a fim de assinalar e sistematizar o conjunto de operações genéticas. (SALLES, 2008, p. 68)

Observar as operações genéticas é o que pôde garantir a identificação das recorrências no modo de agir das atrizes e, por vez, do encenador. Para isso, a autora afirma que o tempo de convivência do crítico com os documentos é de extrema importância. Acredito que quanto maior for esse tempo, proporcional pode vir a ser o detalhamento nas anotações sobre os registros.

\footnotetext{
8 Termo introduzido em 1977, por Jean-Bellemin-Noel. (SALLES, 2008, p.62)
} 
Salles também propõe duas perguntas que norteiam essa relação: $O$ que esse material me oferece sobre o processo criativo do artista estudado? Que aspectos de seu processo criativo estão aqui evidenciados? Ela explica que responder a essas questões ajuda a estabelecer um recorte sobre os documentos. Creio que essas perguntas possam ser levantadas mesmo quando já se tem um recorte préestabelecido - como foi o caso dessa pesquisa, em que os artistas iniciaram o processo já tendo em vista que elaboraria uma dramaturgia do ator pela tradução intersemiótica - pois mesmo tendo um pré-recorte, o crítico precisa estar aberto e atento a tudo o que o material oferece, podendo até se surpreender.

O crítico genético não só narra a história das criações. Os vestígios deixados por artistas oferecem meios para captar fragmentos do funcionamento do pensamento criativo; oferecem uma sequência de gestos advindos da mão criadora e experenciados, de forma concreta, pelo crítico. Gestos que se repetem e deixam aflorar teorias sobre o ato criador. (SALLES, 2008, p. 69)

Para que as teorias aflorem, o crítico busca explicações para o processo criativo. Nessa perspectiva, nem narrar nem descrever são suficientes para ele, que precisa enfrentar a complexidade das informações que obteve e, assim, poderá sistematizar os dados, localizando as recorrência e periodicidades que interpretará: “O interesse não está em cada forma, mas no modo como se dá a transformação de uma forma em outra." (SALLES, 2008, p. 69)

O mesmo aconteceu quando me deparei com os diversos vídeos dos ensaios, áudios de depoimento e observei quantas possibilidades de ações e ficções foram propostas, quantos gestos se modificaram e, ainda, cenas inteiras que pareciam ser do agrado de todos os envolvidos foram completamente excluídas. Essas eram transformações e mudanças recorrentes que pude notar, porém para interpretá-las eu precisarei estabelecer uma Abordagem Teórica, foi assim que as três operações da transmutação $0^{9}$ tornaram-se hipóteses a testar, como veremos nos capítulos 4.1 Oficinas Pedagógicas e 4.2 Encenação, quando tratarmos especificamente dos exercícios cênicos Efêmea e "...E fêmea"

\footnotetext{
${ }^{9}$ Transposição criativa, Transcriação e Convergência textual (ver cap. 2 - Tradução Intersemiótica)
} 
Sobre a transmutação, como Abordagem Teórica, eu devo esclarecer que a identificação e a escolha desses aspectos só se deram após meus contatos com os documentos, já que, embora a teoria da tradução intersemiótica tivesse sido desde o início dos meus estudos a base da pesquisa, eu havia a abordado de uma forma geral, isto é, busquei uma compreensão ampla do que Julio Plaza propunha. Devido aos registros é que fui levada às operações.

De acordo com a autora, proceder dessa forma é justificado por:

\begin{abstract}
Os instrumentais teóricos devem ser convocados de acordo com as necessidades do andamento das reflexões, para que os documentos dos artistas não se transformem em meras ilustrações das teorias. Nesses casos, os conceitos perderiam seu poder heurístico, ou seja, a pesquisa ofereceria muito pouco retorno no que diz respeito a descobertas sobre o ator criador. (SALLES, p. 70)
\end{abstract}

Agora, parece-me muito mais fenomenológico agir dessa maneira, pois a própria experiência prática convoca quais teorias devemos buscar, mesmo que estas estejam fora do escopo inicial que tínhamos - isto porque por detrás de "toda ação criadora há uma teoria implícita" (SALLES, 2008, p. 124).

Os documentos implicam também em um ir e vir de abordagens teóricas, pois o registro expõe um tempo que não é o tempo linear, mais que isso, é o tempo do fluxo da criação. E nesse fluxo, o artista respeita apenas a necessidade de seu processo criativo.

\title{
2.1. OBRA COMO PROCESSO
}

Quando falamos de obras que são processo, dizemos de uma prática que se estabelece de antemão e que, depois, solicita ao pesquisador buscar conhecimento teórico para compreender o que se deu e como isso pode ser colocado em perspectiva. Dessa forma, como já dito anteriormente, minha intenção deixou de ser exercitar a teoria de Júlio Plaza, para então, incentivar o exercício livre da tradução intersemiótica e depois pôr esse resultado em diálogo com a teoria do autor citado. 
Perceber onde há ponto de contatos, onde há a recorrência e confirmação de aspectos já mencionados e onde nossa experiência requer nova compreensão e abordagem é fazer de nossa obra principal não os resultados cênicos, mas o processo em si - sobretudo por que é ele que aponta quais necessidades começam a surgir com a prática, pois "a obra não está só em cada uma das versões, mas também na relação que é estabelecida entre essas diferentes versões", afirma a autora Cecília A. Salles em Redes da Criação (p. 163.).

A escolha pela Crítica Genética, como metodologia de compreensão da pesquisa, nos faz acompanhar e entender o porquê das atrizes e do encenador optar por esta ou aquela versão de seu trabalho e como eles acreditavam que isso justifica o objetivo prévio de elaborar uma dramaturgia do ator através da tradução intersemiótica.

\section{AS REDES DA PESQUISA}

Há nesse capítulo o esforço principal de organização do processo vivido, pois para comunicá-lo é preciso troná-lo legível. Cada um dos subtópicos são redes. Podemos afirmar isso, pois eles aconteceram sem respeitar uma linearidade fixa, na qual foram se estabelecendo relações que agora eu também tento abordar pelo ponto de vista relacional.

Para isso, apoiei-me nos conceitos de Criação em Rede, também de autoria da professora Cecília Almeida Salles. Neste conceito: "O que interessa é o movimento do processo, bem como as relações estabelecidas entre os documentos - o processo como mobilidade e como rede relacional". (p. 11)

Durante o processo percebi quatro grandes redes: Estudos Teóricos, Oficinas Pedagógicas, Encenação e Dramaturgia do Ator. É, sem dúvida, uma separação didática, pois noto que essas redes também se relacionam entre si. Mas antes disso, por que chamar esses quatro momentos de redes?

Creio que a principal característica da rede, da forma como colocada por Salles, é a não linearidade, ou seja, uma malha cujas relações e conexões não podem ser compreendidas como um sistema no qual seus elementos estão 
dispostos como se derivassem uns dos outros, em uma só dimensão. A linearidade está geometricamente relacionada às linhas retas, o que se contrapõe diretamente à imagem que temos de rede.

No livro da professora, já citado no parágrafo inicial, podemos notar que há cinco conceitos que compõe a criação em rede, são eles: (1) Dinamicidade, (2) Inacabamento, (3) Rede, (4) Interação e (5) Transformação.

Observemos agora as redes Estudos Teóricos, Oficinas Pedagógicas, Encenação e Dramaturgia do Ator.

\subsection{ESTUDOS TEÓRICOS}

Uma das redes que se formou foi a de Estudos Teóricos. Podemos dizer que foi uma rede já que ela se constituiu, sobretudo, pela não linearidade. Abaixo segue um breve resumo sobre os principais estudos feitos e como eles se relacionaram com a pesquisa.

\section{a) Estudos da Tradução - James Holmes}

Ainda que estivéssemos pesquisando tradução intersemiótica e teatro, era preciso compreender como isso se encaixava no já elaborado escopo dos estudos da tradução, pois é uma área que já está estabelecida no campo acadêmico. Nós partimos do trabalho mais geral e abrangente sobre os Estudos da Tradução, de James Holmes.

Embora a prática de tradução seja estabelecida há muito tempo, o estudo deste campo foi desenvolvido como disciplina acadêmica apenas na segunda metade do século XX. Os primeiros escritos sobre Tradução começaram a partir da experiência prática de tradutores com base na necessidade de refletir sobre os problemas enfrentados quando traduzindo. Antes disso, a tradução foi por muito tempo só um elemento de Ensino e Aprendizagem de idiomas de Línguas Modernas.

Como disciplina acadêmica, a Tradução começou de fato nos últimos sessenta anos e é agora conhecida como Estudos da Tradução, devido ao teórico 
americano James S. Holmes. Em The Name and Nature of Translation Studies o autor se refere a então nascente disciplina como um "complexo de problemas agrupados em torno do fenômeno de traduzir e das traduções" (HOLMES, 2000, p. 173), para o qual ele afirma trata-se de um caso em que, inicialmente, o influxo de pesquisas, paradigmas e modelos falhou para produzir resultados suficientes, obrigando os pesquisadores a ficaram atentos de que seriam necessários novos métodos e abordagens para o problema da Tradução - tendo esta, avançado em meio a pesquisas investigativas de diversas áreas que levaram gradualmente ao estabelecimento de novos canais de comunicação e a um novo senso de interesses compartilhados. Dessa forma, o complexo de problemas possibilitou que estudiosos se identificassem com a emergente disciplina e buscassem legitimação para seus pontos de vista.

Quando Holmes iniciou seus estudos, o cenário acadêmico era bastante confuso, já que continha em si um caráter híbrido resultante da reunião de estudiosos dos mais diferentes campos. Assim, não havia um consenso nem quanto aos tipos de terminologias, modelos e métodos a serem testados e aplicados, e nem sobre o nome do novo campo. Após avaliar uma série de termos em inglês, francês e alemão, Holmes chegou à essencialidade da palavra 'estudos' por ela contemplar a disciplina como um campo de aprendizado e remover uma série de mal entendidos e confusões que termos como "arte", "trabalho", "teoria", "fundamentos", "princípios" e "ciência" traziam, muito embora o termo 'estudos' também apresente dificuldade - como, por exemplo, a tentativa de se derivar uma forma adjetiva.

$\mathrm{O}$ esforço que consistiu em encontrar um nome apropriado para a disciplina, revelava ao mesmo tempo, uma necessidade maior dos Estudos da Tradução: compreender sua própria natureza.

Considerando que a meta-reflexão é frequente no caso de uma nova disciplina, Holmes cita o alemão Werner Koller como um dos poucos a terem delineado-a mais aproximadamente: "Translation studies is to be understood as 
a collective and inclusive designation for all research activities taking the phenomena of translating and translation as their basis or focus" 10 .

Holmes conclui, então, que os Estudos da Tradução constituem-se em uma disciplina empírica por lidarem diretamente com o fenômeno em si. Ele elabora o mapa geral da disciplina sobre as áreas que a tradução recobre e as formas em que se manifesta. Sua descrição do conteúdo é discursiva. Para facilitar a apreensão, proponho a descrição do conteúdo, em mapa gráfico (Figura 1).

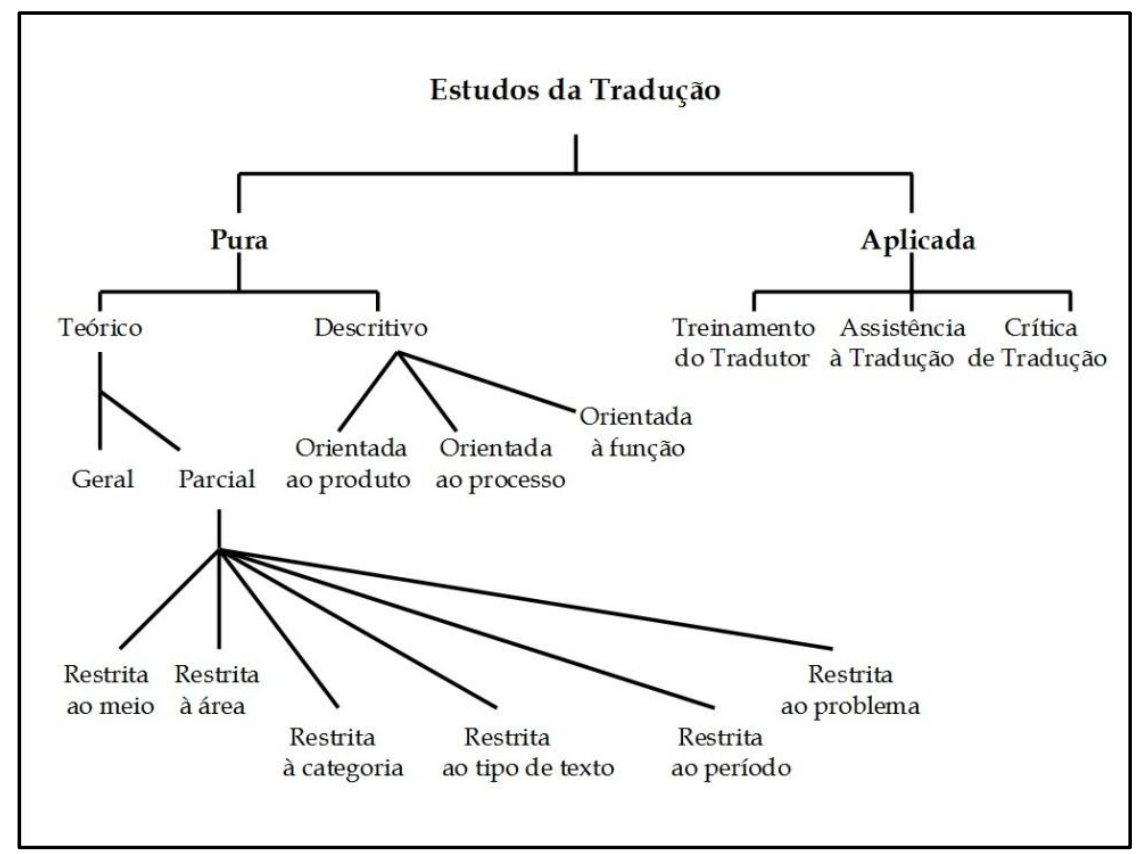

Figura 1: Mapa dos Estudos da Tradução (Fonte: da Autora)

Holmes divide a disciplina em duas áreas principais: estudos de tradução "pura" e estudos de tradução "aplicada". Os estudos de tradução "pura" tem o duplo objetivo de descrever os fenômenos de traduzir e da tradução como eles ocorrem (estudo descritivo da tradução) e desenvolver princípios gerais pelos quais esses fenômenos podem ser explicados e previstos (estudo teórico da tradução).

Os estudos teóricos de tradução - ETT - são divididos em teorias "gerais" e "parciais". Por "geral", Holmes está se referindo aqueles escritos que

10 Tradução minha: "Os estudos da Tradução devem ser entendidos como uma designação coletiva e inclusiva para todas as atividades de pesquisa que tomam o fenômeno da tradução e de traduzir como sua base ou foco". 
procuram descrever cada tipo de tradução e fazer generalizações que serão relevantes para a tradução como um todo. Um exemplo importante de teoria geral são os escritos de Roman Jackobson (1959) a cerca dos três tipos de Tradução: Intralingual, Interlingual e Intersemiótica (JAKOBSON, 1970, p. 36). Já com "parcial", diz-se do estudo restrito de acordo com a sua subdivisão em: meio (mídia), área, categoria, tipo de texto, período e problema. O exemplo de teoria parcial seria o estudo de Haroldo de Campos (1967) sobre a Tradução Poética, ou seja, restrita ao tipo de texto poema. (CAMPOS, 1967, p. 21-28). O outro ramo "puro" da investigação no mapa de Holmes são os estudos descritivos da tradução - EDT - em que há três focos de orientação: produto, função e processo.

Quanto à outra área - estudos da tradução 'aplicada' - Holmes diz ser a área que trata 'do uso', pois compreende a aplicação que se estende para além do limite da própria disciplina, caindo respectivamente nos aspectos de ensino e avaliação: treinamento, assistência, política e crítica.

Sabemos pelo contexto e corpus que Holmes escreveu prioritariamente sobre a tradução textual oral e escrita. Porém, isso não encerra a amplitude da estrutura que ele nos deixou, ao descrever os ramos de Tradução Pura e Aplicada em suas dimensões Históricas e Metodológicas. Holmes fala em language para falar de línguas e idiomas, mas acredito que, baseando-me na estrutura deixada pelo autor, seja possível pensar em uma tradução que contemple a language como linguagem, sistemas de signos, a Tradução Intersemiótica.

Assim, poderíamos pensar igualmente em um modelo de disciplina, estabelecendo e apontando novas particularidades quando necessário - é uma indicação dada pelo próprio autor, pois, tendo o Estudo da Tradução alcançado tal estágio em que se encontra, deve-se examinar o assunto em si. Ele nos diz que é hora de começar a meta-discussão.

Nessa linha, conseguimos abordar a Tradução Intersemiótica por todos os víeis que o mapa nos apresenta. Entretanto, é preciso focar naqueles que poderiam dialogar com a pesquisa que realizo. São três: (1) Estudo Teórico 
Parcial (ETP) - Tipo de texto, (2) Estudo Descritivo (ED) - Orientado ao processo e (3) Estudo Descritivo (ED) - Orientado ao produto.

É importante lembrar que essa descoberta se deu em rede. Isto é, confundem-se os momentos em que estes foram nossos objetos de partida com aqueles em que os objetos foram redelineados com o advento dos Estudos da Tradução em nossos Estudos Teóricos. A única forma que temos para esclarecer essas 'confusões' de cronologia está em observar como a rede se constituiu a partir da análise dos documentos de pesquisa, ou seja, se analisarmos as anotações, as gravações em áudio e vídeos, podemos detectar o percurso pelo qual as relações entre meu projeto de pesquisa e os Estudos da Tradução foram se estabelecendo.

Acredito que este detalhamento não caiba no momento, pois seria demasiado minucioso em um subcapítulo que não pretendo extenso. $O$ importante é reconhecer essas três abordagens que explicitei - tradução intersemiótica como (1) Estudo Teórico Parcial (ETP) do Tipo de texto, (2) Estudo Descritivo (ED), orientado ao processo e (3) Estudo Descritivo (ED), orientado ao produto - pois eles serão constantemente retomados quando estudarmos as outras redes.

Ademais, é o reconhecimento destas relações que foi nosso maior ganho com o estudo teórico dos Estudos da Tradução.

\section{b) A obra de arte viva - Adolphe Appia}

Esta obra surgiu por indicação de meu orientador, Prof ${ }^{\circ}$. Armando Sérgio da Silva, nos primeiros momentos da pesquisa, devido à necessidade de estudar as classificações das artes em tempo, espaço e performance. Assim, eu poderia melhor fundamentar minha escolha pelas linguagens que estão no recorte que estabeleci.

As relações com meu objeto de pesquisa também não foi linear, já que ora os escritos de Appia fundamentavam minha escolha, ora elas modificavam e contribuíam para minha forma de entender as relações entre Artes Plásticas, Cinema e Teatro. 
A primeira questão que esse livro nos apresenta tem a ver com a relação de todas as artes com o Teatro, e isso foi fundamental para eu entender a relação que explicitei no parágrafo anterior. Vejamos o ponto de vista histórico.

Na segunda metade do século XIX na Alemanha ocorreram tentativas de reformas cênicas do teatro. Entre as mais importantes, está a proposta de Richard Wagner (1813-1883) de um drama fundamentado na cooperação entre as artes, que traz consigo o gérmen de ideias que frutificarão mais tarde na obra de Adolphe Appia.

Para compreendermos o ideal de Wagner, é importante nos referirmos aos seus textos escritos entre 1850 e 1851 onde ele expressa suas ideias sobre a "obra de arte do futuro" em Das Kunstwerk der Zukunft (1850). Esta concepção está inteiramente incluída na noção de Gesamtkunstwerk, palavra que tem sido traduzida mais comumente como "obra de arte total" ou "obra de arte coletiva".

Wagner escreve:

A mais alta obra de arte coletiva é o drama, ele está presente em sua plenitude somente quando cada variedade artística, em sua plenitude, está presente nele. $\mathrm{O}$ verdadeiro drama pode ser concebido somente com resultado de um impulso coletivo de todas as formas de arte para se comunicar da maneira mais imediata com o público, cada forma artística individual pode se revelar como completamente inteligível a este público somente através de uma comunicação coletiva, juntamente com outras formas de arte. No drama, o objetivo de cada variedade artística individual é completamente alcançado somente pelo entendimento mútuo e a cooperação inteligível de todas as variedades artísticas. (WAGNER, 1950 apud DUDEQUE, 2009, p. 3)

Conclui-se que o drama, como pensado por Wagner seria uma arte homogênea, onde todas as linguagens artísticas confluem para uma unidade comum, ou seja, a reunião harmoniosa das artes. Já para Adolphe Appia a unidade desejada reside na representação teatral, uma harmonia completa entre os diversos elementos que compõem o espetáculo. Ele faz uma reflexão sobre as contradições do drama wagneriano e ataca a noção da Gesamtkunstwerk.

Para ele, a síntese entre as artes não passa de uma utopia, Appia escreve: “Se a arte dramática deve ser uma reunião harmoniosa, a síntese suprema de 
todas as artes, eu não compreendo mais nada de algumas destas artes, e muito menos a arte dramática, o caos é completo" (APPIA, 1921, p. 31).

Com a consciência da oposição ao drama wagneriano, Appia criticou as práticas teatrais de seu tempo. Condenou o espaço cênico italiano com sua oposição de dois mundos claramente distintos, o do espectador e o do mundo fictício, e propôs a criação de um mundo cênico em um mundo simbólico. Ele transforma a cenografia em um conjunto de signos que fornecem ao espectador possibilidades de leitura histórica, geográfica, social etc. Sua obra é, antes de tudo, de reflexão e está contida basicamente em seus três livros mais importantes: La Mise en scène du drame wagnérien (1895), Die Musik und die Inszenierung (1899) e L'oeuvre d'art vivant (1921).

Em A Obra de Arte Viva Appia faz uma distinção entre as artes temporais e as espaciais. Ele não tenta realizar o entendimento mútuo entre todas as artes proposta por Wagner, mas sim, busca uma síntese conciliatória para que a arte dramática atinja seu maior potencial expressivo. Em suma, nega a concepção wagneriana de uma ação comum entre as artes - afastando-se da concepção original de Gesamtkunstwerk - e propõem elementos para que o drama seja não total, mas vivo.

\begin{abstract}
Eis, pois, os artistas cuja atividade reunida deveria constituir o apogeu da arte dramática: um texto poético definitivamente fixado; uma pintura, uma escultura, uma arquitetura, uma música definitivamente fixadas. Coloquemos em cena tudo isto: teremos a poesia e a música que se desenvolverão no tempo; a pintura, a escultura e a arquitetura que se imobilizam no espaço, e não se vê de que maneira conciliar a vida própria de cada uma delas numa harmoniosa unidade! Ou haverá um meio de o fazer? O tempo e o espaço possuirão um elemento conciliatório, um elemento que lhes seja comum? A forma no espaço pode tomar a sua parte das durações sucessivas do tempo? E essas durações teriam ocasião de se propagar no espaço? Ora é a isto mesmo que o problema se reduz se queremos reunir as artes do tempo e as artes do espaço num mesmo objecto. (APPIA, 1921, p. 14)
\end{abstract}

Em suas reflexões, Appia chega a esse elemento. Ele indica o movimento como princípio diretor e conciliatório para fazer convergir todas as formas de arte para a arte dramática. "É no movimento que se opera a síntese anunciada". 
Contudo, ele alerta que o movimento em si não é um elemento, pois a mobilidade é "um estado, uma maneira de ser" (APPIA, 1921, p. 15).

A oposição a Wagner torna-se mais acentuada não apenas pela indicação do movimento como síntese, mas por Appia acreditar que essa convergência das linguagens não é totalmente estática, no sentido de que a união delas não se dá na sua forma integral. Há uma relação intrínseca que conduz os ajustes e adaptações pelos quais as linguagens devem passar, e isso é essencial ao processo de tradução intersemiótica - a transmutação.

Com o estudo de Appia, coloquei-me a examinar as linguagens das Artes Plásticas e o Cinema a fim de identificar quais elementos estão em relação com a mobilidade, como sistema em si ou quando em convergência para as Artes Dramáticas.

\section{c) Oficina da Essência - Armando Sérgio da Silva}

Este trabalho foi essencial para eu me orientar com relação ao meu processo de ensino e aprendizagem, sobretudo nas Oficinas Pedagógicas.

Nesse sentido, utilizei os conceitos de Ações, Procedimentos e Exercícios:

Entendo que nas 'metodologias' as Ações são constantes com ênfases diferentes, os Procedimentos são semelhantes, mas diferenciados pelo estilo do diretorprofessor, e os Exercícios são frutos da imaginação de cada um e, dependendo do tempo que se tem para aplicá-los, serão mais profundos. (SILVA, p. 00)

Outra relação que também foi retroativamente alimentada tem relação à elaboração da Dramaturgia do Ator. O autor, ao descrever a criação dramática dos alunos com relação aos estímulos, nos apresenta uma dificuldade.

Se o estímulo fosse, por exemplo, um gesto captado por uma foto, uma obra pictórica ou uma sequência musical, teria o aluno ator de realizar $o$ desdobramento no tempo e/ou no espaço do referido estímulo, visando a concatenação dramática que nem sempre é artifício de domínio dos atores. Essas opções poderiam causar dúvida no interprete a respeito dos resultados, ou seja, se conseguiu criar a concatenação de ações com qualidades dramáticas, condição essencial para a realização do processo de Interpretação Teatral. (SILVA, p. 50) 
A dificuldade de concatenação dramática que a maioria dos atores apresenta foi, de certa forma, nosso mote. Propus exatamente que os atores experimentassem essa consciência e exercício de conceber tanto ação como ficção, a partir de seus experimentos com os estímulos. Aliás, deixamos de chamar de estímulos para chamar de texto, pois assim os atores poderiam fazer uma pesquisa vertical nesses materiais, o que os ajudaria a ter maior número de elementos estéticos bem como uma compreensão de como eles se organizam, ou seja, como se concatena a malha do texto. Com esse conhecimento, acreditamos que o ator também seria capaz de organizar seu próprio texto.

\footnotetext{
O 'texto' do texto é o seu componente de concatenação, e o 'palco' do texto é o seu componente de simultaneidade, os aspectos diversos e frequentemente contrastantes, mas copresentes, que emergem na personagem e literalmente o enriquece. [...] A palavra 'texto', antes de se referir a um texto escrito ou falado, impresso ou manuscrito, significa 'tecendo junto'. Nesse sentido, não há representação que não tenha 'texto'. Aquilo que diz respeito ao texto (a tecedura) da representação pode ser definido como 'dramaturgia', isto é, dramaergon, o 'trabalho das ações' na representação. A maneira pela qual as ações trabalham é a trama. (BARBA apud DA SILVA, 2010, p.51)
}

Assim, a tarefa do ator seria "conhecer; desvendar o objeto, já que o que lhe foi dado não passa de um indício, de uma aresta, de um estímulo" (idem). Depois, o ator deve incorporar esse objeto e "como se ainda não bastasse, deve transformar esse objeto em um dado intencional de comunicação, em um signo articulado para a percepção do espectador." (SILVA, p. 53)

\section{d) Disciplinas Cursadas no PPG em Artes Cênicas}

Aqui, relato meu aprendizado ao cursar as disciplinas no programa de pós-graduação, ao passo que isso interage diretamente com o motivo pelo qual busquei a disciplina e como isso reflete na minha pesquisa diretamente.

- CAC5258 - Teatralidades Textuais Não-Dramáticas - Lugares de Luta na Linguagem da Dramaturgia Contemporânea: No decorrer da disciplina foi possível discutir as formas com que é manifestada a materialidade e a performatividade da cena teatral contemporânea no texto teatral escrito, 
levando em consideração o estudo dos elementos fundamentais da dramaturgia textual, como por exemplo, a mimesis, a ação, a personagem e a fala. Neste percurso, foi também oferecido uma contextualização sociocultural das teatralidades textuais nãodramáticas como problematização das práticas espetaculares na sociedade contemporânea referentes ao impacto da teatralidade e da poeticidade não-dramáticas sobre o mesmo contexto.

A disciplina também serviu para investigar e responder a questão sobre como a realidade contemporânea modifica a escrita teatral, através da leitura de autores como Fischer Lichte, Hans Thies Lehmann, Gerda Poschmann, Jeff Kons, Martín Crimp, Hugo Possolo, entre outros, para analisarmos tanto autores teóricos da poética teatral contemporânea, como dramaturgos que resistem à escrita dramática, e se utilizam do não-drama, criando, como diz Gertrude Stein, peças paisagens.

A dramaturgia pós-dramática em seu conceito e possibilidade de formatação foi um dos fatores de maior potência na relação entre a disciplina e meu projeto de pesquisa. Quanto à dramaturgia pós-dramática diz-se daquela também intitulada performativa e da qual aproximo da dramaturgia do ator.

No teatro do ator, a dramaturgia é uma ligação entre o texto original dramático e a instalação em cena, embora gostaria de enfatizar que a aproximação estabelecida entre o conteúdo ministrado na disciplina e os procedimento de encenação proposto estão em outros aspectos da dramaturgia para além das questões do texto escrito. É nesse sentido que a performatividade se manifesta; uma qualidade de expressão que chama atenção para a própria composição cênica.

Metodologicamente, proponho uma dramaturgia, que está baseada na dramaturgia do ator, do texto escrito pelo ator em cena, através das ações físicas e da ficcionalidade. Dessa maneira, como o texto do ator tem em si uma performatividade de fazer chamar atenção para o uso de outras linguagens, é esperado que no texto escrito da dramaturgia de cena essa performatividade também apareça na escrita, cumprindo assim a função performativa desenvolvida na disciplina, porém de um caminho da cena para o texto. 
- CAC5019 - Encenações em Jogo: Experimentos de Criação e Aprendizagem do Teatro Contemporâneo: Na disciplina, buscou-se realizar estudos teóricopráticos sobre uma proposta metodológica de ensino da encenação que visa a ampliação do repertório estético e metodológico na formação de artistas, pesquisadores e professores, no sentido de instrumentalizar a leitura, a criação e a aprendizagem da cena contemporânea.

Em aula, foram realizados experimentos de criação a partir da analise de registros de encenações teatrais, como uma forma de complementar a leitura, o debate e a produção de textos teóricos, como foco na aprendizagem e na criação da encenação contemporânea performativa de Josette Féral e pós-dramática de Hans T. Lehmann. As análise e a vivência de procedimentos de escritura cênica utilizados em encenações significativas foram, assim, o ponto de partida para o debate e a produção teórica, que tiveram como meta o entrecruzamento da reflexão dos artistas, teóricos e pedagogos do Teatro e da Performance, como linguagem artística.

Dentre o conteúdo ministrado, o que mais despertou meu interesse em relação à pesquisa foram os procedimentos de criação utilizados pelo encenador americano Bob Wilson, relativos à dramaturgia da imagem, com uso de simultaneidade, emolduramento, estranhamento, desconstrução, disjunção, repetição, justaposição e uso dos roteiros cênicos, ou storyboard.

Pela própria formação de Bob Wilson e pelo processo de criação da forma como ele o experimenta, é possível identificar muitos aspectos comuns à inter-relação de linguagens, do Teatro com Artes Plásticas e Cinema e, sobretudo o efeito que eles causam no tempo e espaço da cena. $\mathrm{O}$ uso do roteiro cênico foi também, sem dúvida, largamente utilizado nas experimentações práticas na pesquisa com os atores.

- CAC5261 - As poéticas de Antonin Artaud: contaminações entre a Escrita, o Cinema, o Teatro e o Desenho: $\mathrm{O}$ curso teve por objetivo percorrer o pensamento e a obra de Antonin Artaud (1896-1948), possibilitando fazer um 
estudo entrecruzado das poéticas da escrita, do cinema, do teatro e do desenho, bem como uma revisão, a partir de reflexões críticas contemporâneas.

Tratou-se também de ampliar a recepção sobre Artaud de não somente como um teórico do teatro, mas também como um teórico do corpo e da linguagem. Problematizou-se, nas aulas, sobre questões e conceitos de "impoder", no pensamento de Blanchot; de "subjétil", "pensamento do lance", "pictografia" e "múmia" em Derrida; de "palavra-sopro" e "corpo sem órgãos" em Deleuze, para aprofundar a visão sobre como Artaud (2004) seria uma referência para o pensamento crítico e artístico contemporâneo.

Meu artigo final para a disciplina fundamentou-se no texto Encenação $e$ Metafísica, encontrado na obra O Teatro e seu Duplo, do autor francês, pois foi nesse aspecto que residiu maior interesse relativo à pesquisa. Para discutir melhor as questões relativas à encenação, Artaud inicia com uma pergunta:

\footnotetext{
Como é que no teatro, pelo menos no teatro tal como o conhecemos na Europa, ou melhor, no Ocidente, tudo o que é especificamente teatral, isto é, tudo o que não obedece à expressão através do discurso, das palavras ou, se preferirmos, tudo que não está contido no diálogo (o próprio diálogo considerado em função de suas possibilidades de sonorização na cena, e de exigências dessa sonorização) seja deixado em segundo plano? (ARTAUD, 2004, p.36)
}

A partir desta questão inicia-se o primeiro ponto de convergência entre o conteúdo da disciplina e a pesquisa em questão, referente à Dramaturgia do primeiro exercício cênico que fizemos, Efêmea. Numa dramaturgia que assume a igualdade de importância das diversas camadas de significados, não há espaço para um textocentrismo ou para um teatro dialogado. É nesse sentido que a performatividade se manifesta; uma qualidade de expressão que chama atenção para a própria composição cênica.

Artaud propõe que se discuta um teatro que, antes de mais nada, problematize uma linguagem em crise em um contraponto sobretudo com um corpo em crise, especialmente por este estar aprisionado pela linguagem. Os escritos do autor vêm a enriquecer não só as leituras, mas, sobretudo as preocupações em escolher as linguagens de Artes Plásticas e Cinema a fim de 
fundamentar uma encenação que possa despertar vários níveis de sentido dos indivíduos em cena - ator e espectador - constituindo uma poesia:

Essa poesia muito difícil e complexa reveste-se de múltiplos aspectos: em primeiro lugar, os de todos os meios de expressão utilizáveis em cena, como música, dança, artes plásticas, pantomima, mímica, gesticulação, entonação, arquitetura, iluminação e cenário. (ARTAUD, 2004, p. 37-38).

Essa poesia é possível no jogo com os diversos sistemas de signos:

\begin{abstract}
Uma das formas dessa poesia no espaço - além daquela que pode ser criada com combinações de linhas, formas, cores, objetos em estado bruto, como acontece em todas as artes - pertence à linguagem através dos signos. [...] este outro aspecto da linguagem teatral pura, que escapa à palavra, da linguagem por signos, gestos e atitudes. (ARTAUD, 2004, p. 38)
\end{abstract}

Como hieróglifos, esses signos são marcados pelo o que há de humano e singular nesta linguagem pura, na construção de significados, tendo se dirigido inicialmente aos sentidos. Há ainda o fato de, ao trazer diversos sistemas de signos para o procedimento de encenação, seja, para Artaud, possível perecer que cada um dele possui uma poesia própria, intrínseca e que depois revela-se numa espécie de "poesia irônica que provém do modo como ele se combina com os outros meios de expressão" sendo então "fácil perceber as consequências dessas combinações, de suas reações e de suas destruições recíprocas" (ARTAUD, 2004, p.38).

- CAC5436 - O Texto corporal do Ator em Cena: No decorrer da disciplina foi possível discutir e experimentar os princípios básicos da mímica, bem como, técnicas de síntese, precisão, ilusão e a construção de um texto físico através das ações. Neste percurso, foi também possível exercitar o uso dos princípios estudados para criação de dramaturgia não verbal, através das inúmeras demonstrações cênicas em classe.

Em relação à pesquisa, usamos alguns dos princípios corporais usados para atores, em sua formação e em cena, e que foram estudados durante a 
disciplina. Tais como: peso, importância, tempo/velocidade, necessidade, equilíbrio, sustentação, jogo e interatividade.

Com o projeto de pesquisa, foi possível estabelecer uma relação entre os princípios dos estudos corporais com o espaço e o tempo cinematográfico, pois em paralelo às aulas eu estava experimentando procedimentos de criação voltados para esta linguagem. Ainda por conta da disciplina, cada aluno apresentou um seminário teórico e prático sobre sua pesquisa.

Iniciei o seminário com uma explanação teórica sobre os principais conceitos da minha pesquisa: a Dramaturgia do Ator e a Tradução Intersemiótica. Após a explanação teórica, sugeri um exercício prático já tendo em mente o principal questionamento a fazer: quais dos princípios estudados em classe dialogavam diretamente com a necessidade técnica que estávamos prestes a vivenciar?

O exercício deu-se da seguinte forma: Exibi um trecho do filme Blow Up (Antonioni, 1968) como exemplo de texto cinematográfico. Este filme - já uma tradução intersemiótica em si, pois foi baseado em parte no conto do escritor Julio Cortázar, Las Babas del Diablo - gira em torno de um fotógrafo de moda londrino, que numa manhã fotografa um casal ao passar por um parque da cidade e a partir das revelações e ampliações das fotos, ele acredita ter testemunhado um crime.

Na sequência do exercício, comentamos sobre o que tornava aquele trecho um exemplo claro da linguagem do cinema: os enquadramentos, os cortes, os planos, a montagem. E então, em duplas, os outros atorespesquisadores propuseram-se a realizar a tradução intersemiótica do trecho assistido em uma cena teatral. Eles elaboraram a sim, sua própria dramaturgia, ou seja, a dramaturgia do ator.

As reflexões foram bastante pertinentes, pois demonstraram que antes da tradução em si, há a escolha dos signos a serem traduzidos e que entre os signos há uma distinção de importância, ou seja, há muitas possibilidades de tradução para o mesmo texto. Embora pareça um processo limitador, ele mostra que quanto mais rico em signos e significação forem o repertório do ator e os textos 
escolhidos, mais aberto e potente o é enquanto processo criativo. Assim, compreendi que é preciso trabalhar na instrumentalização de leitura dos atores.

- CAC5021 - Teatro e Novas Tecnologias: No decorrer da disciplina foi possível discutir e também investigar quais as diferenças trazidas pelas tecnologias nos aspectos de alteração do efeito estético e no posicionamento artístico, histórico e político dos grupos e encenadores estudados - e como as novas tecnologias implicam diretamente nos rumos da cena teatral e colaboram para construção da teatralidade.

Entre as questões problematizadas em sala em relação ao conteúdo, notei a presença pontual de convergências e divergências com o meu projeto de pesquisa em mestrado. As principais relações são feitas em função dos conceitos que resultam da implicação do uso das tecnologias na cena teatral.

Entre os que foram problematizados cito o Hibridismo, a Variabilidade, o Imediatismo e a Simultaneidade que podem ser alcançados mediante procedimentos de criação, como a Cineficação, o Fantasmagórico e a Webzação. Acredito que as unidades II - Utilização da Tradição e Inovação da Tradição e III - Inovação e História tem maior ponto de contato com minha pesquisa.

Para ilustrar a Utilização e a Inovação da Tradição a professora Piccon Valin comentou detalhadamente sobre o impacto criado pelo cinema sobre a cena teatral, enquanto linguagem e experiência estética. Esse impacto foi significativo a tal ponto de toda uma geração de artistas terem se debruçado sobre o processo de cineficação do teatro, que pretendia acompanhar as demandas atuais de espectador e assim produzir de forma a levar tantas pessoas ao teatro quanto ao cinema. Os encenadores que melhor representam o processo de cineficação são Meyerhold, Langoff e Piscator.

Os espetáculos La bal masqué, Le Cocu Magnifique, La forét e Le Revizor de Meyerhold são fundamentais para exemplificar a alterações que a cineficação causou sobre o tempo e o espaço cênico, de forma que ilustram o primeiro ponto de convergência com o projeto: a relação entre o Ator, o Tempo e o Espaço no Cinema e no Teatro. 
Em La bal masqué tem-se em jogo o pensamento sobre cinema. Em cena, há o uso de cortinas que criam planos, trabalham o espaço de maneira diferente e resignificam um elemento cênico, a cortina, por lhe dar outra função. Uso da cortina nesse espetáculo foi feito para "focalizar", "recortar", "enquadrar", "fechar". De cenário grandioso esteticamente, porém simples em materias, La bal masqué também colocou em cena spots para maior foco de luz sobre uma mesa. No espetáculo a agilidade na troca de planos foi um ganho também, podemos pensar na alteração do espaço com efeito no tempo cênico.

O processo de cineficação tentou na prática, através de procedimentos e dispositivos, projetos estéticos e propostas de encenação mais antigas como as que vimos no começo da Unidade III - Inovação e História, quando a professora Piccon Valin retomou o pensamento de Antonin Artaud sobre o teatro.

Localizo neste momento o segundo ponto de convergência com a pesquisa, quando Artaud (2004) coloca em questão as propostas de encenação feita ao espectador. Com o estudo sobre a cineficação podemos notar que o esforço foi em sentido de processo criativo, mas que também considerou a sensação e o efeito estético causado, tanto que muitos encenadores tiveram inclusive projeto para a arquitetura teatral em função de que a tecnologia integrasse totalmente os atores, espectadores e seus dispositivos privilegiando vários pontos dos quais se podiam ver as ações cênicas. Tal proposta vai de encontro com as proposições de Artaud para um teatro de imersão completa.

A cineficação, mas também o fantasmagórico e a webzição, assim como todos os procedimentos estudados em relação às tecnologias para a cena, retomam vários dos muitos princípios colocados por Artaud para a encenação e teatralidade. Eles traduzem na prática essas ideias se valendo de técnicas que só foram possíveis com o próprio avanço tecnológico em detrimento da época vivida por Artaud.

Os procedimentos discutidos foram interessantes para pontuar historicamente e expor algumas técnicas usadas, porém o assunto de "Teatro e Novas Tecnologias" pode avançar muito se pensarmos no teatro como próprio produtor, gerador das tecnologias, não como uma linguagem que se apropria 
de tecnologias, maquinários e da digitalização para acompanhar um processo histórico.

Assim, encerro a descrição das relações e conexões que compõem a primeira rede da pesquisa, os Estudos Teóricos. Percebo que a maior recorrência esteve na constante tentativa de conceituar a Tradução Intersemiótica e a Dramaturgia do Ator, como tenho proposto, já que são conceitos interdisciplinares, o que implica em pesquisa em áreas muito abrangentes.

\subsection{OFICINAS PEDAGÓGICAS}

Após ter cursado a disciplina O Texto corporal do Ator em Cena, ministrada pelo Prof ${ }^{\circ}$. Eduardo T. Coutinho, decidi pesquisar mais sobre ações, procedimentos e exercícios que poderiam me ajudar a instrumentalizar o ator para praticar a tradução intersemiótica. Assim, surgiu a segunda rede da pesquisa, as Oficinas Pedagógicas.

As Oficinas foram divididas em três: (1) Estudos da Linguagem, (2) Estudos do texto e (3) Estudos do signo, que inicialmente foram lineares, mas que depois nos exigiu que retomássemos os conteúdos, sempre que necessário. Participaram das oficinas: Christiane Martins (atriz e também mestranda no programa de pós-graduação em Artes Cênicas, na ECA), Bruna Lima e Áurea Teixeira Barros (alunas da Escola de Arte Dramática), Patusca (atriz profissional e dramaturga), Elton Santos e João Attuy (alunos da EAD e atores da Cia. Teatro da Vertigem) e Fabiano Benigno (encenador).

A seguir descrevo os procedimentos e alguns exercícios que utilizamos.

\subsubsection{LINGUAGEM}

Como ponto de partida, localizei os elementos de tempo, espaço e mobilidade, que foram estudados por Appia, para compreender a dinâmica dos 
sistemas de signos escolhidos: Artes Plásticas e Cinema. Devo lembrar que Appia não estudou o Cinema, mas pesquisei-o para pensar a fusão tempoespaço em sua relação ao tempo-espaço cênico.

Essa abordagem nos permite estudar as linguagens a partir de suas essencialidades, do que lhe é próprio e único, do que a caracteriza mais essencialmente. Já sob o ponto de vista da transmutação, vemos como as essencialidades dialogam e como os textos revelam-se e articulam-se nesse diálogo, dando origem a um novo texto, por meio de um signo traduzindo-se em outro.

O problema em elaborar uma teoria dos sistemas não verbais tem muitas origens. O filósofo Jacques Derrida sustenta que a afirmação tradicional - de que a linguagem representa uma realidade objetiva - é uma manobra problemática que cria em si a ilusão de que um reino objetivo não-linguístico é espelhado na língua, que exemplifica a dicotomia pela qual entendemos linguagem.

Desde o século XVII, quando as disposições dos sistemas de signos passaram a variar entre binários e ternários, os teóricos perguntaram-se como um signo pode realmente designar e estar relacionado com o que ele significa. A análise da significação foi o caminho encontrado por eles para responder, assim, a linguagem passa de representação para significação e as artes atingem sua essência quando são questionadas não no nível do que significam, mas em sua forma significante, são operações significantes da linguagem.

Cronologicamente, sabemos que o estudo dos signos ocorreu em paralelo com a contribuição de Saussure para a Semiologia e de Pierce para a Semiótica. O aspecto hermenêutico do signo, em oposição ao linguístico, foi desenvolvido na Semiótica pierciana, na qual o signo vai além da palavra e obtém um maior potencial de interpretação:

O signo é uma coisa que representa uma outra coisa: seu objeto. Ele só pode funcionar como signo se carregar esse poder de representar, substituir uma outra coisa diferente dele. Ora o signo não é o objeto. Ele apenas está no lugar do objeto. Portanto ele só pode representar esse objeto de um certo modo e 
numa certa capacidade [...] substituem-na, apenas, cada um deles de um certo modo que depende da natureza do próprio signo. (SANTAELLA, 2007, p. 58)

Nessa citação aparecem os principais aspectos do signo em Pierce que é a expansão do signo para além da palavra e sua substituição de um signo por outro signo - tradução - depende de sua própria natureza e qualidade do signo. Nos subitens que se seguem, apresento uma síntese do estudo dos sistemas de signos escolhidos, como forma de introduzir os elementos que entraram em jogo quando iniciei as atividades práticas de oficina, sendo a primeira em Estudo das Linguagens.

\section{- ACCÃO 1: CONTEXTUALIZAR AS LINGUAGENS NA PESQUISA}

\subsubsection{Artes Plásticas}

Para a transmutação em artes cênicas, o movimento é um princípio único e indispensável, é ele que ele ordenará hierarquicamente as formas de arte a partir das ações do ator, subordinando-as umas as outras, em busca da unidade harmonia. Entretanto, apenas o entendimento da mobilidade como síntese da convergência não encerra a dificuldade de compreender como se dá, em cena, essa reunião harmônica, pois que algumas dessas artes "deve a sua perfeição, o seu acabamento, à sua própria imobilidade" (APPIA, 1921. p. 16). O autor questiona: "como aplicar o movimento àquilo a que chamamos belas-artes, que são, pela sua própria natureza, imóveis?" (APPIA, 1921, p. 18).

Ao tratar das Artes do Espaço, Appia traça paralelos entre a aproximação do corpo com as Belas Artes: a arquitetura, a escultura e as artes plásticas. Para ele, o corpo além de móvel é plástico, e esta plasticidade coloca-o em relação direta com a arquitetura e aproxima-o da escultura, sem que, com esta, ele possa se identificar diretamente posto que ela seja imóvel. Por outro lado, Appia afirma que o modo de existência da pintura não pode nem lhe servir: 
se na sua própria atmosfera, nas suas próprias luz e sombra. É o mesmo que se passa com as formas indicadas pela pintura; essas formas não são plásticas, não possuem três dimensões; o corpo tem três; a sua aproximação não é possível. As formas e a luz pintadas não têm, pois, lugar na cena; o corpo humano recusa-as. (APPIA, 1921, p, 13)

Mais categoricamente ele completa que "ou a pintura renuncia à sua existência fictícia a favor do corpo vivo, o que equivale a suprimir-se a si própria; ou o corpo tem de renunciar à sua vida plástica e móvel, dando à pintura uma posição superior à sua", o que ele acredita ser a negação da arte dramática (APPIA, 1921, p. 14).

Dessa forma, Appia recusa a ideia de que as Artes Plásticas possam contribuir com a arte dramática (arte integral). Pela mobilidade e tridimensionalidade do corpo recusar a essencialidade da pintura. Acredito que talvez Appia recuse essa aproximação por pensar em uma relação entre as linguagens que vise uma correspondência exata, uma contribuição direta de elementos integrais nesse processo. E o que a Tradução propõe não são vetores que apontam para um mesmo alvo, mas talvez vetores que se entrecruzam.

A tradução tem o poder de adaptação e transformação dos vetores. É como se os vetores transformassem-se ao longo do caminho. Chegando ao local alvo, modificados pela necessidade de expressão do corpo vivo e plástico, orientados por uma transcriação, portanto, um novo texto, discurso. Dessa aproximação, onde os ajustes e as adaptações são a própria resolução criativa, nem as Artes Plásticas abandonam sua essencialidade, nem o corpo sua dramaticidade: dessa relação nasce outras significações altamente estéticas e que instigam e alimentam a criação do artista teatral. Não se trata, assim, de escolher as artes plásticas para o jogo da transmutação em busca de a pedagogia maior dessa inter-relação, uma correspondência exata e universal, mas de apontar princípios de experimentação (procedimentos e exercícios) que os artistas podem usar quando em criação, para acessar de forma consciente seu repertório e fazer uso do mesmo num processo metodológico de encenação que os ajudem a se apropriar do experimento.

Há uma diferença clara em abordar a pintura por seus elementos espaciais expressivos, pela sua linguagem e entende-la como um texto, um 
discurso que se revela na linguagem. Da forma como Appia a coloca ele pensa nessa conjunção de linguagens, vetores de união. Não estou propondo a decupagem da linguagem teatral, como uma arte integral via artes do espaço e do tempo, como formas fixas de entender o teatro. Mas sim como um intercurso, uma confluência.

Ainda sobre a citação de Appia quanto à renuncia fictícia da pintura, acredito que não se trata de suprimir-se, mas sim de priorizar o meio em que se vai executar a escritura. É possível ler uma pintura que contenha em si todos os elementos essenciais de uma cena, e que revele seu discurso. Estamos propondo o outro caminho. E se for uma questão de suprimir-se, temos que assumir essa supressão, pois é nela que encontramos sua essencialidade: a imobilidade.

\footnotetext{
A pintura não imobiliza apenas um estado fugitivo do mundo exterior; procura exprimir, por meios subtis que lhe são profundos, o estado precedente e o que se lhe segue, ou que poderia verossimilmente seguir-se lhe. A pintura contém, portanto, o movimento em potência. (APPIA, 1921, p. 15)
}

A pintura contém, portanto, uma imobilidade latente, que é nada mais que o movimento em potência a que o autor se refere. É a partir dessa imobilidade que a cena busca as sutilezas do antes e do depois, construindo a narrativa. Appia acredita que esse movimento se imprime pelas formas e cores, mas uma análise mais específica do sistema das artes plásticas, nos mostra que ele desdobra-se e revela-se igualmente no espaço e no tempo da pintura. E é, portanto, com essa orientação que continuamos o estudo da essencialidade das Artes Plásticas e sua relação com as Artes Cênicas.

\subsubsection{Cinema}

A partir da leitura de O cinema como arte (1969) de Stepherson e Debrix é possível localizar as qualidades expressivas do tempo e o espaço cinematográficos, ao passo que, para entendê-los como significantes, me apoio nos estudos de Cristian Metz e a Semiologia do Cinema. Para os demais aspectos, outras referências foram utilizadas. 
Embora escrito em 1969 e, por isso, retratar apenas metade da produção cinematográfica feita até hoje, O cinema como arte permanece atual. Foi sem dúvida uma importante contribuição ao detalhamento do cinema, preliminarmente, como linguagem, técnica e arte.

As questões sobre tempo e espaço já foram há muito redimensionadas e relativizadas na contemporaneidade, porém, este registro, permite uma localização objetiva dos eixos e um contato com a tradição. Por conveniência de análise, o livro discute espaço e tempo separadamente, e já no capítulo tempoespaço em cinema nos apresenta a conjunção em relação ao Movimento e à Montagem.

Em relação ao Teatro, o Cinema tem duas diferenças muito importantes:

A diferença mais importante é que a tela é externa para o espectador, que não está envolvido nela como em um ambiente normal. [...] Em segundo lugar, no cinema podemos só ver e ouvir - nossas sensações de visão e audição não são suplementadas pelo tato ou pelo peso, e em consequência não podemos calcular precisamente volumes, distâncias e densidades. (STEPHERSON, 1965, p. 36)

Sobre esta citação, podemos dizer que ela evidencia a sensação de distanciamento que o espectador de cinema experimenta em relação ao que se passa, enquanto que o espectador do teatro pode vir a ter uma interação maior com o ambiente, com o espaço cênico. Em seguida, o autor nos apresenta um exemplo sobre as diferentes dimensões espaciais:

Tomemos um exemplo: como o cinema dá uma visão bidimensional de um mundo tridimensional, objetos não são necessariamente reconhecíveis na tela, independentemente de como são fotografados. Devem ser tomados do ângulo certo e com certa iluminação [...]. No cinema o espectador não está só fora do quadro espacial das coisas que vê na tela; está também imóvel. A câmera tem que mover-se por ele, ou o objeto tem que mover-se na tela como uma superfície plana - um quadrado. (STEPHERSON, 1965, p. 36)

Esta característica afeta não somente o espectador, mas também o ator, no momento da tradução intersemiótica. A forma que com ele vai transpor a bidimensionalidade da tela cinematográfica para o espaço real em três dimensões passa pelo uso do princípio da interatividade, pois é preciso dar a 
mesma sensação de deslocamento espacial proporcionado pela câmera - como em travellings -, porém usando os recursos cênicos e, sobretudo o corpo do ator em cena.

Há outros princípios do trabalho corporal do ator, como peso, equilíbrio, suspensão e importância que entram em jogo na transmutação e dialogam diretamente com o a conjunção de espacialidade e temporalidades cinematográfica, através das unidades de filme, do enquadramento, dos ângulos e movimentos de câmera - assim como os demais elementos técnico-artísticos.

\section{a) PROCEDIMENTO 1: Pesquisar qual a(s) essência(s) das Artes Plásticas}

Segundo a autora Fayga Ostrower em Universos da Arte (1983), a abordagem mais objetiva com relação ao fenômeno artístico, no caso das Artes Plásticas, se dá a partir da compreensão dos conteúdos expressivos e a partir de critérios de linguagem artística, pois além de serem intra-artísticos, são determinantes para a qualidade das obras e captam o essencial da criação artística. Neste livro, a autora explica os princípios básicos atuantes na linguagem visual que são essencialmente noções de espaço.

Para comprovar que em Artes Plásticas "forma é igual a conteúdo" em termos de natureza espacial, a autora introduz, através de exercícios práticos, conceitos como Movimento Visual e Orientação e Direção Espacial.

Quanto ao movimento visual, ele diz respeito à marca visual que um traço, uma linha, deixa no espaço. Valendo-me de uma comparação que a própria autora faz entre uma linha a um gesto, ou uma palavra, pode-se pensar em procedimentos que exemplifiquem a singularidade da marca visual, deixada no espaço. Um dos exercícios aplicados pela autora dialoga diretamente com o principio da transmutação:

Fui ao quadro negro e dividi-o no meio. Em seguida, pedi para que um voluntário fosse ao quadro e num dos dois campos riscasse uma linha. Uma linha qualquer, de qualquer tamanho e em qualquer posição. [...] e eu precisa de mais um voluntário para fazer algo semelhante na outra metade do quadro. [...] Pedi que agora prestassem atenção, pois eu iria chamar um terceiro 
voluntário para tentar realçar esta última linha. Deveria percorrê-la cuidadosamente, exatamente, ir por cima do traçado sem mudar nada. Todos os presentes deveriam observar muito bem e de fato a linha original permaneceria igual, ou se de alguma maneira se alteraria. Um rapaz refez o traçado e a opinião foi unânime: a linha se alterou. (OSTROWER, 2003, p. 14)

Isso aconteceu, pois ao retraçar uma linha ela é sempre modificada. A modificação pode ser ligeira, mas não deixa de ocorrer. O mesmo acontece com o gesto, com a palavra e é o principio básico da tradução, a modificação, pois nessa relação da primeira com a segunda, aparecem ênfases que antes não existiam. Tal ênfase deve acentuar-se pelo deslocamento de sistemas, não mais interno às Artes Plásticas, mas em inter-relação com as Artes Cênicas.

Em uma investigação formal, do ator, orientada pelas marcas visuais plásticas, pode-se chegar à similitude entre forma e conteúdo: “Reconhecemos do mesmo modo no como das formas o quê, seu conteúdo expressivo. Em toda obra de arte, a forma incorpora o conteúdo de tal modo que se tornam uma só identidade".

Com relação às Orientações e Direções Espaciais, a autora a apresenta as noção de estabilidade e instabilidade, para onde as formas verticais e horizontais permitem a leitura do estável, enquanto as diagonais, curvas e espirais nos fazem ler o instável tanto no abstrato quanto no figurativo. Continuando nesse campo temos o Centro Geométrico e o Cetro de Percepção Visual, relacionando-se com a Densidade.

Há então, um viés de aproximação da concepção de espaço dado por Appia: “Temos, portanto, que contar com duas linhas principais: a horizontal, em primeiro lugar, porque o corpo repousa, antes de tudo, num plano, para exprimir a sua gravidade;" E completa: "depois, a vertical, que corresponde ao 'estar' do corpo e o acompanha." Retomando Appia, ele também escreveu sobre essa relação, porém sobre outra dimensão, não mais em função do corpo, mas analisando sobre o que o espaço se afeta dessa relação: "Para receber do corpo vivo a sua parte da vida, o espaço deve opor-se a esse corpo; adquirindo as nossas formas, aumenta ainda a sua própria inércia". Por outro lado, "é a oposição do corpo que anima as formas do espaço. O espaço vivo é a vitória das 
formas corporais sobre as formas inanimadas" (APPIA, 2005, p. 15). O corpo, com sua estrutura definitiva, não é possível de ser identificado no espaço senão por meio do movimento: os movimentos são a interpretação do corpo na duração.

Os termos citados nos parágrafos anteriores dizem respeito à expressividade do espaço em artes plásticas. Porém para compreender o sistema de signos dessa linguagem é preciso conhecer seus elementos expressivos. São eles: a Linha, a Superfície, o Volume, a Luz e a Cor.

Inicialmente sobre a linha, deve-se pensar o que faz a linha em estrutura espacial, qual sua função espacial. Segundo a autora Ostrower (1983), ela configura um espaço linear, uma dimensão. Através dela, apreendemos um espaço direcional, uma direção para o Movimento Visual. Em geral, uma a linha é rápida, pois nossa vista a percorre de ponta a ponta sem parar. Assim, seu movimento visual se dá no espaço e também no tempo. Nas configurações lineares, o tempo é visto desenrola-se dentro de um mínimo de espacialidade. Porém, há no traçado visualmente marcas, intervalos, como se fossem pausas. Essas falhas, recurso estético, reduzem a velocidade da linha, o que expressivamente modifica a leitura que teremos de um texto plástico através de suas linhas. Matematicamente, pensa-se que, em uma linha, quanto maior forem as pausas, menos é a velocidade impressa no movimento. $\mathrm{O}$ mesmo acontece com a direção espacial da linha: linhas em direções diferentes são contrastes entre si, e quanto maior o contraste, menor a velocidade e mais peso visual se imprime.

Essas qualificações de espaço e tempo constituem o clima expressivo da linha, contradizendo o pensamento de que as Artes Plásticas são somente uma Arte do Espaço. Muito embora o espaço seja o principal campo do fenômeno plástico, é possível pensar em qualidades estéticas de tempo através de uma pintura, por exemplo.

$\mathrm{O}$ segundo elemento, a superfície é aquela que torna evidente a bidimensionalidade da organização espacial pictórica em altura e largura. A superfície prende as linhas e as fazem dar contorno à área que recobrem. 
Matematicamente, quanto mais as duas dimensões se compensarem, proporcionalmente diminui-se o movimento visual. E dessa forma, reduzindose o movimento visual, reduz-se também o fluir do tempo. Há, no entanto, elementos dinâmicos acrescentados na pintura que deslocam certo texto plástico de um espaço idealizado a um espaço não ideal, devido à presença ou ausência de indicadores de tempo. Sendo a superfície um elemento mais de caráter mais estático, cabe a introdução de outros elementos no texto plástico para que se tenha dinamismo e elementos de mobilidade. Sua função é, portanto de localizar concentrações, blocos de significados estáticos em si, por isolação formal, o que cenicamente pode suscitar traduções em gestos ou ações mais segmentadas.

O terceiro elemento expressivo é o volume. Ele inicia uma importante distinção, pois enquanto que a linha e a superfície se inserem nas dimensões do plano pictórico, os elementos de volume, luz e cor sugerem ultrapassar a estrutura bidimensional e é por isso que são considerados mais dinâmicos. Com o volume, as linhas diagonais interligam-se com as verticais e horizontais e o espaço modifica-se de plano para profundo.

Outro aspecto essencial do volume é o jogo do invisível e visível que ele produz. Quer seja geométrico ou não, todo volume é um conjunto de planos que podem estar diante de nossa vista ou não, ou seja, podem estar 'escondidos' atrás de outro plano. A leitura não é prejudicada, ao contrário, ela acontece em função de. "Não só compreendemos o porquê de sua ausência, como também, pela coerência com que se interligam os diversos aspectos que formulam a profundidade nos volumes, somos capazes de inferir as áreas invisíveis pelas visíveis." (OSTROWER, 1983, p. 82) Por aglutinar os elementos de linha e superfície, o volume as pode modificar e elas passam a desempenhar novas funções, porém sem perderem a identidade espacial própria. A autora nos diz: "As linhas individuais assinalam agora limites comuns entre áreas vizinhas, unindo-as ao mesmo tempo em que as separam, e indicando em que lugar [...] ocorre uma mudança de direção nas várias faces que compõem a figura do volume." (OSTROWER, 1983, p. 82) 
Seguidamente, a luz é o quarto elemento expressivo no sistema de Artes Plásticas. A luz é o contraste formal entre o claro e o escuro, como elemento de linguagem visual, ela não pode ser vista como a reprodução do fenômeno natural da luz. Ainda que o artista possa se aproveitar do contrate claro/escuro presente no fenômeno em si, tanto natural quanto artificial, este contraste existe independente da existência de um foco de luz e é esse contrataste que conta na significação. Entretanto, para que o elemento se torne de fato expressivo, é preciso que todo movimento visual desdobre-se através da relação de valores claros e escuros, em grau e tamanho, avanço e recuo.

Embora estejam em relação, já que reunidos tronam-se expressivos, claro e escuro não deixam de ter sua individualidade e mais importante, sua significação original. A autora nos fala sobre o simbolismo da luz: "eles não são vistos, todavia, como polaridades de um mesmo modo de ser. [...] Ao contrário, o significado com que os relacionamos é o da contraposição, ou mesmo da oposição intrínseca" (OSTROWER, 1983, p. 225), essas qualidades de contrastes podem ser conflitos ou sintese.

Finalmente, temos as cores. O quinto elemento expressivo é um tema complexo posto que sua compreensão se dá pela relação e não apenas pela individualidade e logo, o valor exato de cada cor dependerá do conjunto em que é vista, ou seja, seu contexto colorístico. Isso desfaz a ideia de que isoladamente as cores já tem por si só um significado fixo. Ao contrário, todas as cores podem ter todos os significados dependendo do contexto expressivo no qual estão inseridas, suas funções e suas recepções. Dessa forma, para ler o significado de uma cor no texto plástico, basta ter conhecimento dos princípios das relações colorísticas, como elas funcionam e quais os possíveis efeitos das cores dentro de um contexto, pois com esse conhecimento pode-se saber em que sentido as cores tornar-se-ão expressivas.

O primeiro princípio diz respeito à sensualidade da cor: "por maior que seja nossa experiência prática, uma coisa é imaginar cores e outra, completamente diferente, é percebê-las. Na verdade, todas as cores são excitantes. [...] Há uma excitação dos sentidos, que é própria da cor" 
(OSTROWER, 1983, p. 236), e que a autora acredita não existir em nenhum outro elemento visual. O outro princípio é o da tonalidade, baseado na ideia das famílias de cores, que podem reconhecidas por seu valor cromático em relação de escala tonal (dos polos terminais claros aos escuros) e escala cromática (dos polos terminais intensos aos saturados). Segundo a autora, são os polos terminais que logo chamam nossa atenção, independente da sua posição, há outros tons que de acordo com sua intensidade cromática ficam por segundo e servem de passagem, e assim notamos um ritmo na cor, um aspecto de temporalidade: "nas áreas de contraste, o movimento visual se torna mais lento, podendo ser momentaneamente interrompido antes de continuar, ao passo que nos valores intermediários - áreas de transição - o movimento se torna mais veloz".

As cores relacionam-se também por primárias, secundárias e terciárias. E suas relações, embora complexas, basta que se olhe e observe quais cores existem em uma composição e o que fazem. Em uma pintura de tons azuis, por exemplo, constatamos a presença de tonalidades, consequentemente, há uma movimentação linear que caracteriza a forma do espaço. Ao contrário, se fosse introduzida outra cor, como por exemplo, traços de vermelho, o movimento se daria entre azuis contra vermelhos ou ao lado deles. Há ainda a relação entre cores quentes e frias - onde as quentes avançam, expandem-se e as cores frias recuam, retraindo-se - e há relação entre cores complementares, que são a relação entre uma cor primária e um secundária que induzem-se mutuamente. Dessas relações temos as tensões e fusões espaciais que dão movimento interno e externo ao que a cor designa, seja figurativo ou não.

Orientando-me pelos princípios das cores, e os demais elementos expressivos das Artes Plásticas, elaborei princípios e exercícios de leitura e apropriação para os atores reconhecerem nas combinações de formas, um discurso e seu potencial de mobilidade, sua correspondente ação.

\section{b) PROCEDIMENTO 2: Pesquisar qual a(s) essência(s) do Cinema}


Dentre as unidades espaciais de filme, temos, por exemplo, o quadro que é a menor unidade que um texto fílmico pode ter. Após o quadro, tem-se o take, que é uma tomada ininterrupta de filmagem. Seguidos da cena e da sequência, onde a cena é um conjunto de tomadas com uma narrativa já integrada e a sequência que, como seguimento maior do filme, é um conjunto de cenas.

Quanto aos enquadramentos, existe um grande estudo sobre sua significação narrativa com relação à distância estabelecida entre a câmera e o personagem, ou a câmera e qualquer objeto. Os enquadramentos são uma particularidade do cinema devido à variação do ângulo visual, diferentemente do Teatro, por exemplo, em que os ângulos de visão são, em geral, fixos ou estáticos.

Diferentemente acontece no Teatro quando ele altera sua proposta ao espectador, promovendo uma sensação semelhante a que ele experimenta no cinema, mediado pela câmera, pois é essa variabilidade de ângulos visuais que constitui a base da linguagem cinematográfica.

Os planos, ou shots, são classificados de acordo com dois elementos: a realidade fixada no quadro fílmico e a distância que separa a câmera do personagem ou objeto filmado. Os nomes dos planos são empregados tanto para a filmagem, já que definem as características técnicas da cena, e também para a compreensão da linguagem cinematográfica em si.

Inicialmente, temos o plano geral (long-shot) onde a câmera abrangente enquadra o máximo de paisagem e, em alguns casos, o mínimo de personagens. Sua aplicação está associada à elaboração de cores e tons, permite combinar melhor os pormenores de uma cena, está associada à abertura e se dar a conhecer o ambiente. (Figura 2)

O plano de conjunto assemelha-se ao plano geral, porém nesse, a atenção não está mais no ambiente e sim em um grupo de pessoas. A abertura do enquadramento é semelhante ao geral, entretanto a atenção do olhar e da narrativa alteram-se. Neste plano, os personagens existem tanto para si, quanto pelo grupo que formam. Sua aplicação pode ser de iniciar uma sequência envolvendo um grupo de personagens. (Figura 3) 


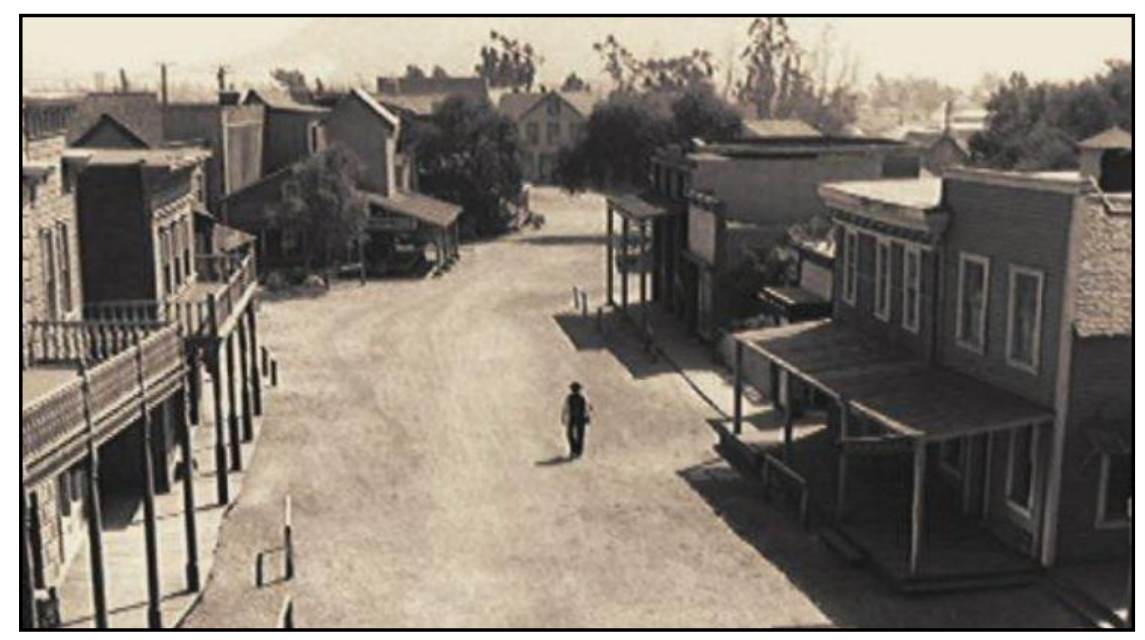

Figura 2: Exemplo de Plano Geral - NO TEMPO DAS DILIGÊNCIAS (Fonte: Arquivo Pessoal)

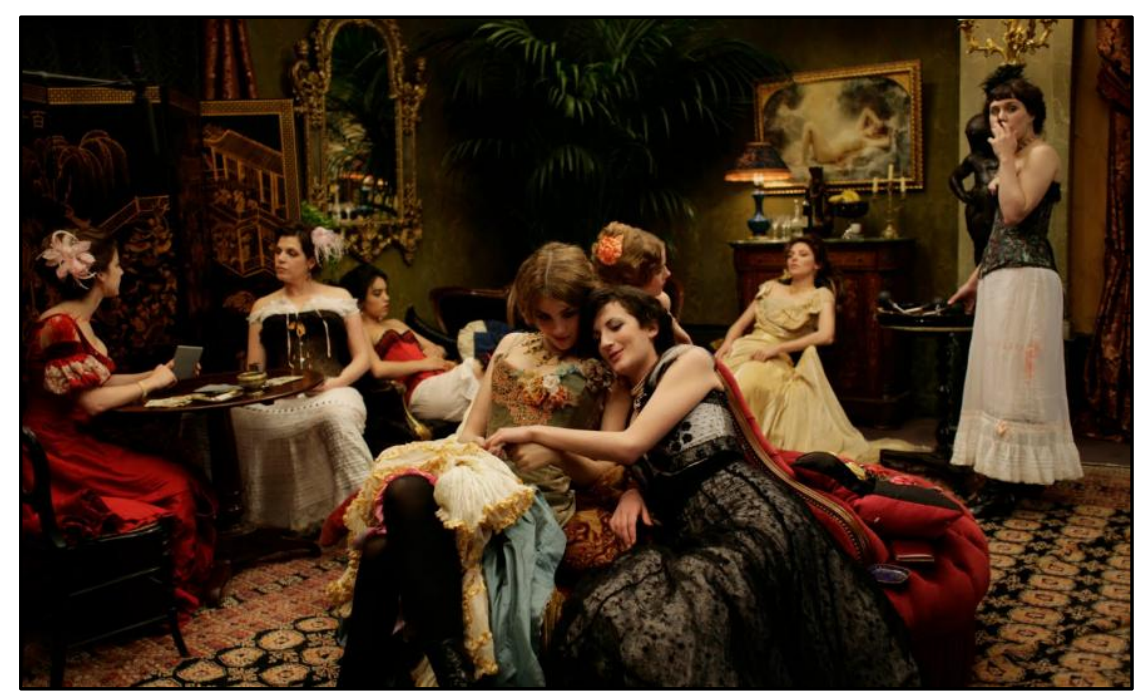

Figura 3: Exemplo de Plano de Conjunto - L'APOLLONIDE (Fonte: Arquivo Pessoal)

O plano aberto, pega todo o objeto da filmagem e o mostra em um espaço onde ele possa se movimentar. Nos é dado a conhecer esse objeto, ou personagem pela sua relação com o espaço, suas atitudes e gestos. (Figura 4)

O plano americano (two-shot) foi criado por D.W.Griffith, que chegou à conclusão de que a distância da câmera usada em sua época para enquadrar o personagem - estático e ator por inteiro, como se fosse um teatro - exigia da pessoa sendo filmada uma atuação muito dramática para que pudesse ser vista e entendida por todos. Inventou assim esse plano que se aproximava mais da pessoa, mostrando melhor e mais naturalmente sua expressão. Esse plano permite que vejamos os atores dos joelhos ou da cintura para cima. Usa-se o plano americano, em geral, para dar dinâmica ao diálogo entre personagens ou a caracterização de uma expressão. (Figura 5) 


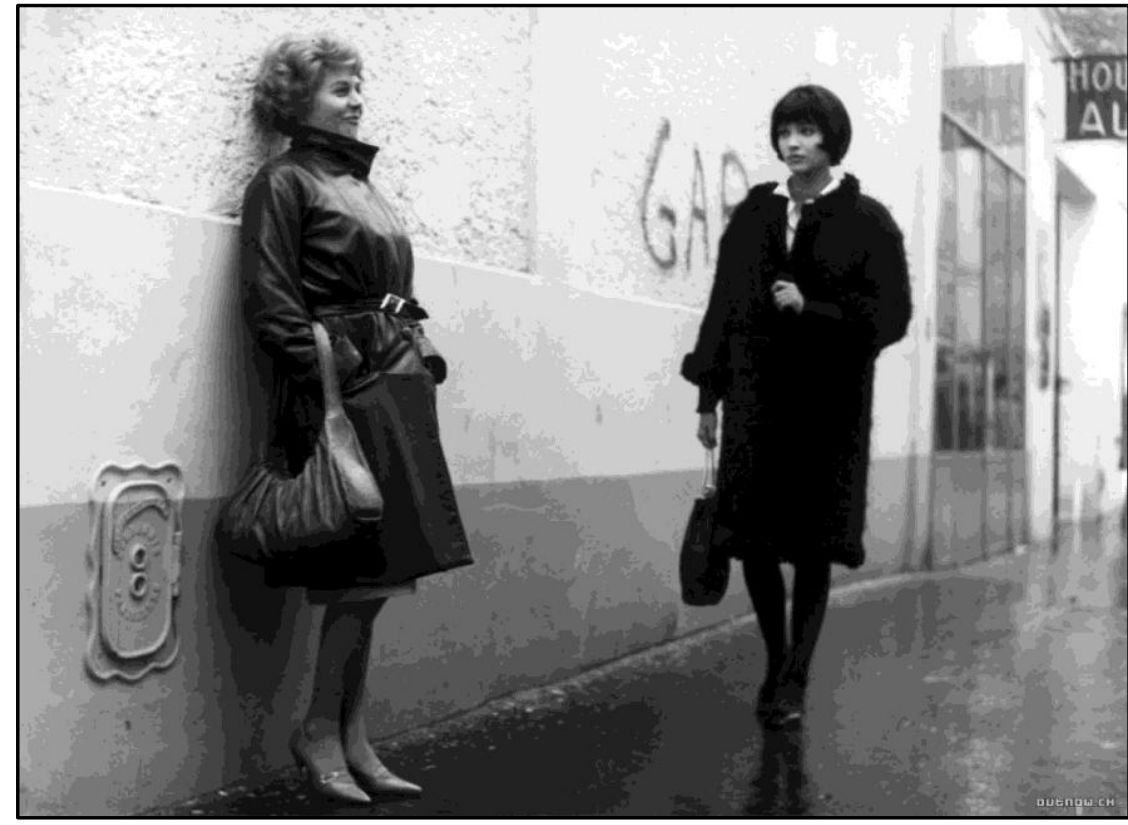

Figura 4: Exemplo de Plano Aberto - VIVER A VIDA (Fonte: Arquivo Pessoal)

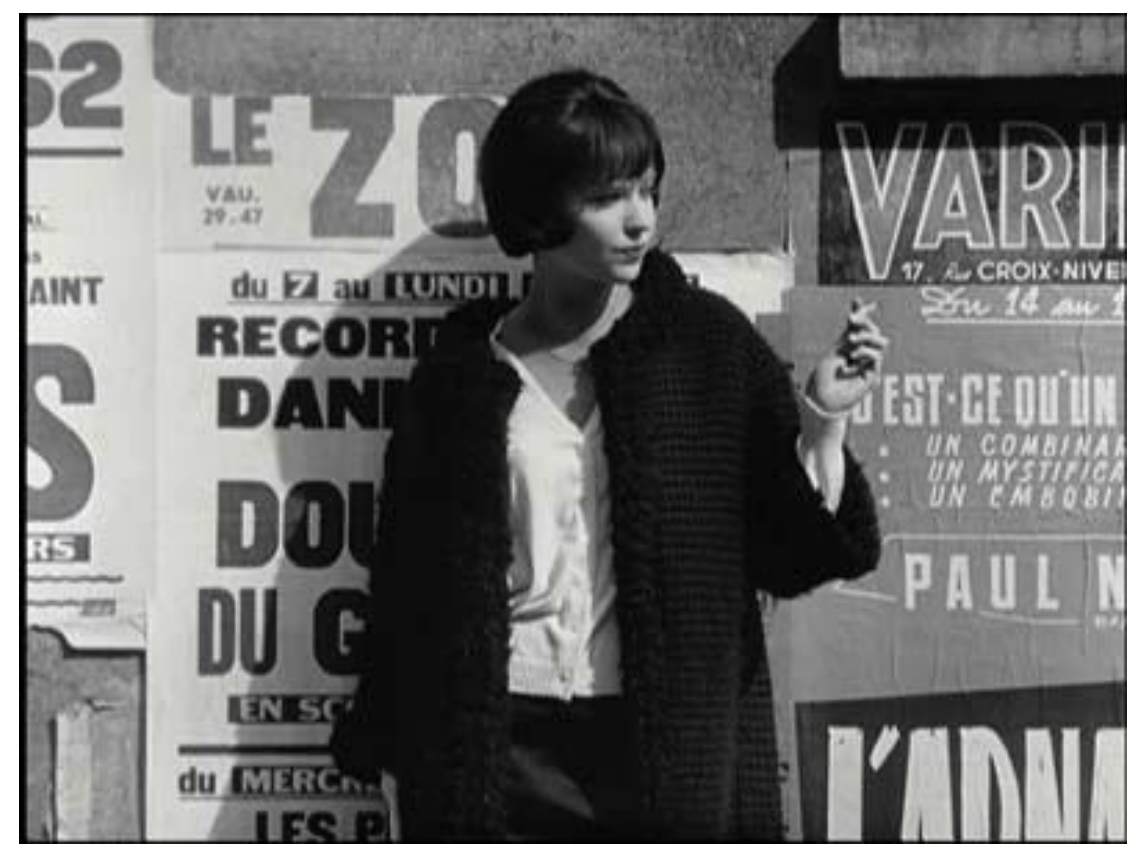

Figura 5: Exemplo de Plano Americano - VIVER A VIDA (Fonte: Arquivo Pessoal)

O plano médio mostra meio objeto. No caso de personagens, o corte é feito da cintura para cima. Com esse enquadramento conhecemos as reações da personagem, suas qualidades e fraquezas, como reações. (Figura 6)

Ainda em relação ao enquadramento, temos o primeiro plano (close) que se distancia de um personagem enquadrando-o em uma altura dos ombros para cima, assim, o personagem vira a informação primária que um espectador recebe e a informação secundária seria uma parte do ambiente em que ele se 
encontra. Se o foco estiver sobre um personagem, a atenção volta-se para algo que ele diz ou expressa, isto ocorre igualmente a um objeto. (Figura 7)

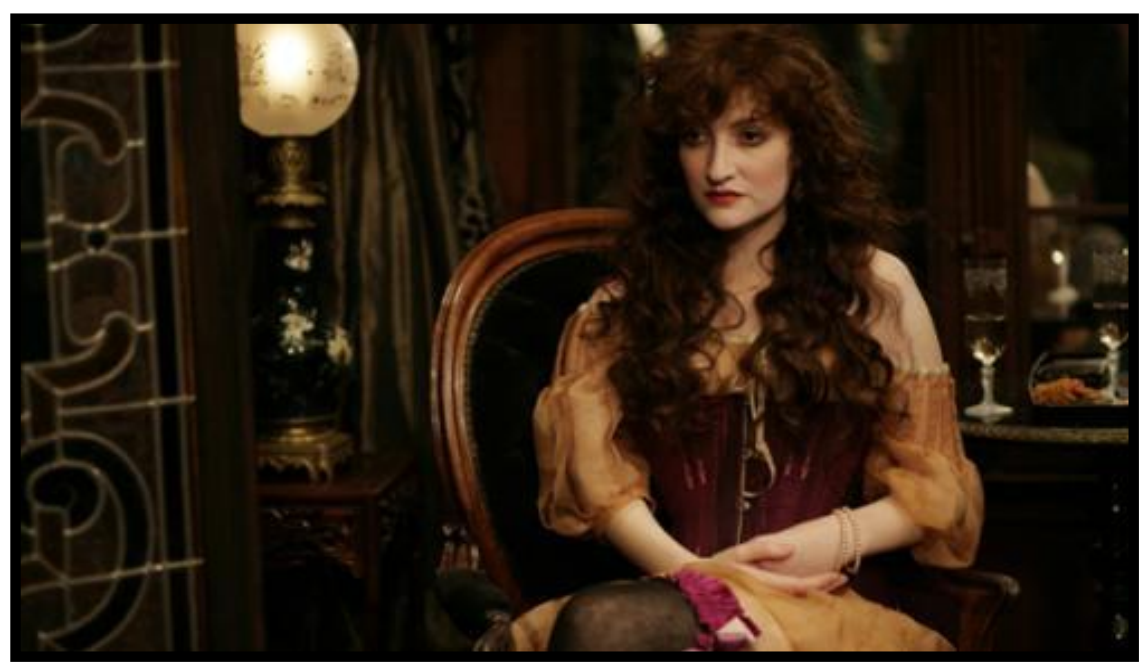

Figura 6: Exemplo de Plano Médio - L'APOLLONIDE (Fonte: Arquivo Pessoal)

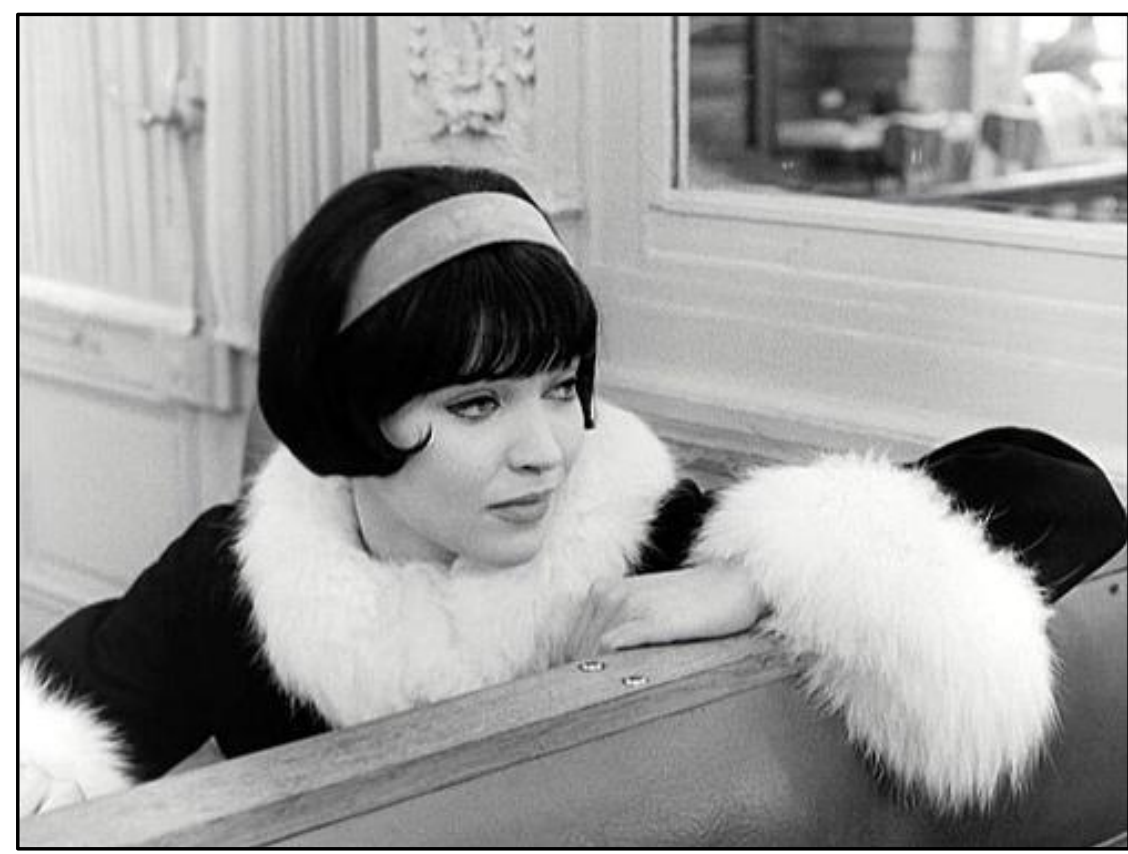

Figura 7: Exemplo de Primeiro Plano - VIVER A VIDA (Fonte: Arquivo Pessoal)

Há também o plano próximo (close-up), que se aproxima um pouco mais, vai-se além da superfície das aparências para tocar em revelações dramáticas, onde toda a informação é focada no personagem ou no objeto. Nesse plano a carga dramática está em função da importância, já que um rosto, por exemplo, pode ocupar a tela inteira revelando e definindo a condição emocional do personagem. Sua utilidade pode estar associada com outros aspectos além da carga dramática. (Figura 8) 
Aumentando essa importância temos o primeiríssimo plano e o plano de detalhe, a diferença está na diminuição da área de enquadramento. O primeiro mostra um recorte do rosto, do pescoço para cima, enquanto o outro mostra apenas uma parte do corpo do personagem ou algum aspecto mínimo do objeto. Matematicamente, quanto menor a área de enquadramento, ou seja, quanto maior o fechamento, proporcionalmente maior será a importância dramática. As imagens podem ser vistas nos anexos. (Figuras 9 e 10)

A linguagem cinematográfica também se constitui de ângulos de câmera, que podem ser: ângulo frontal, ângulo lateral, ângulo traseiro, ângulo $3 / 4 \mathrm{e}$ ângulo 1/4, câmera alta (plongée), câmera baixa (contra plongée), campo e contra-campo. Os ângulos variam nos eixos verticais e horizontais. Já os movimentos de câmera são do tipo: fixo, panorâmico, travelling e zoom.

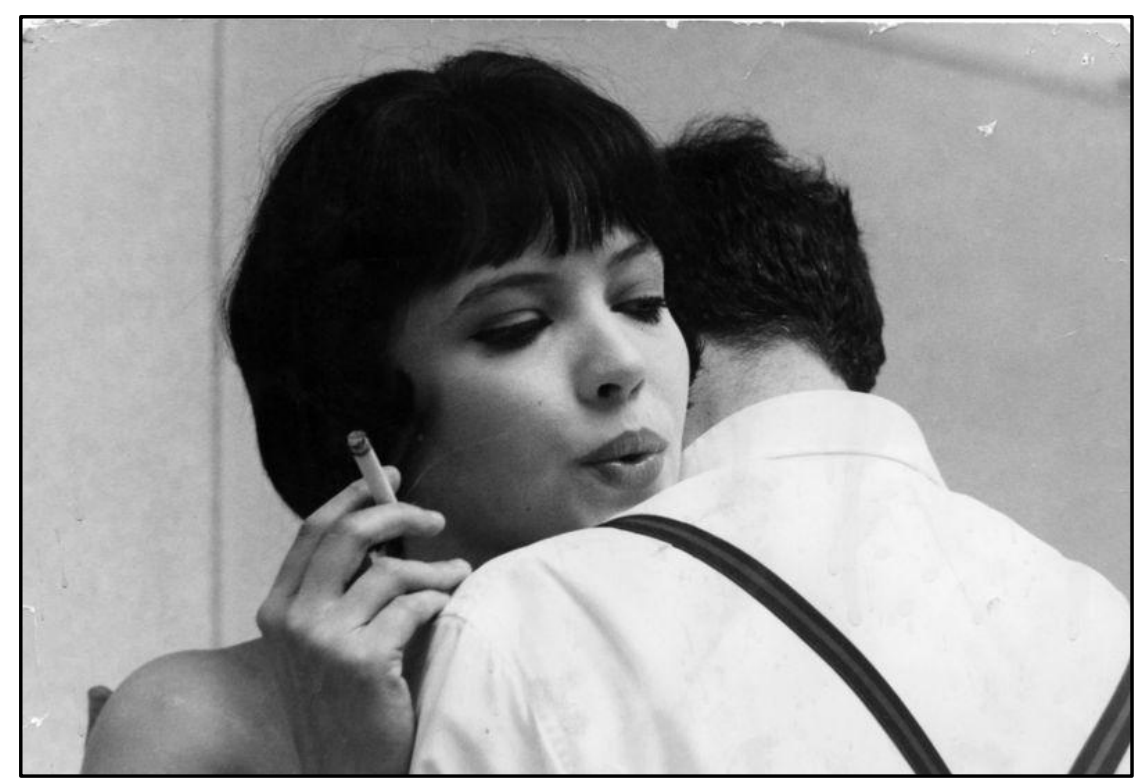

Figura 8: Exemplo de Plano Próximo - VIVER A VIDA (Fonte: Arquivo Pessoal)

Em relação ao Movimento, é interessante notar que ele está diretamente ligado à noção de espaço-tempo, em duas dimensões: 'o real' e o cinematográfico, na qual o primeiro seria contínuo e menos evidente que o segundo. É o movimento que articula a narrativa no cinema. Entretanto, se a narrativa for entendida como um encadeamento de um determinado número de ações que se desenvolvem entre um começo e um fim, e que essas ações pertencem ao universo narrativo ao estabelecerem uma lógica que visa a inteligibilidade através das relações geradas, ela não pode ser específica de um 
tipo de arte. Não existe uma narrativa teatral ou uma narrativa cinematográfica; existe, sim, uma narratividade, forma de atualizar a narrativa de uma expressão específica que ganha significações a partir dos elementos específicos de cada arte, no caso a linguagem do cinema.

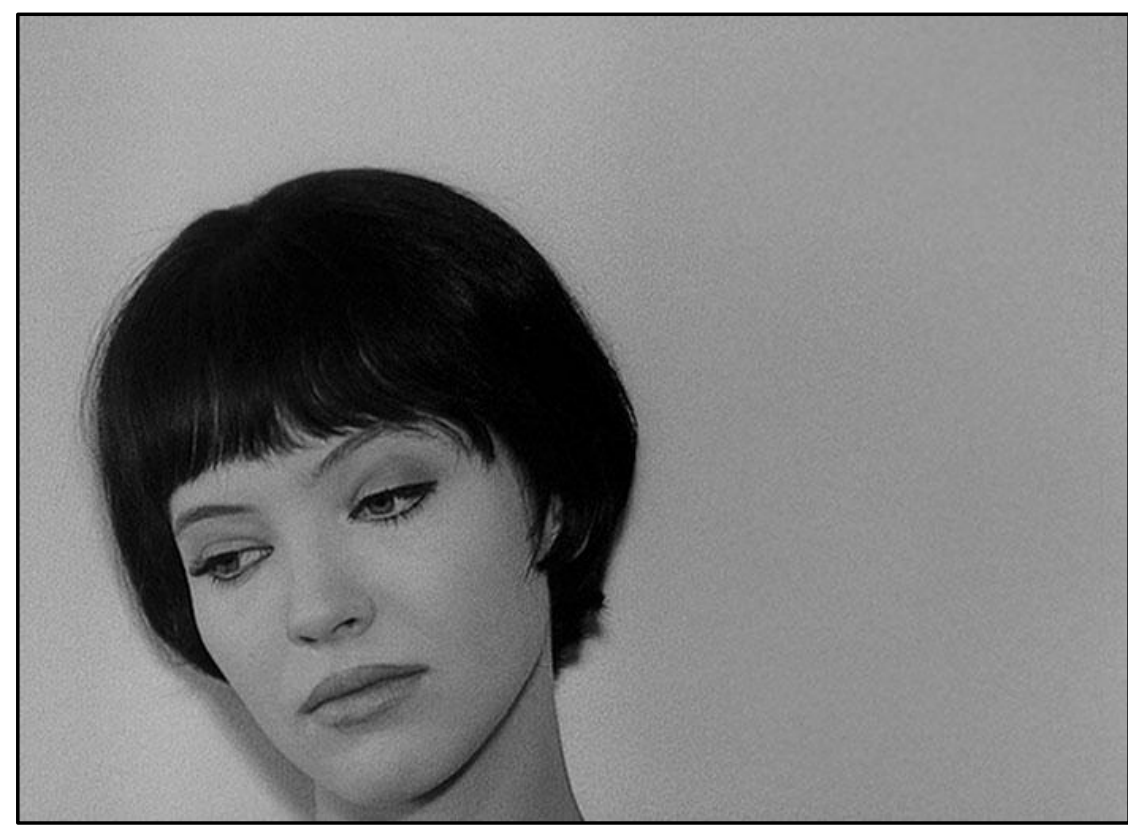

Figura 9: Exemplo de Primeiríssimo Plano - VIVER A VIDA (Fonte: Arquivo Pessoal)

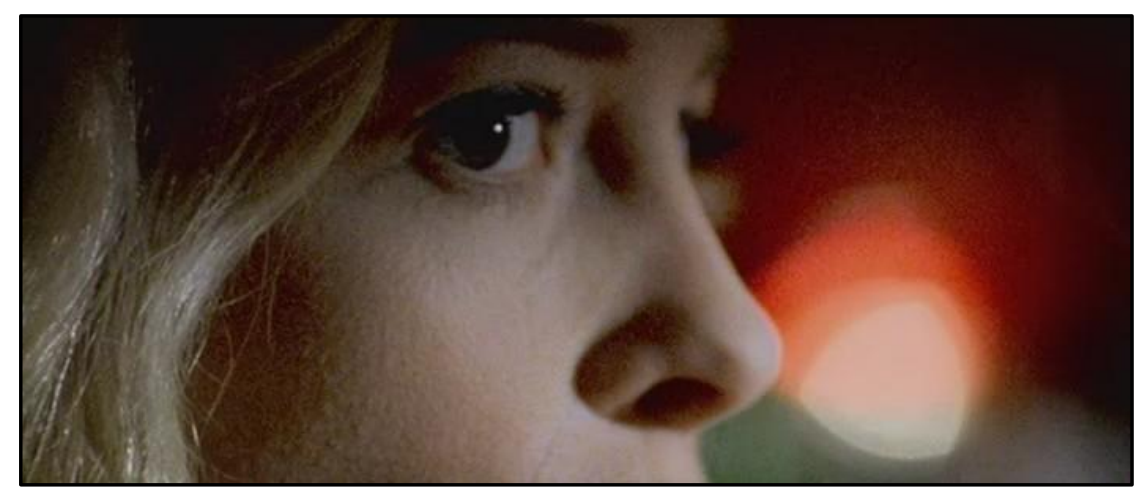

Figura 10: Exemplo de Plano de Detalhe - RECONSTRUÇÃO DE UM AMOR (Fonte: Arquivo Pessoal)

Com o estudo do espaço tendo sido feito, podemos pensar sobre o tempo cinematográfico, a partir da proposição de Debrix (1969) de analisá-los separadamente, embora seja da conjunção que eles existem. No cinema, o tempo é dividido em três tipos: o tempo físico, o tempo psicológico e o tempo dramático.

Sobre o tempo físico recai a ilusão aparente de que um filme reproduz perfeitamente a movimentação do mundo físico, mas, no entanto esses são fenômenos diferentes. Assim, a reprodução do movimento é bastante artificial, 
e o tempo pode ser imobilizado nos intervalos do fotograma, assim como pode haver variação de tempo dentro dos planos, ação acelerada, ação lenta, ação suspensa e retrospecto. São esses os elementos expressivos do tempo físico.

Com o tempo psicológico, o cinema retrata uma temporalidade que se aproxima mais do tempo de nossa vida mental do que física, que nada mais é do que um conjunto e mistura de passado, presente e futuro, com variações de duração, dilatação e digressão. O tempo psicológico é menos contínuo, menos previsível e menos inflexível do que o tempo do mundo físico. No cinema, através dos recursos de montagem e dos elementos espaciais, as mudanças do tempo psicológico podem ser facilmente utilizadas em transição. Suspense, Ritmo e Andamento são as qualidades expressivas do tempo psicológico.

Já o tempo dramático é mais complexo e está articulado diretamente à narrativa. É comum no cinema o uso de cortes para garantir uma condensação do tempo em que se exclui o "não essencial". Esta condensação pode ser efetuada no princípio ao fim, por conta do filme ser composto de centenas de frações de tempo reunidas em conjunto. Ralph Stepherson e J.R Debrix acreditam que essa possibilidade torna o cinema mais flexível e estabelecem, eles mesmo, uma comparação com o Teatro: "Sob este aspecto, o teatro vem-se tornando cada vez mais flexível pelo abandono de cenários complicados, e permitindo que mudanças de local ou tempo sejam representadas" E completam: "Mas, ainda assim, o teatro não é tão flexível quanto o cinema" (STEPHERSON; DEBRIX, ano, p. 114-115)

A junção tempo-espaço é possível mediante à montagem cinematográfica, e essa é a grande essência da linguagem do cinema. Ela é apresentada como a técnica e a característica predominante e central do cinema, pelo tratamento artístico que dá ao tempo e ao espaço, criando e determinando suas variantes: "Em um de seus livros, Eisenstein explica a montagem por analogia com os caracteres da escrita japonesa em que o todo é mais que a soma das partes." Por exemplo, "o símbolo japonês para 'cão', mais o símbolo para 'boca', juntos não formam 'boca de cão' - que seriam uma simples adição - 
mas um símbolo significando 'latido' - um novo conceito" (STEPHERSON, 1969, p. 36).

Diante da importância da Montagem, procurei identificar os princípios desta relação Tempo-Espaço e verticalizar. Portanto, no cinema:

- O espaço tornar-se dinâmico, carregado de tempo.

A câmera percorre e descreve um espaço e, ao percorrê-la, lhe dá mobilidade. Essa mobilidade é ilusória, do ponto de vista do 'real', onde o mesmo espaço é estático, não dinâmico.

- Parcelas de espaço compõem ordem e estrutura com ritmo temporal

$\mathrm{Na}$ transição entre planos, podemos identificar o ritmo de uma narrativa, por exemplo, de um plano médio para close-up o que equivaleria, em música, de um fraco para um fortíssimo.

\section{- Temporalização do espaço}

Trata-se de uma radicalização do tempo cinematográfico em detrimento do 'real'. No cinema, podem-se percorrer muitos espaços em pouco tempo ou mesmo um único espaço, um objeto, em um tempo estendido. O cerne dessa possibilidade está na montagem, pelo corte e é possível pela dinamização explicada no item $a$.

\section{- Há separação da Simultaneidade}

Os cortes nos mostram ações simultâneas em tomadas diferentes. A montagem dá para o espectador a chance de acompanhar eventos que no tempo 'real' ele não seria capaz. Na narrativa, ele é um observador privilegiado.

\section{- Sem continuidade Ininterrupta e Sem direção Irreversível}

O corte interrompe a ação e pode reverta-la. No 'real' a ação é sempre progressista, não há pausas e ela não retorna. Na montagem cinematográfica, com uso do retrospecto do tempo físico, pode-se alterar esses princípios do tempo. 


\section{- Espacialização do tempo}

Na espacialização do tempo, temos novamente um extremo em montagem. Podemos nos mover no tempo com passado, presente e futuro. É como se o tempo tornasse-se um espaço pelo qual a montagem nos leva a caminhar. É, portanto, a radicalização do item $e$.

Os elementos descritos até aqui são parte concreta da linguagem, são os meios pelos quais os artistas instalam e organizam sua mensagem. Do ponto de vista da intersemiótica, é preciso empreender-se em um estudo preciso e rigoroso das condições materiais que permitem que a instalação e organização da mensagem aconteçam, ou seja, que o cinema funcione. O objetivo é compreender e descrever de forma exata os processos de significação do cinema. Segundo Cristian Metz (1974) - apoiado em Charles S. Pierce e Ferdinand de Saussure - podemos chamar esse empreendimento de uma semiótica do cinema.

A Semiologia de Saussure é, em geral, a ciência do significado, muito aplicada à linguística, enquanto que a Semiótica de Pierce, nesse caso da cinematografia, propõe construir um modelo abrangente capaz de explicar como um filme adquire significado e o transmite ao espectador. Pela semiótica do cinema, quer-se determinar leis que tornem possível o ato de ver um filme e desvendar padrões particulares da significação que dão a filmes, autores e gêneros específicos seu caráter especial. Por exemplo:

\footnotetext{
O semiótico gostaria de descobrir as possibilidades gerais de significação de uma tomada de zoom, ao mesmo tempo também gostaria de conhecer a função particular que o zoom desempenha junto com outras técnicas nos, digamos filmes de Robert Altman. No centro do campo do cinema está o fato cinematográfico e no cerne do fato está o processo de significação. O semiótico penetra diretamente nesse cerne? (ANDREW, 2002, p. 173-174)
}

Com a interrogação deixada pelo pesquisador J.D. Andrew oriento minha pesquisa sobre o sistema cinematográfico. A resposta é afirmativa, pois embora os significados da linguagem cinematográfica não sejam fixos - assim 
como as cores em artes plásticas -, já que a sua compreensão se dá pela função e pelo conjunto, podemos decodificar a mensagem do texto fílmico encontrando seu significado e compreendendo a malha que temos a frente como um sistema próprio. É possível falar no sistema cinematográfico mas mais pertinente ainda é falar no sistema do texto, já que todo filme (texto fílmico) é a concretude de um embate com a linguagem e desse embate resulta um sistema próprio de significação, em suas dimensões metodológicas, históricas e sempre estéticas.

A decodificação, nada mais é que a leitura. Do ponto de vista da semiótica é preciso operar na leitura pelos códigos. A tradução é a forma mais completa e apropriada de ler, pois o artista-tradutor usa os códigos para ter acesso ao original, que na verdade é um original sempre seu já que a leitura é sempre individual, e a partir dessa leitura ele reorganiza os signos num sistema de transferência. É importante saber que a reorganização dos signos pode implicar também na criação de novos códigos, dependendo de qual atento e consciente o tradutor está nesse processo. Mas não são os únicos códigos do novo texto, visto que esse também será alvo de recepção, nova leitura.

\footnotetext{
Os semióticos falam infinitamente em códigos. Um código nada mais é que a relação lógica que permite que uma mensagem seja entendida. Códigos não existem em filmes; em vez disso, eles são regras que permitem as mensagens de um filme. São de fato construções dos semióticos que, depois de estudar grupos de filmes, formulam as regras em ação (os códigos) nesses filmes. Assim, os códigos tem uma existência real que não é uma existência física. Os códigos são o oposto dos materiais de expressão. São formas lógicas imprimidas nesse material para gerar mensagens ou significados. (ANDREW, 2002, p. 179)
}

O cineasta e o semiótico trabalham em direções opostas: o cineasta usa códigos pra fazer seu material falar para o espectador já o semiótico usa as mensagens de um filme para ajuda-lo a construir os códigos que transcendem essas mensagens. A questão da significação, muito presente em discussões e críticas sobre cinema, está centrada no que um filme diz, em sua mensagem: “o semiótico visa as leis que governam essas mensagens, a possibilidade do próprio discurso fílmico" (ANDREW, 2002, p. 175). O artista-tradutor faz e refaz esses caminhos, ele vai ao texto de partida, compreende as leis que governam aquela mensagem, escolhe signos por afeição e afetação, compreende 
a relação dos signos com códigos, tem material de criação, instala e organiza sua mensagem, há um novo texto que não quer repetir aquilo que o texto fílmico diz; em vez disso, espera isolar a seu modo, com sua técnica e em sua nova linguagem os mecanismos que permitem à matéria-prima expressar.

Embora muitos abordem as linguagens em comparação aos sistemas verbais, por conta da extensa teoria que sobre linguística, semântica e pragmática, essa comparação não cabe com o cinema. No cinema não existe a mesma forma de uso do sistema verbal. O cinema é um sistema de comunicação frágil, no qual todo uso pode ser poético ou inventivo, até o mais simplesmente prosaico. Segundo Andrew, de modo mais técnico, na linguagem verbal o nível conotativo de significado existe bem separadamente do nível denotativo. No cinema, não.

No cinema, a conotação vem junto com a denotação. Porque significante e significado são ligados tão intimamente, vemos a denotação de uma imagem ao mesmo tempo em que percebemos a atitude do cineasta com relação a ela. Na realidade, somos muito pressionados a distinguir uma separação entre esses níveis ou mesmo a estabelecer em uma imagem o que é denotativo e o que é conotativo. (ANDREW, 2002, p. 1778 - 1779)

Isso acontece porque, no cinema, os significantes são diretamente ligados aos seus significados: "Não é possível separar os significantes do cinema sem desmembrar seus significados ao mesmo tempo. [...] Apesar de alguns cineastas terem recorrido ao uso da cor nas cenas de tempo presente e branco e preto nas de tempos passados ou condicionais (sonho)", o autor acredita que “isto é claramente uma convenção sofisticada acrescentada ao cinema, e não um aspecto inerente à própria linguagem." (ANDREW, 2002, p. 176).

$\mathrm{O}$ ator-tradutor opera metodologicamente, como vimos anteriormente, pela (de)codificação. Entretanto, ele age também historicamente na tradução: "A história do cinema, para o semiótico, é nada mais que uma sucessão de soluções diferentes (subcódigos) para situações de codificação (interpretação, iluminação, perucaria, movimento de câmera e assim por diante)" (ANDREW, 2002, p. 175). O tradutor tem duas áreas de estudo e de prática, sendo elas: a) examinar e descrever tantos códigos quanto sejam os que lhe interessem e b) 
toda história do cinema; mas segundo o autor, é preciso também observar o destino de um código ao longo do anos, descriminando e descrevendo os vários subcódigos que lhe tornaram possível a existência.

\section{- $\underline{\text { AÇÃO 2: } 1^{\mathrm{a}} \text { REUNIÃO COM OS ATORES }}$}

Nesse encontro estavam Christiane Martins e Bruna Lima.

\section{a) PROCEDIMENTO 1: Experimento Livre com Linguagens}

\section{- Exercício 1: Artes Plásticas}

- Seleção variada de pinturas, estilos e épocas.

- Pinturas impressas e projetadas

- Atores explicam seu ponto de vista sobre a variedade.

- Cada ator escolhe uma pintura.

- O ator analisa a pintura por alguns minutos.

- Ele não experimenta a ação.

- Propóem por improviso uma cena que traduza aquela pintura.

- Debate com atores sobre quais os elementos escolhidos.

Com este exercício, os atores inicialmente apresentam sua própria organização sobre a variedade em Artes Plásticas, assim eles mesmos introduzem conceitos sobre estilo, contexto histórico, figurativo e abstrato, entre outros. As figuras mencionadas a seguir mostram parte das obras utilizadas durante a oficina e podem ser vistas nos anexos.

A atriz Christiane Martins escolheu a pintura The painter's family de Matisse (Figura 11). Sua cena consistiu em três micro-ações, com uso de transições para dar conta de traduzir as diferentes figuras pintadas, mesmo estando em solo. Em cada micro-ação, Christiane escolheu um momento em que fisicamente buscava chegar à mesma pose que cada uma das moças tinha. Quando nessa mesma posição, a atriz permanecia em alguns instantes em congelamento. Um trabalho com o estático. Com relação à transição, a sequência escolhida permitiu problematizar a dramaturgia interna da tela. 


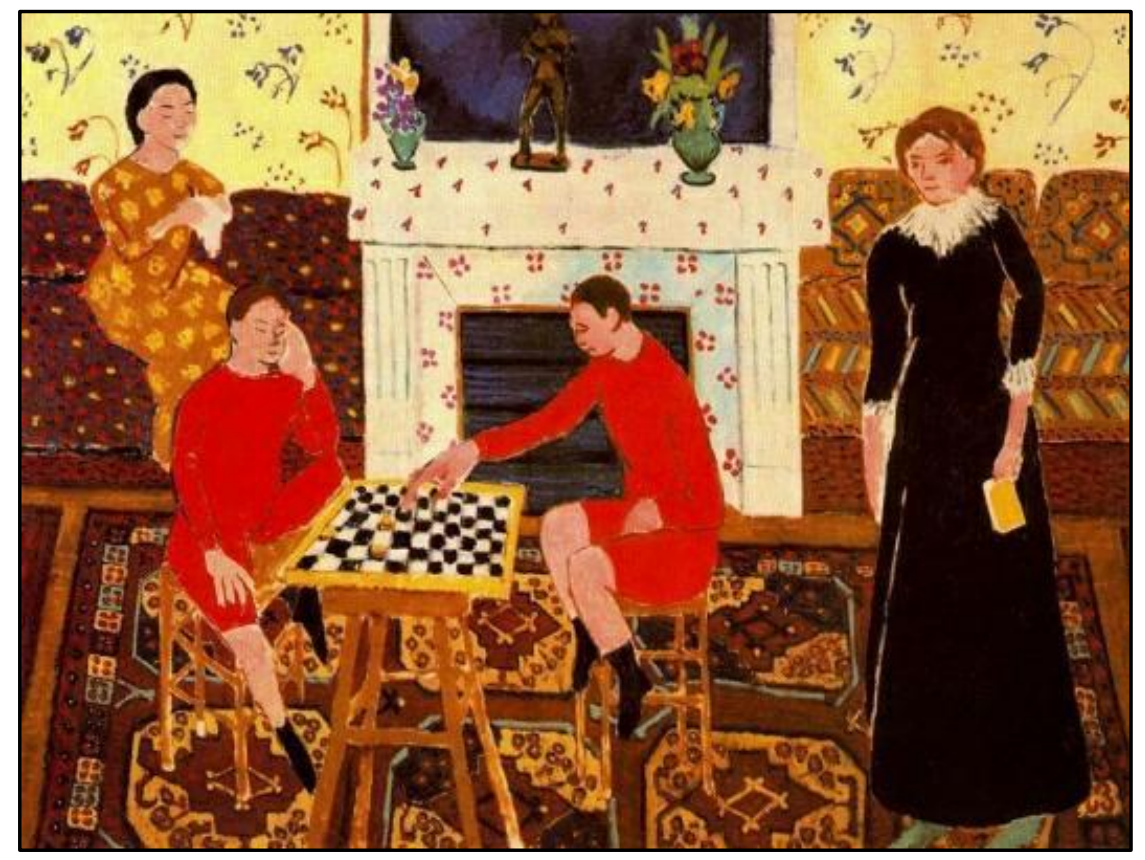

Figura 11: The painter's family - MATISSE (Fonte: www.abcgallery.com/M/matisse - em 06 ago de 2011)

Na cena da atriz Bruna Lima, vimos o exercício para a obra Sleeping Peasents (Figura 12), de Picasso, com demonstração da extensão do espaço cênico e problematização da presença cênica. Sobre o primeiro, o aspecto interessante foi o desenho das ações performadas antes de se formar o quadro de cena, ou seja, todas as ações físicas que permeiam a dramaturgia da pintura antes do congelamento daquela imagem.

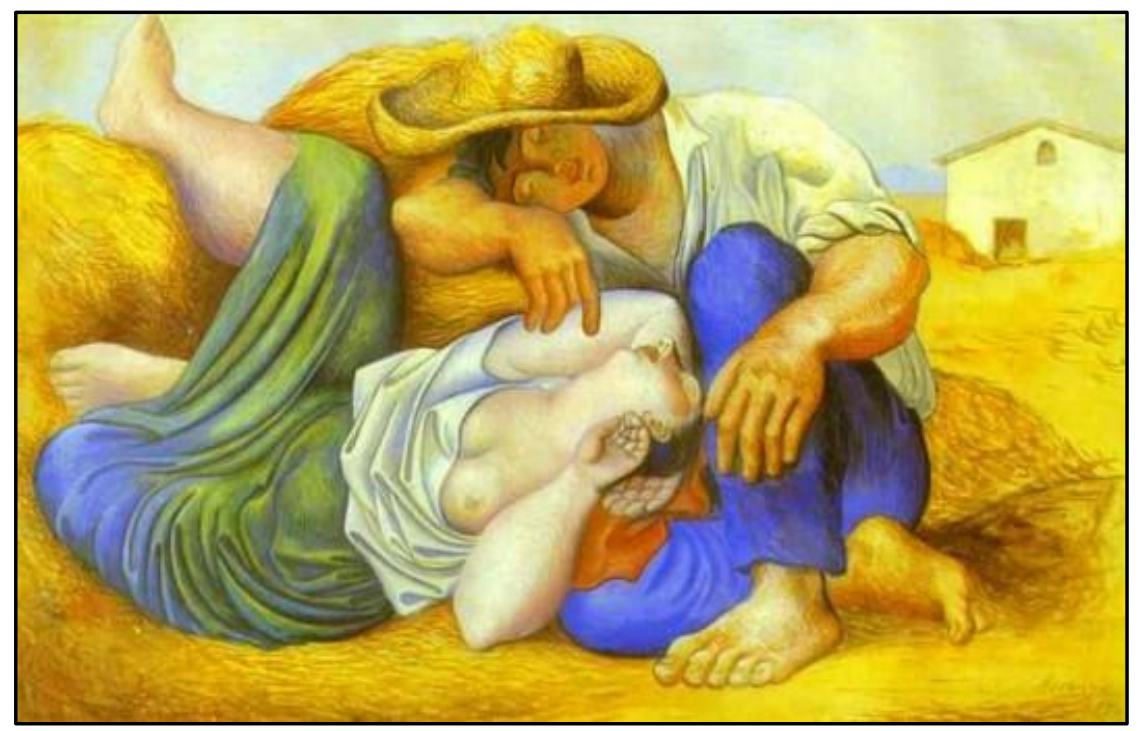

Figura 12: Sleeping Peasents - PICASSO (Fonte: www.abcgallery.com/P/picasso - em 06 ago de 2011)

No caso, Bruna ficcionou a partir do signo sono e do trabalhador, buscando uma caracterização para o trabalhador com os objetos livro e relógio. Suas ações foram orientadas pela figura feminina - como descrito por ela a 
seguir: “Da plateia, um relógio cai. Objetos caem: livro, carta, óculos formando um trajeto. Um corpo se arrasta. Deita "de barriga para cima". Coloca as pernas em cima de um lugar mais alto. Cruza os pés. Descansa.".

O maior signo para a junção entre o sono e o trabalhador camponês, juntamente ao seio, ela disse ser: o despojamento dos pés cansados. É importante que os primeiros exercícios sejam com bases intuitivas do artista para cada linguagem e sua relação expressiva com o tempo e com o espaço. Dessa forma, o ator demonstra o que em si já é afim ou sensível à aquela linguagem, busca um diálogo genuíno e improvisado com a tradução.

A demonstração das atrizes em cena mostrou o quanto das ações físicas de Eugene Barba está na raiz da dramaturgia do ator. Antes dos objetos, do desenho de luz, dos figurinos, enfim, da encenação, há algo que é muito orgânico e está no corpo, e é energia. Dessa forma, todos os elementos posteriores serão acrescentados por conta de real necessidade. As ações físicas,

por sua vez, exprimem que tanto mais expressividade quanto maior for a presença do estado cênico, no ator.

Com esta primeira prática e algumas reflexões com as atrizes chegam à conclusão que atrelado à investigação das linguagens, havia de se fazer um estudo sutil quanto à percepção do estado cênico, para que ele esteja em diálogo com a essencialidade de cada linguagem.

b) PROCEDIMENTO 2: Estudo do Estado Cênico

- Exercício 1: Exercícios de Sensibilização

O ator caminha pela sala, sentindo-se presente em tempo e espaço. Quando ele sente que perdeu este estado, retira-se da roda, podendo voltar depois.

- Exercício 2: Massagens de Sensibilização (ref. Augusto Boal)

- Exercício 3: Jogos Teatrais (ref. Viola Spolin.).

- Exercício 4: Estudo do Artigo Corpo Cênico, Estado Cênico

Na Pedagogia do Teatro se diz sobre pré-expressividade e expressividade, extra-cotidiano, organicidade (ou tornar orgânico), atenção, 
necessidade, tônus e energia para falar sobre este estado de alteração cênica. Nos encontros com o grupo nós lemos por indicação da atriz Bruna Lima o texto Corpo cênico, Estado cênico de Eleonora Fabião - Doutora em Estudos da Performance pela New York University e docente do curso de Direção Teatral da UFRJ.

Inicialmente, fiz uma leitura individual onde tentei identificar quais os princípios apontados pela autora e quais as práticas descritas direta ou indiretamente no artigo que poderiam ser elaborados como procedimento a experimentar com o grupo. De forma que foi possível identificar quatro eixos desta questão: Estado cênico, Corpo cênico, Ação cênica e Nervura.

Quanto ao Estado Cênico, discutimos sobre Fluxo e Atenção:

O fluxo abre uma dimensão temporal: o presente do presente. A capacidade de conhecer e habitar este presente dobrado determina a presença do ator. Perderse nos arredores do instante - na ansiedade do futuro do presente ou na dispersão do passado do presente - faz com que o agente se ausente de sua presença. A qualidade de presença do ator está associada à sua capacidade de encarnar o presente do presente, tempo da atenção. O passado será evocado ou o futuro vislumbrado como formas do presente. (FABIÃO, 2010, p. 322)

Por conta do fluxo, realizamos o jogo-exercício de identificar esse fluxo durante a caminhada e de o mantermos o máximo possível, dando uma pausa do jogo quando o perdêssemos. A manutenção desse fluxo dependia diretamente da Atenção:

\footnotetext{
O corpo cênico está cuidadosamente atento a si, ao outro, ao meio; é o corpo da sensorialidade aberta e conectiva. A atenção permite que o macro e o mínimo [...] possam ser adentradas e exploradas. [...] A atenção é uma forma de conexão sensorial e perceptiva, uma via de expansão psicofísica sem dispersão, uma forma de conhecimento. A atenção torna-se assim uma pré-condição da ação cênica; uma espécie de estado de alerta distensionado ou tensão relaxada que se experimenta quando os pés estão firmes no chão, enraizados de tal modo que o corpo pode expandir-se ao extremo sem se esvair. (FABIÃO, 2010, p. 322)
}

As indicações de Eleonora são indiretas para com os procedimentos, por conta da abertura que a autora dar para que se chegue a uma compreensão própria. A imagem dos pés enraizados sugeriu-me o exercício do Lume, 
chamado Raízes, que apliquei em ensaio. Juntou a esse exercício outro da relação do pé com o de vibração, do Corpo cênico:

A cena exacerba a condição vibrátil do corpo. Porque hiper-atento, o corpo cênico torna-se radicalmente permeável. Contra a ideia de corpos autônomos, rígidos e acabados, o corpo cênico se (in)define como campo e cambiante. Contra a noção de identidades definidas e definitivas, o corpo-campo é performativo, dialógico, provisório. Contra a certeza das formas inteiras e fechadas, o corpo cênico dá a ver "corpo" como sistema relacional em estado de geração permanente. (FABIÃO, 2010, p. 322)

Para manter a tensão vibrátil do corpo, deslocamos a atenção para os pés. No exercício, pedi para que as atrizes sentassem-se sobre cubos, fechassem os olhos e mantivessem a atenção nos pés, num fluxo de energia que nos unia. Repetíamos frases como: “o chão que eu piso, é o mesmo chão que você pisa", buscamos fazer dessa experiência algo genuíno, uma sensibilidade sobre a fluência de energia que trocávamos só por dividir o mesmo espaço. É uma experiência empírica. As atrizes relataram sensibilização e pertinência no exercício. É disto que trata o drama da sala:

Para ativar circuitos relacionais, o ator deve trabalhar tanto no sentido de aguçar sua criatividade como sua receptividade. Geralmente a criatividade é privilegiada em detrimento da receptividade, a força criativa em detrimento do poder receptivo. [...] A busca por um corpo conectivo, atento e presente é justamente a busca por um corpo receptivo. A receptividade é essencial para que $\mathrm{o}$ ator possa incorporar factualmente e não apenas intelectualmente a presença do outro. (FABIÃO, 2010 p. 323)

Seguindo nossos estudos, concluímos com um conceito próprio da autora, a Nervura. Sobre a nervura da ação, Eleonora diz sobre a corporeidade da ação e seus três elementos, a postura, sensorialidade e a conectividade. Ela apresenta três propostas que realizamos no ensaio:

Proposta 1: investigar as sensações posturais conforme sugerido pelo mestre Yoshi Oida - através do desenvolvimento da escuta do corpo; através da sensação de macro a micro alongamentos, torções, pressões, relaxamentos e transferências de peso; através de variações em eixos básicos: céu e terra (cimabaixo), oriente e ocidente (esquerda-direita) e passado e futuro (frente-trás); experimentar sensações posturais através de um diálogo atento com a força da gravidade. Proposta 2: ativar e ampliar sensorialidade - investir nas relações mais elementares de percepção e interação consigo mesmo, com o meio e com o 
outro através dos cinco sentidos: tato, audição, olfato, paladar e visão. Proposta 3: acelerar conectividade - acirrar os entrelaçamentos corpo-espaço, corpotempo, corpo-história, corpo-matéria, corpo-ideia, corpo-palavra, corpoobjeto, corpo-conceito, partes-do-corpo, corpos-uns-com-os-outros-e-uns-nosoutros... através de experimentações psicofísicas múltiplas. (FABIÃO, 2010, p. 324)

c) PROCEDIMENTO 3: Estudo sofre fusão tempo-espaço: Cinema

- Espacialização do Tempo

- Temporalização do Espaço

- Selecionar trechos que demostrem esses processos

- Cada ator escolhe um trecho exibido e soluciona em cena um dos processos

- Escolha de signos.

Para este exercício, foram exibidos o curta metragem Bumes d'Automne de Dimitri Kirsanoff e um trecho de Blow Up de Michelangelo Antonioni. Esses textos cinematográficos foram escolhidos porque ilustram respectivamente a espacialização do tempo e temporalização do espaço. Em Brumas de Outono o maior tratamento é dado à espacialização do tempo, pois a montagem permite que nós nos desloquemos nas dimensões do presente, passado e passado do presente. Este curta de 1928 é logo no início anunciado como um "poema cinematográfico", onde a ambientação poética parte de influências russas e é construída com chuva, névoa, folhas, carta, lareira e chaminé (Figura 13).

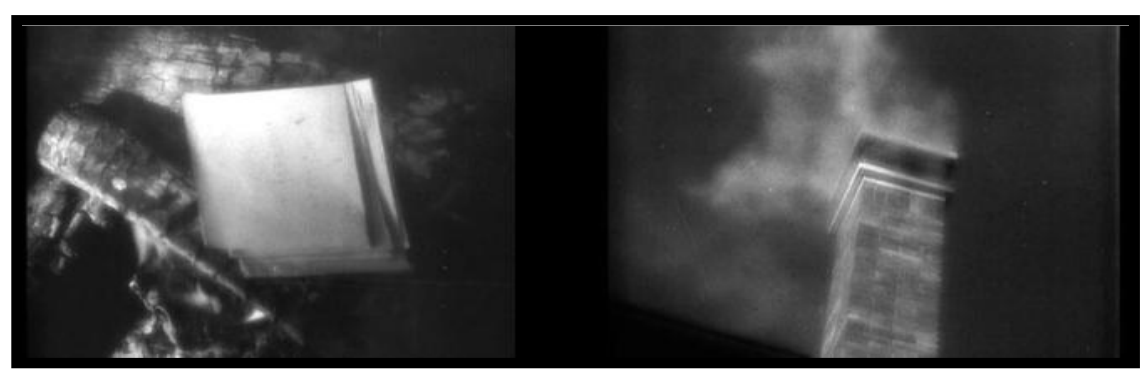

Figura 13: A Carta e a Chaminé - BRUMAS DE OUTONO (Fonte: Arquivo Pessoal)

Em Blow Up (Figura 14) - já uma tradução intersemiótica em si, pois foi baseado no conto do escritor Júlio Cortázar, Las Babas del Diablo - , a trama de um possível assassinato gira em torno de Thomas, um fotógrafo de moda londrino, que numa manhã registra um casal no parque da cidade. Jane, a mulher das fotos, reage com fúria e procura Thomas em seu estúdio para exigir 
receber os negativos. $\mathrm{O}$ trecho escolhido mostra a visita e demonstra a temporalização do espaço, pois se vê materializado no estúdio todo o labirinto e estranhamento estéticos presentes na obra de Antonioni.

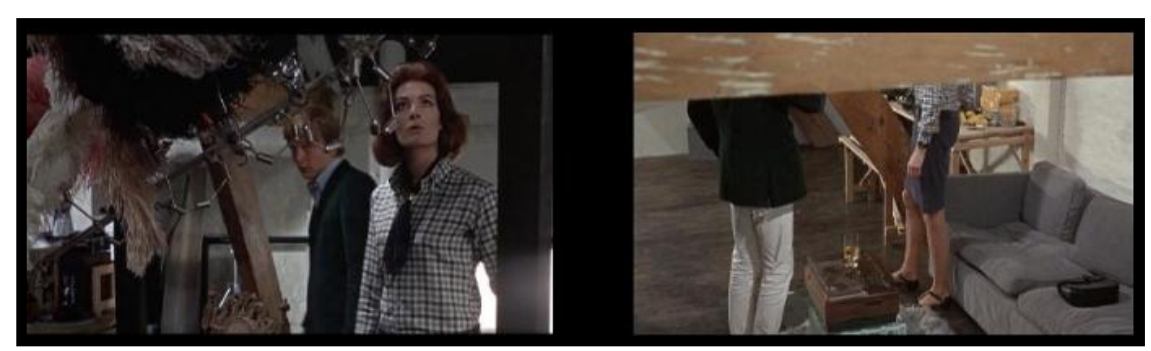

Figura 14: O espaço como Labirinto - BLOW UP (Fonte: Arquivo Pessoal)

d) PROCEDIMENTO 4: Demonstração de Trabalho

- Demonstração das cenas de cinema.

- Cada ator se posiciona sobre seu processo e é convidado a pensa-lo a partir dos princípios: Signos, Processo, Texto, análise de Poética própria.

Para este exercício, eu também propus uma cena. Notei que tempo e espaço estavam tornando-se mais presentes até na relação com a sala de ensaio, seu espaço e o tempo que ficamos nele. Escurecer a sala foi fundamental. Tanto pela projeção que gostaria de usar, mas, sobretudo para alteração de estado. Uma necessidade de duas vias: a de ser afetada por um novo ambiente e a de afetar o ambiente com uma condição que era interna e que muito tinha a ver com a escolha da obra de referência - a atmosfera melancólica de Brumas de Outono.

Como processo e procedimento, o cinema me fez pensar, sobretudo no ponto de vista do espectador, por conta do enquadramento, dos ângulos, dos planos e do corte, enfim, da montagem. Há uma tensão em organizar o espaço para que ele possa corresponder e transferir aquela técnica ao mesmo tempo em que a minha escrita no espaço seja com base na necessidade daquela ação e que, portanto não seja uma prisão pra mim. Com os objetos que já estavam na sala, fui aos poucos construindo a ambientação. No cinema, o apelo tecnológico é forte. Um deles é a trilha sonora. Muitos espectadores já relataram "assistir" a um filme, ou trechos dele apenas ouvindo aos sons - na sala de cinema ou na 
audição de sua trilha sonora gravada. Por isso, com auxílio de softwares, recortei a trilha e a usei na sonoplastia da cena.

Os signos mais evidentes e que considerei em minha tradução foram: a mão, a chuva, o fogo, a carta, o xale. É importante que na dimensão de signo eles sejam traduzidos não simplesmente como recolocados em cena. Por exemplo, o xale que a personagem veste em cena, não está apenas como um figurino, mesmo porque os estudos da indumentária já mostram a abrangência desse elemento. Na cena, ele serviu para ilustrar a passagem de tempo, entre o presente (ela lê a carta) para o passado (a visita e ida de um homem). A forma como o rearranjei - nas costas e como lenço - foi uma função simples da indumentária teatral mas que pode dialogar com a fade in/out cinematográfico. (Figura 15)

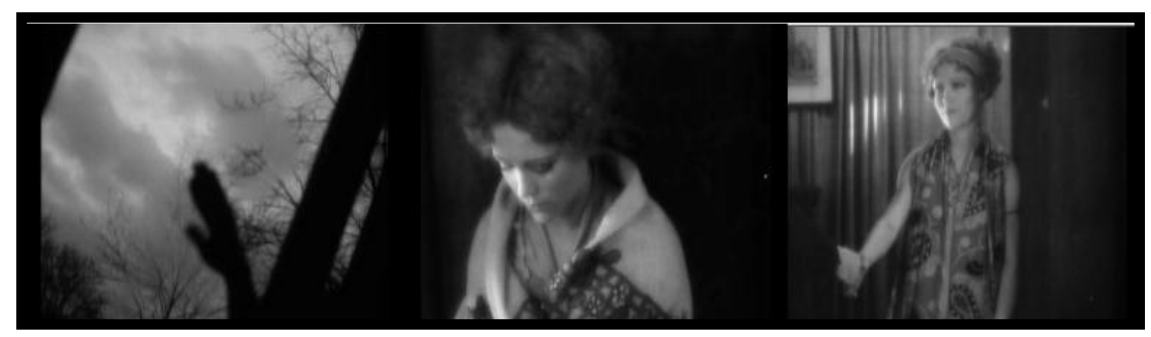

Figura 15: O Close na mão, a Indumentária e o Xale como espacialização do tempo - BRUMAS DE OUTONO (Fonte: Arquivo Pessoal)

e) PROCEDIMENTO 5: Estudo Teórico dos principais conceitos

- Workshop e Processo Colaborativo

- Tradução

- Diferenças entre Obra/Texto

- Signo

- Tempo e Espaço (Viewpoints)

Neste encontro, nós tivemos a primeira visita do encenador Fabiano Benigno para o qual os estudos dos principais conceitos foram uma introdução à pesquisa. Propomos a ele a condução do processo quanto ao treinamento do ator para a Fisicalidade. Ele dispôs a ficar conosco por alguns encontros, como preparador, e reassumir o processo adiante como encenador. 
Em relação ao estudo em si, notamos que ele trouxe clareza para os conceitos que estávamos usando, trouxe um vocabulário comum, sobretudo quanto a signo e texto. Desfizeram-se as dúvidas sobre tradução e mimetismo e concordamos em estudar o Viewpoints como uma abordagem para a relação tempo, espaço e composição. Os atores sugeriram termos uma pasta de textos em comum.

\section{f) PROCEDIMENTO 6: Escolha de Temas, Estéticas e Discursos}

- O grupo lista temas, estéticas e discursos que quer pesquisar.

Nessa etapa, após o estudo teórico e a lista de temas dos artistas, a oficina tornar-se mais direcionada, específica e aplicada aos interesses estético-criativo dos envolvidos. Mostra-se que a abordagem não privilegia uma técnica ou estética específica, mas que é uma ferramenta de criação para todos os artistas e suas diversas finalidades dramatúrgicas.

No grupo Dramaturgia do Ator os temas foram os seguintes: Bruna Lima (O Feminino, a Memória, o Poder, o Barroco, o Labirinto, textos de Samuel Beckett e Harold Pinter); Christiane Martins (Rotina, Cotidiano, os filmes Cenas de um Casamento, Os incompreendidos e O último metrô, textos de Nelson Rodrigues); Fabiano Benigno (o Expressionismo).

Propus que a Tradução Intersemiótica seria uma forma de abordar o repertório que cada artista já traz e uma forma de ler.

\section{g) PROCEDIMENTO 7: Experimentação livre de temática $/ 1^{\circ}$ Workshop}

- Cada ator leva seus textos (pinturas, músicas, filmes, textos, objetos) para o Workshop.

- Treinamento Físico de Fabiano Benigno.

- Cada ator apresenta um workshop.

- Cada ator elabora uma pergunta para si e para os outros workshops

- Debate sobre workshop livre e escolha de signos. 
Diante de um signo, o ator constrói outros signos interpretantes - signos cênicos, de interpretação ou de encenação, aos poucos se vê uma malha de signos que é a própria dramaturgia. Nesse encontro foram produzidos quatro workshops, um a mais do que o habitual, pois tivemos a entrada de mais um atriz no grupo: Áurea Barros, aluna da Escola de Arte Dramática.

Começamos o encontro pelo treinamento de ator dado por Fabiano Benigno que teve o intuito de um trabalho físico, corporal, com a musculatura das costas, citando Eugene Barba, ao falar sobre a origem das ações reais na dramaturgia do ator: "Essas 'pequenas formas dinâmicas' para que sejam ações reais, devem necessariamente ter origem na espinha dorsal e se irradiar por todo o corpo, alterando sua tonicidade muscular" (BARBA, 2011, p. 16).

Seguindo a mesma instrução dada aos atores no encontro passado, Áurea trouxe seus elementos textuais para propor uma cena que mostrasse a confluência das linguagens, na tradução. Irei detalhar dois workshops, o dela e o meu, para comparar duas leituras para o mesmo exercício, em etapas de estudo distintas, pois diferente de mim que estava participando desde o começo, ela acabara de chegar. Meu workshop chamava-se Um beijo roubado (2008), pela referência direta ao texto que eu tivera dado maior foco: o filme homônimo de Won Kar Wai, para o qual posteriormente elaborei um roteiro de ações:

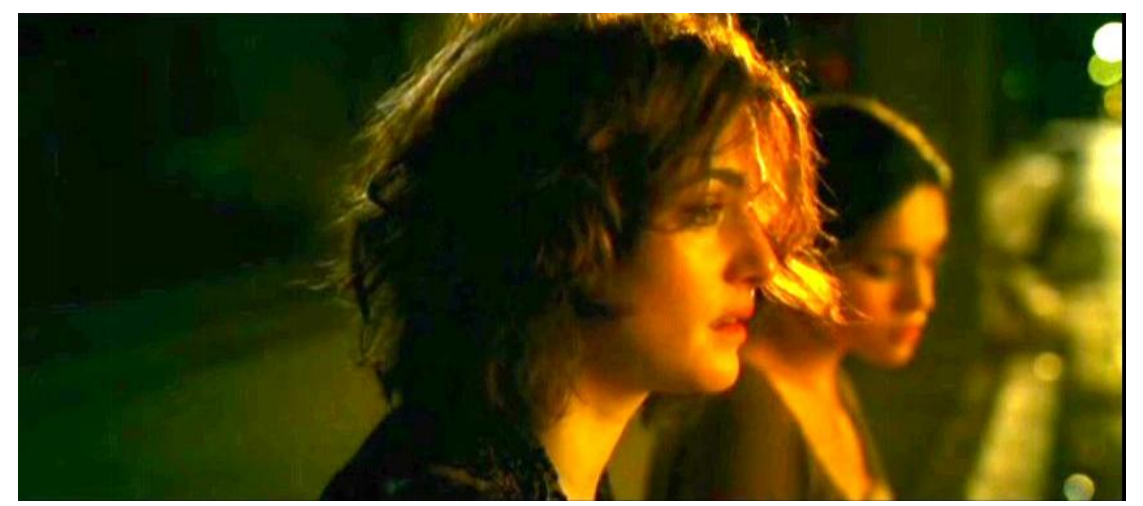

Figura 16: My Blueberry Nights - WON KAR WAI (Fonte: Arquivo Pessoal)

1. Levanta-se da plateia. Caminha de costas para o espectador, diagonal.

2. Há um painel com uma foto projetada. Uma moça em lateral.

3. Coloca um vestido, no canto do painel.

4. Posiciona-se em plano médio em frete à foto, também em lateral. 
5. Coloca um batom no chão.

6. Movimentos de quadril, encaixe de costas - procedimento de Fabiano Benigno.

7. "Foi ali que a gente se conheceu. Eu estava alta como uma pipa. Você tem bebido moça? Aí eu sorri."

8. Passa o batom nos lábios. Vira-se de frente para o espectador.

9. "Foi ali que a gente se conheceu. Eu estava alta como uma pipa. Você tem bebido moça? Aí eu sorri."

10. Olha o espaço da sala. Há objetos nele. Reorganiza-os. Vira-se para o público. Sente-se vista

11. Reorganiza os objetos compulsivamente, repete: "Foi ali que a gente se conheceu", "Foi ali".

12. Senta-se novamente na plateia.

13. Repete para um espectador ao seu lado, apontando para a foto: "Foi ali que a gente se conheceu. Eu estava alta como uma pipa. Você tem bebido moça?" Sorri.

Para o workshop, entrei em cena com uma pergunta em mente: “Qual a minha presença?", que revela ao mesmo tempo uma preocupação artística e técnica - um reflexo dos estudos sobre Estado Cênico - mas que ao mesmo tempo dialoga com o discurso dos filmes escolhido, já que My Blueberry Nights trata também da dualidade presença-ausência ao longo da narrativa. (Figura 16)

Para mim, a atriz Christiane Martins elaborou a pergunta: “De que tenho saudade?", pois acredita que minha leitura evidenciou um discurso tangencial no filme sobre Nostalgia, representado na foto que escolhi projetar. (Figura 17)

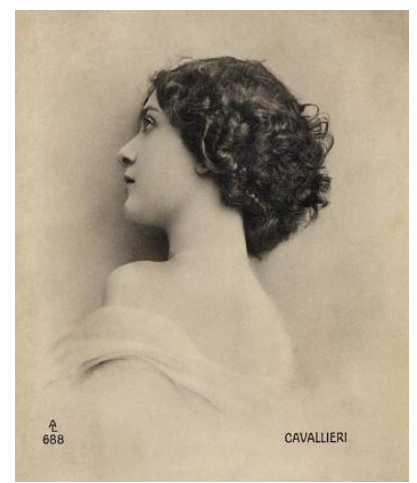

Figura 17: Imagem projetada em workshop - NOSTALGIA (Fonte: Arquivo Pessoal) 
h) PROCEDIMENTO 8: Workshop Orientado: Artes Plásticas I

- Cada ator leva uma pintura que dialogue com sua pesquisa pessoal (tema Feminino).

- Treinamento Físico de Fabiano Benigno - Espaço.

- Apresentação dos workshops.

- Transcrição das cenas, em roteiros.

- Debate sobre escolhas, signos, poética própria.

- Debate sobre pintura como Tradução e não como estímulo.

Esse foi o primeiro workshop elaborado após a orientação dos estudos da Tradução Intersemiótica. A divisão em linguagens permite que haja uma verticalização das possibilidades de tradução e inter-relação específica.

Nesse encontro, quatro cenas foram apresentadas: Christiane Martins ( $A$ bailarina Löie Fuller vista dos bastidores - A Roda, de Toulouse-Lautrec), Bruna Lima (Nascimento de Frida Kahlo), Áurea Barros (O grito de Edward Munch) e o meu, Brenda de Oliveira (As damas d'Avignon, de Pablo Picasso). (Figuras 18, 19, 20 e 21)

O principal questionamento que ficou do estudos das artes plásticas foi dos desafios de dar vida ao estático, mas que ao mesmo tempo era pulsante de movimento, pois fixava momento que considerávamos situações dramáticas pulsantes.

A essencialidade das artes plásticas para as artes cênicas que nós identificamos estava não apenas em dar mobilidade para a pintura mas de testar o valor estético da imobilidade em cena. São dois opostos que estiveram presentes nos workshops. De um lado, algumas cenas buscavam um movimento veloz e crescente, como de Bruna e Christiane, enquanto outros iam da ação à suspensão, da Áurea e meu.

O tratamento com o signo também variou e confirmou a possibilidade de poéticas de tradução que já sondávamos. Bruna escolheu o signo figurativo do feto em Nascimento para fazer um estudo sobre um corpo-animal, tecnicamente apoiou-se nos vetores de movimento da ação física. Sua leitura foi no sentido do 
nascimento como continuidade, mas ao mesmo tempo sempre um índice de morte. De corpo nu, ela estilizou o lenço pintado para encobrir o rosto da mãe de Frida Kahlo, como uma máscara. Com seu uso, ela pode explorar a alteração de estado que a máscara dá.

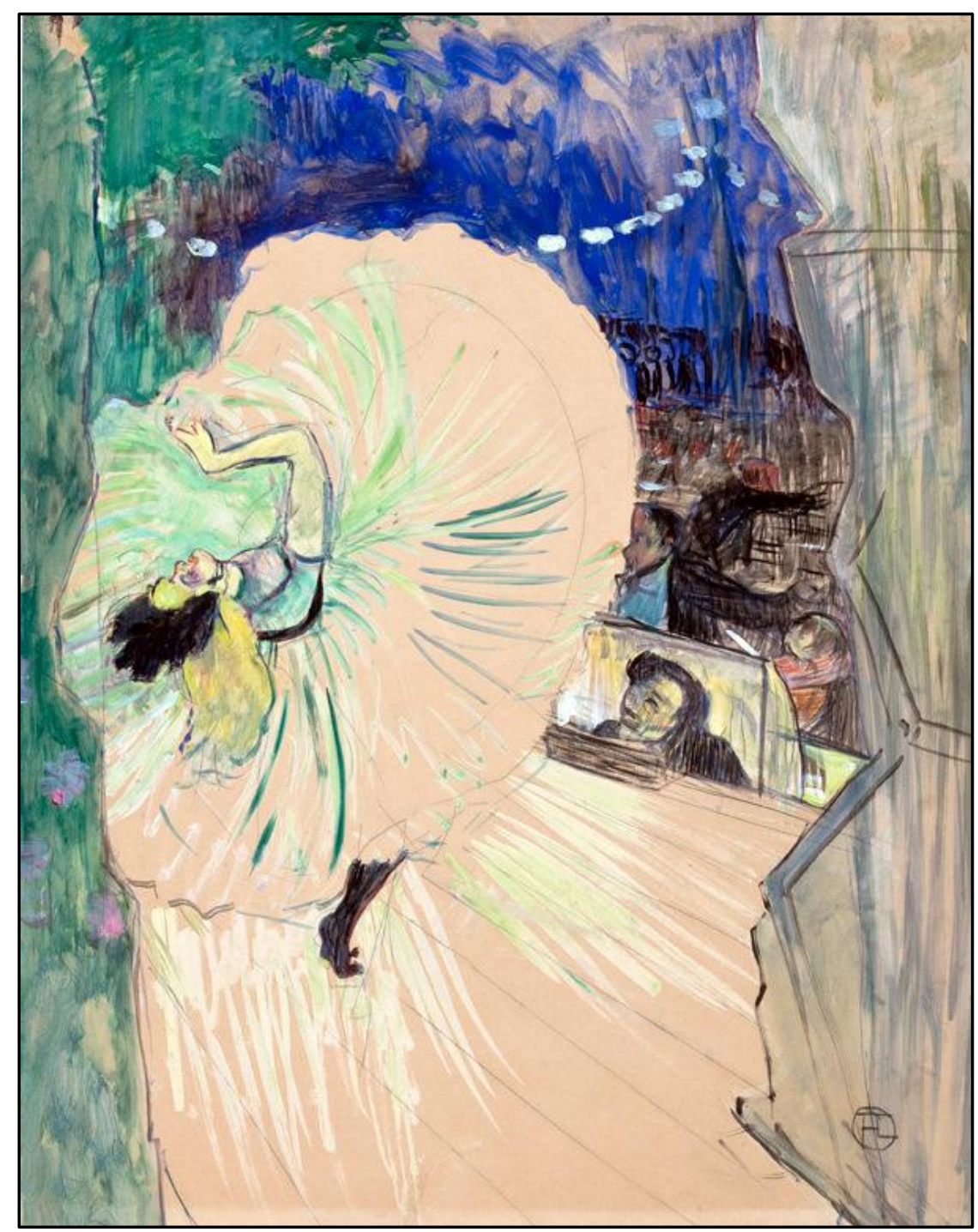

Figura 18: A bailarina Löie Fuller vista dos bastidores - A Roda - TOULOUSE-LAUTREC (Fonte: www.abcgallery.com/T/toulouse-lautrec/ em 08, ago de 2011)

O tratamento com o signo também variou e confirmou a possibilidade de poéticas de tradução que já sondávamos. Bruna escolheu o signo figurativo do feto em Nascimento para fazer um estudo sobre um corpo-animal, tecnicamente apoiou-se nos vetores de movimento da ação física. Sua leitura foi no sentido do nascimento como continuidade, mas ao mesmo tempo sempre um índice de morte. De corpo nu, ela estilizou o lenço pintado para encobrir o rosto da mãe 
de Frida Kahlo, como uma máscara. Com seu uso, ela pode explorar a alteração de estado que a máscara dá.

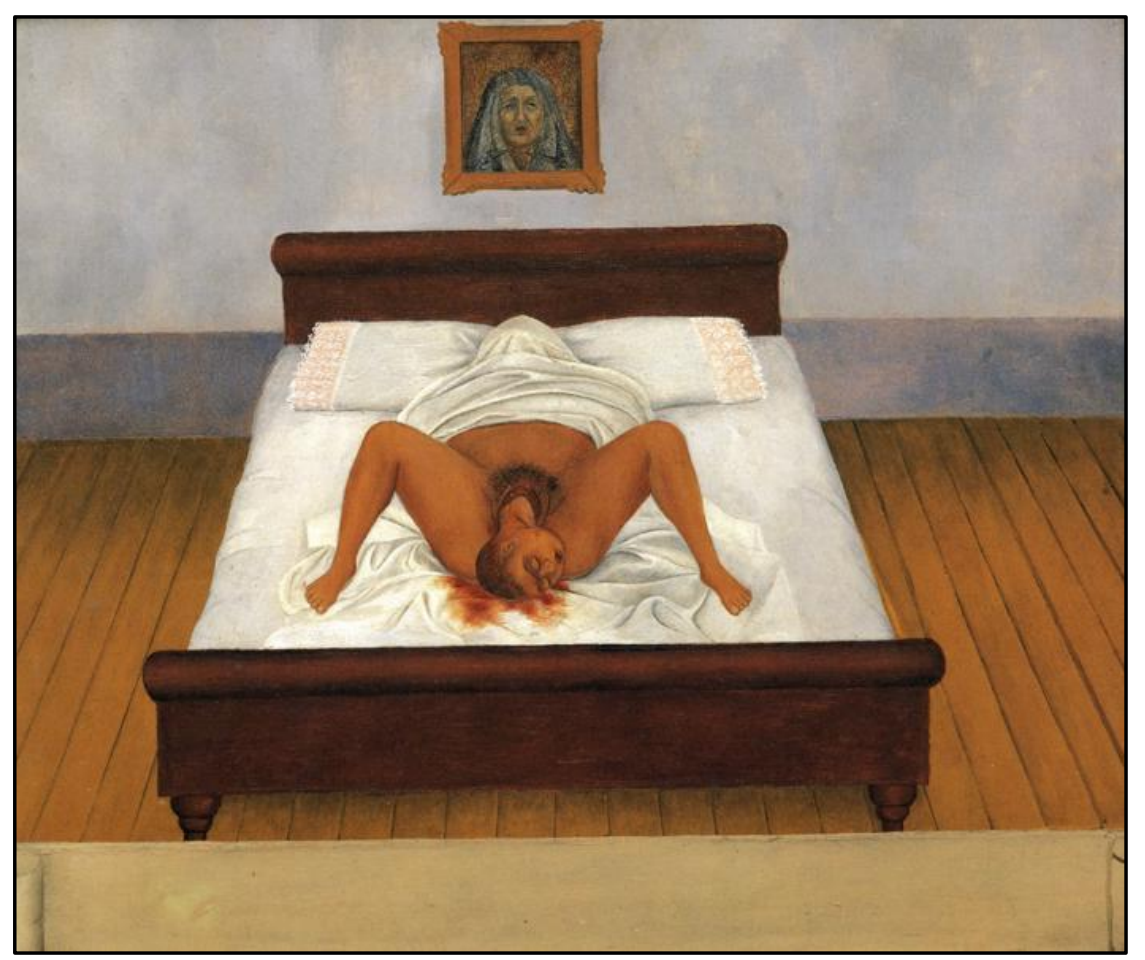

Figura 19: Meu nascimento - FRIDA KAHLO (Fonte: te: www.abcgallery.com/K/kahlo/ - em 08, ago de 2011)

Christiane, com A Roda (Figura 18) propôs uma movimentação pelo espaço redesenhando a precisão dos traços de Toulouse-Lautrec. Ela utilizou o signo da roda, representado pela saia da bailarina e seu movimento estava em utilizar essa saia para criar o efeito da roda. Sua ação também tinha o mesmo crescente que se viu no workshop anterior: do estático ao móvel.

No workshop da Áurea, o signo foi significado pela dimensão histórica, pois foi atualizado para uma situação cotidiana. Sua ação consistia em uma mulher que diante de um espelho, desconfigurava o rosto. As mãos deslizavam pela face, puxando-a para baixo. Inicialmente o movimento era intenso e veloz, e assim ia diminuindo a intensidade e o tempo, até congelar com a imagem da pintura.

Subitamente, ela dava um salto mudando de posição, antes estava de joelhos no chão e em seguida ia para o plano médio, usando salto alto. Sua próxima ação era olhar as unhas como se estivesse em um salão de beleza. Áurea usou o signo do grito para significar as questões femininas de estética e o 
seu peso social, como se o grito fosse uma digressão interna para aquela situação social e dramática que ela retratava.

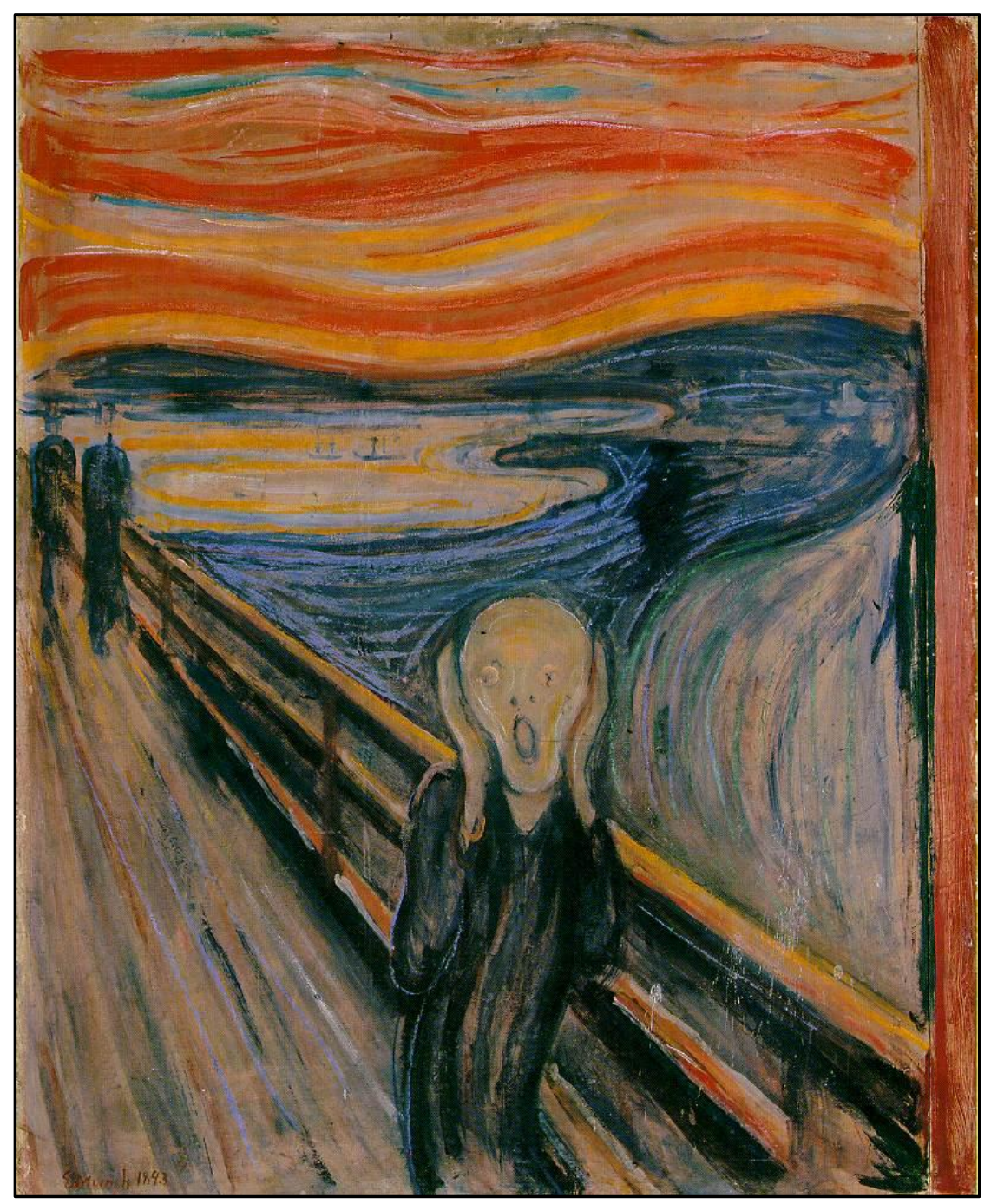

Figura 20: O grito - EDWARD MUNCH (Fonte: www.abcgallery.com/M/munch/ - em 08, ago de 2011)

Em meu workshop, busquei a transição entre as mulheres pintadas por Picasso. Percorri o espaço, desenhando um quadrado e em cada lateral eu desenvolvia um gesto para cada figura. A transição era rápida, com movimentos que a tornasse imperceptível, mas buscava uma suspensão em cada nova imagem para representar cada dama.

Como signo, usei a representação feminina como dama e busquei diferentes significados para cada imagem, associando o traço de Picasso a deformação característica do cubismo, a partir de uma leitura intuitiva. Utilizei também o lenço branco, ora como figurino, objeto cênico, ora como máscara. 


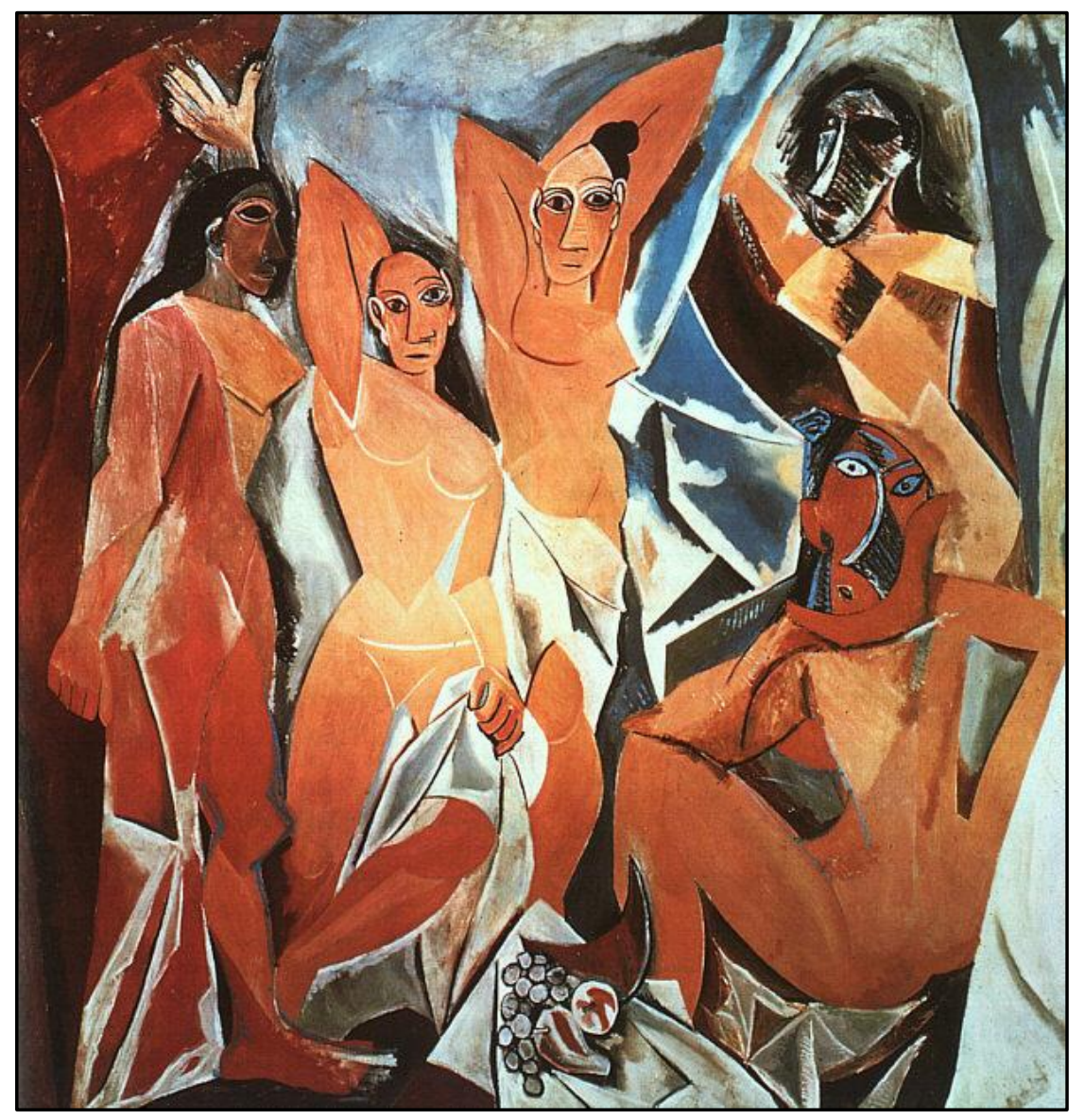

Figura 21: As damas de d'Avignon - PICASSO (Fonte: www.abcgallery.com/P/picasso - em 08, ago de 2011)

i) PROCEDIMENTO 9: Workshop Cinema 1

- Aquecimento Viewpoints (todos os princípios)

- Cada ator escolhe e leva um trecho de filme

- Cada ator leva elementos (objetos, figurinos, textos) que dialoguem com a cena

- Elaboração do workshop a partir dos resultados obtidos na experimentação

- Debate com atores sobre signos

- Debate com atores sobre fusão tempo-espaço

A principal questão da Pedagogia do Ator com relação às escolhas de Artes Plásticas e do Cinema, para além da elaboração e encenação da dramaturgia do ator, é a sensibilização para o espaço e o tempo cênicos. O tempo, já está presente no desenvolvimento da tradução intersemiótica para o cinema, devido ao movimento que é base da ação cênica e também pelo tempo estar latente no potencial de mobilidade imóvel da pintura. O cinema, é o momento em que a 
conjunção de espaço-tempo está mais presente, assim, na cena essa relação tende a se tornar mais evidente.

Os atores escolheram suas cenas com o rigor dessa observação, articulando as questões de linguagens sempre à sua pesquisa pessoal. Nessa etapa, os atores começam a atentar mais para a encenação, que um acabamento dado à ação física. Portanto, além do material de estudo, os textos fílmicos, eles começaram a utilizar objetos cênicos, como uma necessidade de tradução dos signos escolhidos e uma melhor forma de atender às necessidades da linguagem, como por exemplo, a vontade de traduzir uma cena, em que a ação é enquadrada em contra plongée, ou seja, de baixo para cima, trouxe a necessidade aos atores de terem uma cenografia que os deixassem mais altos, em certo nível do palco, ou da sala de ensaio. Na ausência de uma cenografia mais elaborada, os atores usavam cadeiras, cubos ou arquibancadas de madeira, que são recursos próprios da cenografia teatral mas que dialogam direto com a linguagem cinematográfica e, pela visão dos atores, poderia proporcionar a mesma sensação do olhar para o espectador, além de alterar o próprio estado do ator e lhe promover diferentes desafios de mobilidade e ação cênica.

Pela conjunção espaço-tempo ser vai evidente e sensível no cinema, os atores comentaram sobre a necessidade de um estado cênico mais apurado. No entanto, a atriz Áurea Barros, por exemplo, acredita que essa sensibilização pode ser acessada e localizada através do estudo das técnicas de teatro. Ela cita um texto do professor Antônio Januzelli, que traz a questão sobre “estar onde se estar", se o ator está onde está no espaço e no tempo presente.

Assumir a coordenação do estudo, sem estar em cena e começamos com a exibição dos trechos que os atores trouxeram. Primeiro estudaríamos a linguagem, depois iríamos ao treinamento físico, finalmente proporíamos um workshop seguido de debate. É nessa ordem que irei dissertar.

Inicialmente, a atriz Christiane Martins exibiu Fahrenheit 451 (1966) do cineasta François Truffaut, precedida de uma introdução que ela mesmo fez sobre o filme. 
É uma história no futuro, no qual os livros foram banidos da sociedade: é proibido ler. Então, algumas pessoas leem escondidas e (nessa cena) essa é uma senhora que tem livros escondidos e a função do bombeiro mudou, pois eles são chamados para incendiar os livros. Assim, todas as casas que tinham muitos livros, eram queimadas. No caso, nessa casa da senhora, que era uma casa antiga, não tinha nenhuma das tecnologias, é considerada uma casa condenada. Entretanto, um dos bombeiros, provavelmente o bombeiro-chefe, começa a se interessar por esses livros e começa a ler escondido. [...] Existe um pedaço da cidade, um refúgio, onde as pessoas vão para lá ler e cada uma se torna um livro, elas guardam na memória a estória, então cada pessoa se torna um livro" (CHRISTIANE)

A cena que a atriz trouxe era o momento exato em que os bombeiros chegaram para incendiar os livros e a casa toda, por estar condenada. Simbolicamente, o título do filme "Fahrenheit 451" é uma referência à temperatura em que os livros queimam. Nós assistimos ao trecho. Logo, todos comentaram que se tratava de uma cena muito difícil de traduzir intersemioticamente, mas ao mesmo tempo foi considerada por todos como tendo muitos signos, que listamos: o fogo (Bruna), os títulos dos livros escolhidos que aparecem em cena (Christiane), a foto da capa do último livro, pois há foto de um rosto que queima (Áurea).

O filme escolhido pela atriz Áurea Barros foi Irreversível (2002), do cineasta XX. Nesse filme há uma inversão do tempo dramático, pois se passa do acontecimento final ao inicial. A atriz comentou não ter terminado de assistir o filme após a cena que é considerada principal no filme, em que a protagonista sofre uma agressão sexual. Áurea comentou que a partir da leitura de sinopses, informou-se sobre o final do filme e, portanto a partir do estudo da tradução intersemiótica para o cinema, seria inclusive um desafio continuar a assisti-lo. Há outras relações que foram estabelecidas para a escolha.

Assim, a atriz escolheu o signo da gravidez como o que melhor explicita o desenvolvimento da narrativa pela linguagem, já que a cena principal do filme - a cena da agressão - é que separa esses dois momentos de antes e depois da gravidez. Pela experimentação, a atriz buscaria um corpo-nulo e a partir desse corpo, outro texto iria surgir carregado de outras simbologias, como a "herança" dessa violência. As outras atrizes do grupo fizeram observações de que havia contradições com a narrativa apresentada no filme e a leitura que ela 
propunha, pois a gravidez não era consequência da violência, já que a protagonista iniciava o filme estando grávida do marido, e com a violência o desfecho tinha sido outro: ela havia sofrido um aborto.

\begin{abstract}
É algo que tem me instigado, desde que eu li o texto da Maria Rita Kehl sobre ressentimento político: a política do ressentimento. Eu fiquei pensando em trazer não a mulher que foi violentada, mas a filha. Pensando no que se perdeu. Como trazer para cena esse agressor? Pois já está tudo ali, ele (o autor) já deu todos os caminhos. E falando sobre a pesquisa, fiquei pensando em trazer para o corpo aquela experiência do corpo anulado, e trazer o corpo anulado para a cena. Mas pensando nisso como uma partitura que vai me impulsionar, pois a única experiência que eu trouxe do filme foi a cena da violência, nada mais. Na minha cena não vou mostrar ao construir, pois a intenção é não mostrar. Quero mostrar o que essa figura que nasce carrega desse acontecimento. (ÁUREA)
\end{abstract}

Já que falamos bastante sobre o significante e a significação da gravidez, como signo escolhido pela Áurea, nós retornamos ao filme da Christiane pra listar os signos que ela escolheu: a palavra (a via negativa da palavra), o fogo (chama). O que para ela resulta em uma significação maior de "queimar a palavra", "queimar o discurso". Após listar, comentamos sobre o lado extremamente figurativo do cinema, do direcionamento do olhar, dos enquadramentos e os signos que a Christiane escolheu, vimos o quanto da linguagem estava no processo de significação, já que tanto o primeiro plano ou o plano próximo eram usados para enquadrar o fogo, a chama, os livros, a querosene. Outro elemento importante é a contagem de tempo. Para dar início ao incêndio, os bombeiros abre uma contagem de tempo em dez segundos decrescentes. Essa contagem, na montagem, é uma sequência de planos close, close-up e extreme close-up o que relativiza as tensões e importâncias narrativas, em si, mesclando tempo dramático e tem físico, cinematográfico e 'real'.

Começamos o treinamento físico com o auxílio de exercícios do Viewpoints por relação espacial. Após um breve aquecimento, as atrizes caminharam pelo espaço, buscando uma relação com a arquitetura concreta do teatro onde ensaiávamos tudo que o compõe, atentar para as linhas que o espaço tem e a disposição que elas ocupam. Nessa primeira instrução, as atrizes podiam aproveitar na corporeidade do espaço teatral em detrimento do 
cinematográfico, onde o espectador não pode interagir pelo tato, dessa forma as atrizes poderia tocar nos objetos presentes, caso sentissem necessidade. E esse tato, poderia ser, na verdade, um contato de todo o corpo com o ambiente.

Separadamente, os Viewpoints, dividem-se em categorias do tempo (Tempo, Duração, Resposta Sinestésica e Repetição) e espaço (Forma, Gesto, Arquitetura, Relação Espacial e Topografia). Continuamos com topografia, onde as atrizes cruzariam o palco, de ponta a ponta em linha reta com movimentos de no máximo noventa graus. Elas estavam paradas em pontos do palco, após a partida sonora dada, as atrizes deslocavam-se com a orientação de que a energia era como se estivessem em cena. Retiramos a marca sonora e elas continuaram a movimentação, buscando variações temporais e rítmicas. Saímos progressivamente da linha reta, contornando o espaço em qualquer direção, a orientação era manter as variações de tempo e as pausas, como "cortes".

Quanto à forma, as linhas que estavam no espaço foram transferidas para o corpo. É importante dizer que essa retomada se dá também em função da simbologia que já foi selecionada no cinema, portanto a experimentação técnica se dá em relação a esse universo de afetação. De forma, evoluímos para gesto, que é uma forma com atribuição de significado. Retomando os sinais sonoros, as atrizes alternavam entre os gestos que elas haviam chegado pela resposta sinestésica. Os gestos eram traduções dos signos através da ação física, com forma e tempo, o gesto trazia conflito.

Após o treinamento, as atrizes continuavam sua experimentação específica para a linguagem propuseram seus workshops. A primeira cena, de Christiane, teve uso da projeção do filme escolhido, ela movimentou-se e utilizou gestos criados durante o treinamento. Usou fósforos que estavam espalhados pelo teatro e para marcar a contagem de tempo, os acendeu. Para o momento de queima, utilizou espelhos e refletiu a imagem projetada pelo teatro, criando um efeito de que o teatro estava em chamas.

Para a atriz Bruna Lima, a cena de Christiane Martins tinha os registros da topografia que ela experimentou, pois a movimentação linear lembrou uma maquinização que o filme indica. Bruna acredita que o uso do fósforo cria a 
tensão da contagem regressiva, embora ela acredite que possa ser interessante experimentar a tradução sem a projeção do filme. Ele ressaltou o fato de a atriz em solo ter que lidar com a ausência dos outros personagens e dos outros elementos, por isso é importante delimitar um ponto de vista, um direcionamento do olhar para poder construir os outros. Christiane escolheu o ponto de vista do bombeiro, para que a transferência fosse feita, através do fogo.

A segunda cena, de Áurea Barros, também teve uso de espelhos. Ela usou para criar vários ângulos das ações físicas que ela desenvolvia, de costas para o espectador. As mudanças de formas e gestos aparecem quando ao passar diante de cada espelho sua cena expressava transição, entre personagens, foi uma solução encontrada para os elementos técnicos da linguagem, como enquadramento e ângulo de câmera, mas também para solucionar a ausência dos outros personagens na narrativa, já que em cada transição, um novo ser ficcional estava em cena.

Os comentários começaram por Bruna Lima que disse a tradução foi orientada por signos que estavam indicados. Para ela, o discurso em cena retomava a questão da feminilidade onde cada espelho mostrava um ângulo dessas mulheres. Com a fala final, o texto dito pela atriz, Bruna localizou o uso da repetição como característica temporal.

No geral, por conta da conjunção espaço-tempo, houve dificuldades em traduzir a linguagem cinematográfica. Áurea: “Achei muito difícil utilizar a linguagem do cinema, porque se você pensar, tudo está fechado. O corpo dela é fechado, o olhar que ele conduz é fechado, portanto, tomar o cinema como ponto de partida não foi fácil.".

Ela se refere à condução que é feita. Também há no cinema muitos elementos que são narrativos e técnicos. Isso por um lado é uma riqueza de elementos e por outro torna difícil escolher e rearranjar.

As atrizes deram uma sugestão sobre a dinâmica do experimento, por o cinema ser muito complexo: fazer a experimentação, o treinamento, de forma mais fluida e, sobretudo começar o encontro por ele. É importante ter em mente 
o que se quer, mas é preciso entrar em cena antes do estudo. Não falar antes ajuda a entender o que se quer pesquisar, pois naturalmente na condução os resultados vão apontando para o que se quer pesquisar. Que não se fala antes o que se quer pesquisar, mas que a descoberta se dê no treinamento, pois a condução direciona e as atrizes acham que poderia ser interessante que a condução revelasse o que se quer pelo apontamento, porque para o ator também é uma descoberta, já que a intersemiose acessa um repertório que inconsciente, portanto racionaliza-lo antes de vivê-lo pode engessar o corpo, logo, a ação física.

\begin{abstract}
A gente escolheu as cenas com algumas ideias na cabeça, mas não passam de ideais. Elas só vão tomar mesmo, concretamente, depois de experimentar nessa condução com o espaço, de movimentação, etc. Se a gente conversa antes e tenta entender, explica-las e argumenta-las antes, a gente tenta resolver na cabeça e não integrando com a ação e com a concretude da cena. (BRUNA)
\end{abstract}

A sugestão nos ajudou a repensar os próximos encontros, quando nos dividimos melhor a dinâmica de experimentação. Foi ressaltado que não há regras para essa dinâmica, e que seria interessante experimentar várias posições do roteiro do encontro, desde que estivéssemos atentas ao registro que isso causa e a qualidade de tradução obtida.

Pedagogicamente, quanto aos procedimentos é importante lembrar que eles estão em função dos princípios estudados, mas os exercícios são tão variáveis quanto for a criatividade do condutor. (DA SILVA, 2010)

\title{
l) PROCEDIMENTO 10: Análise de Produção/Revisão de Conceitos
}

- Tradução vs Estímulo

- Texto e Discurso

- Análise dos Roteiros de Cena

- Verticalização em artistas e discursos

Com os estudos práticos, nós percebemos que seria mais produtivo e interessante compreender os elementos expressivos de cada sistema sem buscar 
uma correspondência direta e fixa aos elementos cênicos. Dessa forma, ao pensar na perspectiva em Artes Plásticas não caberia procurar uma correspondência direta com algum elemento em Teatro, porque seria uma tarefa exaustiva e provavelmente sem resposta precisa. Nosso objetivo era, nesse sentido, entender a perspectiva em alguma pintura, por exemplo, do Van Gogh, onde pudéssemos verticalizar na função que o elemento exerce e, então, buscar uma correspondente para a função, que é uma possibilidade do uso da perspectiva em si, entre muitas outras. A verticalização nos leva necessariamente a um estudo não mais da linguagem, mas de um texto que está naquela linguagem, como a pintura do Van Gogh está em Artes Plásticas, usando códigos de significação para sua mensagem, seu discurso.

Nesse encontro problematizamos sobre os tópicos que estão listados acima. Para alguns fizemos apontamentos, quanto a outros buscamos um vocabulário comum, um consenso e outros ficaram em aberto para que a prática respondesse. $\mathrm{O}$ encontro teórico também pode ser entendido como um procedimento de pesquisa e experimentação já que ele é um levantamento da produção realizada até então e uma análise do material produzido, além de se decidir coletivamente os próximos passados que podem ser dados, também em função da encenação.

A primeira análise foi sobre a relação entre Tradução e Estímulo. Ao olhar alguns momentos do processo, inicialmente nós achamos que alguns exercícios tenderam mais para o estímulo do que para a tradução, mais ainda assim era preciso compreender melhor. Acredito que se pensarmos na tradução não como um processo mimético, mas como um processo em abertura poética, nossos exercícios foram, sim, de tradução sígnica. Recordei com as atrizes, a cena apresentada por Bruna Lima para o primeiro workshop livre de cinema, em que ela experimentou a partir do filme Brumas de Outono.

Nessa experimentação, ela usou o signo da carta, como uma forma de articular a narrativa que espacializava o tempo. Ela, no entanto, resignificou a carta com palavra escritas no corpo e traduziu a passagem de tempo, que no filme é expressa pela carta sendo jogada ao fogo da lareira, com uma ação física 
de apagar, com água, a carta do corpo. Esse exemplo mostra a tradução em nível de signo, não exatamente do sistema, para o qual ela usou outras soluções, mas ainda assim nos mostra uma abertura poética que é essencial na tradução e é a sua reescritura.

Na tradução estão presentes dois níveis: a linguagem e o texto e nos dois há signos. O signo na linguagem é lido mediante o entendimento do código, que quando é traduzido deixa no texto resultante a essencialidade da linguagem de partida. O signo no texto é como os nós de uma malha, uma rede. A tradução deles transfere e resignifica o discurso do texto de origem e deixa no texto de chegada a potencialidade de significação. Dessa forma, traduzir intersemioticamente é defrontar-se com as duas frentes e, o resultado, nos parece, é uma meta-criação. A meta-criação é tão variável como podem ser as dramaturgias do ator.

Ainda sobre tradução, quanto ao cinema problematizaram-se os níveis de linguagem e texto mediante a forma que estávamos usando, isto é, para os próximos encontros teríamos que pensar no texto fílmico como um todo e não apenas em trechos, pois assim seria como se estivesses traduzindo um quadro do filme completo, o que permitiria de partida já duas leituras: uma pelo trecho isolado e a outra pelo trecho em função do texto completo.

Nossa próxima análise sobre a significação no texto. Nós ainda não tínhamos iniciado a oficina de estudos do texto, portanto os apontamentos feitos aqui foram desenvolvidos mais adiante. Era preciso fazer uma aproximação entre texto e discurso. Nós chegamos ao exemplo do mito, como ele pode ser entendido no conceito clássico, mas também como pode ser entendido no sentido arquetípico, por sua polifonia.

Entraram em questão forma, estrutura e conteúdo, relacionados com discurso, pois a atriz Bruna Lima acredita que quando o tradutor se apropria do discurso inicial e ele altera a configuração dos signos, há também uma alteração do discurso. Ou seja, não há uma transferência direta do discurso em outros sistemas, pois o discurso é o principal material de interesse artístico do tradutor. Ela citou o exemplo da famosa pintura de Leonardo da Vinci, A santa 
ceia. Mesmo Leonardo tendo traduzido o discurso anterior registrado nos livros religiosos, ele introduziu elementos novos, como a presença de Maria Madalena ao lado de Jesus, o que alterou o discurso inicial, assim concordamos que era o mesmo texto (a santa ceia), mas a análise do discurso nos levava a outra significação. Não há uma regra sobre o discurso, pois ele altera-se ou não.

Nesse encontro ficou decidido que para ilustrar o texto e todos compreenderem a que nos referíamos, era preciso textos diferentes com o mesmo discurso, ou seja, uma pintura e um filme que tivessem uma convergência textual. Nós iríamos estudá-los.

m) PROCEDIMENTO 11: Workshop Orientado: Todas as Linguagens I

- Cada ator leva 1 pintura, 1 filme e objetos cênicos (técnicos artísticos)

- Detalhamento de signo, textos e estéticas.

Nesse encontram estavam presentes as atrizes Bruna Lima, Christiane Martins e eu. Devido ao caráter pedagógico do encontro em que nós iríamos experimentar pela primeira vez as duas linguagens juntas. irei dissertar sobre os exemplo que eu levei como sugestão de análise.

O texto em artes plásticas era Nighthawks de Edward Hopper (Figura 22) e em cinema era o dinamarquês Reconstruction (2003) de Christoffer Boe (Figura 23). Minha escolha foi orientada pelo tema comum ao grupo, o Feminino. Nos dois textos, a relação homem-mulher era central e os tratamentos dados por cada linguagem eram naturalmente distintos, porém convergiam para uma mesma atmosfera estética, de mistério e realismo.

Os mecanismos são códigos para o tradutor intersemiótico. Assim, nas artes plásticas eu comentava sobre as cores, sobre as linhas, superfícies, luz e volume como elementos expressivos que confirmavam essa leitura, apoiada também em análise críticas sobre o texto. $\mathrm{O}$ mesmo aconteceu com o filme: os enquadramentos e a dinamização que os cortes davam à narrativa aumentavam o mistério em torno do casal. Somam-se a isso, códigos próprios do filme e do conjunto de filmes que o mesmo diretor realizou que são por natureza de meta- 
narrativa, tanto que 'reconstruction', em português 'reconstrução de um amor', narra sobre a (re)construção narrativa.

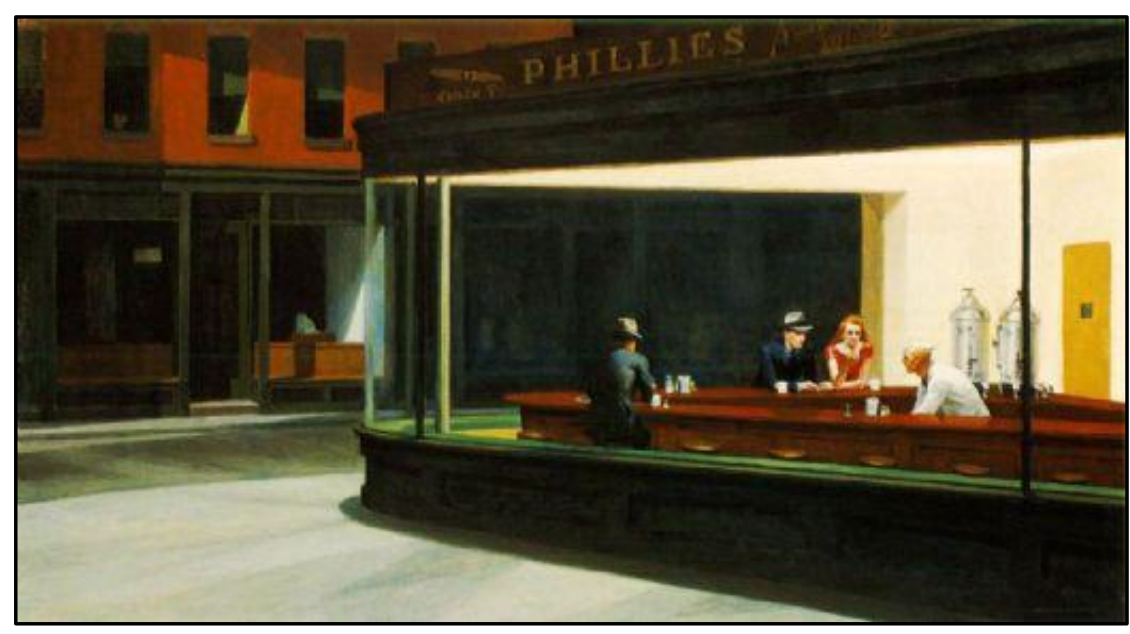

Figura 22: Nightwalks - EDWARD HOPPER (Fonte: Arquivo Pessoal)

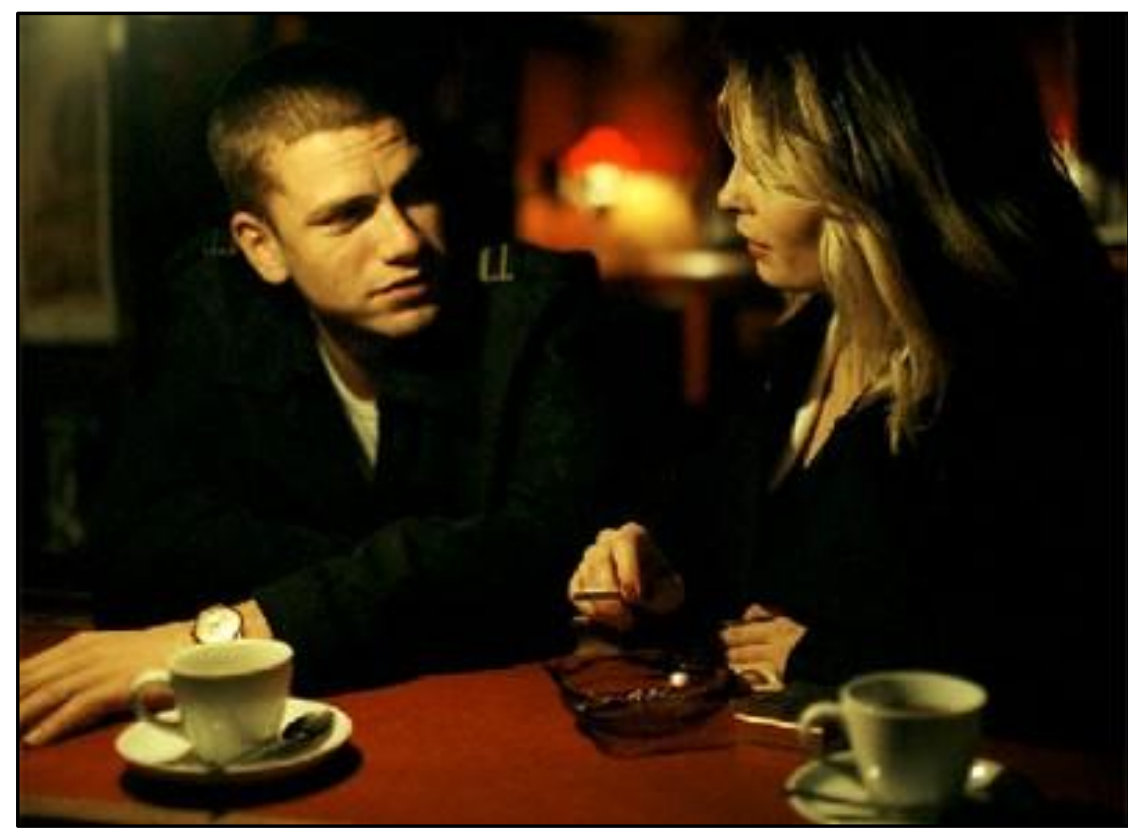

Figura 23: Reconstrução de um Amor - CHRISTOFFE BOE (Fonte: Arquivo Pessoal)

Conclui que a reconstrutividade que havia no filme, juntamente à leitura de perspectiva aliada a narrativa de múltiplos olhares que eu identificara em Hopper, eram um diálogo interessante para a tradução, já que o embate com a linguagem feita nos dois primeiros casos poderia ser interessante de transferir para o Teatro. Eu identifiquei a possibilidade de assumir a ficcionalidade do ponto de vista feminino e investigar uma ação física que traduzisse os closes, as mudanças de tempo físico e dramático no filme e que reproduzisse plasticamente em cena, com luz, cenário e figurino o mesmo universo imagético 
que estava presente nos dois textos. É possível, no entanto, que nesse processo de criação da dramaturgia do ator surgisse um tratamento com a palavra pois o noir nas duas linguagens, sugeriam não apenas o gesto, mas a palavra (palavra como gesto). Mais para isso era preciso estudar verticalmente as formas como que o signo opera no texto escolhido.

\subsubsection{TEXTO}

Neste subcapítulo discorro inicialmente sobre as principais teorias que abordam o texto fora dos sistemas verbais, para assim pensarmos em pinturas e filmes como textos também. Foco, sobretudo no pensamento de Roland Barthes sobre a diferença entre obra e texto o que me leva a conduzir os estudos do texto em busca da sua essencialidade de discurso.

Ao descrever a segunda oficina ministrada - Oficina de Estudos do Texto - , buscamos a compreensão da malha de signos que eles formam. Nesta etapa, o foco está sobre os textos escolhidos pela atriz Christiane Martins, em especial o estudo dos textos do pintor Henri de Toulouse-Lautrec e do cineasta Jean-Luc Godard. Ainda na oficina, descrevo os procedimento e exercícios que foram aplicados e analiso os resultados obtidos.

\section{AÇÃO 1: CONTEXTUALIZAR OS TEXTOS NA PESQUISA}

O conceito de textura ${ }^{11}$ foi introduzido por Halliday e Hasan, ao descrever como o texto forma um unified whole ${ }^{12}$, assim tal como eles o definiram: "the word TEXT is used in linguistics to refer to any passage, spoken or written, of whatever length, that does form a unified whole'13. (HALLIDAY \& HAASAN, 2000).

\footnotetext{
${ }^{11}$ Do inglês, texture.

12 Tradução minha: um tudo unificado.

13 Tradução minha: "a palavra TEXTO é usada em linguística para se referir a qualquer passagem, falada ou escrita, de qualquer que seja a extensão, que forma um todo unificado".
} 
Nesse sentido, textura seria: "the property that distinguishes text from non-text. Texture is what holds the clauses of a text together to give them unity"14. Textura, o autor sugere, envolve a interação de dois componentes: coerência - a relação do texto com seu contexto extra-textual - e coesão - a forma como os elementos dentro do texto agrupam-se como um 'unified whole'. É importante mencionar que Halliday e Hansan referem-se a texto somente como nas linguagens escritas e faladas.

Entretanto, a perspectiva de um texto artístico abre a possibilidade de ir além da coerência e coesão como principais elementos de textualidade, e ainda assim, poderíamos nos referi à sua textura. Muito embora esses termos estejam sendo usados hoje em dia em contextos diferentes aos que os funcionalistas os aplicaram. Essa abertura natural aconteceu devido ao advento de escritos filosóficos a cerca do assunto.

Roland Barthes em $O$ rumor da lingua ${ }^{15}$ escreveu muitos ensaios sobre literatura no geral. Em um específico, Da obra ao texto ${ }^{16}$, ele deu uma definição chave ao opor obra a texto, considerando a produção artística. Esta é também uma chave para entender porque esse termo está tão em voga ultimamente.

Nessa citação, Barthes explica a importância de distinguir os dois termos:

Distinguishing them is not a matter of establishing a crude list in the name of modernity and declaring certain literary productions to be 'in' or 'out' in the basis of their chronological situation. [...] the difference is as follow: the work is concrete $[. .$.$] the Text, on the other hand, is a methodological field. (BARTHES,$ p. 59)

Como um campo metodológico, o dinamismo do texto é apresentado como um processo produtivo. Por causa disso, a função do texto é uma força paradoxal e subversiva. Ela resiste a classificações de acordo com categorias e hierarquias tradicionais. Ao fazê-lo, ele alarga os limites de legibilidade e racionalidade. Pela oposição, Barthes então estabelece uma relação metafórica com a distinção proposta por Lacan de 'realidade' e 'real', onde ele entende o

\footnotetext{
${ }^{14}$ Tradução minha: "a propriedade que distingue o texto do não-texto. Textura é o que mantém as orações de um texto juntas para lhes dar unidade."

${ }^{15}$ The Rustle of Language (Traduzido por Richard Howard, 1986)

${ }^{16}$ From Work to Text, p. 56.
} 
primeiro como exibido e o segundo como demonstrado. Como um exemplo, Barthes cita que as obras podem ser vistas em livrarias, catálogos e em listas de cursos, enquanto que o texto 'revela-se, articula-se de acordo ou contra certas regras'.

Essas regras mencionadas por Barthes podem ser entendidas como as regras que dizem o que o texto deve ser - como podemos ver com as teorias funcionais do texto - e que também podem ser sobre uma estrutura interna que conduz e gera o texto em si. Em outras palavras, Barthes diz: "while the work is held in hand the text is held in language: it exists only as a discourse." 17

A combinação de ambas as teorias funcionais e filosóficas de texto funcionam como um guia no método da tradução, já que nós apresentamos a tradução como um fenômeno da comunicação, mas também com perspectivas filosóficas.

\subsubsection{As pinturas de Toulouse-Lautrec}

A escolha pelas pinturas de Toulouse-Lautrec tiveram início quando, ainda na ocasião da Oficina de Estudos da Linguagem, a atriz Christiane Martins nos apresentou à tela A Roda (Figura 18) deste autor. Quando, por compromissos com a Escola de Arte Dramática e incompatibilidade de agenda, as atrizes Bruna Lima e Áurea Teixeira Barros tiverem que se afastar da pesquisa prática, nós resolvemos que as investigações seguiriam centradas apenas no trabalho que Christiane vinha desenvolvendo. Assim, dei início à Oficina de Estudos do Texto para então analisar quais escolhas a atriz trazia e quais qualidades apareciam em seu trabalho cênico, por decorrência das mesmas.

Como também ficamos sem encenador, já que Fabiano Benigno também precisou afastar-se por alguns meses por motivo de trabalho, tive que elaborar procedimentos para nós nos aproximarmos mais da pintura, compreender sua textura e dar meios para que a atriz construísse sua própria tecedura cênica. A

17 Tradução minha: "enquanto a obra está contida nas mãos, o texto está contido na linguagem: existe somente como um discurso". 
ordem desses procedimentos tem a ver com o tipo de pesquisa que eu havia feito até então e com as necessidades que a atriz apresentava.

\section{a) PROCEDIMENTO 1: Análise da pintura "A Roda"}

- Movimento Visual

- Orientação e Direção Espacial

- Densidade (Centro Geométrico e Centro de Percepção)

- Elementos Expressivos (linha, superfície, volume, luz e cor).

Começamos por uma distinção básica de que a tela $A$ Roda é um exemplo de pintura figurativa. Desse modo, identificamos a figura de uma bailarina, que poderíamos dizer ser uma dançarina de cabaré devido sua caracterização e vestimentas. Identificamos também os outros elementos do espaço: um palco, uma casa noturna, iluminação elétrica, e outras figuras que chamaremos de plateia.

Por ocupar maior parte do centro geométrico e quase todo centro de percepção, a figura da bailarina é destaque na composição do quadro. Quando pensamos na densidade desse quadro, fomos novamente levadas ao que Appia disse sobre a relação do corpo com o espaço. ${ }^{18}$ A oposição da figura da dançarina - corpo vivo - ao espaço é o que dá movimento à cena. Passamos assim, a pesquisar as relações de movimento que o quadro apresentava, pois assim chegaríamos à mobilidade que é o essencial na tradução intersemiótica entre Artes Plásticas e Artes Cênicas.

Quanto à orientação e direção espacial, notamos a predominância das linhas diagonais, em espiral e curvas o que, segundo Fayga Ostrower, denotam instabilidade ao movimento. De toda forma, por mais que as linhas denotem instabilidade, a expressão facial da bailarina, aparentemente de olhos fechados,

\footnotetext{
18 "Para receber do corpo vivo a sua parte de vida, o espaço deve opor-se a esse corpo; adquirindo as nossas formas, aumenta ainda a sua própria inércia. Por outro lado, é a oposição do corpo que anima as formas do espaço. $\mathrm{O}$ espaço vivo é a vitória das formas do espaço. $\mathrm{O}$ espaço vivo é a vitória das formas corporais sobre as formas inanimadas. A reciprocidade é perfeita." (APPIA, 1921, p. 29)
} 
e a leveza do contorno que mesmo os traços mais rígidos do seu braço mostram, dão equilíbrio à figura.

Prestemos maior atenção às linhas. A ausência de intervalados entre elas, chamadas pela autora de falhas, aumentam a velocidade do Movimento Visual. A direção das linhas apresenta diferentes grupos de linhas na mesma direção e em uma relação harmônica, pois formam vetores na circunferência. Percebe-se também que há linhas verticais no eixo da dançarina o que acentuam sua estabilidade, logo seu equilíbrio, em oposição ao movimento centrífugo do restante das linhas da grande roda formada pela saia.

Nesta tela, o efeito de bidimensionalidade da superfície é atenuado pelo desenho das cochias no palco, o que faz percebemos maior profundidade no espaço que a bailarina ocupa. Dessa forma, mantém-se o grande movimento espacional que cerca a figura de destaque. O mesmo já não ocorre com o espaço ocupado pela plateia. Vemos formas chapadas, com contornos indefinidos e que se misturam em cores com o fundo da casa noturna - onde com traços simples vemos que há mais plateia. É como se Toulouse tirasse a atenção e o movimento desta parte.

Os elementos de volume, luz e cor ultrapassam a estrutura bidimensional e por isso são considerados mais dinâmicos. $\mathrm{O}$ aspecto essencial do volume é o destaque que está para o palco e novamente para as cochias.

A relação de claros e escuros da luz se torna expressiva no quadro pela alta iluminação que há na saia da dançarina em oposição a ela e mais fortemente em oposição ao espaço, ainda que o espaço esteja figurativamente iluminado por energia elétrica e a luz que está no palco estenda-se também pelo chão. Vimos ao estudar luz que este pode ser um jogo estabelecido também na reprodução do fenômeno da luz, embora ele não seja o suficiente.

Sobre as cores, podemos notar o uso do verde e do azul como recorrentes na representação noturna de Toulouse-Lautrec. Os tons em pastel são resquícios de sua fase impressionista. Essas cores foram signos fortes para a atriz Christiane Martins que nessa época iniciou uma pesquisa a cerca do filme Maria 
Antonieta de Sophia Coppola, pois acreditava haver semelhança entre o clima expressional de ambos.

b) PROCEDIMENTO 2: Formas de leitura

- Análise do quadro de leitura de Fayga Ostrower

Após a análise do quadro, notamos que ainda permanecíamos em dúvida quanto à identificação do discurso que esses elementos expressivos apresentavam. Assim, trouxe para a atriz um esquema de leitura proposto pela autora de Universos da Arte, para ter uma sequência da ordem de importância na composição do quadro, ou seja, o que deveríamos olhar e quando.

(Figura 24)

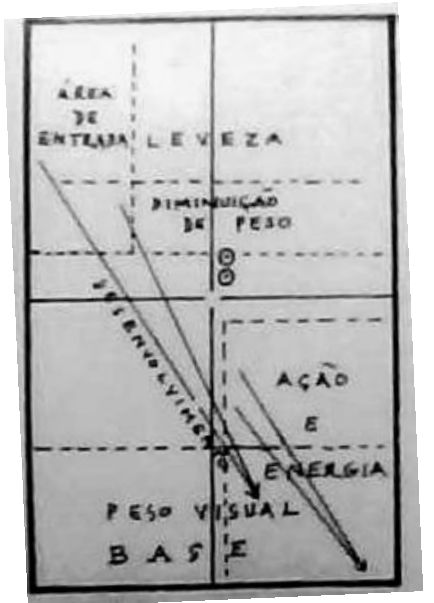

Figura 24: Quadro de leitura - FAYGA OSTROWER (Fonte: Universos da Arte, p. 54)

\section{c) PROCEDIMENTO 3: La Löie Fuller}

- Vida e Obra

A atriz Christiane nos alertou que sua escolha havia sido essa em função da figura da bailarina e que gostaria de centrar sua leitura na composição desta imagem, já que a imagem da dança suscitava nela uma imaginação sobre quem seria aquela mulher fora dos palcos, como ela agiria fora de lá. Gostaria também de que procurássemos um texto de teatro, pois isso lhe daria maior segurança na cena. 
Relembrei de que procurar um texto dramatúrgico, como ela nos pedia, não seria o mais aconselhável nem talvez necessário nesse momento, pois eu queria investigar a dramaturgia que nasce da ação física, do corpo em cena, ou mesmo da própria ficção da atriz. Christiane continuou a detalhar ações que imaginava que e aquela figura fazia e, assim, apontei que tais ações já geravam leitura dramatúrgica.

Assim, realizei uma pesquisa para conhecermos mais sobre a artista Löie Fuller (Figura 24), já que Toulouse-Lautrec pintava as dançarinas que ele mesmo via na noite parisiense. Notemos que o nome completo do quadro é $A$ bailarina Loie Fuller vista dos bastidores - A Roda.
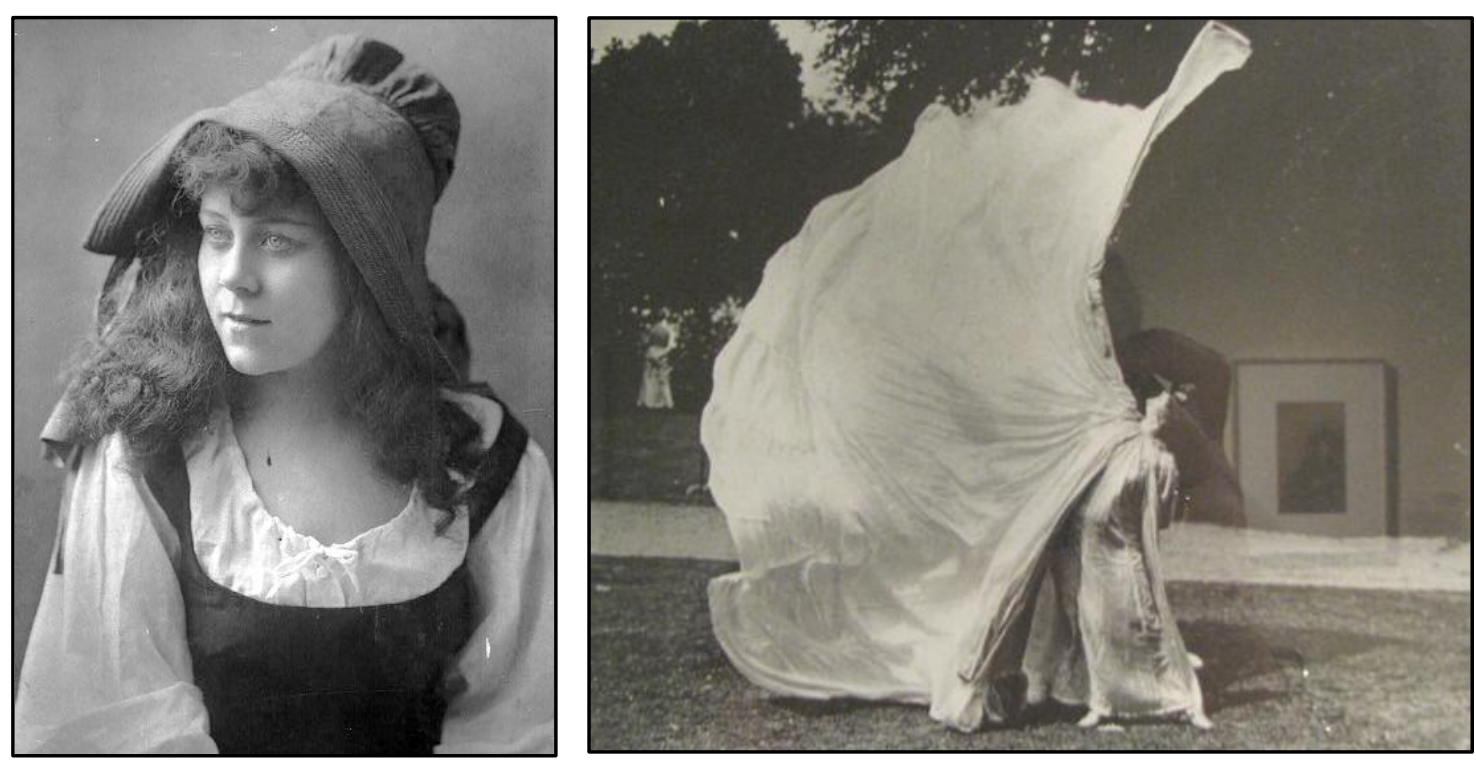

Figura 25: Löie Fuller, vestida para o personagem de uma peça - ELLIOT \& FRY e, à direita, com seu estilo e assinatura inconfudíveis de dança: ampla pesquisa com tecidos (Fonte: Maryhill Museum)

Comecei por constatar que se tratava mesmo de uma personagem real, como tantas as outras que Toulouse havia pintado, tais como Jane Avril, Yvette Guilbert, May Milton, a lady clown Cha-U-Kau, La Goulue, May Belfort, Aristide Bruant, Valentin le désossé, entre muitos outros. ${ }^{19}$

A informação que mais nos chamou atenção era a autonomia e inventividade de Löie Fuller como artista, sendo ela uma pioneira na dança moderna e na iluminação teatral. Além das coreografias pelas quais ela era responsável, Löie criou o que ficou conhecido como Dança Serpentina, uma espécie de coreografia onde Fuller fazia uma união de seus trajes

\footnotetext{
${ }^{19}$ Ver demais artistas retratados por Toulouse-Lautrec em Anexos.
} 
confeccionados em seda com luzes multicoloridas. Isto ocorreu após ela perceber o efeito de refletores em seus trajes, assim, resolveu explorar por toda a sua vida essa ideia de iluminação.

Nesse encontro, foram exibidos vídeos de performances de Löie, lemos o trecho "From Louise to Loie" de sua biografia intitulada Loie Fuller Goddess of Light e outros registros, tais como fotografias raras e cartazes de show. Outros detalhes sobre essa pesquisa estão nos Anexos.

\section{d) PROCEDIMENTO 4: Pesquisar o Movimento}

- Reconhecer as relações de movimento na tela

- Exercício de Movimento Visual 1 (a duplicação)

- Exercício de Movimento Visual 2 (instabilidade e estabilidade)

- Exercício de Movimento Visual 3 (investigação temática)

Iniciamos o encontro retomando a discussão sobre velocidade, equilíbrio e demais relações de movimentos que havíamos identificado no quadro A Roda. Em seguida, apliquei uma série de exercícios a partir de adaptações do que Fayga Ostrower propõe em seu livro.

Mais tarde, voltei a repetir esse exercício com os membros do CEPECA, ao final, descrevo qual orientação eles me deram. Irei inicialmente mostrar as instruções do exercício, depois comentar a análise feita na hora e algumas dúvidas que surgiram.

\section{- Exercício 1: A duplicação - pode ser feito com dois atores}

- Ator 1: Faz um gesto (Orientador traça uma linha)

- Ator 2: Repete o gesto do Ator 1 (Orientador traça uma linha igual)

- Orientador pergunta: "Os gestos/linhas ficaram iguais?".

O orientador deve explicar sobre 'alteração' e 'apropriação'.

- Ator 1: Refaz o próprio gesto (Orientador retraça a linha 1)

- Aplicação: Jogos (Espelho - Viola Spolin)

- Apropriação de Workshop 
A avaliação retoma a explicação de Ostrower sobre forma sendo igual a conteúdo:

Ao retraçar uma linha (gesto / palavra) ela é sempre modificada. A modificação pode ser ligeira, mas não deixa de ocorrer. Duplicada a linha (o gesto / a palavra) se torna um pouco mais espessa, um pouco mais grossa; se havia alguma indicação anterior de curva, reta, ou angularidade, linha (gesto / palavra) seria agora mais curva, mais reta, mais angular e também menos hesitante, menos nervosa, menos fluida, menos espontânea. [...] Aparecem ênfases que antes não existiam. (OSTROWER, p. 39)

\section{- Exercício 2: Estabilidade e Instabilidade}

- Utilizando uma sequência de linhas, o ator deve também estabelecer uma sequência de gestos.

- Ele deve relatar quais momentos sua ação trouxe estabilidade e em quais trouxe instabilidade em seu corpo.

As imagens podem ser vistas nas Figuras 26 e 27.

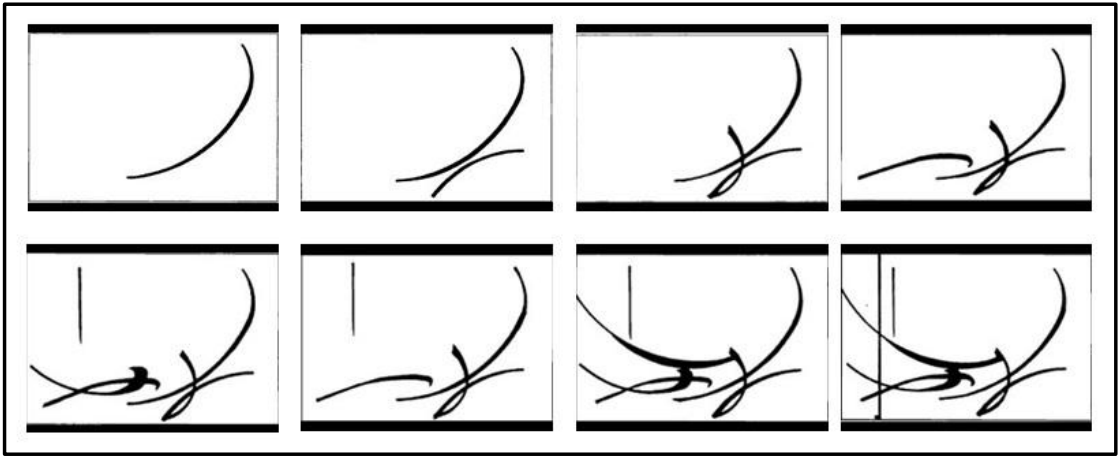

Figura 26: Sequência de Linhas I - FAYGA OSTROWER (Fonte: Universos da Arte, p. 42)

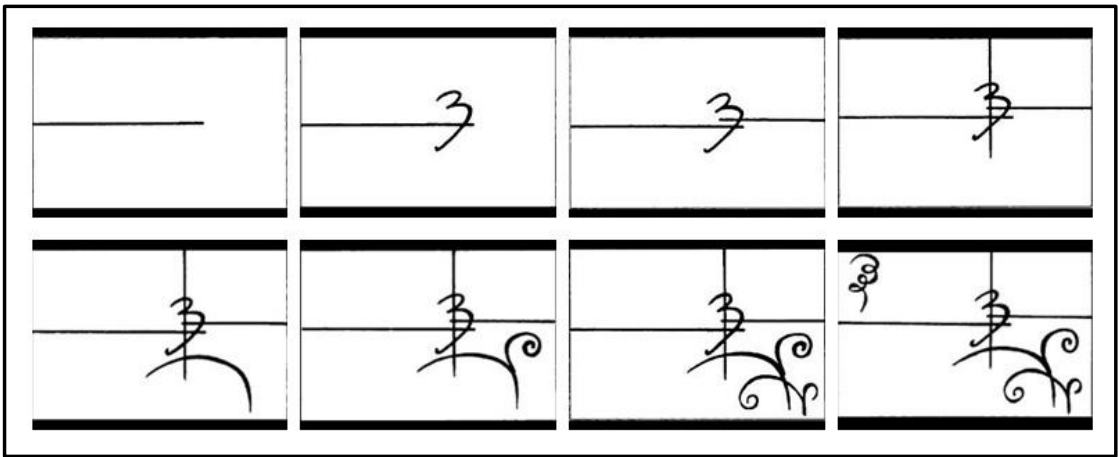

Figura 27: Sequência de Linhas II - FAYGA OSTROWER (Fonte: Universos da Arte, p. 44)

Como sequência, pode-se tentar um exercício de investigação temática.

Nesta etapa, podem-se acrescentar informações do contexto temático e forma da 
pintura para se estabelecer maiores proximidades formais e também de tema, em cena.

Voltei a apresentar esse exercício no encontro semanal do CEPECA. Participaram do exercício a doutoranda Evinha Sampaio e o Profo ${ }^{\circ}$ Dr ${ }^{\circ}$. Eduardo Coutinho. Nessa ocasião, apliquei também um exercício bastante detalhado para compreender a relação entre linha (espaço/tempo) e para aplicá-los utilizei as imagens Mulher adormecida, de Rembrandt e Ator no palco, de Honoré Daumier ${ }^{20}$.

Embora a recepção para com os exercícios tivesse sido boa, a orientação mais recorrente era de que este era um caminho detalhado por demais. Estabelecer essa relação mínima entre os elementos expressivos das artes plásticas - e suas variações - com os movimentos do corpo do ator implicaria em também ter que descrever minimamente essas relações. Na ocasião, teóricos como Laban foram citados, porém ficou decidido por consenso que as melhores qualidades desse processo de tradução não viriam pela investigação minimalista do movimento, e sim da elaboração consciente da dramaturgia do ator - sobretudo, se pensarmos na pesquisa como nível de mestrado.

\section{e) PROCEDIMENTO 6: Pesquisar análise estética e de discurso de A Roda}

- Pesquisar em diferentes autores e compartilhar

Tendo seguido as orientações recebidas, voltei a propor à atriz Christiane Martins que tentássemos nos envolver mais esteticamente com a obra. Assim que identificássemos seu discurso, estaríamos prontas para iniciar processos de improvisação cênica. Compartilharei, aqui, a leitura que eu mesma encontrei, já que teve uma boa recepção.

\footnotetext{
Ele trata de um tema - a realização de danças exibicionistas provocativamente no palco do café-concerto - que escritores contemporâneos moralistas lamentavam, mas, a ficção de Lautrec coloca o espectador na coxia como se vendo a performance do companheiro, à espera de uma deixa. Assim, o motivo nem superficialmente nos apresenta o espetáculo, exibido para o olhar
}

\footnotetext{
20 Ver imagens em Anexos.
} 
voyeurista masculino - como criado em uma ilustração contemporânea por Steinlen - nem a caricatura do público; o ponto de vista de Lautrec conspira para ser ao mesmo tempo discreto e acrítico. (p. 20)

Lendo isso foi praticamente impossível não recorrermos de imediato à própria história de Tolouse-Lautrec para explicar o porquê da visão discreta e acrítica que essa imagem nos mostrava.

Como é de fácil conhecimento, Henri de Toulouse-Lautrec foi um pintor francês que teve sua fase mais marcante na virada do século XIX para o XX. Sua origem era nobre, tendo sido filho de um casamento entre primos, como era comum na aristocracia. Nasceu com saúde frágil e depois de uma série de acidentes e quedas, desenvolveu uma atrofia nos membros inferiores o que o impediu de crescer normalmente. Assim, Henri era um adulto com corpo de criança. Uma figura que destoava do meio ao qual fazia parte.

Na vida adulta, Toulouse muda-se para Montmartre, reduto de artistas, boêmios e da maioria dos pintores de sua geração. Lá, entra em contato com os cabarés, os dancing-halls, as maison closes e as vanguardas estéticas. Integra-se de tal ponto ao ambiente que não é surpreendente que em $A$ Roda sua visão seja discreta e acrítica, mesmo porque, mais tarde viemos a conhecer o contexto em que a pintura havia sido feita: um estudo sobre os movimentos de Loie Fuller.

\section{f) PROCEDIMENTO 7: Toulouse-Lautrec - vida e obra}

- Pesquisar e compartilhar características que mais chamam a atenção.

- Relacionar características de estilo e estética ao discurso que se apresenta.

Há um grande interesse em torno da movimentada vida de ToulouseLautrec, mas em nossas pesquisas, logo chegamos a dois livros que apresentam uma leitura mais aprofundada do artista e propõe um repensar sobre o pintor ${ }^{21}$.

Lautrec, of course, had other contemporary reputations. These might also deal with his subjects, but not from the judgmental, pseudo-biographical angle. Rather, they chose to elide what Lautrec represented with how he represented it. "There is a brash humour and a cruelty in Lautrec's work when he is

\footnotetext{
${ }^{21}$ Ver imagens do artista em Anexos.
} 
depicting dance-halls, brothel interiors and unnatural liaisons", reckoned Geffroy in 'La justice' in 1893; 'But he retains his integrity as an artist: his pitiless powers of observation preserve life's beauty, and the philosophy of vice which he parades with a sometimes provocative ostentation nevertheless takes the force of a lesson in clinical morality through the strength of his drawings and the seriousness of his diagnosis 22 (p. 13)

Toulouse não é nem gratuitamente acrítico ou impiedoso. Notamos que há em sua obra uma precisão. Segundo Geffroy:

Lautrec 'brings to his art new methods of interpretation; [...] contour is the only means of fixing his thoughts... in his drawing there is nothing that is useless or ill-considered, and everything indispensable is there; people are always shown in appropriate settings; the disappointments that overwhelm them, the poverty that tortures them, the desires that convulse them: all can be read here, indelibly engraved. To such commentators it was the incisiveness and wit of Lautrec's powers of observation, combined with the economy with which they were conveyed, which marked Lautrec's work; his choice of subject-matter was not personal exposé but a frank account of a stratum of Parisian society. ${ }^{23}$

Assim, passamos a levantar as principais questões a cerca de Lautrec:

Como sua escolha de objeto foi determinada? Os seus meios de representação mídia, composição, toque, cor - sugerem algum objetivo artístico? E os objetos e meios aliados tendem a implicar ou suscitar certas leituras de suas imagens? $\mathrm{Ou}$ seja, o objetivo da Oficina delineava-se cada vez mais: estávamos procurando seu discurso.

22 Tradução minha: Lautrec, com certeza, tinha outras reputações contemporâneas. Estas podem também ter a ver com seus temas, mas não a partir do ângulo julgamentoso, pseudo-biográfico. Ao invés disso, optaram por elidir o que Lautrec representou com a forma como ele representava. "Há um humor ousado e uma crueldade no trabalho de Lautrec, quando ele está representando os dance-halls, os interiores de bordéis e as relações não-naturais", conta Geffroy em 'La justice' em 1893; "Mas ele mantém a sua integridade como artista: seus poderes impiedosos de observação preservam a beleza da vida, e a filosofia do vício que ele desfila com uma ostentação, às vezes provocativa, no entanto, leva a força de uma lição de moralidade clínica através da força de seus desenhos e da seriedade de seu diagnóstico.

${ }^{23}$ Lautrec "traz para sua arte novos métodos de interpretação; [...] o contorno é o único meio de fixar os seus pensamentos ... em seu desenho, não há nada que seja inútil ou mal considerado, e tudo de indispensável está lá, as pessoas são sempre apresentadas em contextos adequados, as desilusões que as sobrecarregam, a pobreza que as torturam, os desejos que os abalam: tudo pode ser lido aqui, indelevelmente gravado. Para tais comentadores foi a incisividade e a sagacidade dos poderes de observação de Lautrec, combinada com a economia com os quais foram emoldurados, que marcou o trabalho de Lautrec; sua escolha de objeto não foi a exposição pessoal mas um franco relato de um extrato da sociedade parisiense." (p.14) 
g) PROCEDIMENTO 8: Ações

- Estabelecer uma estrutura ficcional

- Seleção de pinturas de Toulouse-Lautrec

- Escolha de objetos de cena

- Músicas como estímulo

- Experimentando ações

- Atriz reorganiza seleção

- Experimentando ações

- Criação de partitura e Repetição

- Debate sobre discurso

Selecionei diversas imagens, quadros de Toulouse-Lautrec, seguindo uma estrutura ficcional que a atriz havia comentado durante a passagem da primeira para a segunda Oficina Pedagógica. Nessa ocasião, ela apresentou a ideia de mostrar a trajetória do Feminino em torno de um Baile. Estruturalmente, organizei telas que dialogavam com os momentos de antes do baile, no baile e depois do baile, que ela havia mencionado. As imagens ficaram reorganizadas pela atriz, como se pode ver nos Anexos.

\subsubsection{Filmes de Jean-Luc Godard}

Apresentei à Christiane, no nosso primeiro encontro sobre textos, um trecho do filme Uma Mulher é Uma Mulher24, de Jean-Luc Godard, onde a atriz Anna Karina interpreta uma cena musical, cantando Chanson d'Angela. Após aprovar a escolha, a atriz comentou:

Acho que teve uma coisa inconsciente [...] que me levou para o Toulouse, que me levou para o (filme) Maria Antonieta. [...] Estou começando a deixar consciente essas coisas que antes estavam inconscientes, e agora vendo esse clip fica óbvio que tudo o que eu peguei estava ligado à cultura francesa... que eu estou com um encantamento com isso. (CHRISTIANE) ${ }^{25}$

\footnotetext{
${ }^{24}$ Ver trecho do filme, no DVD Anexos.

${ }^{25}$ Em 14 de abril de 2011.
} 
A atriz também comenta que a personagem de Anna Karina lembra um pouco a passagem da euforia para o trágico que ela havia identificado também na dançarina de Toulouse-Lautrec.

\section{a) PROCEDIMENTO 1: Repetição}

- Escolho um trecho do filme para a atriz

- Atriz escolhe uma música, como estímulo.

- Repetição da partitura anterior pela atriz

- Inserção de imagens do filme, em cena.

- Experimentar por improvisação a tradução do trecho do filme para a cena.

Esse foi o primeiro procedimento para investigar o discurso que os filmes de Godard traziam. Nessa etapa, estudávamos, sobretudo, Uma Mulher é Uma Mulher, filme de 1959.

A escolha da atriz foi a música $V C R$, da banda The $x x$. Nós organizamos o espaço, ensaiando no teatro Sala Alfredo Mesquita na ECA. Neste encontro, nós já estávamos começando a pesquisar sobre os filmes de Godard - o que viemos a fazer verticalmente logo em seguida.

\section{b) PROCEDIMENTO 2: Estudo/Análise do Discurso}

- Estudo e análise de 'Uma mulher é Uma mulher'

Iniciei uma pesquisa teórica, histórica e estética dos filmes de Godard. Fiz um recorte sobre Uma mulher é Uma mulher, devido à temática que a atriz Christiane estava pesquisando, $\mathrm{O}$ Feminino. Como também pesquisávamos Toulouse, sobretudo um quadro em que ele retratava uma dançarina, uma artista, julguei que essa tinha sido a melhor escolha. $O$ filme tem como protagonista a atriz Anna Karina, a então esposa do cineasta Godard.

Essas foram algumas das análises que se aproximaram de nossa leitura: 
In comparison with the visual complexity of 'À bout de souffle', this film realizes all the possibilities of color composition instantaneously, which gives a great sense of easiness. It's 'La Nouvelle Vague en couleurs', where unmarried Madame Récamier (Anna Karina) celebrates Alice's unbirthday at the stripbistro with the Cocteau loudspeakers announcing the numbers, among which is her simple proclamation, "Je suis très belle." La Parisienne mise à nu pour ses célibataires. Une femme est une femme is unutterably beautiful because Paris is. Godard is in constant modulation. A bit of flyting in a standard mocking tone becomes abstract: "Wandering Jew!" "Fascist!" "Pervert!" Madame la Parisienne has a little gizmo that tells her when the time is ripe. She sits in a chair against the wall and reads the instructions, holding the gizmo in one hand and manipulating it with the other. Godard holds the medium close-up entrancingly, then slowly dollies out to Legrand's music. They listen to a game on the radio, the announcer waxes poetic, "It's pure Shakespeare!" Émile Récamier (Jean-Claude Brialy) is saving himself for the Sunday bicycle race like a champion. Titles appear on the screen announcing the writer's viewpoint, or the critic's. There's another figure in this witty ménage, is it Osborne? No, it's Lubitsch (Jean-Paul Belmondo), who is just a little bit Wimpy. Franscope gives a wider view, but if you ask it's just the color, the way you know when an egg is done. Lubitsch is at the bar, asking Jeanne Moreau about the film for Truffaut (it is 1961, according to a wall calendar). "Moderato." Now shots of the crowd, rapidly assembled in a sequence which asks the question, are you looking for your dead, or France, or the day of the week? And here is the letter joke that became Montparnasse-Levallois, and comes from Cause for Alarm!, which takes the mickey out of The Postman Always Rings Twice. Aznavour gets down to cases. "You've let yourself go." Madame has done Lubitsch, now Émile has life imitating art. "I don't know," he says, "if this is a comedy, a tragedy, or a masterpiece." It's pure Shakespeare, the schema of Othello or Cymbeline analyzed to nothingness and built up day by day on the streets and in the rooms of Paris, just the way a painter resumes the activity of the preceding day, just the way the bard inscribed his lines. (MULROONEY, 2012)26

Em Um filme é um filme, José Lino Grünewald diz: “Um filme é um filme Uma mulher é uma mulher. O cinema é cinema e Godard é essencialmente cinema". (GRÜNEWALD, p. 90) Isso porque Godard sempre fez cinema pensando e refletindo o cinema. Em Uma mulher..., o autor junta-se, novamente ao músico Michael Legrand e cria - neste filme que é uma homenagem aos musicais americanos - o antifundo musical clássico:

“[...] é a justaposição de dois opostos ou heterogêneos em nossa tradicional concepção de afinidades entre o melódico e o figurativo. Para uma sequência agitada, uma música suave, terna; para uma cena trivial, cotidiana, acordes solenes ou compassos heróicos" (GRÜNEWALD, p. 93)

Notamos que isso não está só na concepção musical. Trata-se de um duplo, uma ambiguidade que perpassa todo o filme. Ele nos apresenta Ângela

${ }^{26}$ MULROONEY, Christopher in http://cmulrooney.tripod.com/godard.html 
como uma garota independente, que trabalha em um strip-bristó, irônica, que trata o namorado com perspicácia, para logo em seguida, nos mostrar seu lado mais vulnerável, quando ela insiste com o namorado em ter um filho. De certa forma, pareceu-nos estranho ver um filme que retratava os efervescentes anos 60, momento de revoluções e liberações, apresentar um conflito que julgávamos inapropriado para a personagem de Ângela.

Em seguida, passamos a aprofundar o discurso, percebendo a própria ironia e ambiguidade que residia no título. Assim, Christiane foi acrescentando mais informações à sua criação do Feminino, porém agora com influências do estilo de Godard.

In Une Femme est Une Femme: Two Blue eyes: Giraudoux. A red Umbrella: Aragon. That is Angela. Ana's song "Everyone wonders why". From Griffith to Bresson, the history of the cinema and the history of its errors are one: the error of trying to paint ideas better than music, to illustrate actions better than the novel, to describe feelings better than painting. Why does cinema begin? No doubt like the other arts, when form becomes style. But let us be clear about style, for style is a matter of meaning. It's... I don't know. For instance, it's the perspective of Mizoguchi, the aggression of Orson Welles. Style... how can I express it? It is the reality which the mind claims for itself. I think, too, it is also the definition of liberty given by Hegel. One day, in defense of Chaplin's A King in New York, Rossellini said: "This is the film of a free man". Basically, that's it. To create cinema, all one has to do is film free people. Like Emile and Angela. (GODARD, p 68) $)^{27}$

Mais ainda assim, tanto Godard quanto Toulouse-Lautrec tinham uma vasta obra e muitos aspectos de representação da sociedade parisiense, que era o que mais atraia Christiane Martins para essa escolha. Então, decidimos que para a próxima etapa nós investigaríamos os signos estéticos que nos interessavam e assim chegaríamos à essencialidade do discurso a traduzir.

27 Tradução minha: “Em Une Femme est Une Femme: Dois olhos azuis: Giraudoux. Um guardachuva vermelho: Aragon. Essa é Angela. Canção de Ana: "Todo mundo se pergunta por que". De Griffith a Bresson, a história do cinema e da história de seus erros são uma: o erro de tentar pintar ideias melhores do que a música, de ilustrar ações melhores do que o romance, de descrever sentimentos melhor do que a pintura. Por que o cinema começa? Sem dúvida, como as outras artes, quando a forma torna-se estilo. Mas sejamos claros sobre o estilo, estilo é uma questão de significado. É ... Eu não sei. Por exemplo, é a perspectiva de Mizoguchi, a agressão de Orson Welles. Estilo ... como posso expressá-lo? É a realidade que a mente reivindica para si. Acho, também, é igualmente a definição de liberdade dada por Hegel. Um dia, em defesa de Um Rei em Nova York de Chaplin, Rossellini disse: "Este é o filme de um homem livre". Basicamente, é isso. Para criar cinema, tudo o que se tem que fazer é filmar pessoas livre. Como Émile e Angela." 
Como estávamos próximo ao período de férias letivas, suspendemos os encontros por alguns dias.

\subsubsection{SIGNO}

Um pouco antes do período de férias, convidei para participar da pesquisa a atriz Patusca, que eu já conhecia e sabia ter uma afinidade com as Artes Plásticas. Logo no início da pesquisa, ela demonstrou ter grande interesse e afinidade com as pinturas de Toulouse-Lautrec.

Iniciei com ela a terceira etapa, Oficina de Estudo dos Signos, propondo a repetição do procedimento 8 , da oficina anterior, chamado ações, pois tinha interesse agora de experimentar a tradução pelo processo de apropriação dos resultados já obtidos.

Em um terceiro momento, na volta das férias, passamos a ter os encontros com as duas atrizes, pesquisando e escolhendo. A seguir, mostro um resumo de nossas atividades, os procedimentos adotados e dos signos que foram escolhidos para a etapa de Encenação.

a) PROCEDIMENTO 1: Reaplicação do procedimento 'Ações'

- Atriz Patusca

- Reaplicar o procedimento com as imagens já na ordem final.

- Identificar semelhanças e diferenças

- Debate com a atriz sobre as escolhas feitas

Foi importante deixar bem claro que a atriz estava livre para contribuir com sua própria leitura, por mais que as obras não tivessem sido escolhidas por ela. Interessava-me saber se o processo seria apenas produtivo para quando o ator é detentor de todas as escolhas ou se era possível também construir conscientemente um trabalho autônomo e rico de significados - no caso da tradução intersemiótica - mesmo quando as escolhas são impostas pelo outro. 
Para esse ensaio, já como proposta de estímulo, a atriz trouxe a canção Guilty, de Al Bowlly, para seu aquecimento. Logo ao analisarmos as imagens de Toulouse-Lautrec, a atriz fez a escolha do primeiro signo: o bastidor - tentando, sobretudo, desmistificar a imagem de glamour que está associada ao Moulin Rouge, uma das casas que Toulouse mais frequentava. Assim, as ações que a atriz Patusca realizou eram da dançarina que se arrumava para antes de sair.

b) PROCEDIMENTO 2: Signos em Godard

- Atriz Patusca

- Exibição de trechos de filmes de Jean-Luc Godard

- Conceitos sobre linguagem e cinema

- Debate com a atriz

Nesse encontro, foi preciso retomar alguns conceitos que haviam sido expostos na primeira oficina sobre Estudos da Linguagem. É exatamente por esses movimentos e relações que se estabeleceram que eu penso no processo em rede. Quando voltamos a ver trechos de filmes do Godard, a atenção da atriz encaminhou-se mais para o filme Viver a Vida, o que me fez pensar em relações mais amplas entre os textos do pintor e do cineasta.

\section{c) PROCEDIMENTO 3: Encontro entre as atrizes}

- Apresentar para Christiane os resultados cênicos de Patusca

Após a apresentação dos resultados, comentamos sobre a escolha do signo bastidor, o que nos fez relembrar que essa era tanta uma vontade de pesquisa da Christiane quanto uma indicação que já estava na tela $A$ Roda, cujo título trazia a indicação "vista dos bastidores". Ou seja, Toulouse já apontava o seu ponto de vista, como sendo o ponto de vista do bastidor, já que ele era um grande frequentador dos cabarés.

\section{d) PROCEDIMENTO 4: Rever os materiais}


- Rever pinturas

- Rever filmes

- Estabelecer recortes

Com o signo do bastidor sendo um consenso, uma vontade comum, começamos a questionar se esse signo era recorrente em outros textos. Assim, nos deparamos com uma infinidade de pinturas, desenhos e rascunhos de Toulouse sobre o tema, bem como trechos de filmes de Godard onde o bastidor se convertia em intimidade - o mundo íntimo de seus personagens.

Nosso recorte seria mais específico: nas pinturas, o bastidor seria aquele presente nas telas em que Toulouse-Lautrec retratava o universo das maisons close - as Casas de Tolerância, como ficaram conhecidas - ao invés de focar naquele lado burlesco e glamouroso pelo qual ele ficou bastante conhecido ao pintar cenas de Moulin Rouge e outros cabarés; nos filmes de Godard, para pesquisar o feminino, escolhemos dois filmes em que Godard trata da mulher, sendo Uma mulher é uma mulher e Viver a Vida, tais filmes estabelecem também uma relação com a sexualidade feminina. Ocorreu-nos considerar Alphaville, também com Anna Karina, mas sua temática futurística não conseguiu criar pontes com o material que tínhamos, em termos de discurso.

\section{e) PROCEDIMENTO 5: Escolha de Signos}

- Escolher Signos

- Definir significados

Além do bastidor, foram eleitos nas pinturas de Toulouse: o divã, a cor vermelha, os tecidos, as meias, a sexualidade e a mulher. Nos filmes de Godard, escolhemos: o batom, o cigarro, a cor preta, o tempo, a morte, a sexualidade e o próprio cineasta Jean-Luc Godard - como o signo do autor, o homem.

Vejamos novamente o conceito de signo:

O signo é uma coisa que representa uma outra coisa: seu objeto. Ele só pode funcionar como signo se carregar esse poder de representar, substituir uma 
outra coisa diferente dele. Ora, o signo não é o objeto. Ele apenas está no lugar do objeto. Portanto ele só pode representar esse objeto de um certo modo e numa certa capacidade [...] substituem-na, apenas, cada um deles de um certo modo que depende da natureza do próprio signo. (SANTAELLA, 2007, p. 58)

Ela nos dá um exemplo:

\begin{abstract}
A palavra casa, a pintura de uma casa, o desenho de uma casa, a fotografia de uma casa, o esboço de uma casa, um filme de uma casa, a planta baixa de uma casa, a maquete de uma casa, ou mesmo o seu olhar para uma casa, são todos signos do objeto casa. Não são a própria casa, nem a ideia geral que temos da casa. Substituem-na, apenas, cada um deles de um certo modo que depende da natureza do próprio signo. A natureza de uma fotografia não é a mesma de uma planta baixa. (SANTAELLA, p. 58)
\end{abstract}

Há muitas definições de signos, dados por diferentes autores, embora a maioria deles faça referência, sobretudo, a Charles S. Peirce. Escolhi essa definição dada por Santaella por considerá-la bastante didática. É claro que ao falar de objeto, a autora refere-se de uma forma mais ampla àquela dimensão ao que o signo atribui significado, podendo ser tanto um objeto no sentido mais simples da palavra, como um batom, ou como uma dimensão mais abstrata como a morte ou o tempo. Ao falar da natureza do signo, a autora diz dos três tipos de signos: ícones, índices e símbolos.

Nas artes, é comum tratarmos os signos por símbolos, não somente por seu caráter arbitrário de lei e convenção, mas principalmente por sua amplitude de significados, sua representação geral. É como se o objeto representado pelo símbolo fosse tão geral quanto o próprio símbolo, a exemplo das palavras. Em nossas escolhas de signos, há objetos estetizados (divã, cigarro, tecidos, etc.) e palavras (sexualidade, morte, tempo, etc.).

Um símbolo não pode indicar uma coisa particular; ele denota uma espécie (um tipo de coisa). E não apenas isso. Ele mesmo é uma espécie e não uma coisa única. Você pode escrever a palavra estrela, mas isto não faz de você o criador da palavra - e mesmo que você a apague, ela não foi destruída. As palavras vivem nas mentes daqueles que as usam. Mesmo que eles estejam todos dormindo, elas vivem nas suas memórias. As palavras são tipos gerais e não individuais. (PEIRCE apud SANTAELLA, p. 68) 
Quando na pesquisa de morte, autor, tempo e sexualidade escolhemos tê-las como palavras, foi para estabelecer essa mesma relação que Peirce explica, sobre algo geral. De certa forma, com os objetos se deu o mesmo: não falamos desse ou daquele divã e cigarro, mas de como esse signo simboliza a recorrência/repetição do discurso a qual está atrelado, nos textos que escolhemos pesquisar.

\section{f) PROCEDIMENTO 6: Signo e Discurso}

- Análise do signo no discurso

- Análise do discurso revelado no signo

Fizemos muitos estudos como esse, formais e informais. Gostaria de expor a maioria no contexto da encenação. Portanto, apenas como exemplo do procedimento, eu comento, nesse subtópico, somente um.

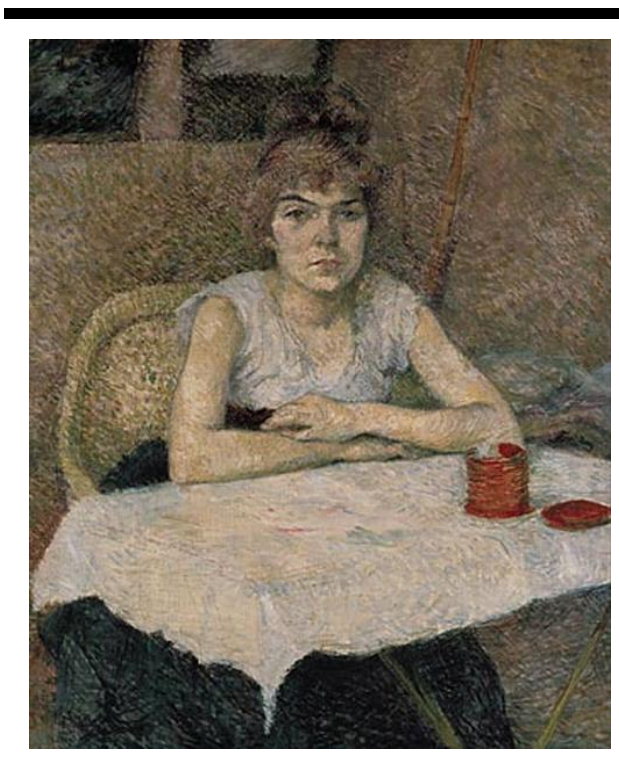

Poudre de Riz: "Provavelmente feita em 1887, a pintura representa uma transição da prática ortodoxa para preocupações mais experimentais. [...] 'Poudre de riz' também tentativamente explorava um uso intensificado de cores secundárias, tais como o subjulgado verde $e$ violeta, contrastantes ao fundo. [...] A modelo pode ter sido Suzanne Valadon. Entretanto, a figura é apenas apresentada ao espectador como um tipo anônimo, representando principalmente mulheres da classe baixa, pintadas em 1886-8." (1887- giz negro e óleo sobre tela)

Segundo alguns autores, em algumas das imagens no início da carreira em que Lautrec pinta pessoas da classe baixa, isso se dá menos por uma atitude de simpatia e identificação e mais por uma tomada implícita de autoridade. 
Nesse mesmo período, durante os anos de 1880 e 1890 ele exibiu em uma refinada e exclusiva galeria, ao mesmo tempo em que exibiu em um salão de independentes. Essa radical polarização, não se sabe se se deu por ingenuidade ou oportunismo. Nessa exibição, mostrou quadros de retratos de mulheres, algumas de sua família e outras do proletariado. Não se sabe também se para mostrar sua amplidão ou para causar contraste.

É provável que seu interesse pelas classes baixas possa ter sido colorido pela sua boa natureza e humanitarismo, mas pode também ter surgido da necessidade de uma identidade especialista no mercado da arte; e pode inclusive, como podemos notar, ter surgido por outras forças culturais da época. Mas é recorrente que em seu discurso sobre a mulher ele parece ter levado consigo sempre uma pretensão de poder e controle, tanto quanto um instinto de ostentação, que são característicos da aristocracia.

\subsection{Encenação}

Com o término das Oficinas Pedagógicas, nós demos início ao processo de criação dos exercícios cênicos, o que coincidiu com o retorno à pesquisa do encenador Fabiano Benigno.

Consideramos parte dessa etapa: os primeiros exercícios com as ações físicas, a elaboração de roteiros de cena, os ensaios com diretor e o processo de montagem propriamente dito. Assim, é nessa etapa que fazemos a análise dos documentos de processo do nosso dossiê. Aqui todos os registros nos interessam:

Tudo tem exatamente a mesma relevância para o crítico genético: tempo de verbo modificado, uma influência detectada, um pincel adaptado, um pequeno apontamento do ator na rubrica do dramaturgo. Todo detalhe, por menor que possa parecer, foi, um dia, importante para o artista e o será para o pesquisador (SALLES, 57).

Inicialmente, ao tratar da dramaturgia do ator descreverei os procedimentos que foram utilizados tanto por mim quanto pelo encenador, sempre que necessário, comentando as observações feitas pelas atrizes. Quando falarmos de cada exercício cênico em si, falaremos das relações em rede. Já ao 
tratar especificamente de cada atriz, veremos os instrumentos criados pelos próprios artistas para a construção intelectual, dessa forma, os nós, estarão mais claros.

\subsubsection{DRAMATURGIA DO ATOR}

Embora o termo dramaturgia do ator tenha sido cunhado por Eugene Barba, nos ensaios o que mais esteve presente na prática de interpretação foram as linhas das forças motivas e o método das ações físicas, desenvolvidos por Stanislávki. Sobretudo, este segundo, que está no livro A Construção da Personagem, onde o autor enfatiza a ação, nas dimensões de impulso e ritmo.

Nossa opção pela ação está tanto na possibilidade de fixar, reproduzir, repetir, quanto pela sua característica psicofísica, quando não há mais diferenças entre as ações internas e as ações externas, pois o que a primeira consegue em significado e intensidade a outra alcança em termos de expressão.

Com as linhas das forças motivas, o elemento do primeiro livro do autor russo que ficou mais conhecido foi a memória emotiva. Com a elaboração das ações físicas, compreende-se que o ator também usa as memórias físicas, ao utilizar procedimentos onde ele traz para o movimento, elementos criativos que estavam no seu subconsciente. Quando falamos em dramaturgia do ator, queremos dizer mais da postura de pesquisador que o ator toma para si e, além disso, da tentativa de concatenação dramatúrgica das ações em movimento.

\section{a) PROCEDIMENTO 1: Ações Físicas}

- Atrizes Christiane e Patusca

- Ações físicas

- Repetição

- Linha contínua de ações

- Inserção de signos

- Concatenação dramatúrgica

- Dramaturgia do ator 
Com esse procedimento, além de fixar uma partitura para a atriz, busquei trabalhar com as proximidades do nível referencial e metalinguístico da linguagem, pois identifiquei que apesar de serem distintos na maioria das ocorrências, em Toulouse-Lautrec e Godard eles estavam presentes lado a lado. E como nós estávamos ainda investigando qual o lugar da ação resultante em toda a dramaturgia e sua significação, tratava-se também de uma busca de referencialidade e metalinguagem.

$\mathrm{Na}$ tradução das pinturas o nível referencial é o da própria representatividade cênica, o acordar e o vestir-se propriamente ditos, enquanto que a metalinguagem aponta para o embate entre o móvel e o estático que acontece quando as Artes Plásticas encontram o Teatro.

Isso se repete como característica nas pinturas de Toulouse-Lautrec, em que o traço veloz, sugere tanto a agitada vida noturna parisiense, a vida instantânea e sua embriaguez, ao passo que são as marcas da própria pincelada do artista que usava o fundo da tela como elemento expressivo.

$\mathrm{Na}$ tradução do filme Une femme est une femme, buscamos elementos referenciais fora do ficcional para procurá-lo em todos os tipos de significação cinematográfica. Identificamos na titulação do filme - de natureza puramente informacional - um trabalho estético com a linguagem. É um elemento chave para o texto fílmico em si, pois apresenta uma sequência de palavras-chave que dizem sobre o filme.

Nas cores branco, azul e vermelho, Godard coloca o créditos: Il était / Une fois / Beauregard / Eastmancolor / Ponti / Franchement Scope / Godard / Comédie / Française / Coutard / Musical / Legrand / Théâtral /Evein / Sentimental / Guillemont / Opéra / Lubitsch / 14 Juillet / Cinéma / Brialy / Karina / Belmondo - são referências diretas aos artistas envolvidos e os temas em questão ${ }^{28}$.

Metalinguisticamente, destaca-se o uso da trilha sonora, tanto como fundo aos títulos (sons de bastidores, de ensaios, do set de filmagem) e a

\footnotetext{
28 Ver trecho no DVD Anexos.
} 
composição sonora da cena. Em Une femme est une femme, a trilha destaca-se pelos cortes abruptos, pela suspensão sonora e pela dramaticidade sonora em confronto com a cena em si, como nas vezes em que sons típicos da significação do suspense ou na anunciação são usados pala dialogar com cenas cotidianas e com um enquadramento aparentemente sem a mesma leitura.

A atriz Christiane usou a titulação do Godard como abertura de sua cena, usando os comandos sonoros de Lights, Camera e Action para marcação das ações físicas e mudanças de estados.

\section{b) PROCEDIMENTO 2: Demonstração do exercício}

- Abertura do processo

- Demonstração do exercício

- Uso de todos os objetos e elementos de cena

- Debate após demonstração

- Orientação acadêmica

O CEPECA é o Centro de Pesquisa e Experimentação Cênica do Ator, do qual sou membro desde o final do ano de 2009. O Centro é coordenado pelo Prof. $\mathrm{Dr}^{\mathrm{o}}$ Armando Sérgio da Silva e pelo Prof. $\mathrm{Dr}^{\mathrm{O}}$ Eduardo Coutinho. Semanalmente, vários pesquisadores são orientados pelo coletivo, que conta com acadêmicos e ouvintes, cujo ponto em comum é serem interessados em investigar a arte do ator.

Nesse contexto fiz minha primeira abertura de processo ao grupo após a entrada da segunda atriz. O objetivo principal era demonstrar as diferentes leituras e dramaturgias que um mesmo exercício possibilitou ao passo que me interessava como retorno saber se as qualidades essenciais das linguagens estavam presentes. Caso estivessem, que tipo de qualidade que a tradução trazia para a cena e, em caso de negativa, como os procedimentos poderiam ser reajustados. As cenas de Patusca e Christiane podem ser vistas no DVD Anexos. 
Pelas ações de Christiane, podemos ver que ela propôs o acordar, pela experimentação de posições e apoios no divã. Durante os ensaios, ela chegou a uma partitura de sono incômodo, que mais adiante chamamos de insônia. Diferentemente, Patusca propôs que na sua ação o acordar seria de uma noite anterior com um homem. Christiane também buscou traduzir a tela Etude de $\mathrm{Nu}$ (1893), onde a pose relaxada da modelo, e sua timidez ou modéstia, representam tradicionalmente atitudes 'femininas'. (Figura 28)

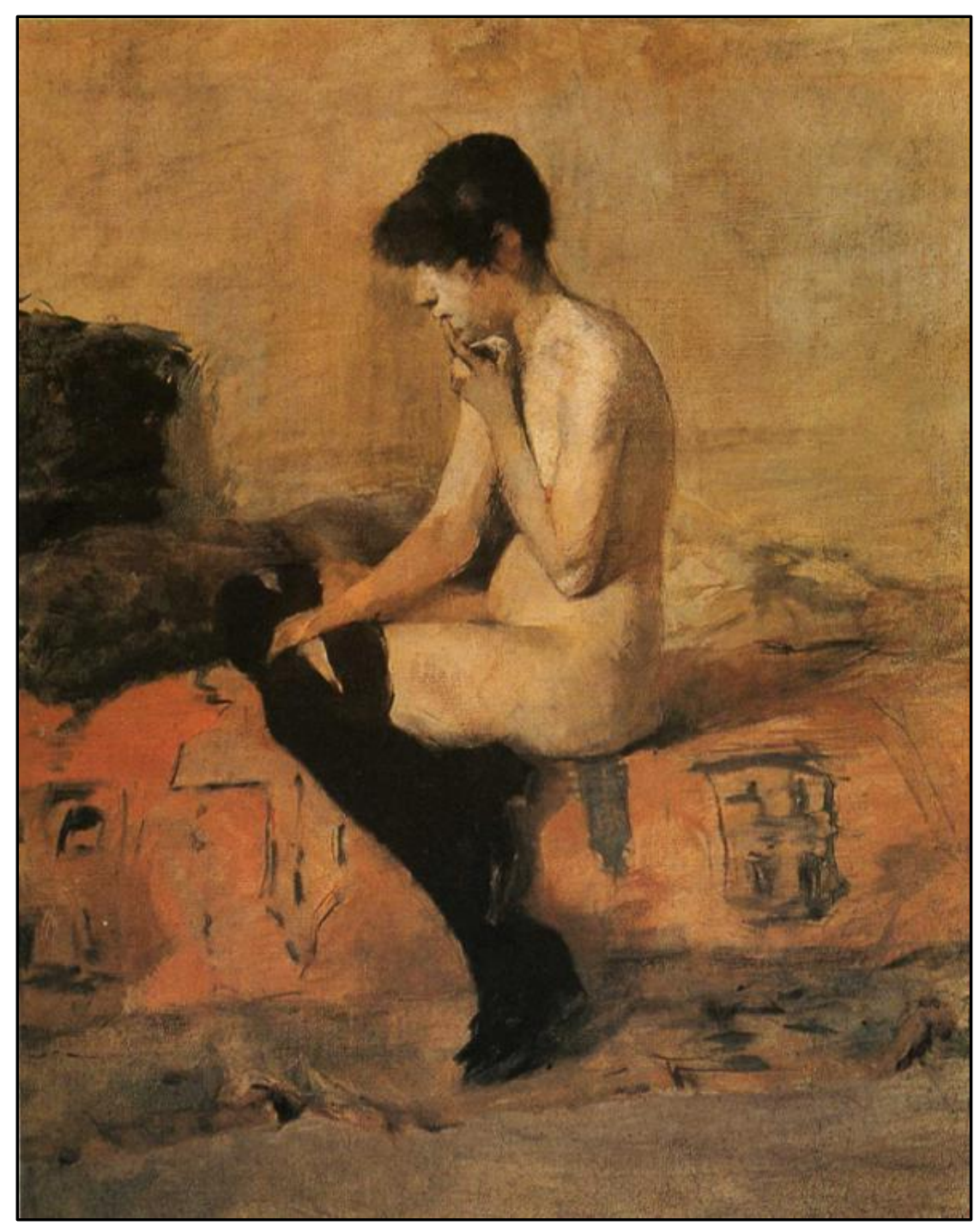

Figura 28: Etude de Nu - TOULOUSE-LAUTREC (Fonte: Arquivo Pessoal)

Nós tivemos dois tipos de recepção, uma com relação ao discurso e outra com relação à Tradução Intersemiótica em si. Sobre o discurso, o que mais chamou atenção foi o enfoque que as atrizes quiseram dar para o universo feminino retratado, que era o bastidor de acordar e arrumar-se. Por serem dançarinas, mulheres da noite, esperava-se que houvesse uma leitura sobre a 
sensualidade, porém com o enfoque no bastidor, as atrizes desejavam uma leitura oposta a essa.

Por outro lado, depois e nosso ensaio chegamos à conclusão que essa recepção também é pertinente, pois ainda que as atrizes estejam tratando do século XIX, onde as condições higiênicas e de saúde pública eram precárias, é importante ressaltar que ainda assim num ambiente de cabaré, tal como Toulouse-Lautrec o retratou, a sensualidade está presente, portanto seria uma questão a se pensar onde esse signo se perdeu na leitura e se era preciso revê-lo.

Com relação à pesquisa em si, sobre a tradução intersemiótica e sua qualidade em cena, a principal observação foi sobre aprofundar nas qualidades essenciais de cada arte. No caso das Artes Plásticas, o fato de ela fixar o momento, nos possibilitando olhar calmamente, imaginando o passado e o futuro. Assim como, a perfeição da composição do gesto, o uso das cores e, por fim, a possibilidade do estático. O mesmo ocorre com o cinema e a montagem.

Para outros pesquisadores, o que fica de mais importante não é a referência direta em si, que ficou clara, mas a possibilidade de ao mesmo tempo fazer a tradução intersemiótica e traduzir a discussão que os artistas tinham sobre a arte deles para a minha discussão. Ou seja, com referência ao uso da trilha sonora de Une femme est une femme, em que o Godard usa a sonoridade recortada, independente da gramática que se instaura na cinematografia, isso é uma discussão que o Godard está fazendo com a linguagem dele.

Mais que isso, considero importante o uso do signo Godard, do autor. É nesse tipo de recepção que ele aparece. O cineasta afirma de tal forma o seu olhar que a relação metonímica é recorrente. A sugestão seria pensar como a discussão que o Godard põe para o cinema seria possível no Teatro.

É interessante pensar que ele apresenta uma forma de olhar, pois é uma discussão poética que ampara a criação de uma obra de arte no teatro. Nesse caso, é uma chave dada pela própria tradução e não dos artistas escolhidos, pois a concretude está no texto e nos signos. Não é preciso escolher textos convergentes, mas fazer convergirem as questões do texto. 
c) PROCEDIMENTO 3: Elaboração do Roteiro de Ações

A criação do roteiro de ações é um procedimento pedagógico, que tem como finalidade organizar em formato de roteiro de ação as ideias para cena, as questões problematizadas pelas leituras de cada atriz. Seguem-se também princípios teóricos, estéticos e de tradução para melhor preparação do roteiro, do roteiro inicial. As atrizes constroem cenas, ações, mas também ficcionam e todo esse material é utilizado na preparação.

O roteiro de ações é uma primeira equação dessa tradução que envolve linguagens, técnicas, estilos e até discursos antagônicos. O roteiro torna visível de forma concreta a unidade estética e textual que se busca na criação. É o primeiro documento desse processo. Naturalmente, ele iria ser alterado, haja vista, que é um pré-roteiro para a dramaturgia de cena. É a cena que a ele responde, pelo jogo, pelas ações e pelas outras camadas de encenação.

A versão que mais utilizamos durante os ensaios está nos anexos.

\subsubsection{Christiane Martins}

\section{a) PROCEDIMENTO 1: Encontro com Encenador}

- Cena da atriz Christiane

- Rever referências: filmes e pinturas

- Debater Roteiro de ações

Após a apresentação da cena, o encenador fez alguns questionamentos sobre o processo, e logo iniciamos o estudo das referências para entender como elas apareciam na cena. A seguir, há trechos transcritos de nossas falas no encontro, seguida dos comentários.

Fabiano comenta sobre o signo cigarro. Explico que é uma referência ao cinema noir e que, tecnicamente, usa-se um filtro para a câmera que implicava em uma outra textura, por isso a fumaça ficava também mais volumosa. 
Eu gosto exatamente por causa disso, porque com a Luz isso também cria uma atmosfera... Daí você pensa, 'que espaço é esse; o que essas mulheres estão vivenciando; isso é um sonho, isso é realidade'; Eu trabalho muito com luz, como ator e diretor, eu concebo a cena sempre pensando na luz. Eu não consigo pensar a cena sem luz, alguns diretores criam pensando no cenário. Quando criam já vem um cenário, para saber que espaço é esse... Eu vejo a luz. Onde pode ter uma luz, onde a luz pode ajudar a cena a saltar. (FABIANO)

Comento que o cinema, sendo 'a arte do diretor', trata da condução do olhar, e o questiono sobre como trabalhar a tradução da condução do olhar. E ele responde que pode ser exatamente com o uso da luz, do foco, que é uma das formas de conduzir o olhar no teatro. A atriz nos lembra de que pode ser igualmente pelo olhar do ator como uma ação, pois o olhar do ator aponta também uma intenção e uma direção para o espectador.

Agora, comentamos sobre o signo do bastidor e as leituras que cada atriz deu.

Vejo a Patusca mais 'escrachada' e você com os movimentos mais pontuados. Ele revela essa mulher que precisa abrir brechas, a mulher sem pudor. E aí, é possível ver uma força nesse bastidor mesmo. É escrachado, não tem um pudor, mas ao mesmo tempo se revela a sexualidade da mulher. Essa mulher no dia-adia. Quando eu vejo a tua figura (Chris) nesse espaço, eu vejo uma contradição que pode ser interessante, interno. Pode ser a verberação desse interno da mulher, do desejo de se encaixar nas convenções. Mulher polida. Daí a gente pode investigar em que momento, em você, pode ter essas explosões. Em que momento essas explosões podem acontecer. Em que momento nela aparece essa polidez. (FABIANO)

Christiane comenta que é possível pensar nos diferentes universos dos textos. Em Godard, por mais que o desenho da personagem Nana seja como uma prostituta, nós vimos em sua trajetória que foi uma escolha, em busca de facilidade. Antes disso ela trabalhava em uma loja de discos e achava que era mais fácil ser prostituta. Já essas mulheres que a Patusca representa não tinham essa escolha.

O encenador explica que independente desses dois universos há algo que está presentes e que como pesquisa o interessa muito.

E estou falando isso sobre a mulher por que tem algo que me interessa muito que é a força da mulher. Onde está a força da mulher? Onde ela aparece? Onde ela se revela? Onde está? Seria interessante e eu vou propor que vocês mostrem 
isso na cena. Já está tudo aí. Vamos aprofundar na pergunta, no discurso, no conteúdo. É importante para dar sentido à pesquisa. Onde está essa força? Como eu me sinto na relação com o mundo? (FABIANO)

Voltamos a retomar as perguntas de pesquisa para a cena, que havíamos feito no momento dos workshops. Sobre a força, Christiane comenta que a personagem Nana é com quem ela mais se interessa para investigar esse estado.

Esse filme é muito engraçado por que eu comecei assistir achando que alguma coisa ia acontecer com ela, pensei 'ela não vai ficar assim, tem alguma coisa no fim', mas ela morre no fim. Tem uma cliente que quer casar com ela, então o tempo inteiro parece que vai acontecer algo e... ela morre. Ela quer ser atriz, a sensação que a gente tem é que algo vai acontecer, daí começa a rotina e fim. Nada acontece. Ela morre assim. Me ocorre que essa morte seja algo de negar a força feminina. De o Godard, por ser existencialista, meio que anula isso. [...] É o que ele faz com a Ângela em 'Uma mulher é Uma mulher'. O filme inteiro ela quer ter um filho e quer ter o reconhecimento do amor. Na verdade, ela quer casar e ser mãe e no fim, o namorado diz que não vai casar, que não quer ter filho e ela aceita. Às vezes o Godard, desdiz, porque ele mostra que essa mulher pensa. Ela quer casar, ser mãe, tem útero, mas também pensa. E isso até hoje. $O$ fato de ela querer dançar mostra essa liberdade de querer ser alguma coisa. Ele desdiz todo esse movimento feminista da época. Por mais que tenha alguma aprovação da libertação das mulheres, ele também tem um lado bem machista. É que mulher é frágil. Ela perdeu a disputa. E ele coloca a traição quase como um charme. (CHRISTIANE)

A atriz esclarece a escolha por Godard e por Viver a Vida. Em relação ao primeiro ela diz ter a ver com a linguagem: “Quando a gente, na ação, congela é porque há algo ali, um pensamento. Ela, a Nana mesmo, se questiona o filme inteiro. Volta e meia ela pergunta o porquê". Já sobre as artes plásticas, ela aponta as pinturas como criando a atmosfera visual e plástica. E continua, sobre o cinema: "nós tínhamos pensando nos diálogos do Godard. [...] Daí surgiu a discussão se seria esse texto, se a gente se apropria desse texto, ou cria um outro texto. O que me preocupa é a questão do tempo." 
Digo que é possível que surja um texto a partir da ação física, já que todos os procedimentos que eu tentei foi no sentindo de aproximar a linguagem do cinema e das artes plásticas, mas alerto o encenador de que eu não havia elaborado nenhum procedimento que trouxesse a palavra.

Fabiano nos pergunta como chegamos ao roteiro e a essa relação. Quer saber se houve algum jogo antes entre as atrizes. E quais outras referências usamos. Explico sobre o procedimento das ações aplicado individualmente e falo da imagem de a mulher que ri, de onde retiramos o estímulo do corte e da morte.

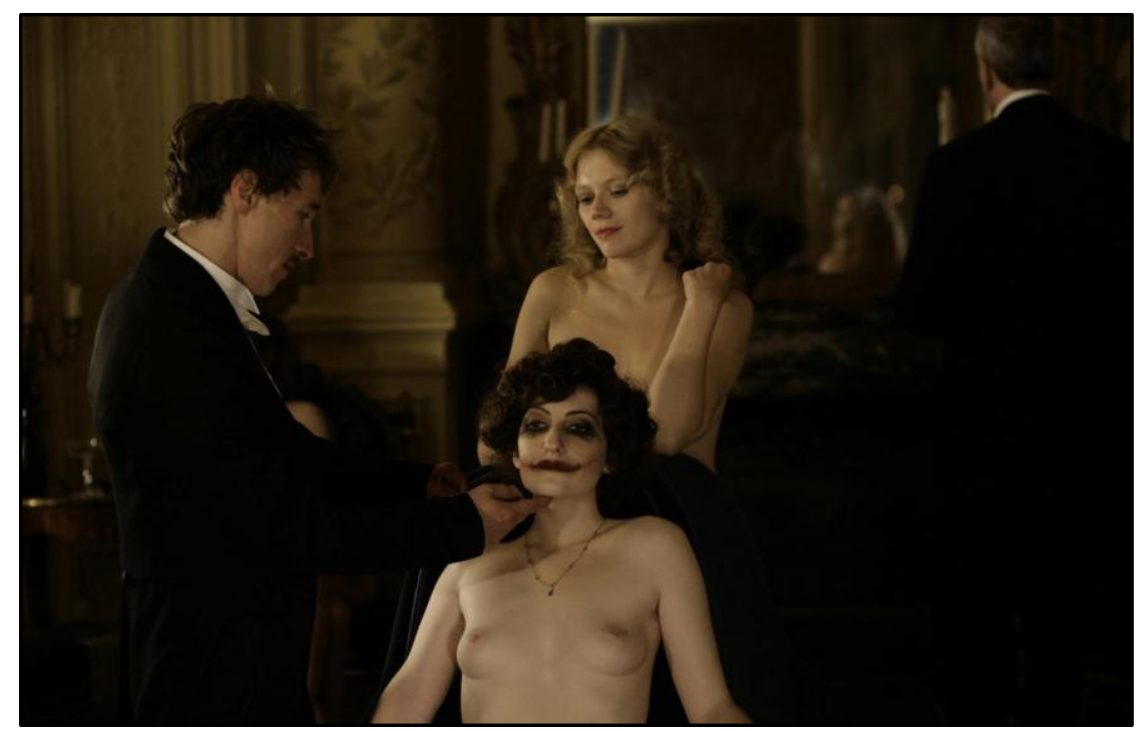

Figura 29: Le femme qui rit - L'APOLLONIDE (Fonte: Arquivo pessoal)

Fabiano explica:

Talvez o tempo não comporte essa dramaturgia. Talvez o tempo de quarenta e cinco minutos não seja o tempo ideal para dar conta desse conflito. Como pode ficar interessante o trabalho para dar conta dessas questões que estão sendo levantadas? Esse tipo de imagem (mulher que ri) me soa muito mais interessante do que criar uma estória. Criar possibilidades de leitura que essas figuras podem ser as mesmas. Se são diferentes, há reverberação e uma para a outra? Acho que a gente pode ir para o movimento - essas partituras que as atrizes criaram - para pode gerar mesmo essa dramaturgia na cena. [...] Pode ser interessante a Chris ter essa maquiagem o tempo todo. Você começa de costas, você tem essa placidez, mas quando você vira revela essa figura. Que está mais séria, mas é uma maquiagem que sorri. É aí que está o conflito. Gera possibilidades de leituras para quem vê, a dramaturgia ser justamente esse conflito interno que pode ter a ver com a movimentação das duas, em cena. Que pode ter o diálogo com palavras, ou não. O público que construa a possibilidade: "O que será que vai acontecer?" Ao invés de isso estar dito. (FABIANO) 
Digo que ainda sim foi uma etapa importante termos passado pela elaboração do roteiro e a atriz concorda, afirmando que as relações que ficaram já estavam estabelecidas: “Já começo a pensar na personalidade dessa personagem. Como é que ela poderia ser toda extrovertida com um rosto desses? Como é que ela não iria cobrar do homem. Isso revela um psicológico", um subtexto.

O encenador comenta sobre a ação dessa figura.

Na forma como ela pega os objetos, na forma em que ela tira o vestido e vai se maquiar, no gestual dela, você vê outra coisa. A contradição do que está antes. Pode criar essa história internamente, mas isso não precisa aparecer na cena. Mas ter um motivo que sustente essas figuras. É por isso que chamo de figura e não de personagem, pois o personagem precisaria ter. Acho que vai ser mais interessante para as atrizes brincarem com isso na cena e vai deixar mais evidente a tua pesquisa. [...] Mantemos a cena inicial e vamos mesclando. (FABIANO)

\section{b) PROCEDIMENTO 2: Pesquisa e Criação}

Após seu encontro com o encenador, Christiane dedicou-se à construção daquela figura em oposição àquela que Patusca pesquisava. Para isso, aproximou-se mais dos signos cinematográficos do filme Viver a Vida.

A citação a seguir é trecho de uma análise sobre o filme que se aproxima muito à nossa leitura sobre o mesmo:

Viver o cinema - não é outra a coerência de Godard, ao dedicar Viver a Vida às produções B americanas, assim como, em Acossado, já fizera sua dedicatória à Monogram Pictures. Viver a vida $x$ viver o cinema - a dialética radial onde cinema e vida se misturam, transmutam-se mutuamente, - a cinevida. E temos a vida do artista, da mulher, da meretriz, do cineasta, do homem, do crítico, tudo na autocinebiografia espiritual que, como leitmotiv, é Viver a Vida, a cinevie - a vida em movimento, para dentro e para fora da tela. [...] Daí em diante, vida e arte estão focadas mediante constantes interpenetrações, como se o autor estivesse querendo destruir o mito de 'objeto de arte', aquela aura que envolvia a coisa. Viver é uma arte - daí porque Godard sempre foi o cineasta essencial do comportamento, do estar, do respirar fenomenológico, e não das prédefinições, do ser, da estratificação dos conceitos, que isolam o cinema do espectador. [...] Pensamos sobre a vida: O que é a vida? Aonde vai a vida? Logo depois, ela morre, como num documentário - filmagem seca, o antidrama, a antitrama, a antitragédia, a anti-história - é a história de um espírito, do diretor. Viver a vida representa a objetividade total, viver-estar, síntese de um processo que se desenvolve a cada fração de espaço-tempo. E aí temos o 
autonomeado filme concreto, segundo o próprio cineasta. Cinema concreto seria aquele que se refere a si próprio, que inaugura uma experiência em vez de traduzir experiências. [...] Mas a força da sétima arte é total. Hoje, poder-se-ia ainda, nessa superposição de dialéticas, colocar-se outra: a intelectual da invenção e a sensorial, das formas, da magia do espetáculo. Não é de se desprezar esta última, que representa o cinema em sua essência moto-visualsonora. (GRÜNEWALD, p.141-142)

Em uma conversa que tive com Christiane nesse período, ela faz reflexões sobre suas escolhas de textos, como a leitura e consequentemente o discurso que ela quer por em cena, foi mudando.

Ela começa falando sobre os filmes, que mudaram de Maria Antonieta, de Sophia Coppola, para os filmes de Godard.

Naquele momento eu relacionava muito com Maria Antonieta, porque eu via muito essa coisa do vestido, da cor, que são esses tons meio pastéis. É o que o Toulouse usa e era o que a Maria Antonieta usava. O sapatinho, o vestido, o volume. Era com essas coisas. O cabelo loiro. Mas depois quando eu tive essa familiaridade com a Löie, quem era essa mulher na verdade, isso já transformou... Era não era loira, era morena. Aquele vestido não era de cancã, era provavelmente um tecido muito mais leve. Isso aí já muda. Eu olho para aquela tela e, realmente, eu não consigo mais voltar a olhar da maneira que eu olhava antes. Hoje em dia já me desperta outras coisas. Quando vem o Godard, eu já começo a pensar nessa mulher, não na mulher da tela, mas essa mulher a Löie. (CHRISTIANE)

Pergunto como ela se afeiçoou ao universo do Godard, quando eu apresentei Uma mulher é uma mulher.

Eu acho que é porque eu estava sentindo de um tema e uma direção, e do Godard eu acho que eu encontrei isso. [...] Ele consegue falar do Feminino também, porém ele tem um direcionamento, tem um personagem. Isso que eu sentia falta que a gente não tinha, olhando só para a tela. (CHRISTIANE)

Comento que talvez esse seja um posicionamento dela no processo de ter achado melhor criar a partir do Cinema do que das Artes Plásticas, porque o cinema traz mais informação. Ela diz: “Sim, mas esse universo todo só surgiu por causa da tela, ele não está no filme. O universo que a gente traz aqui, no Viver a Vida ele não existe." E completa: “Isso vem da tela, porque daí a gente 
fez uma relação com a Löie e as pinturas do Toulouse, e essa coisa da 'podridão' que existia bem na época, que deixou de existir depois.".

Ela fala sobre seu interesse pelos filmes do Godard, a partir do da proposta que eu fiz quando mostrei Uma mulher é Uma mulher, e como outras referências entraram na pesquisa e construção.

Assistindo ao filme do Godard, fui vendo aqueles universos, eu começo apensar assim: 'Que discurso que eu quero falar hoje?' Antes eu estava pensando muito naquela coisa da Maria Antonieta, porque eu estava focando muito em imagem. A ideia de um teatro de imagem era um universo maravilhoso, muitas coisas, o glamour, muito material, mas depois eu fiquei pensando: 'como posso transformar isso em discurso que seja interessante?' Faltava alguma coisa, eu não via, não tinha interesse nisso. Quando eu vejo o Godard, quando eu vejo a Anna Karina, eu vejo que ele pega uma coisa super comum, mas vejo que ele coloca um discurso muito forte ali. As palavras que ela diz, principalmente no Viver a Vida - mais do que em Uma Mulher é Uma Mulher - aquilo todo mundo pensa isso hoje ainda. Pode ter tido a revolução do sexo, do movimento feminista, mas mesmo assim, quem é a pessoa que nunca parou para pensar nas coisas que a Anna Karina fala em Viver a Vida? [...] Os fatos da vida dela, não evitam dela se questionar. Quando eu assisti ao filme Moulin Rouge de 1952, eu penso a mesma coisa. Quando mostra a Marie - mulher pela qual Toulouse se apaixonou - e aquela que se tornou amiga dele, ela era uma mulher de classe, mas ela nasceu lá naquele universo, ela costurava, pregava botão, fazia luva. Ela ganhava o dinheiro dela limpo, de forma honesta. Enquanto a outra era uma vigarista. (CHRISTIANE)

Com relação ao filme de John Huston de 1952, Christiane explica sobre uma visão que contrasta com o determinismo naturalista. É exatamente essa característica que ela observa nas tentativas da personagem Nana, em Viver a $V i d a$, que, nas poucas e pontuais falas que tem ao longo do filme, se questiona sobre a vida e faz reflexões existencialistas.

A atriz, então, conclui suas observações sobre o processo, no momento em que estávamos de começar o trabalho com o encenador:

O resultado da dramaturgia do ator foi isso, nós temos um roteiro. A gente chegou nisso através das imagens, através do treino, mas agora penso que o que temos com o roteiro é um teatro pós-dramático, nós não temos as falas. A gente está contaminada por tudo aquilo que a gente leu. Agora eu sinto que preciso do Fabiano. (CHRISTIANE) 


\subsubsection{Patusca}

\section{a) PROCEDIMENTO 1: Encontro com encenador}

Iniciamos o encontro com a apresentação da cena desenvolvida pela Patusca, seguido de uma conversa sobre a forma com que o encenador desejaria proceder. A seguir, há trechos de nossas falamos, com observações sempre que necessário.

Fabiano inicialmente comenta a diferença entre a música que a atriz trouxe como estímulo e aquela que havia escutado na cena de Christiane, esclarecendo que elas trazem atmosferas diferentes. Em seguida, explica para a atriz a proposta de não utilizarmos o roteiro de ações.

Penso que não dá para contar essa história em uma hora, que seja, pois eu vejo figuras. É igual ao próprio quadro, você olha e já tem de imediato a leitura dessa figura. Identifica. No meio disso, penso em propor leituras para o público, deixar que ele crie a própria história no meio desse devaneio. Porque eu percebo uma atmosfera de sonho, esfumaçada, uma realidade que não é daqui, por isso é bom o signo do cigarro, além de tudo, a fumaça desenha a luz. E não penso em definir se elas são amigas, se elas são a mesma pessoa. [...] Deixar que a plateia crie sua própria história a partir dessa vivência, porque a Chris pode ser, inclusive, uma reverberação da tua figura, ou vice e versa. [...] Para mim, aquela figura já está inserida (refere-se à 'mulher que ri') porque é interessante demais. Eu acho que esse conflito tem que se gerar, e nasce a dramaturgia dos atores. (FABIANO)

A atriz, então, reafirma que na construção dessa figura pretende aprofundar o signo do bastidor: "Eu estudei muito o Toulouse na universidade. As pessoas olham os quadros deles e ficam com aquela imagem do Moulin Rouge, do mágico", e enfatiza o lado histórico:

[...] Mas o que eu quis mostrar era a coisa podre. Dizem ‘Não, essas mulheres eram lindas' E eu falo: 'essas mulheres tinham sífilis, essas mulheres morriam todas feridentas, tinham o dente podre... elas apanhavam e tinham um prazo de validade'. Eles querem ver uma coisa do quadro, que é linda, mas eu quero mostrar a putrefação. (PATUSCA)

Assim, fica mais uma vez estabelecido o recorte que daríamos sobre as pinturas de Toulouse-Lautrec, os bastidores das Casas de Tolerância. Sobre a 
relação entre as duas cenas, o encenador comenta que a atriz traz uma característica de humor que é bem vinda, pois o filme Une femme... também usa caracteres cômicos.

Ele também afirma que há outras coisas que ela trouxe para a cena que também geram leitura e, portanto, dramaturgia. Ele cita como exemplo o momento em que ela sai de cena para amarrar o cabelo e voltar pronta. Como não tínhamos cochia, a atriz fez em um canto separado da sala de ensaio e o encenador gostou da imagem, para ele é uma figura que se constrói em cena.

A atriz comenta: "Eu nunca tinha pensado como esse cabelo é emblemático. Eu estou tão impregnada com as coisas dele, que faço sem perceber. Isso fica no ator." Aqui, ela refere-se a um penteado recorrente nas mulheres pintadas por Toulouse.

\section{b) PROCEDIMENTO 2: Pesquisa e Construção}

A atriz produziu alguns textos, inspirados nas telas e nos ensaios, como uma forma de auxiliar seu processo de construção da figura feminina. Dentre eles, podemos destacar três, que podem ser lidos nos anexos.

\subsubsection{3. "Efêma"- plasticidade e poesia}

Neste subcapítulo, gostaria de expor quais foram as operações genéticas que conseguimos identificar a partir do que mostram os documentos do processo, sobre a construção do primeiro exercício cênico, intitulado "Efêmea":

\section{a) Sintese}

Houve síntese desde o primeiro ensaio. Há passagens que ilustram isso. Podemos destacar dois momentos emblemáticos, nos vídeos 1 e 2, em anexo. ${ }^{29}$ No vídeo 1, por volta do minuto 5', a atriz Patusca improvisa a escolha da roupa que será usada em cena. Ela descarta o vestido vermelho com longa saia branca. Em seguida, vê uma roupa mais simples, para a qual ela até olha com

${ }^{29}$ Os dois vídeos estão no DVD Anexos, no item Ensaios, do menu. Já as fotografias de ensaio, podem ser vistas em Anexos. 
interesse, mas com uma observação mais detalhada ela julga inapropriada. Experimenta também um longo vestido amarelo, mas ele parece muito exuberante. É quando ela percebe um vestido preto. Experimenta-o, nota uma mancha e tenta com afinco removê-la e não consegue. Porém, mesmo manchado, ela elege o vestido preto para si.

Aqui temos no vestido a relação metafórica do recorte que fizemos com referência aos textos de Toulouse- Lautrec e àquela que acabamos fazendo sobre nossa estética. Vemos no primeiro vestido uma alusão aos famosos modelos usados por Jane Avril, estrela do Moulin Rouge, retratada pelo pintor Toulouse-Lautrec. Com o segundo, há a discurso de que não se trata, nesse momento, de uma leitura necessariamente histórica do período. Já o terceiro vestido, reafirma o recorte feito sobre as pinturas do artista que privilegia o ambiente da maison close, em detrimento das famosas litografias do pintor, nas quais as cores fortes e saturadas são a marca.

Quando a atriz escolhe o vestido preto, ela declara sua opção pela sintese: é a cor preta como signo sombrio dessas figuras que vagam por um cabaré desabitado e onírico; é também signo da roupa preta de trabalho do ator, como uma forma de explicitar o resultado como um exercício cênico.

Esse vídeo é o um trecho do primeiro ensaio com o encenador Fabiano Benigno, onde as atrizes fizeram uma improvisação a partir do roteiro de cena que tínhamos elaborado. Nesse momento, algumas escolhas ainda eram inconscientes, mas já apontavam, como índices, para o que as atrizes queriam dizer sobre os textos.

O vestido preto, como um luto, ficou sendo uma negação da imagem glamourosa que se atribui às pinturas de Lautrec. Mas para frente, vemos que fomos cada vez mais abandonando elementos de figurino, mesmo aqueles que eram objeto de cena para adotar o preto como uma forma de retirar a aura de 'objeto de arte' que há sobre a cena, igualmente como tentou fazer Godard, ao 
revelar a impossibilidade ontológica do cinema. Assim, nós espetacularizamos também o nosso bastidor, tal qual Toulouse-Lautrec o fez em suas pinturas ${ }^{30}$.

Ainda nesse ensaio, Fabiano sugere que Christiane use o mesmo vestido escolhido por Patusca, retirando do cenário, parte dos vestidos que causavam volume. Assim, a cena foi ficando mais limpa e daí para frente muitas das ações que se fez foi em busca da síntese, seja do signo, seja do discurso.

Outro exemplo de síntese, de acordo com o vídeo 2, é a radicalização desta operação quando muitos dos elementos de cena são retirados, restando apenas uma penteadeira, um divã e o vestido preto.

\section{b) Ação dos signos}

Aqui, refiro-me às ações a que as atrizes chegaram após experimentar com os signos escolhidos. O uso do cigarro, do batom, do divã, etc. Nós, por exemplo, colocamos rodinhas no divã, para poder fazer uso de movimento de câmera, como o travelling. Assim, as atrizes se movimentariam dando a mesma ilusão que a câmera dá ao fazer seus movimentos, ela confere tempo ao espaço. Com o uso da arena e as rodas nós tentamos realizar uma panorâmica.

\section{c) Signo das ações}

Os movimentos que a atriz propunha geravam leitura para todos nós que estávamos no ensaio e que conheciam os textos, assim, pela ação física, pelos improvisos, nós íamos dando as leituras e o Fabiano teve papel importantíssimo, pois, como encenador, a leitura espetacular foi assinada por ele.

Em alguns momentos, em razão do que as atrizes propunham no ensaio, Fabiano deu indicações tais como: fazer o movimento em câmera lenta, formar

\footnotetext{
30 O crítico Arthur Huc classificou Lautrec como "néo-réalistes". De acordo com ele, esses pintores todos usam um procédé de synthèse (processo de síntese), eles tratavam o mundo moderno com uma observação aguçada e até caricatural. Ele se distingue pela sua síntese de linhas, seus instintos por caricaturar, suas elisões de meios e imaginários das belas artes e ilustração. Para retratar Montmartre, Lautrec aperfeiçoou suas habilidades, articulando os seus poderes intensos e espirituosos de observação pelo uso muito pessoal da cor e linha: forte, resistente, ampla, nunca um desperdício.
} 
fotografias, pausar, dar tempo para reconhecermos as telas. Assim, são as ações que levam o encenador e os atores à construção do signo.

\section{d) Espelhamento}

O que nós apenas indicávamos nos primeiros ensaios foi o que fizemos mais a frente para as apresentações. O espelhamento aconteceu, sobretudo, quando assumimos uma postura de arena com o público em todos os lados da sala. Assim, usamos duas penteadeiras e tomamos uma direção diagonal. Com o uso de tecido branco, criamos o efeito de projeção da sombra, o que duplicaria a imagem, dando para ela uma silhueta que revelaria apenas a forma, enquanto que a figura em si, mostraria o bastidor, o gesto ${ }^{31}$.

\section{e) Contraponto}

Esse é um desdobramento do espelhamento. Conforme o vídeo do Exame de Qualificação, ${ }^{32}$ há uma cena em que as duas atrizes vão à janela, porém, uma fecha-a enquanto a outra abre. Enquanto uma depara-se com o entardecer, com o signo de que é preciso começar o dia de trabalho à noite, a outra se fecha em seu quarto, ainda não sabemos o porquê, mas logo somos levados a saber que ela tem o rosto cortado, que ela se fecha exatamente no momento em que as outras mulheres se expõem. Uma senta-se na cama para se vestir enquanto a outra se senta por puro tédio, para fazer nada.

O vestido do qual Christiane despede-se é o vestido que Patusca pega para começar a noite. Assim também quando as atrizes trocam de lugar na cena, Patusca vai para o divã e Christiane vai para a penteadeira, revelamos que cada uma das duas possuem em si os dois estados opostos - onde a primeira assume também seu lado de tédio, seu lado existencialista e a outra ao tocar no seio e maquiar-se também nos informa sua condição de mulher.

Christiane põe as luvas como se fosse sair, mas ela não irá sair, por isso, ela tira as luvas e joga para trás. Patusca pega as luvas, ela irá sair para trabalhar, lá

\footnotetext{
31 O exemplo das sombras no tecido branco pode ser visto no vídeo 'Mostra CEPECA de Recortes Espetaculares', no DVD Anexos.

32 O vídeo ‘Exame de Qualificação' pode ser visto no DVD Anexos.
} 
fora está frio. Mas ela joga-se ao chão. Aqui vemos o contraponto pela oposição e a acentuação das características do decadentismo em Toulouse.

\section{f) Simultaneidade}

Refiro-me as ações que acontecem ao mesmo tempo. Algumas vezes em ações distintas, outras onde há semelhança. Como quando as atrizes dizem o mesmo texto:

Nada. Eu queria dizer essas frases com palavras que fossem precisas. Eu já não sei mais qual é a melhor forma de exprimir essa ideia. Eu sabia, mas agora eu já não sei mais. Justamente! Isso não acontece com você? Isso é sério! Será que podemos falar de algo que não seja você mesma? ${ }^{33}$

Essa frase surgiu quando o encenador pergunta se há palavras, frases dos textos que sugere algo às atrizes. Christiane relembra de uma frase dita pela personagem Nana, em Viver a Vida: “Eu sou responsável por tudo o que faço. Se eu levanto a minha mão, eu sou responsável. Se sou desgraçada, eu sou responsável. Se eu fecho os meus olhos, eu sou responsável. Eu sou livre.".

A atriz Patusca disse um trecho do poema de Florbela Espanca de que se lembrara, chamado "Amar!". Esses dois textos fez o encenador lembra-se da frase que já estava no roteiro de ações e foi o texto que ficou definitivamente.

\section{g) Foco}

Uma das indicações que Fabiano deu para a Patusca foi para que a atriz desse espaço para o movimento, ou seja, dança-lo, deixa-lo crescer. Sem a preocupação com o tempo que essa ação levasse, pois nós tínhamos em cena dois focos. Patusca até pergunta se não perderíamos a sujeira do bastidor. O encenador diz que isso também está presente na figura da Christiane, que traz esse signo mórbido, a morte. Assim, o foco também se desloca em cena.

\footnotetext{
33 Trecho de diálogo retirado do filme Viver a Vida (1962), de Jean-Luc Godard, dito por Nana (Anna Karina), em uma cena em ela está se separando do marido. Os atores permanecem de costas para a câmera por toda a sequência.
} 
Há muitas maneiras de conduzir o olhar do espectador no teatro, assim como a câmera cinematográfica o faz. Podemos usar a luz, enquadramentos ou mesmo a ação de outros atores. Quando Christiane tira as luvas e as joga no chão, por mais que ela continue sua ação, ela transfere o foco para a atriz Patusca, quando esta as recolhe para por nas mãos.

\section{h) Constituição de imagens}

Fabiano retoma a ideia de que Christiane poderia ser uma projeção da figura da Patusca, por isso tirar o mesmo vestido que ela vai colocar, para começar a criar e estabelecer essas ligações entre as duas figuras. Pois ele reafirma que não seria o conflito que foi descrito no roteiro de ações que iria revelar muito sobre o discurso, além de não revelar a pesquisa.

Assim, ele propôs que fizéssemos um jogo de memória, um jogo de lapsos de tempo. Desenhar uma história que continua, mas que parece que ela está voltando para o começo. Para isso ele fez algumas alterações nas posições das imagens que as meninas estavam fazendo.

Começando pela imagem de costas da Christiane, que antes começava a cena pela penteadeira. Ele acredita que com o espelho, revelaria logo para o espectador o corte no rosto. Então, acha que seria melhor surpreender. A imagem de costas é muito emblemática, pois é de costas que nos é dado a conhecer Nana, em Viver a Vida. Ele pede para Chris, de costas, ser uma espécie de narradora, que dá início e conta a história, como faz Nana na conversa no café com o ex-marido.

Com essas operações genéticas, vimos que cada versão do exercício pode ser estudado de modo isolado para entender o resultado final. No teatro, isso se evidencia com o ensaio, o que Cecília Salles resume como uma estética do inacabado.

Quando o crítico estabelece as relações entre os documentos do processo e o que nele está contido, ele tenta refazer e compreender a rede criada pelo artista, 
através dos vestígios. Logo, ele pode se deparar com uma poética que aos poucos vai se revelando. Sobre Efêmea, essa poética é de poesia e plasticidade.

Poesia pela própria função poética da linguagem, que o uso de textospoemas reforça isso. $\mathrm{O}$ encenador sugeriu pesquisarmos poemas de Hilda Hilst, pois identificava com a força feminina. Assim chegamos a estes:

Gostaria de encontrar-te e falar das coisas que já estão perdidas./ Tuas mãos trementes se desmanchariam na sonoridade de meus ditos/ Faria dos teus olhos luz, da tua boca um eco/ Nos teus ouvidos eu falaria de amigos/ Quem sabe se amarias ouvir-me. ${ }^{34}$

Quando ela fala em encontrar-se com a pessoa, ela diz de um encontro que tanto pode ter a conotação do rendez-vous francês, quanto do encontro românico. Assim ela falaria das coisas deterministas. As metáforas dos olhos-luz e da bocaeco reforçam a força do homem, cujas mãos se retrairiam diante de qualquer atitude agressiva, como o corte fito em seu rosto. "Nos teus ouvidos eu falaria de amigos", mostra a concepção de 'amigos' no sentido usado por Ovídio, que nós estudávamos na época em $A$ arte de amar e também na relação amigável que ela espera, ou seja, na relação não agressiva. Depois, ela encerra com a dúvida, pois ainda assim ele é homem e sua postura determinista mostra que talvez seu desejo não se efetue.

Em: “Quando terra e flores eu sentir sobre o meu corpo/ Gostaria de ter ao meu lado tuas mãos e depois, colocar meus olhos dentro delas.", a inserção do texto na cena sugere um "eu lírico" que fala do momento da morte - com a imagem de terra e flores sobre seu corpo - e diz da vontade de cegueira, de não ter de enxergar seu rosto cortado. Ela repousa os olhos nas mãos dele, como uma oferta à mesma mão que cortou seu rosto. Em uma postura determinista de quem agrediu porque sofreu uma agressão, Christiane também corta o rosto de Patusca, usando o objeto batom com signo para navalha e a cor vermelha como signo de morte, sangue.

\footnotetext{
${ }^{34}$ Hilda Hilst in Baladas. Ed. Globo.
} 
Em um ato dúbio que denota tanto submissão quanto ingenuidade, Patusca toma a atitude de deitar-se no colo da outra atriz: o corte que em Christiane a força a um sorriso permanente, em Patusca coloca para fora uma canção. Ela canta 'La décadanse' de Serge Gainsbourg. Essa canção surgiu por improviso, o encenador pediu que ela cantasse algo que veio à sua cabeça e ela cantou essa música. Depois, nos pareceu que se relacionava com a postura decadentista de Toulouse, já que sua formação cultural se deu nos ambientes do Materisalimo Naturalista e do Extremismo Decadentista.

Outro exemplo de poema da Hilda Hilst que foi incorporado à cena:

Canção do mundo perdida na tua boca./Canção das mãos que ficaram na minha cabeça./ Eram tuas e pareciam asas./ Pareciam asa que há muito quisessem repousar./ Canção indefinida feita na solidão de todos os solitários./ Os homens de bem me perguntaram o que foi feito da vida./ Ela está parada./ Angustiadamente parada./ O que foi feito da ternura dos que amaram.../ Ficou na minha cabeça,/ mas tuas mãos que pareciam asas./ Que pareciam asas. ${ }^{35}$

A plasticidade veio pelo o que há de imagético tanto no cinema quanto na pintura, a construção das figuras, pelo gesto e pela ação. Nas palavras de Lautrec: "Apenas a figura existe. A paisagem é apenas um acessório.". Há plasticidade também no tempo cinematográfico presente nos filmes de Godard, com longos planos e que nos permite ver as imagens tanto em formação como em seu estado de móvel/estático/móvel.

Para a apresentação do exercício Efêmea no exame de Qualificação, o encenador reforçou o prolongamento do tempo para realizar a constituição das imagens. No vídeo 'Exame de Qualificação', podemos ver a imagem estática da Christiane com o vestido. Nesse momento, além de ter aparecido a figura masculina do ator Elton Santos que havia se juntado ao grupo, o encenador trouxe um texto que inicia a narrativa do sonho, uma descrição plástica:

Alheia a toda nudez, ela ouvia com a tristeza dos que trazem a alma vestida. Mas o som que vinha do piano soava como um canto de sereia. Sem entender a razão da animação, ia até à janela inspirar o perfume da noite. [...] Com o som

\footnotetext{
${ }^{35}$ Hilda Hilst in Baladas. Ed. Globo.
} 
do piano sussurrando-lhe ao ouvido, tomava uma taça de vinho. Sentia-se mais leve. $\mathrm{O}$ ar sorria à sua volta. [...] Mas se consolava de pensar que temos uma vida que é vivida e outra que é sonhada. Sabia que o nada que era, era o tudo dela.

Seguindo os encontros, em 16 de Setembro nós tivemos um ensaio. Ao final, nós tiramos um momento para analisarmos nossas cenas, em relação ao material que tínhamos estudados. Para tal, selecionei algumas pinturas de Toulouse-Lautrec e agrupei de acordo com os temas: a) Antes e Depois - onde vemos rascunhos de telas e as telas finais -; b) Arrumar-se - em que as modelos mostram esse momento do bastidor —; c) Cabaré; d) Juntas — onde há sempre duas mulheres juntas -; e) Toalete. As imagens podem ser vistas nos

\section{Anexos.}

As atrizes e o encenador fizeram muitos comentários, transcrevo-os aqui de acordo com o tema:

a) Sobre as telas de Juntas:

Eu acredito que aqui (nas pinturas) tem uma interação. Mesmo quando ela chega perto e eu deito a cabeça no colo dela, eu ainda sinto que elas não estão juntas. Eu ainda fico sentindo que são duas pessoas separadas. O próprio canto, e o choro... ainda assim, não é uma interação. Elas ainda nem se conhecem. É algo que tem nessas figuras e que não tem na gente. (PATUSCA)

b) Sobre as cores, os elementos de cena, e os estilo do pintor:

\footnotetext{
"Uma coisa que me chama a atenção é que sempre tem esse sofá. Ele aparece em vários. E essa cor. $\mathrm{O}$ que me chama atenção no Toulouse são as cores. Eu acho que esse ai é um grande signo que gente pode trazer dele para cá, que a gente não pode perder. Não é nem só a questão de roupa... Ao mesmo tempo em que tem muita cor, é muito escuro." (CHRISTIANE)

“É o submundo. Existe uma questão do ‘sujo'." (PATUSCA)

“Sim, é sujo, mas até o traço dele não tem aquela preocupação. [...] Essa preocupação do Impressionismo, ele foge. E ele trabalha muito com as sombras." (CHRISTIANE)

“É tudo ao mesmo tempo forte e fugidio." (PATUSCA)
} 
c) Sobre as mulheres retratadas:

“É porque ele não tinha a preocupação do traço perfeito. A coisa que me surpreendeu muito foi saber que as mulheres do Moulin Rouge não eram loiras. E ele coloca todas de cabelo loiro na pintura e ele as deixa mais bonitas do que elas eram." (CHRISTIANE)

“Elas eram muito engraçadas, não eram bonitas." (FABIANO)

"Mesmo as imagens de mulheres 'rechonchudinhas'. Na verdade, elas eram mais. Ainda assim, é idealizado." (PATUSCA)

d) Sobre as telas de Antes e Depois:

"O Toulouse tem muitos estudos que ficaram mais conhecidos que as pinturas. O que é o estudo para as Artes Plásticas? O que é esse momento anterior do momento acabado? E o que seria isso na cena? Eu vejo muitas nuances entre essa ação mesmo em qualidade e a ação final." (BRENDA)

“Esse aqui está muito mais sensual (refere-se á figura--). Parece que no estudo ele estava deixando essa figura idealizada. Quando eu estava aprendendo desenho, uma coisa que todo mundo ficava em cima, principalmente ao desenhar o olho, era: 'Não idealiza! Por que esse olho não existe. Ninguém tem esse olho.' No trabalho final, fica algo mais próximo, quando se estuda desenho realista. E daí dá para ver as diferenças como é mais idealizado." (CHRISTIANE)

“Está vendo como essa imagem é boa para você? (refere-se à figura--) Quando você coloca a perna, porque é muito bonito." (FABIANO)

"Acho que através dessas imagens a gente pode buscar uma precisão, uma limpeza dos gestos. E pode até trabalhar onde essa imagem ainda não está." (BRENDA)

"Ali, no trabalho final, parece que tem muito mais cuidado uma aproximação que aqui não me passa. (refere-se à figura --) Aqui me passa mais uma distância" (CHRISTIANE)

"Eu nos vejo assim (refere-se ao antes da figura--), mesmo próximas, sempre distantes." (PATUSCA) 
e) Sobre as ações:

"Eu tinha reparado que ela se olhava no espelho. Naquelas imagens do livro, eu não reparava. Que interessante isso Chris. Porque a leitura com a qual a gente pode brincar quando você está vindo, como se antes ela tivesse olhado no espelho, por exemplo, ela tirou a roupa e caminhou para lá." (FABIANO)

“É incrível que quando eu estou fazendo, eu não sei você, mas eu não estou pensando nisso. Eu estou fazendo. Eu estou sentindo, mas eu não parei. Eu conheço todas essas obras, pois eu estudei bastante ele. Mas em nenhum momento eu estou refletindo que estou fazendo essas imagens. Eu nem me lembrava que estou fazendo essa aqui. (aponta para a figura 20)". (PATUSCA)

"Quando eu falo em fluxo, é disso que estou falando. Quando eu estou pedindo as coisas, por exemplo: 'dá um depoimento, começa a cantar uma música alta' porque a cena está ali, está pedindo. [...] Agora vocês imaginem uma coisa: Isso é um acontecimento, ele viu e ele pintou. Há vida, ele retratou ali, uma época, uma história e uma vida. E uma ação. Então, gente, eu acredito nisso. Não é possível... É claro que a gente vai chegar a imagens como essas sem antes ter se dado conta. Porque é a ação que leva. É por isso que eu digo: 'qual a condição dessa mulher?'. E quando eu pedi para ela (Christiane) falar um depoimento, não é para aquele depoimento ficasse na cena - até me surpreendi com o que ela falou - mas isso gerou um estado nela, quando ela contou essa história que é dela, e é isso que vai interessar para a cena, que ela encontre esse estado, daí a gente pega um texto e coloca. Algo que tenha mais a ver com o contexto." (FABIANO)

"Eu pensava que depois que o espetáculo estivesse pronto, é que a gente fosse fazer. Mas não, já está tudo. Todas essas cenas." (PATUSCA)

“Mas isso foi porque quando a Brenda começou o processo, ela dizia: "Está aqui essa imagem, agora faça essa imagem." (CHRISTIANE)

'Mas comigo foi diferente, eu peguei em andamento. Eu não tirei daqui, mas ao mesmo tempo tirei.' (PATUSCA)

f) Sobre outros procedimentos que podem ser usados:

Eu irei pedir uma tarefa, tragam uma foto de vocês. Que seja alguma foto que remeta à mesma reflexão de quando você olha para um quadro. Uma foto que tenha uma história. (FABIANO) 
Entre 19 e 25 de Setembro de 2011, nós participamos da Mostra de Recortes Espetaculares do CEPECA, no CAC-USP36. Nessa ocasião, nós abrimos ao público nosso projeto de encenação que estava em andamento para compartilhar com os interessados em pesquisa em Artes Cênicas. Nosso intuito era debater sobre os conceitos que estavam sendo pesquisados, trocar informações e experiências com outros pesquisATORES ${ }^{37}$ e ouvir dos espectadores se a forma com que estávamos fazendo o nosso Teatro Intersemiótico trazia mesmo uma qualidade diferente para a experiência estética cênica.

Após a apresentação, o debate foi aberto e nós tivemos opiniões bem interessantes. Uma das opiniões que ficou mais evidente tinha a ver com a construção das figuras. Falas como:

Tive a sensação de que uma incorporava mais uma ideia da mulher em Toulouse-Lautrec e a outra seria uma mulher mais 'Godard'. [...] Na criação de imagens, tem imagens que estão dadas, mas para mim elas não se constituem, exatamente. Às vezes eu sinto falta de que cada imagem... No começo tinha um pouco mais, quando ela começa fumando - que se tem um tempo de ver que constituiu uma imagem, que não é estática como um quadro, mas é uma imagem que está dada - depois vai tendo uma sucessão de imagens que é menos 'limpa', como imagens que se compreende e lê. Outra coisa é que, para mim, enquanto cena eu não entendo qual é a relação, qual a situação que está dada. [...] Para mim ficou como se fossem as imagens separadas, duas referências que dialogam, mas enquanto relação, em cena, ficou ainda temática. (ALUNA DE GRADUAÇÃO EM ARTES CÊNICAS, DO CAC, 2011)

Essa fala representa bem o momento que estávamos com a pesquisa que era a construção dessas imagens e também a investigação sobre a relação entre elas. Não foi algo que ficou propriamente dito, nos ensaios. Até porque o objetivo era mesmo fazer um jogo entre as referências e não exatamente criar uma única situação dramática evidente.

No nível intersemiótico da apropriação, cada figura incorpora um conflito do autor com a linguagem. Ou seja, a figura de Christiane, reconhecidamente como uma mulher em Godard, pela aluna, é a tradução da

\footnotetext{
36 Ver flyer em Anexos.

${ }^{37} \mathrm{O}$ termo surgiu nas reuniões do CEPECA para designar aqueles atores que conduzem uma pesquisa sobre seus processos criativos. Hoje o termo dá nome ao periódico eletrônico do grupo. Ver: http://www.usp.br/pesquisator/
} 
construção do feminino em seus filmes, acrescida de outros anteparos e estímulos que a atriz buscou, como a referência da Mulher que ri. O mesmo acontece com Patusca em Toulouse-Lautrec.

Patusca comenta sobre o tempo e a construção das imagens, comentado pela aluna:

Eu acho que esse espetáculo não é para ser feito nesse 'frenesi'. Só teve duas partes que eu gostei, que foi a parte que eu estou sentada fumando quando ela vai se cortar. Eu acho aquela cena linda. Eu acho que ela tem que ser mais limpa. E a parte que a gente faz o toque. São momentos que têm que ser vividos. As pessoas sentem falta das telas mesmo, depois isso foi comentado. $\mathrm{O}$ ato de colocar a meia. [...] Acho que entra a culpa também da atriz que está ansiosa, pois na hora eu fico ansiosa... Mas não teve o congelamento. (PATUSCA)

Christiane concorda: “Não é ser rápido, ser lento, ou congelar. É pegar um ritmo. De ter algo mais pausado, o cigarro, o olhar." E Fabiano responde:

Tem outras informações, mas tem uma informação primeira que está sendo dita agora. Eu concordo. [...] Você está falando de coisa que já está na cena. Esse tempo de colocar a meia. Se você não realiza esse tempo, a informação não é dada. Se o tempo da ação não é dado, você passa por cima das coisas. Para quem está ali para assistir: 'Tem o Toulouse, tem o Godard, é temático.' Porque há o discurso, é isso que está faltando, e está na dramaturgia do ator. E é isso que estou tentando levantar aqui. Se você continuar levantando esse ponto, nós não vamos caminhar, não vamos sair do lugar. [...] Quando eu digo: 'conclui a ação', é isso que estou dizendo para você. Esteja no seu lugar. Tem coisas que se faz no ensaio e que na hora não se faz. [...] Eu não abro mão: Tem coisas que já estão presentes. Está na cena. E a essas coisas, tem que prestar atenção. [...] O fato de haver uma nova reformulação, até na própria forma que a pessoa se coloca, para mim já ouve transformação. A pergunta que fiz é: 'A partir do que ela falou, o que é que a gente percebe que na apresentação não aconteceu e o que acha que falta acontecer?' É disso que se trata, é um processo. Vamos identificar. Agora, então, como trabalhar na cena? (FABIANO)

A atriz então comenta que sente falta de coreografar algumas cenas, como no caso da dança. O encenador continua, esclarecendo que sua função é dar as indicações, a partir do que o ator propõe, e que essa mudança de postura do ator precisaria se transformar, minimamente que fosse.

Por exemplo: Quando eu digo 'ela tirou a luva, jogou em você, ela deu o texto'. Quando ela termina de dar o texto, se essa ação não aconteceu, tem uma informação que está na ação que é a abertura para que o público leia que não 
aconteceu. Isso não aconteceu, não houve a leitura, por mais que tenha sido executado. O que é que tem que acontecer? Abrir a percepção. Porque vocês não se vêm. Mas as atrizes estão jogando. [...] Nesse momento, não dá para imaginar a ação do outro, pois cada um tem um jeito de se colocar na cena. E isso enfatiza o que eu iria dizer em seguida: Por que tem que se perceber? Porque está diante do público, você está na cena, você tem que ser autônomo no que você está fazendo. Não pode ter expectativa, querer fazer uma ideia de alguma coisa. É presente! O que eu fico imaginando que o que aconteceu, até mesmo porque eu sou ator também, é o seguinte: não foi até o final, não conclui a ação, não se percebe, não percebe o outro na cena porque está esperando de fora alguma coisa. E não é de fora. O público não está no centro. O diretor não está no centro. Quem está no centro é o ator. $\mathrm{O}$ ator direciona o olhar. $\mathrm{O}$ ator gera a leitura. [...] Na realização, quando você está na cena, você não conclui. O que você tem que estar atenta para acontecer, não acontece porque, de antemão, você está preocupada do que o outro já está achando. Você está esperando lá na frente o que vai ser. E não, é aqui! [...] A gente direciona olhar e a sensação do público, o que você sentir na hora, o público sabe. Não esconde. [...] Essa meia que é colocada, quando eu digo que é uma dança, que tem um tempo para ser feito, eu estou pensando na imagem. Se essa meia é cotidiana, ela não tem significado. Isso tem uma relação com o tempo. O colocar a meia é signo. Ela tem um tempo para acontecer. Isso que acabou de acontecer em um tempo, daqui há pouco, para a próxima ação, tem que modificar, não pode acontecer, e não deve, acontecer no mesmo tempo. (FABIANO)

\section{E conclui, sobre nosso processo criativo:}

A gente vai ter que buscar estratégias para o que a gente está construindo, porque eu vou dizer de novo, é um tempo que não dá. É a primeira vez que faço isso. Em meus processos, a primeira coisa que eu vou é para o corpo. Mas para esse tempo, não dá, e daí é como você vai proceder. É o procedimento. É muito difícil o que estamos fazendo. (FABIANO)

\section{Para Christiane, o jogo já está explícito pelo espelhamento, mas ainda}

assim, as vezes temos algumas falhas de execução que comprometem a leitura, dando a impressão que o melhor acontece nos ensaios, no processo em si.

Por exemplo, se tem esse espelhamento, em algumas partes, principalmente no começo, ela está nítida. A partir do momento em que a peça começa a ficar um pouco mais dinâmica, se perde esse espelhamento. E daí, essa relação que antes era esse duplo, acho que ele deixou de existir. Uma das minhas preocupações quando eu deixei de sair de trás da penteadeira e comecei a caminhar foi ver que a Patusca estava desse lado... Daí vendo, eu vi que não é só nesse momento, a partir de um determinado ponto, se perde. Porque antes existe uma dinâmica, que constitui as imagens sem ser uma pausa. Tem as imagens e depois essas imagens vão se perdendo. Mas não é nem por uma questão de porque está rápido ou porque não tem pausa, talvez seja o que você falou, a gente ficou ansiosa mesmo. A partir do momento em que eu comecei a girar a Patusca e as coisas começaram a dar errado. Eu senti, em mim, que aconteceu uma transformação. De sair mesmo. Eu estava em uma concentração, com 
ritmo, e aquilo lá me quebrou. A peruca, as rodinhas travando, o batom caiu... $\mathrm{Eu}$ me desconcentrei geral. Se fosse um ensaio, eu iria dizer: 'para, calma, vamos começar de novo'. E dalí começou a se perder.... E perdeu o espelhamento. A partir do corte, teoricamente, devia haver o espelhamento de novo [...] Eu não gostei da minha voz. Eu perdi a intenção das coisas que você tinha me falado. [...] Eu não sabia nem o que eu estava fazendo mais. Ouvindoa falar, pensando nisso. Eu acho que a gente consegue resolver com os espelhos. Acho que isso é uma boa forma de resolver essa relação delas. Quer dizer, a não-relação delas diretamente. Mas a partir do momento... se vai ter esse impacto, e esse espelhamento vai quebrar esse momento. Daí, sim, tem que surgir essa relação que não existe ainda. (CHRISTIANE)

\section{O encenador comenta sobre a relação entre as duas figuras e os ajustes}

\section{que precisavam ser feitos:}

Tem que ocorrer uma mudança, não só quando é uma outra relação, que é quando você tem o primeiro contato com ela, mas antes disso: quando vocês estão juntas no meio. Já é uma outra relação, porque é o centro da cena, onde vocês estão juntas, onde você se encontram. E o que está faltando... Eu estou pensando assim: Em tudo o que eu estou propondo para a cena, tem uma suspensão. Daí eu comecei a pensar se essa suspensão não era algo que ia prejudicar o trabalho, que esteja sempre em suspensão. Mas agora eu penso que não. Que a suspensão não prejudica o trabalho. Essa suspensão, ela está a serviço do discurso, daquilo que vai ser dito, entendeu? Isso já me responde e já me tranquilizo. Agora o que falta acontecer é uma transformação de uma coisa para outra. Vocês estão indo de uma coisa para a outra sem o corpo se transformar. Mesmo a tua figura que está no futuro, e na cena, a nossa tentativa é dar uma leitura dessa trajetória da Patusca chegar à decadência em que essa outra se encontra, nesse limite, nesse limiar que essa figura que está no futuro está. Ainda assim, tem uma transformação que acontece porque é uma trajetória que está na cena da tua figura, e ela tem que acontecer. Lembra que eu falei: 'Chris, você começou em um ritmo e você percebeu, que você está chegando em outro, no final da cena?' É isso que tem que acontecer, porque é uma transformação que pode ser interessante. Só de ritmo... Ela começar a ganhar um movimento físico, independente do que seja, que tem um outro tempo, que está mais próximo do que você estava realizando no começo. E você, num movimento que está ligado, próximo do que ela estava fazendo. Essa é uma transformação muito significante e pode ser qualquer ação, não importa a ação. Mas o tempo dela é significante para a cena, essa alteração. Porque não tem uma narrativa, não é uma lógica em que eu tenha uma história dada de início, meio e fim. Tem o início, meio e fim de um trabalho, de um espetáculo, de uma concepção. Mas os elementos que aparecem, que constituem a cena, a cada momento em que ele é usando - tudo: batom, cigarro, indo para a janela, indo para o divã, toda vez que esse divã é girado ele não é o mesmo, não pode ser a mesma coisa, ainda que o fim dele fosse utilizado para a mesma coisa. E se mudou, então, mudou o significado desse objeto na cena. Se eu digo que esse batom é uma navalha, em determinado momento, você tem que agir com ele... porque isso é tradução. Aí a gente entra no mérito do signo, do objeto como um signo. Ele tem que ser usado como uma navalha. Como eu pego uma navalha? Para que fim esse objeto é usado? De intenção. Então, a intenção é o que vai ajudar a modificar esse físico, esse corpo, as intenções, o ritmo. (FABIANO) 
Com relação à tradução dos filmes, está a atmosfera criada em cena, já em Godard é comum notarmos que a câmera testemunha os fatos, rodeia os personagens, mostra-os mas ela não os explica, ela não conclui, porque não está conduzida pelo escritor ou pelo pensador: é cinema.

$\mathrm{O}$ tratamento conferido ao modo de atuação dos interpretes. Rompe-se com o analítico-dedutivo, com o compor um tipo de normas prefixadas. Nesse ponto, a autonomia da sétima arte poucas vezes se manifestou com tanto vigo. [...] Os atores não estão para representar, mas representam para estar. Daí a aferição não casual de um ser pelo estar - a técnica do comportamento. Os personagens se dão a conhecer através do filme e não em virtude de rótulo generalizante para um determinado conteúdo abstrato - não há conceito anterior. O personagem não evolui classicamente - seus atos e palavras são, à primeira vista, contraditórios, porque não se definem em termos anedóticos, de narração. Um jogo de contrastes e conflitos forjando um realismo pela ambiguidade. (GRÜNEWALD, p. 73)

O autor ainda acrescentar que o comportamento predominantemente de reações é mais característico do teatro e que o cinema propõe um comportamento predominantemente de ação. Essa é a atmosfera que tentamos imprimir na tradução dos filmes.

\subsubsection{DRAMATURGIA TEXTUAL}

Após o exame de Qualificação, nós decidimos seguir as indicações feitas pela banca com relação ao exercício cênico. Na ocasião foi mencionado que a situação dramática e o discurso poderiam estar mais claros. Isso nos incentivou a produzir uma dramaturgia textual para que o discurso fosse explicitado também pela palavra. Dessa forma, após uma breve pausa dos encontros, a atriz e também dramaturga Patusca, em três dias, escreveu o texto: ...E Fêmea ${ }^{38}$, que resultou em uma segunda montagem.

É sobre esse segundo exercício cênico que disserto nesse capítulo, bem como sobre os processos de dramaturgia do ator vividos pela Patusca e também por mim, Brenda de Oliveira, que participei nessa etapa como atriz, para substituir Christiane Martins que precisou afastar-se para iniciar a escrita se sua dissertação de mestrado, sob a orientação do $\operatorname{Prof}^{\circ} \operatorname{Dr}^{\circ}$ Felisberto Sabino.

\footnotetext{
${ }^{38} \mathrm{O}$ texto completo está em Anexos.
} 
É importante dizer que nessa etapa além de terem sido traduzidas exclusivamente as pinturas de Toulouse-Lautrec sobre as Casas de Tolerância francesas e os filmes Viver a Vida e Uma Mulher é Uma Mulher do Godard, nós acrescentamos o filme L'Apollonide - Souvenirs de la maison close como estímulo e influência direta na construção do discurso.

Para as pinturas das Casas de Tolerância, também conhecidas como maison close, uma distinção histórica deve ser feita. Há dois tipos de mulheres retradas: as que pertenciam à maison, essas eram prostitutas registradas (soumises) e as que passaram a andar pelas ruas, (insoumises).

Não se sabe precisar quantas pinturas de bordel foram feitas pelo autor e nem o período em que elas foram realizadas. Alguns autores sugerem como quantidade certa de quarenta imagens, e em relação ao tempo, algo em torno entre 1892 e 1895, porém, o que de fato caracterizaria uma maion close ainda permanece ambíguo.

É certo que os locais mais frequentados pelo pintor ficavam no quartier das ruas d'Ambroise e des Moulin próximo ao Opéra e à Bibliothèque Nationale. Entretanto, é incerto que ele tenha trabalhado em motivos desses estabelecimentos seja em uma representação específica ou generalizada de seus interiores. Também não é possível dizer quantas dessas imagens foram exibidas. Sabe-se que em 1896 houve uma one-man-show exibition com algumas pinturas, mas não há catálogo ou lista deste período que tenha restado.

Quanto às mulheres, tudo dependia do isolamento das prostitutas. $\mathrm{Na}$ época, um sistema foi operado, controlado pela police de moeurs, que permitiu duas formais legais de prostituição. A mais importante dessas foi a maison de tolèrance ou maiosn close, nas quais prostitutas soumises poderiam fazer seu comércio em particular e sob a supervisão imediata de uma madame. Um número limitado de prostitutas era permitido operar independentemente, em carte. As inspeções médicas eram regulares.

Por volta das décadas de 1870 e 1880 era evidente que a burocracia não estava apta para refrear a disseminação da prostituição. O debate público proliferava-se, geralmente concordando que a força por detrás desse perigoso 
crescimento fosse econômica; a mulher proletária, já julgada a ser inclinada à prostituição pela moral inferior de sua classe, era, mesmo que temporariamente, forçada pela necessidade financeira a andar nas ruas - essas eram as insoumises.

\subsubsection{Patusca}

\section{a) PROCEIMENTO 1: Construção de Margot}

Para a construção da personagem Margot, a atriz apoiou-se nas releituras de textos literários das escolas Naturalista e Realista. Dentre esses, ela cita contos de Émile Zola, autores brasileiros e o texto Diário de um Ladrão, de Jean Genet - autobiografia do autor parisiense, lançada em 1949, a qual descreve o sua trajetória desde a infância, criado por pais adotivos, até os primeiros roubos e sua iniciação homoerótica - , livro descrita pela atriz como vil.

Sobre este livro, a atriz diz que cabe um simples paralelo entre o submundo francês, embora ela afirme que é preciso cautela nas comparações já que, de certa forma, o autor mostra um gosto pelo contexto em que está inserido, afirmando que sua condição não se trata apenas de necessidade. Isso se contrapõe ao ponto de vista feminino lido por ela nos textos plásticos e fílmicos, onde estar naquela situação é historicamente irrefutável para as mulheres, cuja saída é encontrar naquele contexto algo que o torne mesmo ruim.

Ainda sobre Margot a atriz afirma que uma das coisas confortáveis nesse processo de construção da personagem foi o fato de ela mesmo ter escrito a dramaturgia. Isso simplificou a criação do papel já que ela sente que não houve diferença entre o que ela escreveu e o que já estava sentindo sobre o feminino ao longo do processo: “Eu coloquei no papel o que eu já sentia no processo, o que eu achava desde o início. O que me trouxe a dramaturgia foi a condição do olhar.", segue explicando: "Quando eu olho para aquela tela em que tem uma mulher pondo a liga ${ }^{39}$ já imagino que lá embaixo tem gente, já tem musica. Já

\footnotetext{
${ }^{39}$ Refere-se ao acessório usado junto à meia
} 
passa um filme na cabeça. É uma narrativa por imagem.", diz ela referindo-se à narrativa do cinema e das telas.

Sobre o texto, Patusca afirma que sempre teve receio quanto às referências estudadas, como, por exemplo, os textos naturalistas que ela releu, pois sabia se tratar do olhar masculino para a condição feminina. Essa foi uma de suas preocupações estéticas ao escrever ...E fêmea, já que nele haviam duas mulheres que falavam de si. Para ela era imprescindível passar do analisar, para o viver.

Segundo ela, a diferença está em: “O homem descreve o frio, a mulher sente o frio. $\mathrm{O}$ homem descreve a fome, a mulher sente a fome. $\mathrm{O}$ homem apenas escreve 'a cerca de', a mulher vive o peso da consciência do seu próprio corpo". Também em seu processo, Patusca leu sobre a biografia romanceada de Toulouse-Lautrec, onde destaca frases que mostram o olhar do autor sobre as a mulheres: "Como é bela! Parece uma prostituta." 40 - ele diz sobre uma lavadeira que passa na rua. Esse é um dos exemplos de seu interesse pelo momento histórico retratado no texto, com as divisões de classe, a exploração do trabalho feminino e infantil.

Tanto a retomada do processo quanto a inversão do olhar homemmulher para mulher-mulher podem ser vistas pelos vestígios deixados ao longo do trabalho. Quando a atriz ainda na época do primeiro exercício cênico escreve um texto para a tela Rousse (La Toilette), de 1889 ela já aponta para o que veríamos em ...E fêmea.

Segundo alguns autores, o Naturalismo estava frequentemente associado a um ponto de vista 'do alto', dando ao espectador uma dominação implícita sobre a modelo que poderia ser interpretada mais adiante como uma relação entre o cliente masculino e a prostituta submissa. Alguns críticos dizem que ele pintou a modelo com o ponto de vista de um cliente que a observa no seu momento de intimidade e higiene, parte do ritual de uma prostituta. Entretanto, há evidências de que seja apenas um estudo de estúdio, pois embora Lautrec

${ }^{40}$ Toulouse-Lautrec (SAGNE, Jean). Trad. de Antônio Carlos Viana, Porto Alegre: L\&PM, 1990. 
tenha se preocupado em criar uma ambientação de tolete, pois colocou uma bacia, uma tina e toalhas, ele preservou a figura de uma cadeira muito sofisticada, que raramente estaria no quarto de uma fille. (Figura 30)

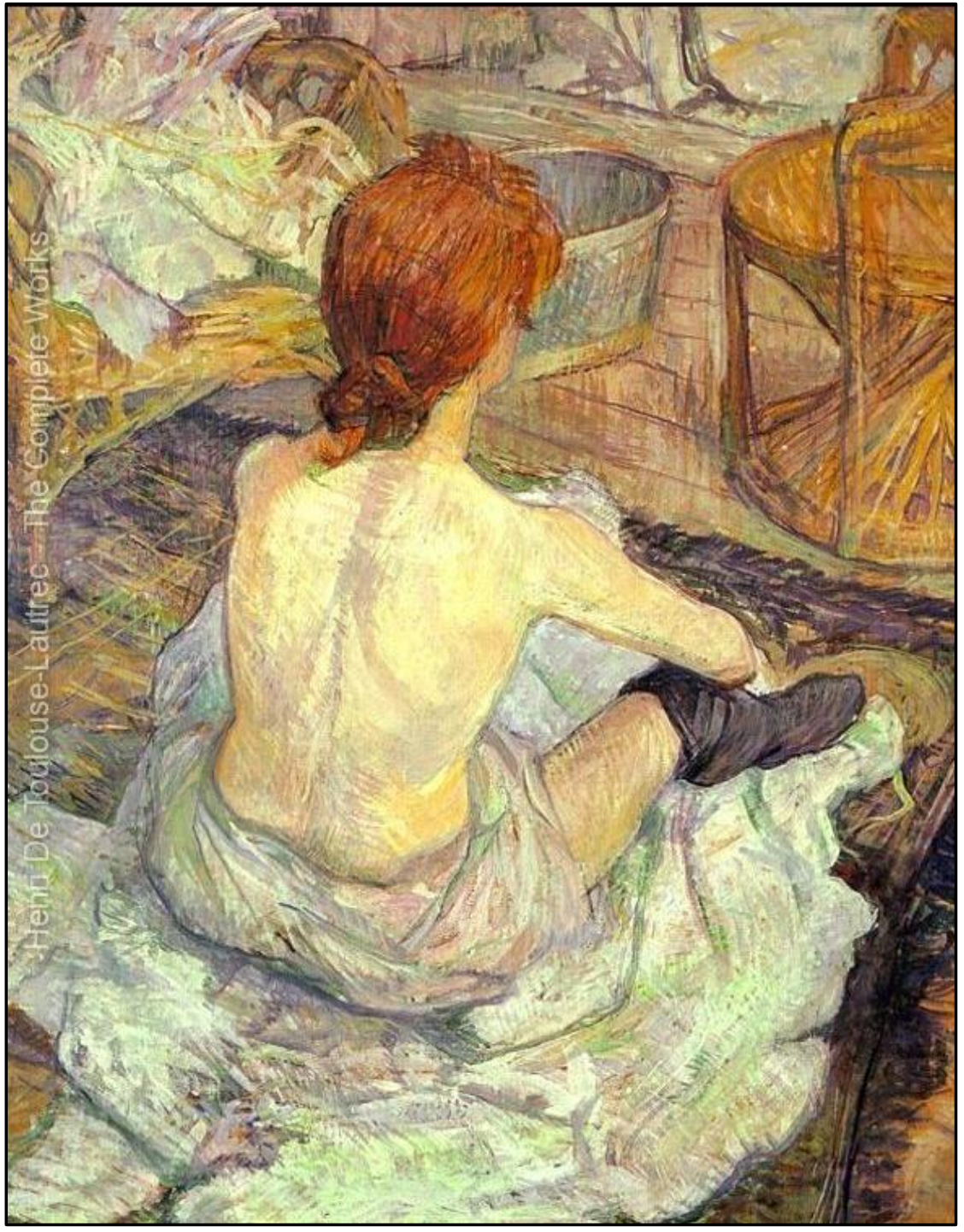

Figura 30: Rousse (La Toilette) - TOULOUSE-LAUTREC (Fonte: www.toulouse-lautrec-foundation.org em 13, set de 2011)

Ainda assim, está implícita a posição de dominação do olhar masculino tanto como cliente quanto como pintor. O que é reelaborado no texto da atriz em que traz o ponto de vista todo para a mulher, quando diz:

Ela queria a si, e por isso passou a compreender o que tanto os olhos dele a cercavam. Era linda, era plena, sem medidas de comparação porque não havia com o que comparar, única. E sua estima por si foi de um arrebatamento tão absurdo que chegou a desdenhá-lo no seu íntimo, não o desejava mais, desejava a si, era a si que queria, se agradar, se cortejar, se tocar. ${ }^{41}$

${ }^{41}$ Trecho do texto escrito pela atriz. Ver esse e outros textos completos em Anexos 
Algumas distinções no trabalho de Lautrec persistem. A sua representação de mulheres, geralmente o fazem retrata-las nos seus mundos interiores. As mulheres de sua família são retratadas tomando chá, tocando piano. Mesmo em suas representação de maison close, as prostitutas são vistas em atitudes consideradas femininas, ou seja, jogando cartas, cochichando em torno da mesa e não exatamente trabalhando, com um cliente, o que dá abertura para a tradução do discurso para o ponto de vista feminino já que o próprio Toulouse parece reconhecer que ele exista.

A representação masculina, por outro lado, é de homens do mundo, homens que pertencem ao mundo do lado de fora do bordel. Há uma justaposição na tipografia de Paris: proletárias de moral equívoca e baixa renda. Homens burgueses de sexualidade predatória, possíveis clientes. O vício está até em suas cores, uma coloração masculina, forte. A temperatura quente e a tonalidade ocre, empregadas nos interiores, não eram simplesmente uma mera tentativa de Lautrec em gravar as cores de uma sala, mas de aumentar a temperatura do espectador, implicitamente masculina. Talvez por isso o contraste das imagens de proletárias e bordes distanciar-se daquelas empregadas nas imagens de homens.

Há outra questão contraditória. É sabido que de fato Lautrec tinha sinceras amizades com mulheres de baixa classe. Algumas de suas pinturas de prostitutas dão a elas uma identidade distinta. Mas há, por exemplo, estudos em que mal se consegue distinguir a figura do ambiente, de forma a propor uma leitura de quase indistinção da mulher e da degradante função que ela exerce.

\section{b) PROCEDIMENTO 2: Concepção de figurino}

O interesse de patusca sempre esteve na concepção de um figurino que estivesse de acordo com o recorte histórico feito nessa dramaturgia textual, o final do séc. XIX. Assim, ela aliou algumas imagens históricas de sua própria 
pesquisa e descrições literárias ao figurino mostrado no filme L'Apollonide. As referências podem ser vistas em Anexos.

\subsubsection{Brenda de Oliveira}

\section{a) PROCEDIMENTO 1: Construção de Norah}

O que de principal posso destacar da construção da personagem Norah, tem a ver com a tradução e apropriação do discurso que identifiquei em certas telas do pintor francês e da interpretação de Anna Karina, nos filmes de Godard. Não busquei a mimese do gesto mas a identificação de um subtexto para dar à falas de Norah, na dramaturgia.

Poderia citar as telas: Gueule de bois (1887), Elles: Femme sur les dos Lassitude, Femme fumant une cigarette (1890), L'Inspection médicale: femme de maison blonde (1894), Femme rousse nue accroupie (1897) e as representações lésbicas do pintor em Le Deux Amies e Le sofá. Citando os filmes, interessou, sobretudo, transcriar os longos planos como os de Viver a Vida, e intercalar momentos de seriedade como momentos cômicos, como os quais a personagem Angela vive em Uma Mulher é Uma Mulher.

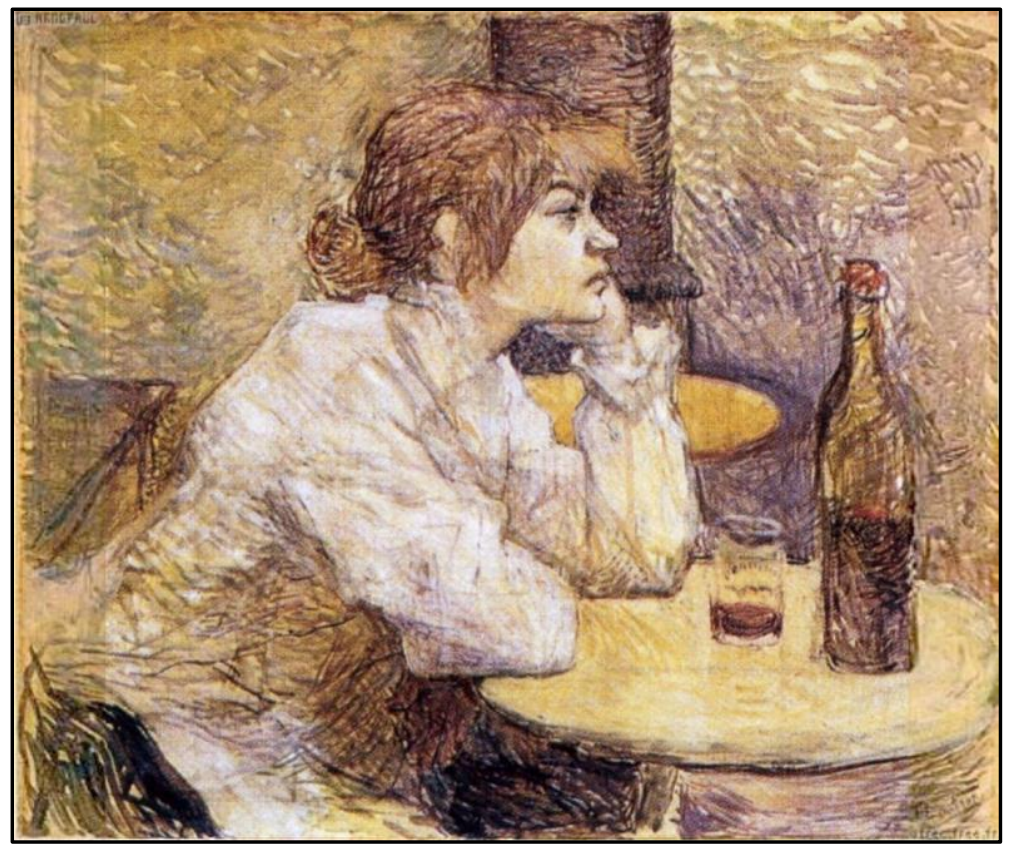

Figura 31: Gueule de bois, retrato de Suzanne Valadon - TOULOUSE-LAUTREC (Fonte: wikipedia.org - em 04, ago de 2012) 
Em Gueule de bois (Figura 31) busquei traduzi a feição morosa de Suzanne Valadon, retratada pelo pintor, pois identificava semelhança entre essa imagem e a espera de Norah nos bares, cafés e na rua por um cliente. Usei essa imagem para ilustrar o subtexto na cena de abertura da peça, já que a pintura mostra a modelo debruçada em frente ao seu coup de rouge. Esta é uma a mulher que representa um tipo social problemático e segundo estudiosos, o texto pode ser lido de várias formas: expondo a depravidade do proletariado, demonstrando uma provável prostituta, causando pena por uma mulher reduzida por circunstâncias de dominação. Gostaria de abrir a peça com esse discurso do ponto de vista masculino para poder ir revelando a personagem aos poucos.

Elles: Femme sur les dos - Lassitude está presente na cena entre Pierre e Norah. Essa tela é um estudo da litografia final. Da passagem de um para outro, ficaram o chapéu e o casaco, típicos das insoumise - a mulher que saia às ruas em busca de um cliente. O cansaço, o tédio e a fraqueza estão no discurso que a cena entre Norah e Pierre traz: 'contratada' para servir Pierre que mais uma vez demonstra seu comportamento excêntrico diante das mulheres. Dessa forma, Norah, que não sabe como agir, já que ele permanece apenas olhando-a, joga-se na cama, de pernas abertas para que ele a observe. A mão na cabeça me sugeriu a leitura de que essa cena pudesse expressar um exibicionismo. (Figura 32)

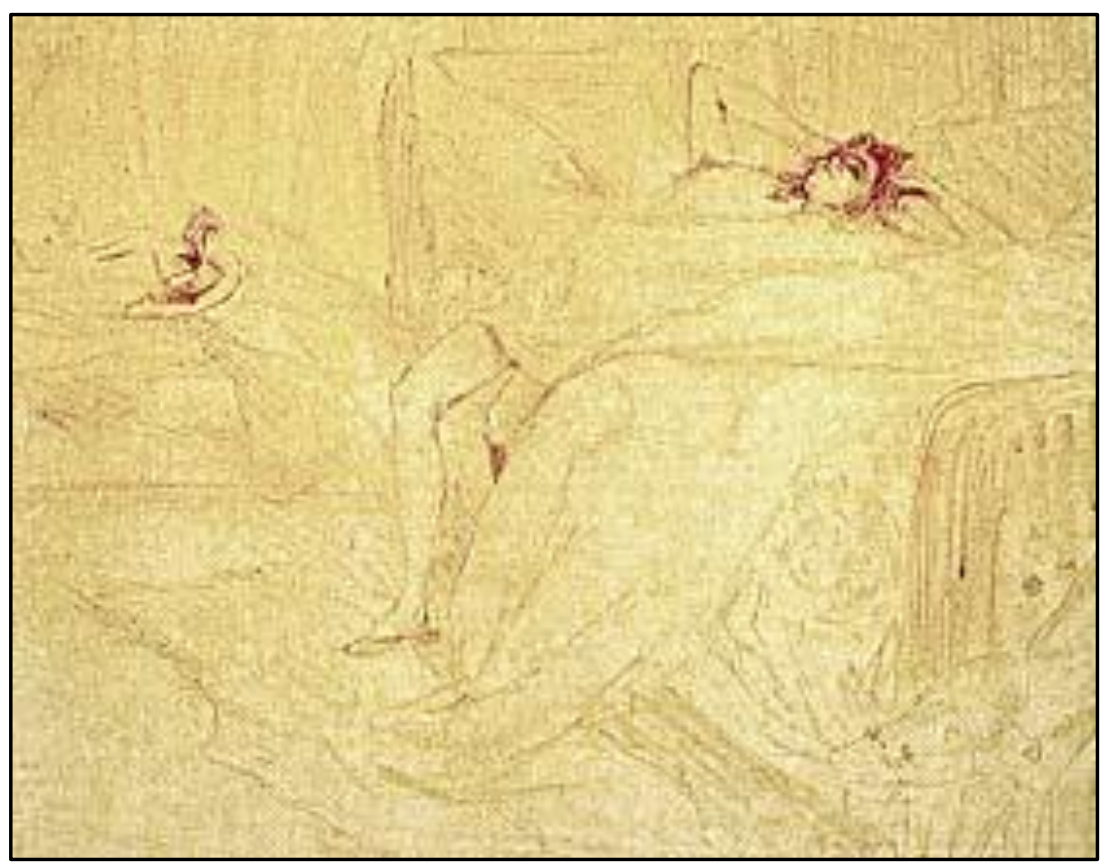

Figura 32: Elles: Femme sur les dos - Lassitude - TOULOUSE-LAUTREC (Fonte: kennethbehm.com em 04, ago de 2012) 
Em Femme fumant une cigarette, o mobiliário e o lavatório negam concerteza que seja uma cena de estúdio, configura, assim, uma imagem em uma instalação de uma jovem proletária, com sua blusa simples e penteado elaborado. Entretanto, a ambiguidade permanece por não sabermos se ela é uma prostituta, uma trabalhadora ou uma mulher de classe baixa operando entre as duas funções. É nessa indefinição que gostaria de estabelecer uma relação entre Margot e Norah, cujo passado não se conhece pelo texto, mas que pode ser construído pela genesis da personagem e estudo das relações.

Na cena II, Norah diz:

\begin{abstract}
Estou cansada. Estou que não suporto mais as privações, a falta, a impossibilidade. Ter de sair todas as noites para buscar quem me pague o jantar, ter de dormir entre tantos para me aplacar o frio. Me enoja a inspeção sanitária, ver aqueles homens de branco obrigando-me a deitar e a exibir-me a eles, com aqueles olhares gelados sempre à eminente possibilidade de estar ou não doente, desdita mais podre, diagnosticada por aqueles vermes de jaleco, igualmente podres, que tenho pra mim que os próprios colocam a doença em nós. E que fim mais repulsivo. Ter de ver outras sendo recolhidas por conta da moléstia. Tenho nojo delas, mas hoje são elas, amanhã poderei ser eu; eu doente com aquele cancro a me corroer inteira a começar pelas partes, me consumindo de febres e ulcerações pútridas, me decompondo o corpo ainda em vida, pulsando em mil agonias... (PATUSCA, p. 5)
\end{abstract}

Para criar o subtexto, utilizei o discurso histórico por trás da tela L'Inspection médicale: femme de maison blonde. Naquela época a estatização da inspeção média estava central no debate sobre prostituição. Entretanto, uma das coisas que se fala sobre eram as péssimas condições sanitárias da inspeção, o que leva Norah a acusar os médicos de colocarem as doenças nelas. (Figura 33)

Nas relações com os clientes e suas excentricidades, destaco a imagem Femme rousse nue accroupie, onde encontrei uma relação mimética e de analogia entre o contexto do quadro e a cena em que Norah volta para casa após ter dormido com 'o poeta'. O mimetismo está na própria pose da modelo, também descrita por Norah, já a analogia está na tradução da postura de Lautrec como pintor com a postura do poeta, como cliente. (Figura 34)

Segundo alguns autores, na época desta tela, Lautrec não estava pintando nada que o interessasse, mas forçou-se a pintar como exercício e um estágio importante pelo qual devia passar antes de retomar sua motivação 
artística. Neste quadro, a narrativa sexual é o menos importante, se levarmos em conta o contexto factual no qual a figura feminina está inserida.

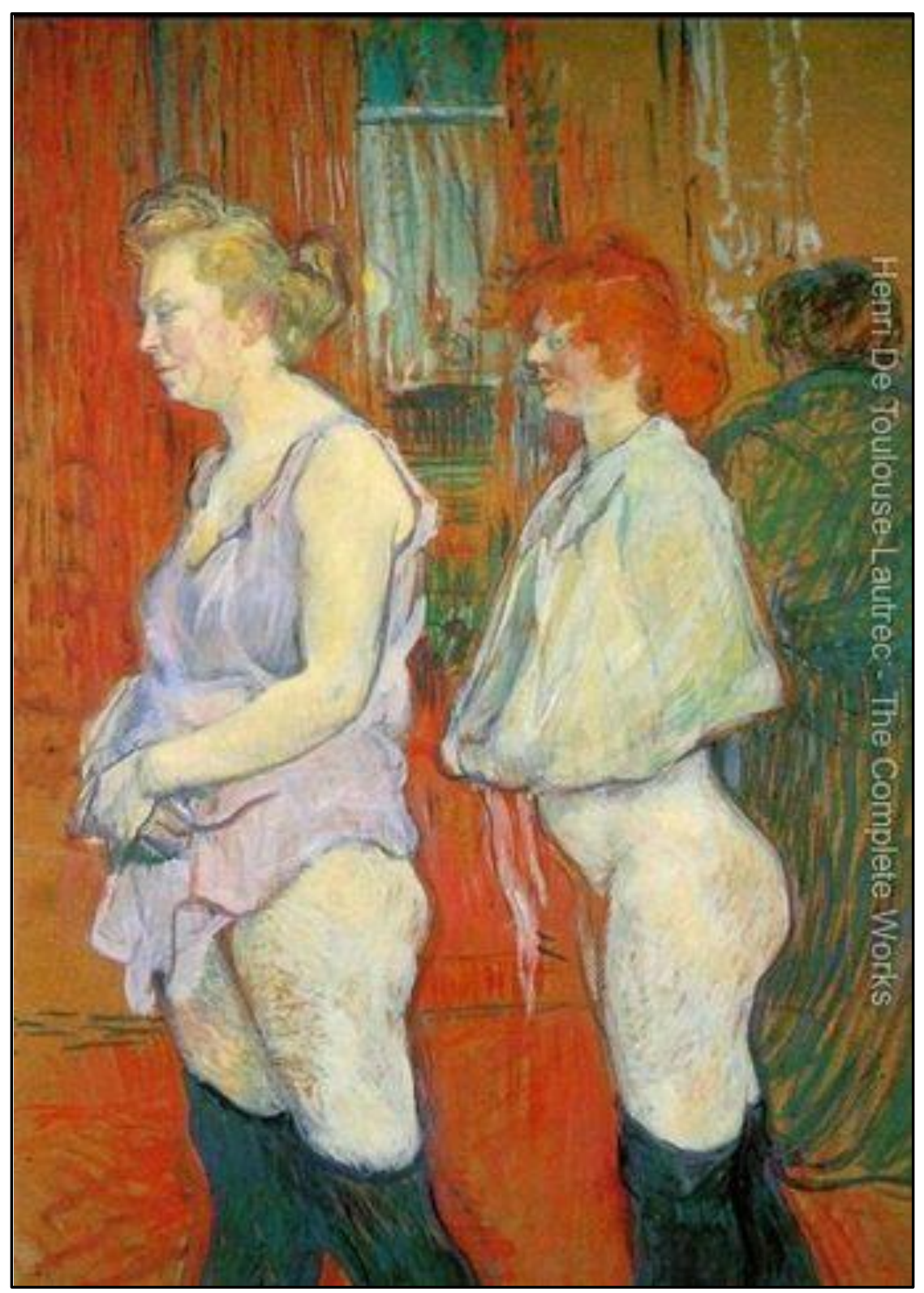

Figura 33: L'Inspection médicale: femme de maison blonde - TOULOUSE-LAUTREC (Fonte: www.toulouse-lautrec-foundation.org - em 13, set de 2011)

Nessa mesma época, Lautrec mudou-se para um novo estúdio na rua Frochot. Ele havia decorado o local com esteiras de palha, e sua presença ao fundo desta pintura sugere que ela tenha sido feita lá. Nela, aparece uma modelo que também aparece em outros estudos do pintor. No final de 1897, ele escreveu em uma carta: "uma modelo de confiança a qual eu finalmente fui sortudo o bastante para contratar. É duro voltar ao trabalho, e o que eu estou fazendo de lá para cá não me interessa muito. Mas é um estágio necessário.”. 
Há muitos discursos na tela, mas por se tratar apensa de um exercício, sem grande apelo narrativo, nós retiramos o discurso sobre a meta-pintura. A modelo que pousa incansavelmente para o pintor, que ao final do trabalho conclui não ter feito "nada que lhe interesse".

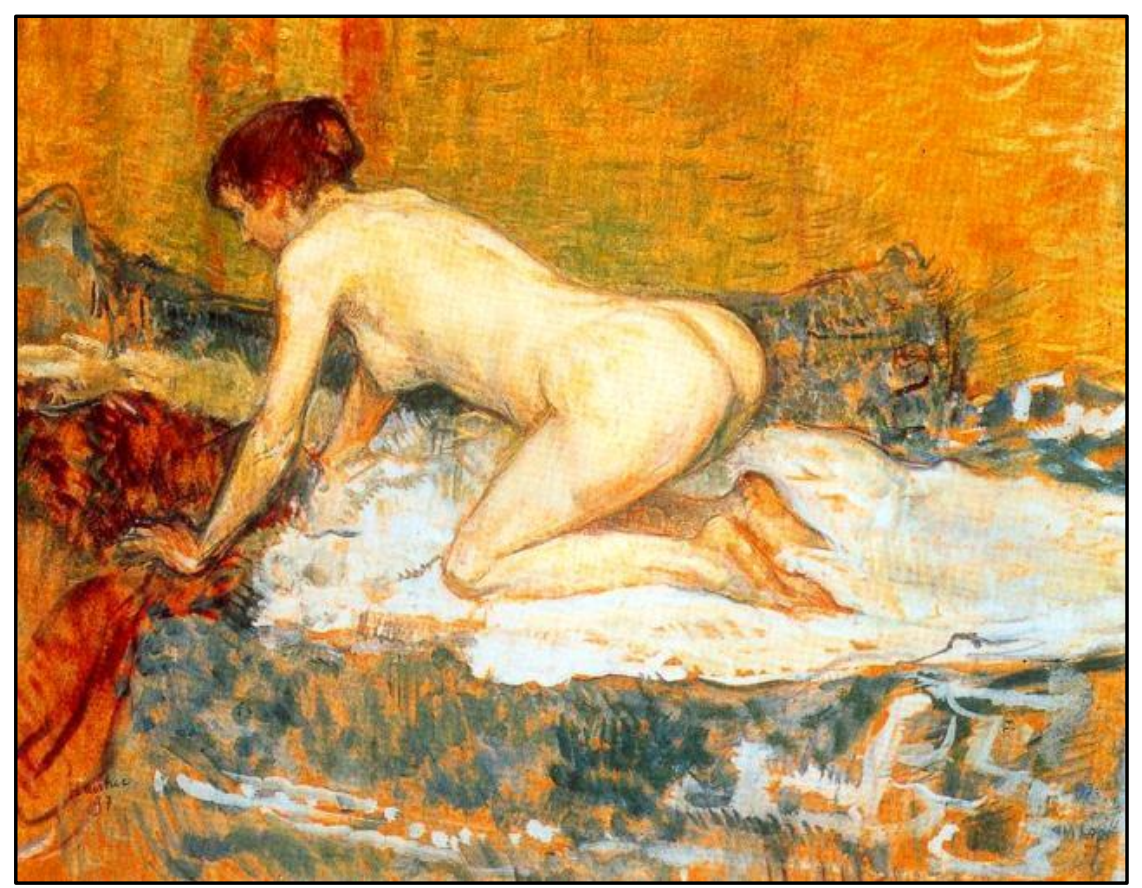

Figura 34: Femme rousse nue accroupie - TOULOUSE-LUTREC (Fonte: www.toulouse-lautrecfoundation.org - em 16, mar de 2012)

Obviamente, não estamos falando da posição pessoal de ToulouseLautrec em relação à modelo, até porque se trata explicitamente de uma relação profissional, ou seja, esta é a função da modelo tal qual da prostituta - como na cena em que Norah sai com o poeta, volta exausta dizendo que ele a pediu para declamar um poema por dezessete vezes enquanto eles transavam.

A posição rigidamente fixada da modelo implica no mesmo trabalho. $\mathrm{O}$ título fala por si só sobre essa relação: mulher ruiva agachada nua, bem referencial, como a própria relação entre os dois. Lautrec parece ter aceitado alguns dos estereótipos de sua classe e gênero. As relações entre homens e mulheres nas cenas nunca é igualitária. Há sempre uma alienação na posição em que ocupam. Essas imagens não são sociais. Há pouco diálogo entre os sexos, tal como a dramaturga escreveu a cena V, entre Pierre e Norah.

Finalmente, para a representação ambígua de Lautrec sobre mulheres das classes baixa, proletárias e prostitutas corresponde o tratamento histórico e 
estético que quisemos dá ao figurino e cenários. Há uma mistura de trajes 'pobres' - como roupas de baixo da época - com trajes usados nas maison closes e trajes de proletárias. O mesmo se dá no mobiliário, que representa as casas de tolerância, com o aspecto rústico das casas sem luz elétrica.

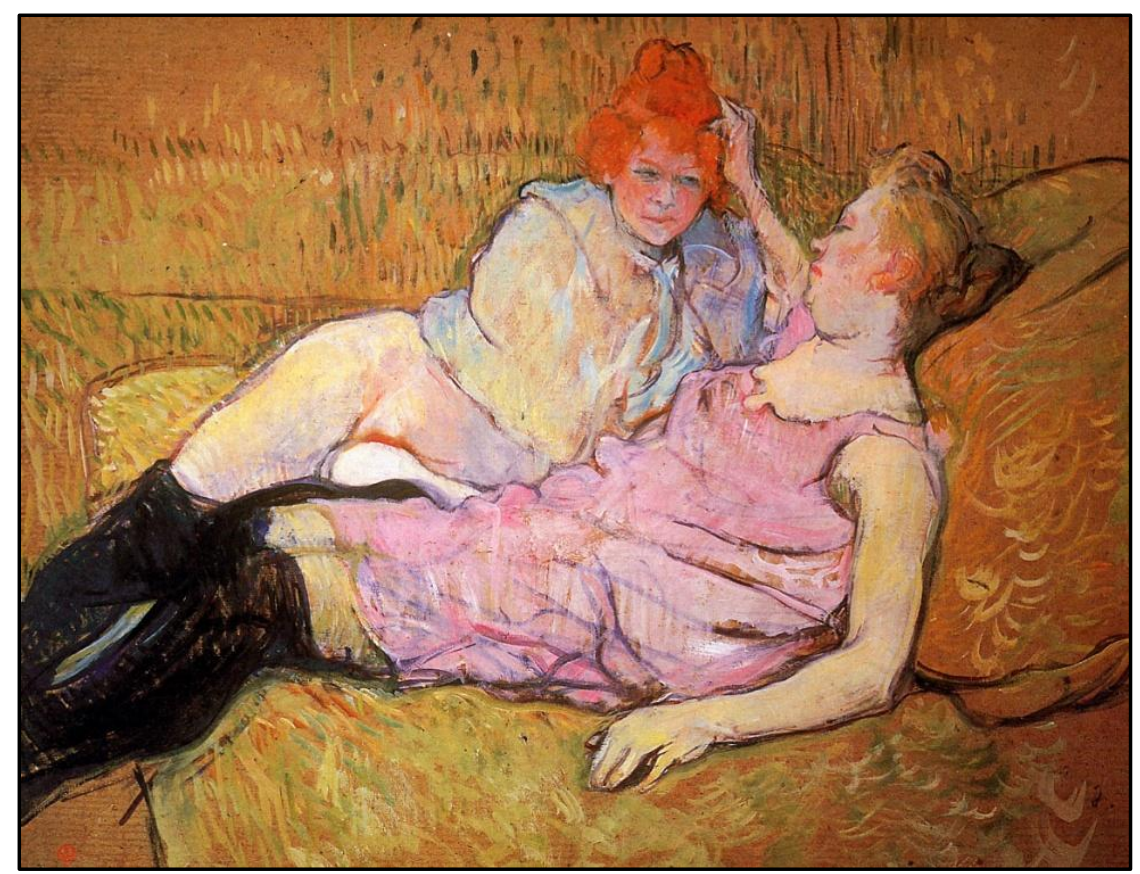

Figura 35: Le sofa - TOULOUSE-LAUTREC (Fonte: Arquivo Pessoal)

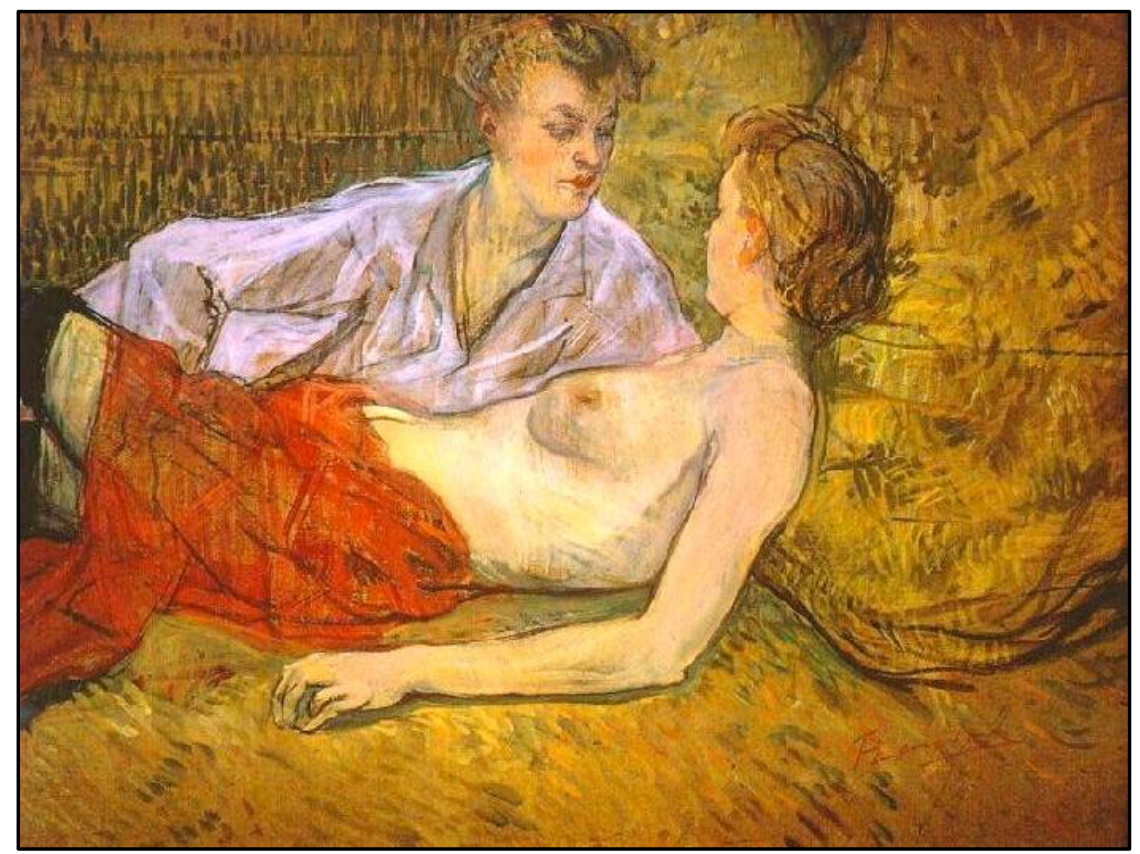

Figura 36: Les deux amies - TOULOUSE-LAUTREC (Fonte: Arquivo Pessoal)

Para concluir, a construção de Norah se deu muito em função da relação entre ela e Margot. Há representação sobre lesbianismo nas pinturas de Toulouse, pois esse era uma dos principais temas dos Decadentistas. Entre elas 
destaca-se Le sofa e Les deux amies. Nelas podemos ver uma relação tanto de suspeita, desconfiança quanto de aceitação. A relação entre as duas personagens passa por essa retratação. Há momentos em que elas parecem ser a mesma personagem, pois há uma inversão das opiniões sobre a vida e os homens. (Figura 35 e 36)

Além das telas, busco o humor sutil e irônico da personagem Angela, vivida por Anna Karina e procuro movimentar-se em cena dentro de um mesmo 'enquadramento', tentando a mesma duração dos planos longos e estáticos de Godard em Viver a Vida.

Outros estímulos também foram usados: fotografias de época, e outras imagens. Em A Saint Lazare (1886), de Jean Béraud mostrava insoumises presas por operarem sem o registro; sob a supervisão de uma freira, elas esperavam para serem cobradas e se submeter à costumeira inspeção médica. Essa imagem serviu de anteparo para o subtexto em que Norah fala sobre seu cansaço em relação à prostituição. Um frame de uma personagem da série televisiva chamada Maison Close foi usado para a cena de abertura. Demais referências foram tiradas do filme L'Apollonide. Todas essas figuras podem ser vistas em Anexos.

\section{b) PROCEDIMENTO 2: Concepção de Figurino}

Minha concepção além de histórica foi bastante influenciada pela proposta mostrada no filme L'Apollonide. As escolhas dos tons de roxo, púrpura e lilás, foram influencia dos tons usados por Toulouse para representar os bordéis, juntamente ao vermelho e bordô, escolhidos por Patusca. ${ }^{42}$

\subsubsection{3. ... E Fêmea - Mostra Experimentos 2012 (TUSP)}

Em Março de 2012, nós fizemos nossa primeira abertura de processo do segundo exercício cênico, o ...E fêmea. Na ocasião, nos apresentamos na Mostra

\footnotetext{
42 Ver imagens em Anexos
} 
Experimentos, organizada pelo Teatro da Universidade de São Paulo. Como a Mostra acontece todo ano, nós já estávamos nos programando para participar dela, dessa forma, todos os ensaios do segundo exercício foram em função de preparar um recorte que pudesse ser apresentado no evento.

Antes de mostrar para o encenador Fabiano, nós já havíamos ensaiado algumas vezes e proposto uma encenação, o que fez com que nesse segundo momento, ele assumisse uma função de diretor dos atores e do músico, João Attuy.

Esse exercício aproxima-se mais do que se está acostumado a ver como uma resultante espetacular. Ainda assim, nós não o consideramos um espetáculo, propriamente dito. ${ }^{43}$ Nossa proposta era de por em cena a dramaturgia textual escrita ao longo do processo, pela atriz. Por uma questão de tempo, nós não tivemos a oportunidade de realizar outros aspectos da encenação que, como artistas, gostaríamos. É provável que, após a conclusão do projeto de mestrado, nós retomemos o processo criativo de ...E Fêmea, certamente para buscar uma cojunção entre os elementos deste com os elementos do primeiro exercício, cuja atenção estava mais voltada para o intercâmbio formal entre as linguagens.

\section{SISTÊMICAS DO OLHAR}

Numa tradução intersemiótica, a tendência é que os signos empregados formem novos objetos imediatos, novos sentidos e novas estruturas que, pela sua própria característica diferencial, tendem a se desvincular do original. Quando elegemos sistemas de signos específicos, como as Artes Plásticas e o Cinema, nós induzimos a linguagem a tomar caminhos e encaminhamentos inerentes à sua estrutura.

Em relação às linguagens experimentadas, não há fidelidade no que se compreende pelo mimetismo dos textos: o discurso aparece reformulado, visível em outros signos que são traduções do signo de partida. Na cena há

\footnotetext{
43 Ver flyer do evento e imagens do exercício em Anexos.
} 
qualidades que nós escolhemos das linguagens, a partir do que foi especificamente estudado e apreendido durante o processo. Levando em consideração o inacabamento, a abertura da obra de arte, sobretudo da obra de arte teatral, Plaza atribui à Tradução como a forma mais atenta de ler.

Citamos:

A Arte não se produz no vazio. Nenhum artista é independente de predecessores e modelos. Na realidade, a história, mais do que simples sucessão de estados reais, é parte integrante da realidade humana. A ocupação com o passado é também um ocupar-se com o presente. O passado não é apenas lembrança, mas sobrevivência com realidade inscrita no presente. As realizações artísticas dos antepassados traçam os caminhos da arte de hoje e seus descaminhos. (PLAZA, p..)

Pensar no que os artistas antes de nós fizeram é ocupar-se com a relação que eles estabeleceram com a linguagem artística na qual sua arte se expressa. Mais que é isso é entender também como eles dialogaram com todos os outros que vieram antes deles, observando o que sobreviveu como realidade inscrita em seu presente, o mesmo aplicando-se a nós.

A criação de novos objetos imediatos e novos significados são formas de inscrever novas realidades. Tais realidades podem ser de três naturezas - foi a isso que chegou Plaza quando propôs uma Tipografia das Traduções. Sendo o pensamento "o único modo de representação" e sendo o ícone o "único meio de transmitir diretamente uma ideia", a tradução como pensamento intersemiótico, trânsito de meios e transmutação de formas, inserirá necessariamente, no seu âmago, as três espécies de signos.

Aqui veremos como os tipos de Tradução correspondem às nossas explanações sobre a Tradução Intersemiótica, no cáp. II. Essa tipografia é para nós também uma proposta de formas de se olhar nossos exercícios cênicos.

\subsection{Tradução Icônica}

A tradução icônica se pauta pelo "princípio de similaridade de estrutura". Há uma analogia entre os Objetos Imediatos, havendo, assim, uma equivalência entre o igual e o parecido, que demonstram a "vida cambiante" da 
transformação sígnica. É como se a tradução icônica produzisse significados de similaridade, sob a forma de qualidades e de aparências.

Essa tradução tende a aumentar a taxa de informação estética. Consequentemente, a tradução como ícone, estará desprovida de conexão dinâmica com o original que representa; ocorre simplesmente que suas qualidades materiais farão lembrar as daquele objeto, despertando sensações análogas. A Tradução Icônica produzirá significados sob a forma de qualidades e de aparências entre ela própria e seu original. Será uma transcriação.

Podemos dizer que houve tradução icônica quando, em cena, apontamse relações de semelhança morfológica que tende à modelização. Isto é, quando pelo gestual e por seus adereços, as atrizes assemelham-se ás figuras do quadro à a caracterização de Anna Karina, nos dois filmes de Godard.

\subsection{Tradução Indicial}

Na tradução indicial há contiguidade entre original e tradução. O objeto imediato do original é apropriado e transladado para outro meio. Nessa mudança, tem-se transformação de qualidade do Objeto Imediato, pois o novo meio semantiza a informação que veicula. Na operação de translação, pode-se deslocar o todo ou parte.

A Tradução Indicial estará determinada pelo seu signo antecedente; contudo esta relação será de causa-efeito (caso da tradução de um signo para outro meio) ou terá uma relação de contiguidade por referência que se resolverá na sua singularidade, pois acentuará os caracteres físicos do meio que acolhe o signo. Contudo, ela será interpretada através da experiência concreta. A tradução será neste caso uma transposição.

Podemos dizer que há transposição em nossos exercícios cênicos quando percebemos relações de rastro, ou evidências da presença de um referente singular, tendendo à individualização. São desse tipo, vários índices de recorte histórico que fizemos. 


\subsection{Tradução Simbólica}

Esse tipo de Tradução opera pela contiguidade instituída, o que é feito através de metáforas, símbolos ou outros signos de caráter convencional. Ao tornar dominante a referência simbólica, eludem-se os caracteres do Objeto Imediato, essência do original. A tradução simbólica define a priori significados lógicos, mais abstratos e intelectuais do que sensíveis.

Ela relacionará com seu objeto por força de uma convenção, sem o que uma conexão de tal espécie não poderia existir, pois como símbolo consistirá numa regra que determinará sua significação. Neste caso, a tradução é transcodificação. Finalmente, a tradução como processo simbólico irá determinar as leis de como "um signo dá surgimento a outro", pois o símbolo "é uma lei ou regularidade de futuro indefinido", uma lei que governará e será materializada e que determinará algumas de suas qualidades, unindo o sensível ao inteligível, isto é, será uma forma significante.

São transcodificações, as relações de pura convencionalidade dependente do código/repertório em jogo que tendem à arbitrariedade, como aqueles em que se traduz um movimento de câmera ou a qualidade estática de uma pintura. A forma como o código imprime uma lei diz muito sobre o discurso daquele texto, assim podemos chegar à tradução simbólica também como convergência textual.

\section{CONSIDERAÇÕES FINAIS}

Como se começa um processo criativo em Teatro? Pode-se pensar no texto de literatura dramática e nos grandes dramaturgos que dão início à montagem teatral, mas pode-se pensar também em outros começos que não esse. Nesse lugar exato é que esta pesquisa esteve localizada. Uma proposição e observação da transmutação que vem por outras vias que não as já pertencentes ao código teatral. 
Para interpretar códigos e signos, as possibilidades são - ou deveriam ser - infinitas, porém, elas dependem do repertório e contexto de quem os lê. O sujeito com repertório limitado e/ ou imerso num contexto repressor tende a ter poucas possibilidades de interpretação. Um sujeito cujo senso crítico é estimulado tende a questionar mais as regras de codificação de uma linguagem, abrindo suas possibilidades interpretativas, gerando maior autonomia e capacidade criativa.

Nossos dois exercícios cênicos ilustram a individualidade de cada processo e dos sujeitos que estão envolvidos neles. O resultado é o 'ponto final suportável' de que nos fala a professora Cecília Salles, quando explica que os estudos genéticos confrontam o que a obra é, o que ela foi, com o que poderia ter sido - ou ainda, com o que ela quase foi. Isso nos ajuda a relativizar a conclusão tanto do processo criativo quanto do corpus da pesquisa.

Ao término, os 'nós da rede', ou seja, as recorrências que amaram e sustentam o processo, tornam-se mais evidentes e contribuem para criar o afastamento para refletir o processo para além da narrativa do mesmo.

O que eles mais nos evidenciam no final desta etapa é a relação entre Tradução e Estímulo que percebo o quanto, ao longo do processo, tentei entender e esclarecer. Pedagogicamente, concluo que a forma com que tradicionalmente utilizam-se as Artes Plásticas e o Cinema no processo criativo teatral passa muito pela questão do estímulo. Assim, penso não se tratar de um processo de tradução e, sim, de livre-associação de ideias.

A Semiótica é considerada uma ciência exatamente por nos permitir compreender o deslocamento e desdobramento de um signo em outro. Mas se pensarmos em inspiração, estaremos falando e algo mais aleatório, onde as tendências das escolhas podem não ficar claras para quem os faz. Assim, há a chance de não ser um processo consciente. Com a tradução, quisemos trazer a escolha para a consciência, para que o ator saiba escolher tecnicamente e esteticamente para além do gosto. Quanto à encenação e aos textos utilizados nossa maior conclusão é quanto à representação feminina, em momento chaves de nossa história: final do séc. XIX, começo do séc. XX e os anos 60. 
Muitas dessas referências e suas imagens ainda não estão completamente problematizadas. E com certeza trazem ao espectador questões da antiga cidade moderna que sem dúvida ainda nos influenciam fortemente hoje: classe, gênero, ambiguidade, exploração, alienação. Nós nos questionamos: Elas não inferem em limites entre - para usar os termos tradicionais - burguesia e proletariado, entre público e consumidor, artista e produto?

Ao tratarmos da prostituição, encontramos muitas das origens históricas para o deslocamento dessas mulheres dos bordéis para o boulevard ${ }^{44}$, e também a mudança tom com que se falava das prostitutas. ${ }^{45}$. Já a construção do feminino construída por Godard põe em questão o discurso proferido em vésperas de revolução sexual, pelo uso de ambiguidade e ironia. Partimos da pintura e do cinema porque são materias concretos, mas todo processo pode ser intersemiótico, basta que a ideia central seja localizada em uma linguagem.

Quando iniciei este projeto, não tinham ideia de quais artistas trabalhariam comigo e à quais textos eles me levariam. Entretanto, sempre considerei isso uma grande vantagem do ponto de vista da pesquisa, pois acredito que, tal qual o signo, é na diversidade que está sua riqueza, e principalmente nos indivíduos, como seres da linguagem que está a chave para todos os significados.

${ }^{44} \mathrm{O}$ confinamento na maison close não comportou o crescente caráter fluídico da prostituição parisiense; a madame controlava as condições, os clientes, as roupas, e ficava com metade dos lucros. Era mais congênito e lucrativo trabalhar independentemente ou in brasserie de femmes, um café que funcionava como um fronte para os quartos privados.

${ }^{45}$ Publicações como La Prostitution à Paris (1890) e La Corruption fin-de-siècle (1891) insistia que as filles de maioson fossem tratadas como seres individuais, em uma abordagem mais humana. É dentro desse contexto que as imagens sobre prostituição de Toulouse-Lautrec devem ser colocadas e lidas. Foi dessa forma que nós as abordamos em buscas de signos. De toda forma, em retratar as cenas eróticas nos bordéis, Lautrec deixou de mostrar a outra metade comercial da equação do bordel: o cliente masculino. 


\section{BIBLIOGRAFIA}

ANDREW, James Dudley. As principais teorias do cinema: uma introdução. Tradução de Teresa Ottoni. Rio de Janeiro: Jorge Zahar. 2002.

APPIA, Adolphe. A Obra de Arte Viva [1921]. Edição de Eugénia Vasques. Escola Superior de Teatro e Cinema, 2002. $2^{\mathrm{a}}$ edição 2004. $3^{\mathrm{a}}$ edição 2005.

ARTAUD, Antonin. Teatro e Metafísica. In: [nome do organizador seguido da palavra (org.) entre parênteses. Ex. SILVA, João (org.). ]. O teatro e seu duplo. São Paulo - SP, 2004.

BAKHTIN, Mikail. A cultura popular na Idade Média e no Renascimento. São: Hucitec, 1987.

BARBA, Eugene; SARARESE, N. A arte secreta do ator. Campinas, SP: UNICAMP, 1995.

BARTHES, Roland. Elements of Semiology. New York: Hill and Wang, 1968.

. Da obra ao texto. In: [nome do org.]. O rumor da língua. Martins Fontes, São Paulo, 2004a.

A morte do autor. In: [nome do org.]. O rumor da língua. São Paulo: Martins Fontes, 2004b.

BATALHA, Maria Cristina. Tradução de Geraldo Pontes Jr. Petrópolis, RJ: Vozes, 2007.

BAUMGÄRTEL, Stephan. A co-presença do semiótico e do performativo (slide, 2010).

A fala teatral, idem

As didascálias - descrição cênica e expressão poética.

BOGATYREV, Petr. Porto Alegre: Globo, 1977, p. 17.

BONFITTO, Matteo. O ator compositor. São Paulo: Perspectiva, 2002.

CAMPOS, Haroldo de. Da tradução como criação e como crítica. In: [nome do org.] Metalinguagens. Petrópolis, 1967, p. 21-28.

CARRIÈRE, Jean-Claude. A linguagem secreta do cinema.Tradução de Fernando Albagli e Benjamin Albagli. $1^{\mathrm{a}}$ ed especial. Rio de Janeiro: Nova Fronteira, 2006. 
DESGRANGES, Flávio. A pedagogia do espectador. São Paulo, HUCITEC, 2003.

ECO, Umberto. Tratado geral de semiótica. São Paulo: Perspectiva, 2000.

EISENSTEIN, Serguei. O Sentido do filme. São Paulo: Jorge Zahar, 2002a.

EISENSTEIN, Serguei. A Forma do filme. São Paulo: Jorge Zahar, 2002b.

FISCHER-LICHTE. Walter Benjamin's Concept of Allegory. A paradigm of Avant garde Art? In: [nome do org.] The Show and the Gaze of Theatre. A European Perspective. Iowa City: University of Iowa Press, 1997. p. 275-289.

GARDNER, Howard. Estruturas da Mente. Porto Alegre: Ed Artes Médicas Sul, 1994.

GRÜNEWALD, José Lino. Um filme é um filme: o cinema de vanguarda dos anos 60. CASTRO, Ruy (org.). São Paulo, Companhia das Letras, 2001.

GUINSBURG, J. Stanislávski, Meierhold \& Cia. São Paulo: Editora Perspectiva, 2001.

HOLMES, S. J. The name and nature of translation studies. In: [nome org.] The translation studies reader. New York: Routledge, 2004.

JAKOBSON, Roman. Aspectos Linguísticos da Tradução. In: [nome org.]. Linguística e Comunicação. São Paulo, 1970.

KOWZAN, T. O signo teatral: a semiologia aplicada à arte dramática. Porto Alegre: Globo, 1977.

LEHMANN, Hans-Thies. Teatro Pós-dramático. Tradução Pedro Süssekind. São Paulo: Cosac\&Naífy, 2007.

LEONE, Eduardo. Reflexões sobre a montagem cinematográfica. Seleção e textos de Erika Savernini, Heitor Capuzzo..Belo Horizonte. Editora UFMG, 2005.

OSTROWER, Fayga Perla. Universos da Arte. Rio de Janeiro: Campus, 1983.

PEIRCE, S. C. What is a sign?. In: [(org.). The essential Pierce: Selected Philosophical Writings. Volume 2. (1893 - 1913). Indiana: Indiana University Press, 1998.

PLAZA, Júlio. Tradução Intersemiótica. São Paulo: Perspectiva, 1987, p. 26. 
RYNGAERT, J. P. Introdução à análise do teatro. São Paulo: Martins Fontes, 1996.

SAGNE, Jean. Toulouse-Lautrec /Jean Sagne. Tradução de Antônio Carlos Viana. Imprenta. Porto Alegre: L\&PM, 1990.

SANTAELLA, L. Estética de Platão a Peirce. São Paulo: Experimento, 1994.

SANTAELLA, L. O que é semiótica. São Paulo: Brasiliense, 2007.

SILVA, Armando Sérgio. Interpretação: uma oficina da essência. São Paulo: ECA-USP, 1999.

STEIN, Gertrude. Peças. Uma conferência. Manuscrito não publicado.

STEPHERSON, Ralph. O cinema como arte. Zahar: Rio de Janeiro, 1965, p. 36. O cinema como arte. Zahar: Rio de Janeiro, 1969.

STEPHENSON, Ralph; DEBRIX, Jean R. O cinema como arte. Rio de Janeiro: Zahar, 1969. 


\section{FILMOGRAFIA}

Acossado (Jean-Luc Godard, 1959)

Blow Up (Michelangelo Antonioni,1967)

Brumas de Outono (Dimitri Kirsanoff, 1928)

Fahereint 451 (François Truffaut, 1966)

Reconstruction (Christophe Boe, 2003)

Irreversível (Gaspar Noé, 2002)

L'Apollonide - Souvenirs de la maison close (Bertrand Bonello, 2011)

Marie Antoinette (Sophia Coppola, 2004)

Moulin Rouge (John Huston, 1952)

My Blueberry Nights (Won Kar Wai, 2008)

O Espelho (Andrei Tarkovski,1974)

Uma mulher é uma mulher (Jean-Luc Godard, 1961)

Viver a Vida (Jean-Luc Godard / 1962) 
ANEXOS 


\section{Sobre os participantes}

\section{Christiane Martins}

Nascida em Florianópolis (SC), é licenciada em Educação Artística - Artes Cênicas pela Universidade do Estado de Santa Catarina (2006). Atualmente curso mestrado em Artes Cênicas, pesquisando o hibridismo das linguagens artísticas, principalmente entre as Artes Cênicas e Plásticas. Atriz

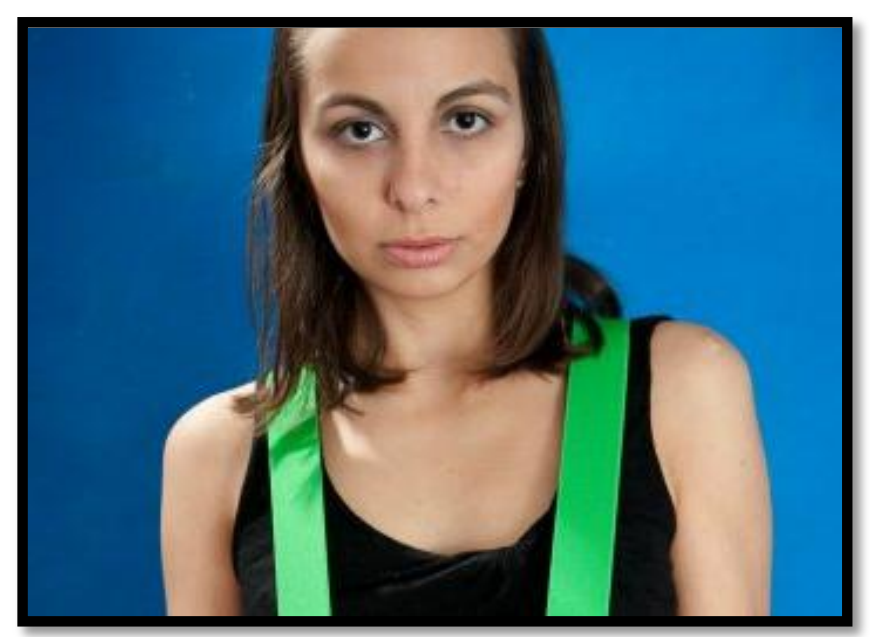
profissional, já participou de espetáculos, tais como 'Valsa Aérea'.

\section{Patusca}

Natural de Belém (PA), tem graduação em Ed. Artística - Habilitação em Artes

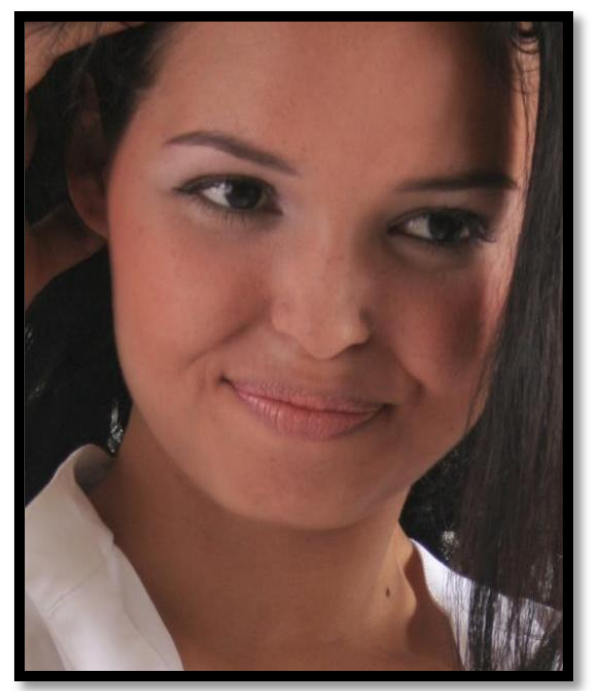
Plásticas - Licenciatura Universidade Federal do Pará. Formação em atriz pela Escola de Teatro e Dança da Universidade Federal do Pará. E pós-graduação Lato Sensu em Patrimônio Histórico e Educação Patrimonial - Faculdade Integrada Brasil Amazônia. Como atriz, tem certa de 12 de carreira, tendo participado dos espetáculos: “Histórias de Contar" (A Patuscada, 2000), MADA (Cia dos Insights, 2008), “Jogo de Sete” (Cia em Cores, 2009), “Já pensou?!” (A Patuscada, 2010) e "Amadores" (Grupo de teatro do Ofício). Como dramaturga, é autora dos textos: “Já pensou?!”, “O Peixe em Histórias de Contar", “Dor e Delícia”, “...E Fêmea”, entre outros. 


\section{Brenda de Oliveira}

Natural de Belém (PA), é graduada pelo curso de licenciatura em Letras - habilitação em Língua Inglesa (2009). Atualmente, é mestranda no curso de Artes Cênicas, com ênfase na linha de pesquisa Formação do Artista Teatral pela Escola de Comunicação e Artes da Universidade de São Paulo (ECA-USP). Está em andamento com o curso Técnico em Formação do Ator pelo SENAC. Atuou em peças como: TRASH - O outro lado do popPORN (2008) e

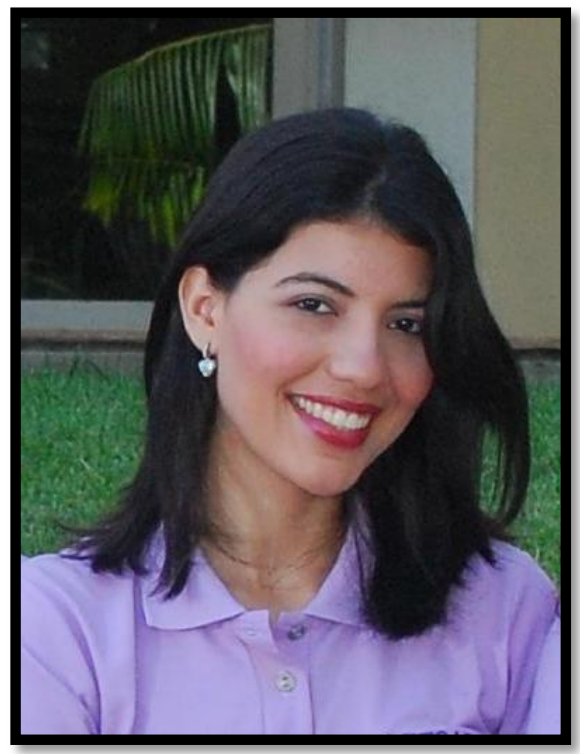
ABSURTOS! (2011).

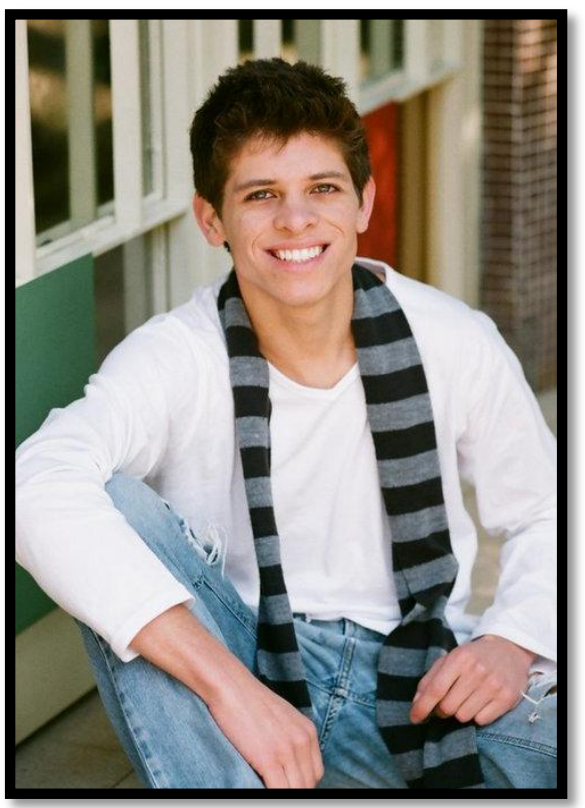

\section{Elton Santos}

Paulistano, é aluno da Escola de Arte Dramática (EAD, turma 61), ator profissional e participou, entre outros, dos seguintes espetáculos: "Dublinenses" (2010) e “A Vida é Sonho" (2011). Atualmente, integra a Cia Teatro da Vertigem e está em cartaz com o espetáculo “Bom Retiro 958 metros". 


\section{João Attuy}

Paulistano, é aluno da Escola de Arte Dramática (EAD, turma 61) é ator profissional e participou, entre outros, dos seguintes espetáculos: "Dublinenses" (2010)

e "Lavoura Arcaica" (2011). Atualmente, integra a Cia Teatro

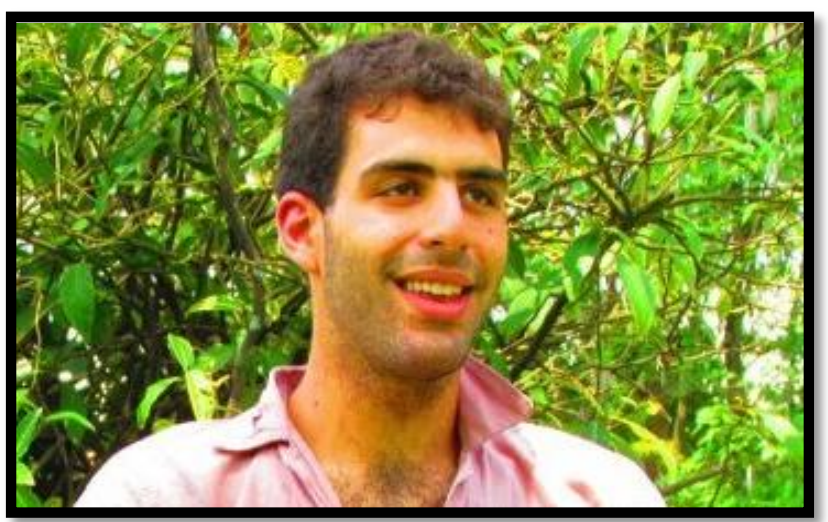
da Vertigem e está em cartaz com o espetáculo "Bom Retiro 958 metros".

\section{Fabiano Benigno}

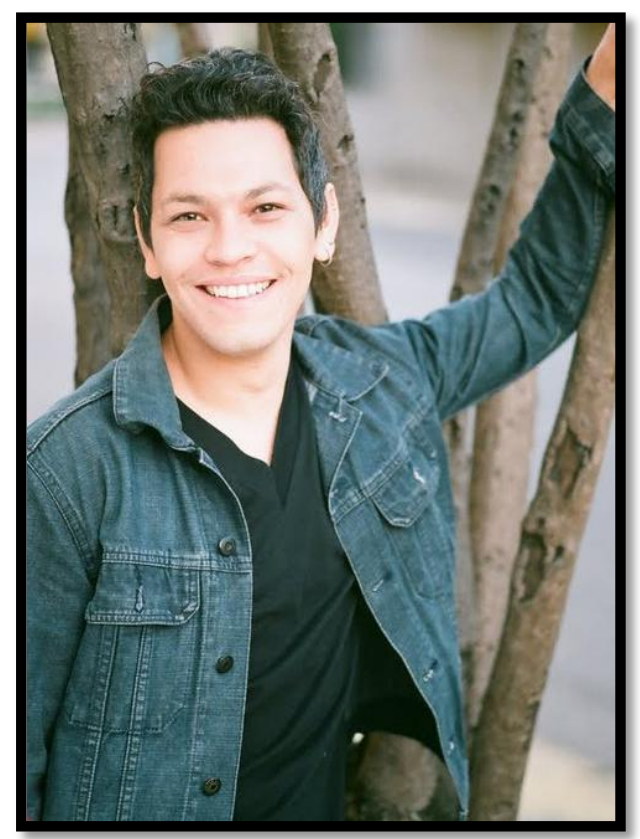

Paulistano, é bailarino, ator formado pela EAD. Como diretor e encenador, dirigiu diversos espetáculos, como: “Terra provisória" (2010), com o qual cumpriu temporada no SESC Consolação. Trabalhou como assistente da Professora Isabel Setti, na Escola de Arte Dramática.

Também participaram da pesquisa as alunas da Escola de Arte Dramática:

\section{- Bruna Lima}

- Áurea Teixeira Barros 


\section{OUTRAS IMAGENS}

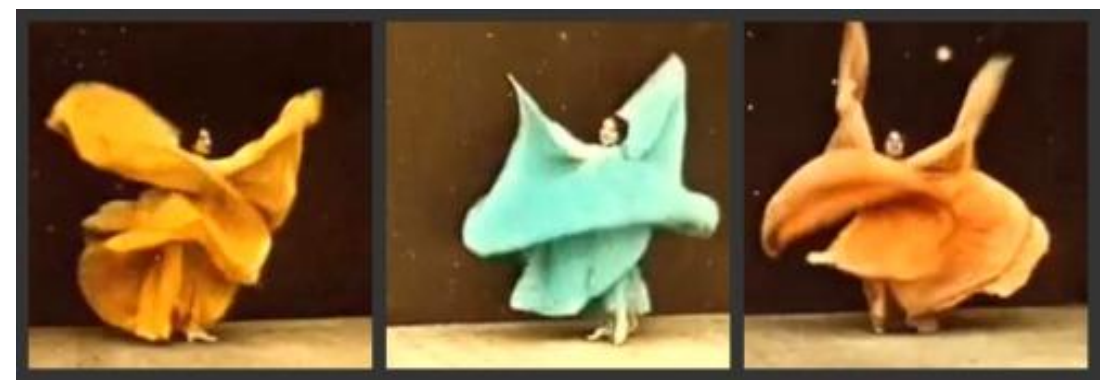

Anexo 1: Loïe Fuller - DANÇA SERPENTINA

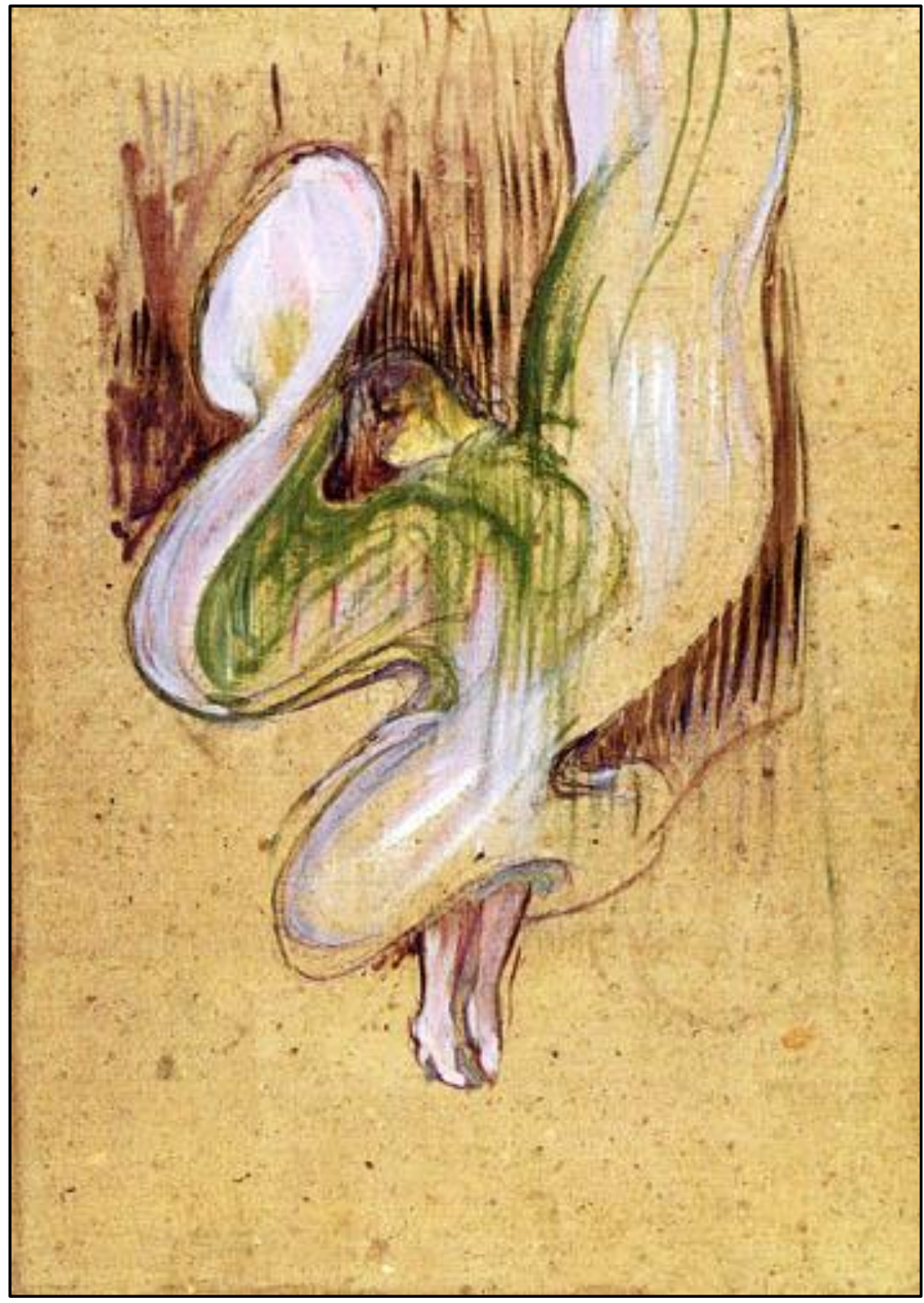

Anexo 2: Loïe Fuller alle Folies Bergère - TOULOUSE-LAUTREC 

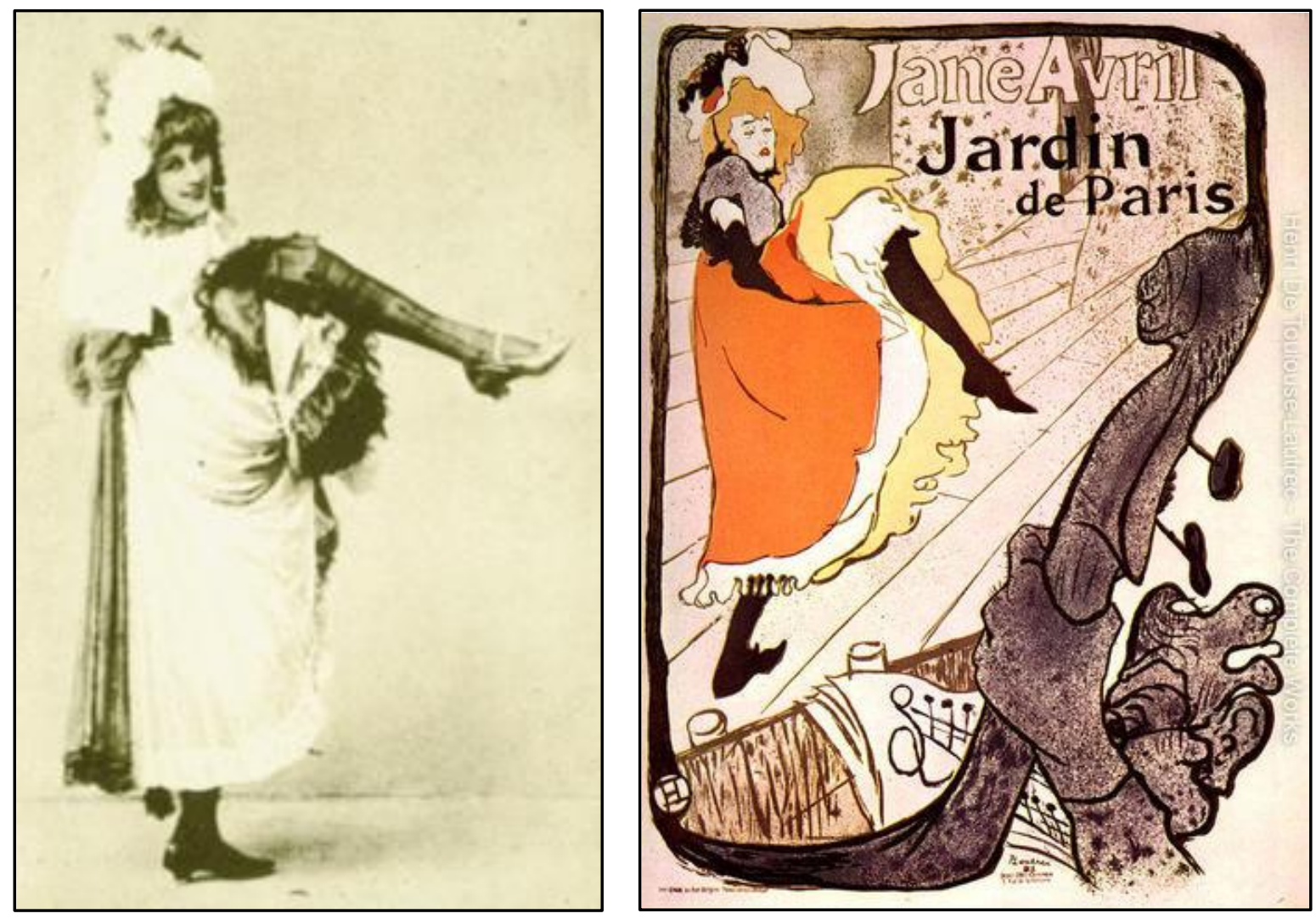

Anexo 3: A dançarina do Moulin Rouge Jane Avril

Anexo 4: cartaz de Jane Avril, Jardin de Paris - TOULOUSE-LAUTREC
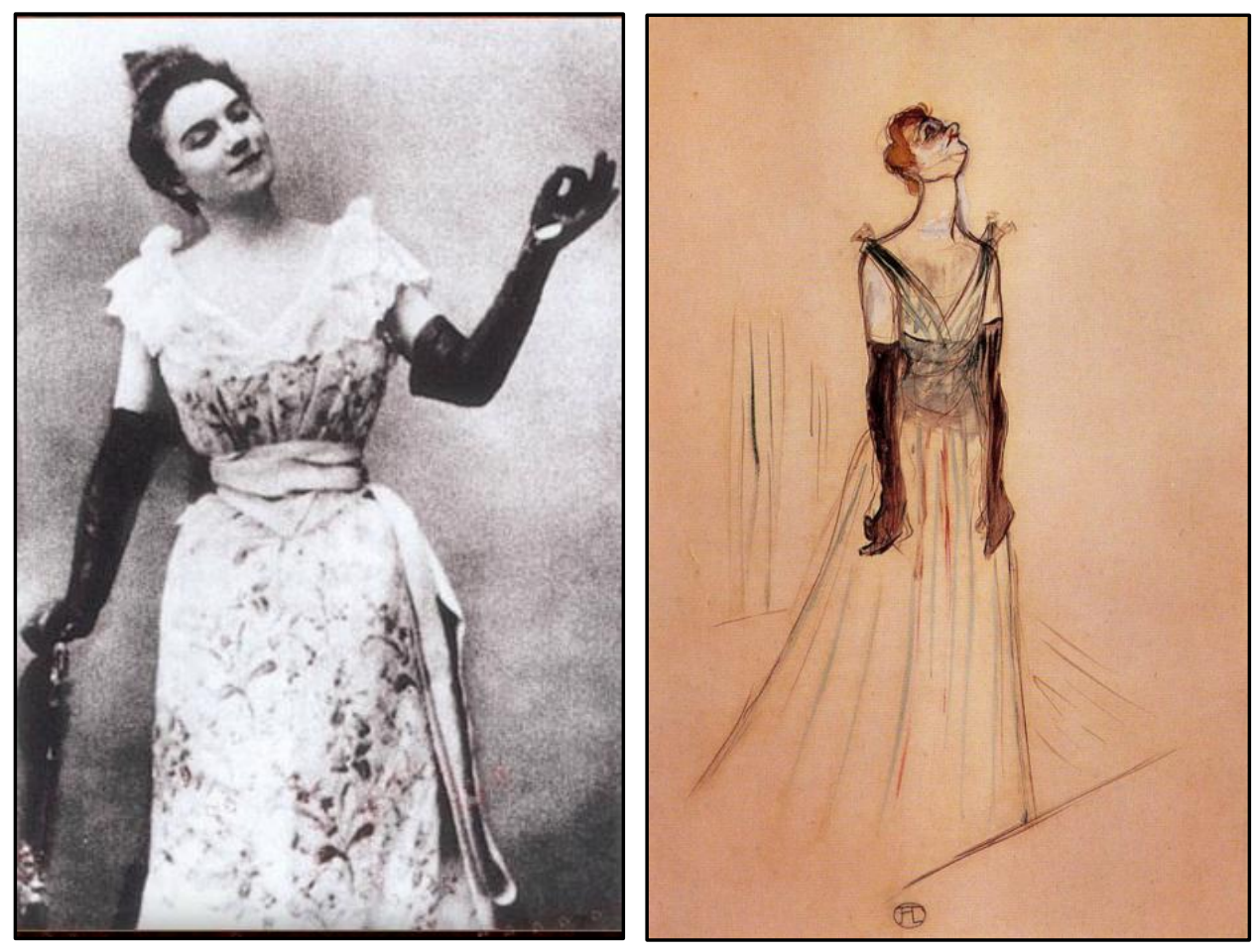

Anexo 5: A cantora Yvette Guilbert

Anexo 6: Yvette Guilbert - TOULOUSE-LAUTREC 

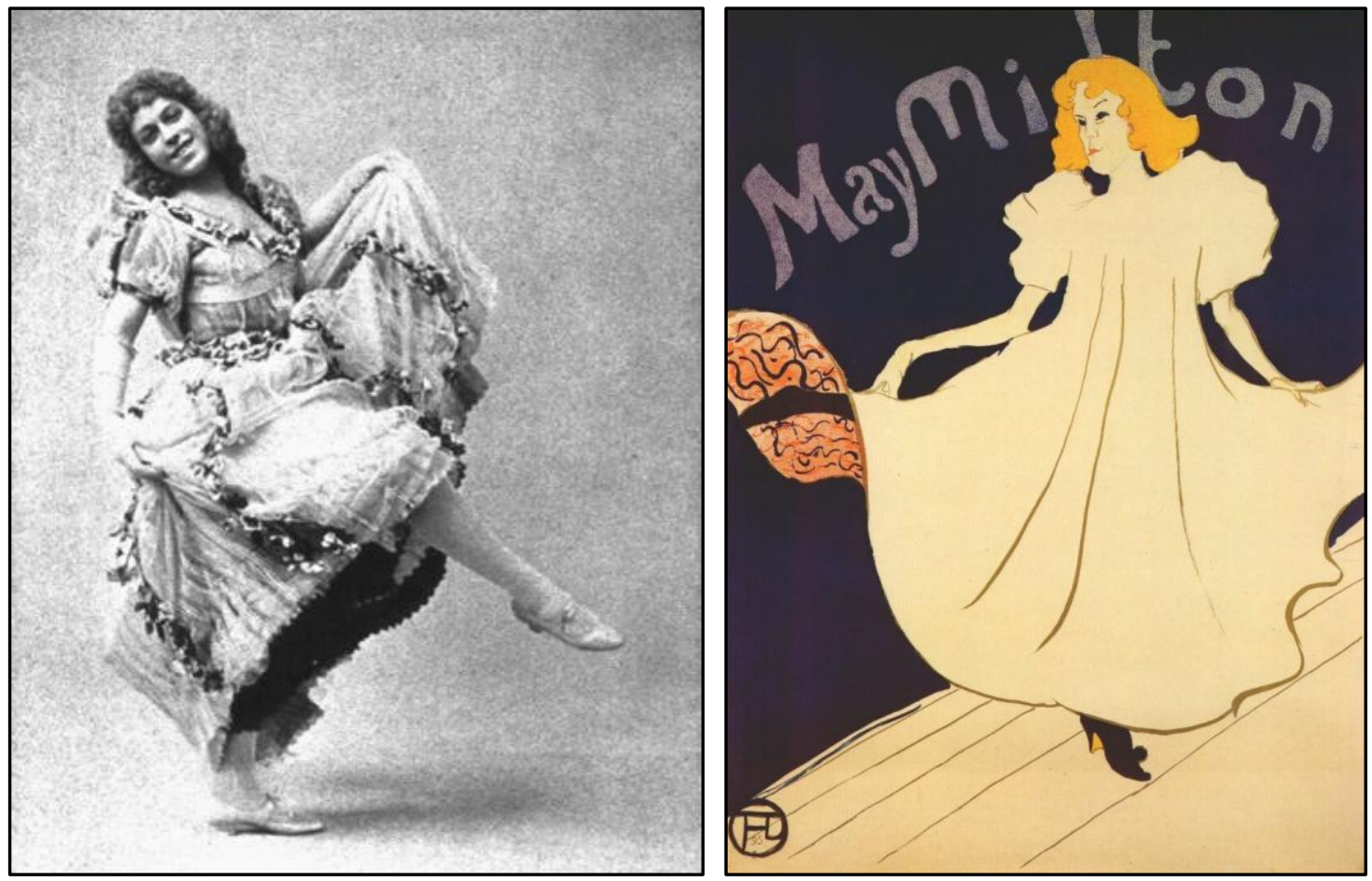

Anexo 7: A dançarina May Milton

Anexo 8: Cartaz para May Milton - TOULOUSE-LAUTREC
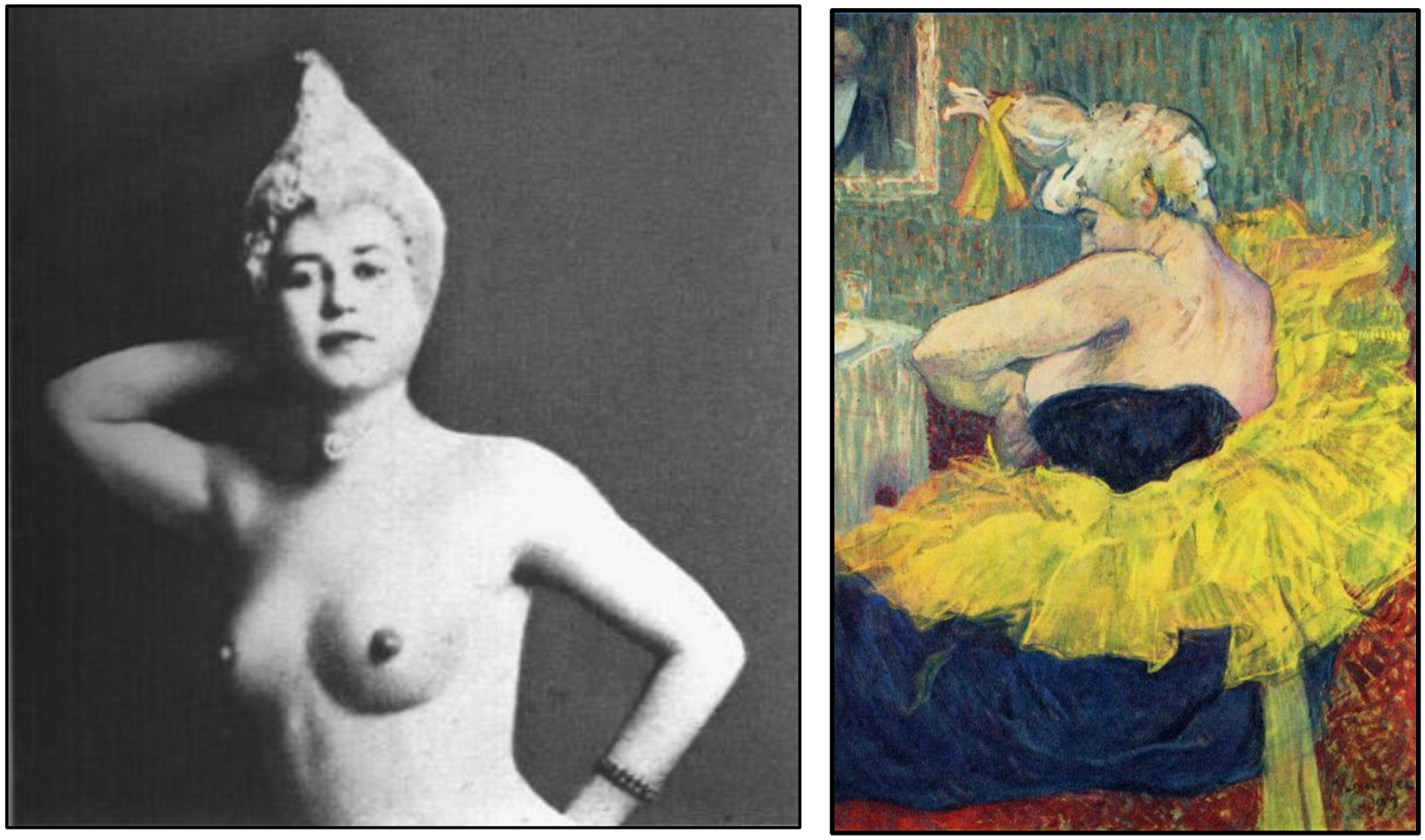

Anexo 9: A 'Lady clowness' Cha-U-Kao

Anexo 10: Cha-U-Kao - TOULOUSE-LAUTREC 

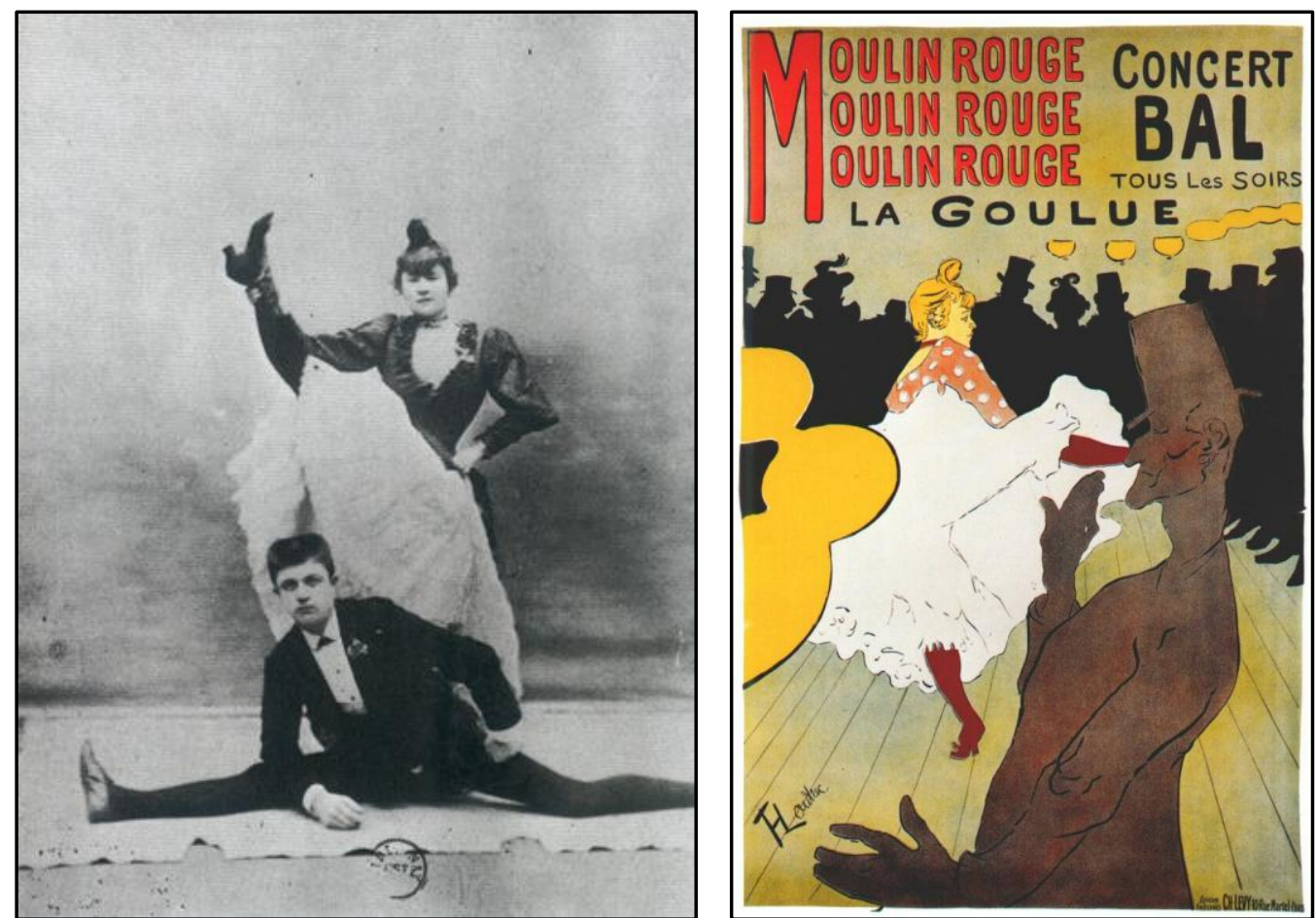

Anexo 11: Louise 'La Goulue' e Valentin 'Le déssosé'

Anexo 12: Primeiro cartaz de Toulouse-Lautrec para o Moulin Rouge - LA GOULUE E VALENTIN 'LE DÉSSOSÉ'
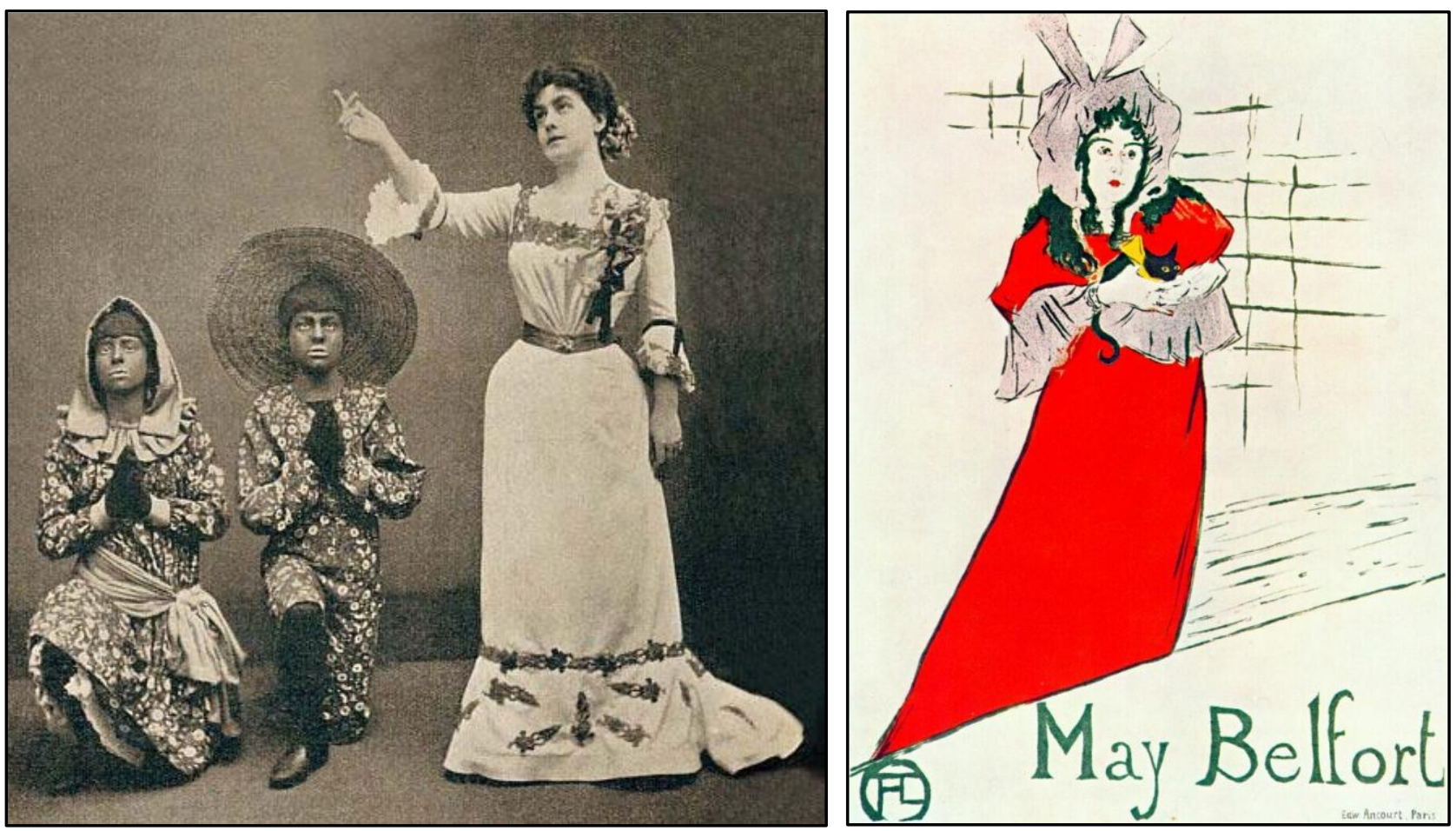

Anexo 13: May Belfort

Anexo 14: A influência japonesa no cartaz de May Belfort - TOULOUSE-LAUTREC 

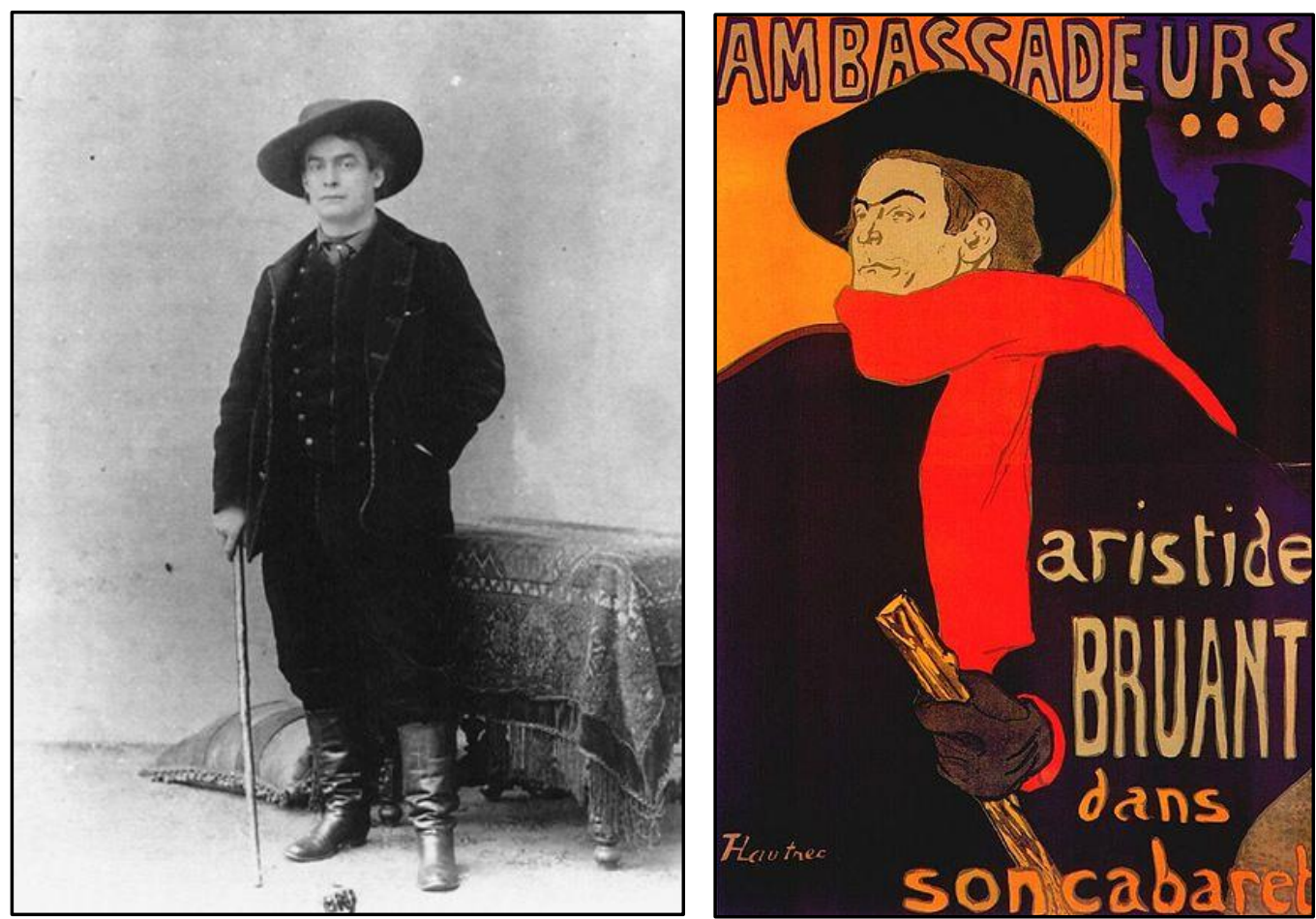

Anexo 15: Aristide Bruant

Anexo 16: Cartaz de Aristide Bruant - TOULOUSE-LAUTREC
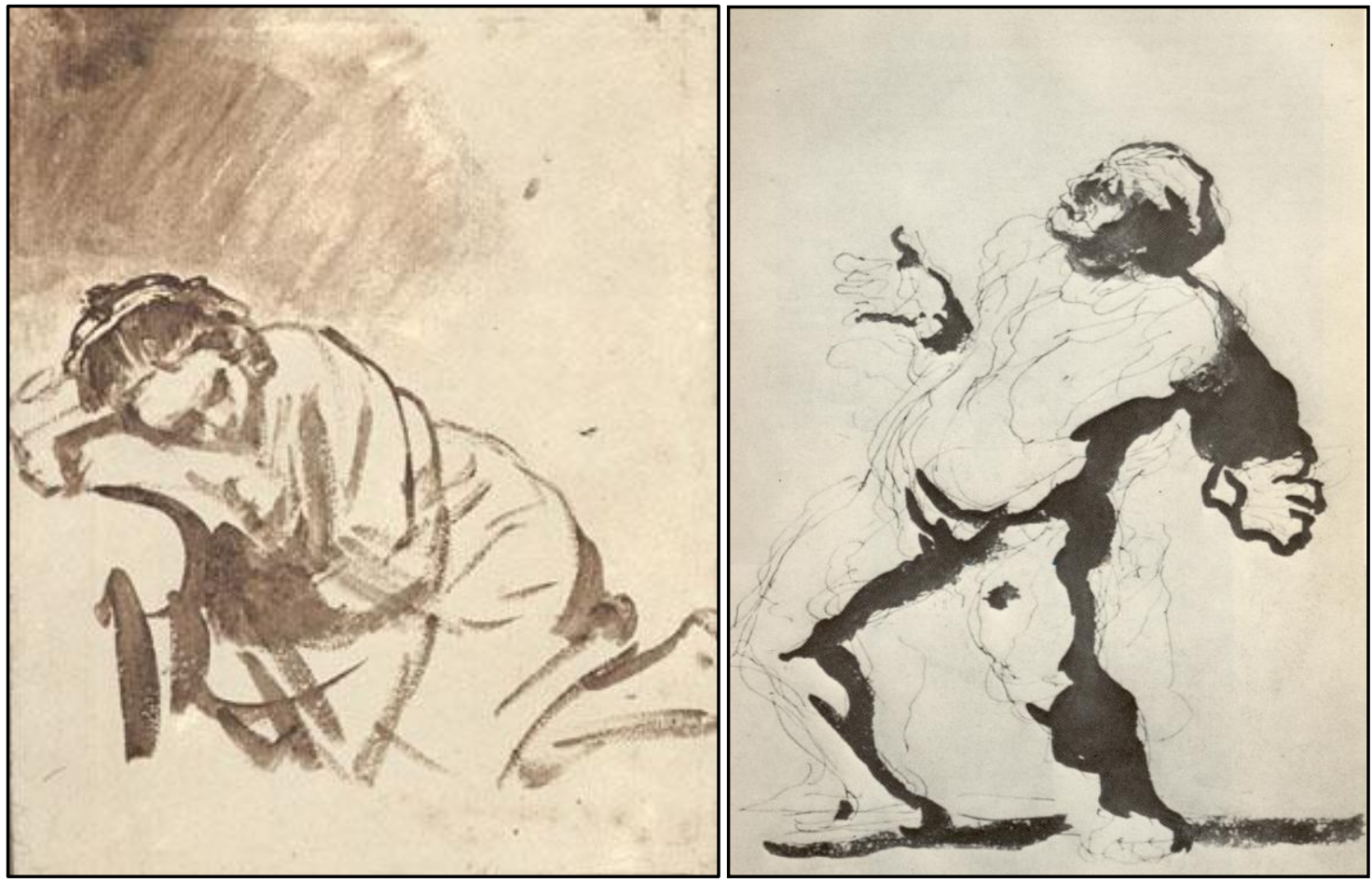

Anexo 17: 'Mulher adormecida', de Rembrandt e ‘Ator no palco', de Honoré Daumier 


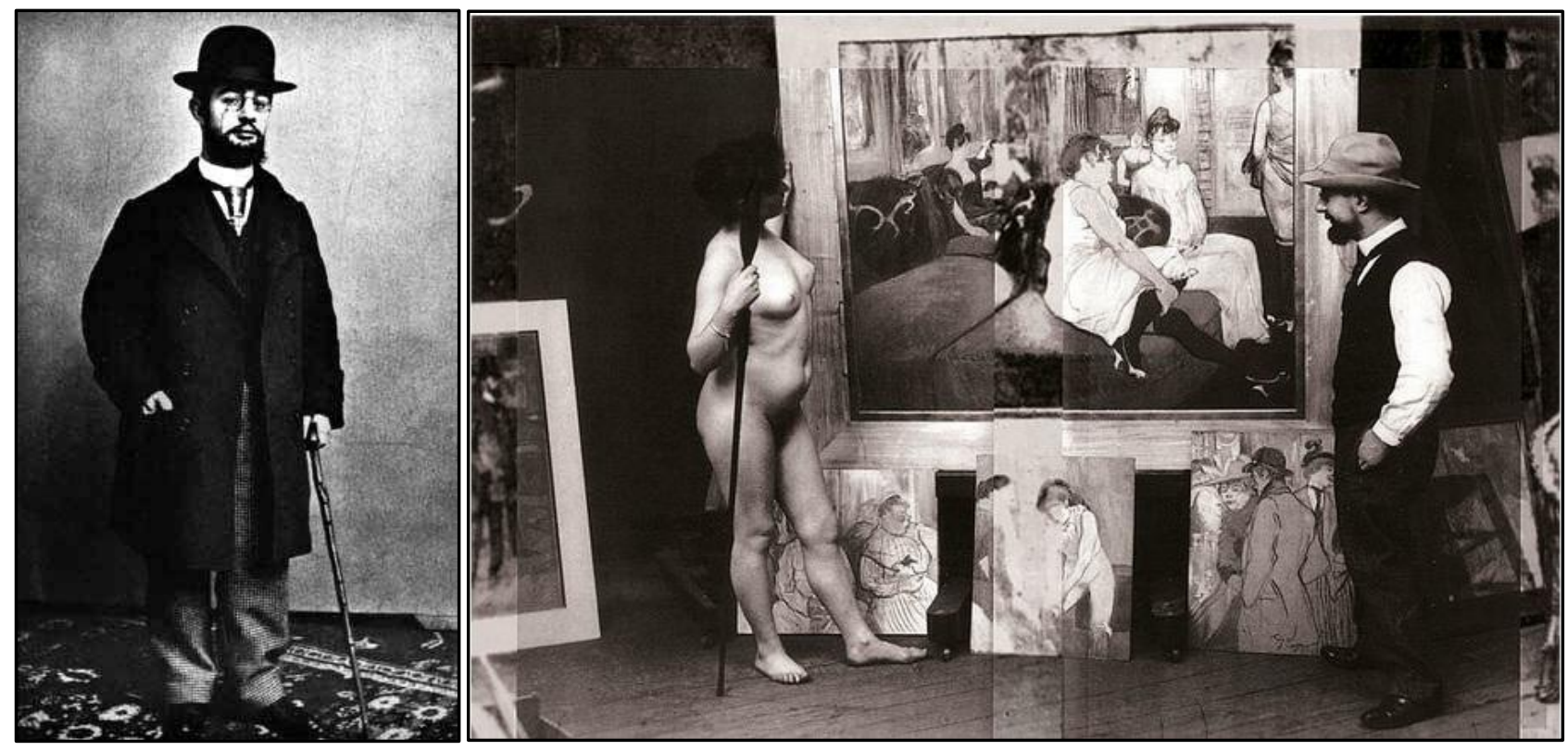

Anexo 18: O pintor Henri de Toulouse-Lautrec. À direita, em seu estúdio com uma modelo.
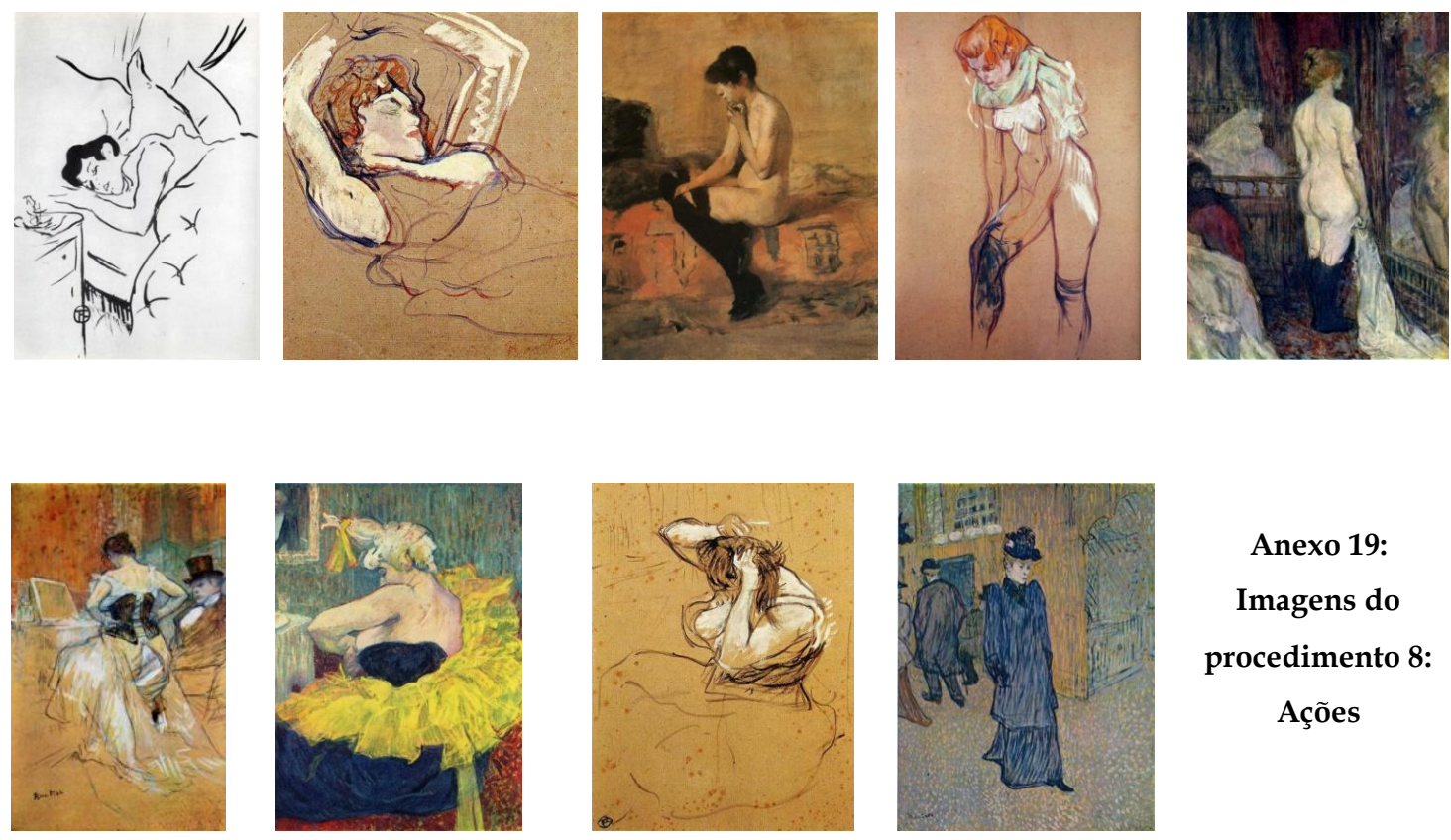

Anexo 19:

Imagens do

procedimento 8:

Ações

Anexo 20: Imagens selecionadas para encontro do dia 16 de Setembro
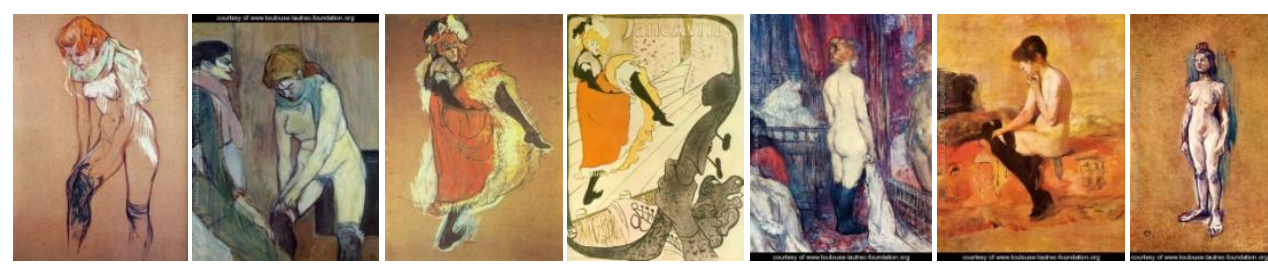
Anexo 21: Imagens Selecionadas para encontro do dia 16 de Setembro II
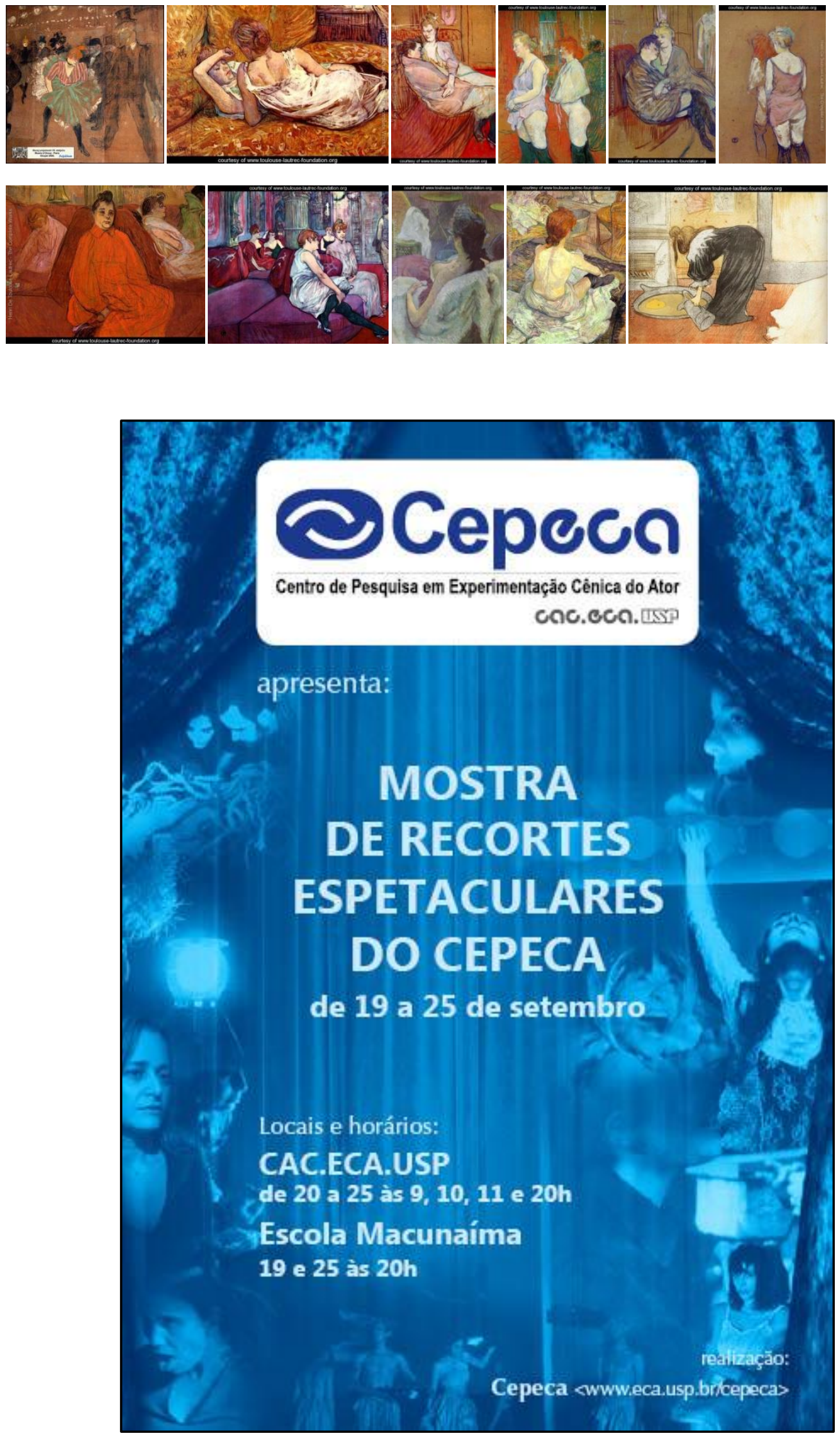

Anexo 22: Flyer da Mostra de Recortes Espetaculares do CEPECA 


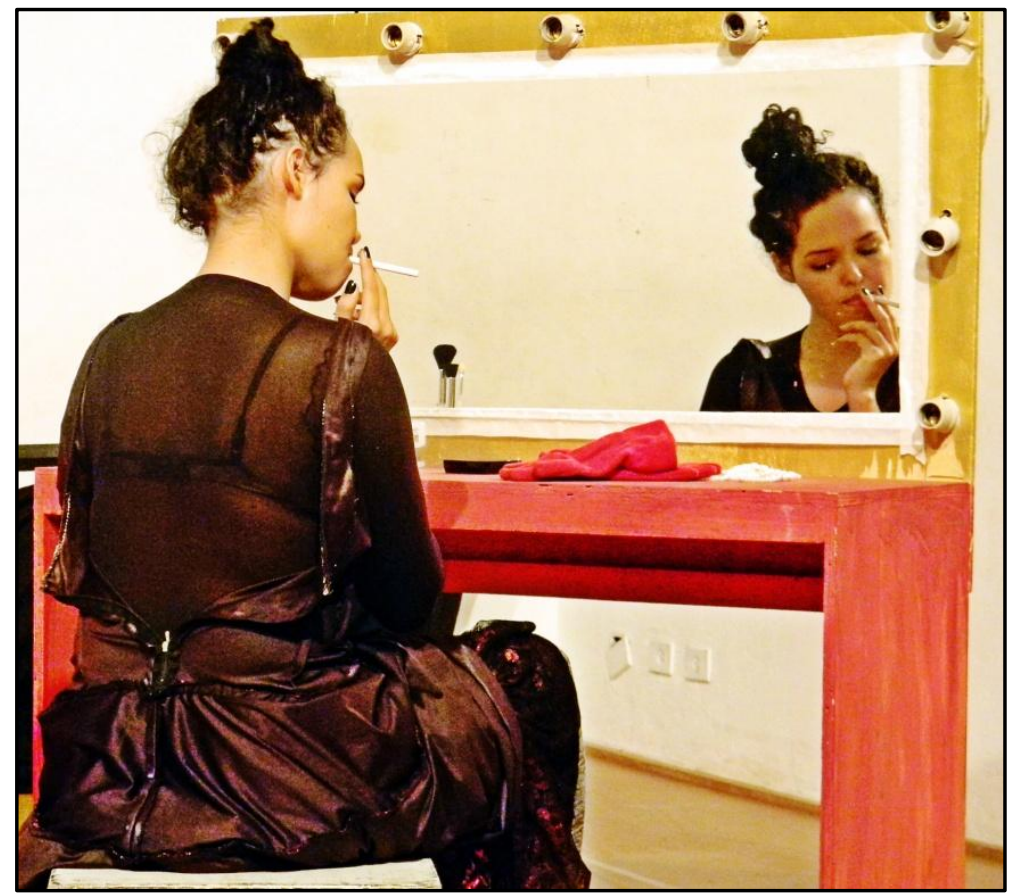

Anexo 23: Fotografia de ensaio - PATUSCA

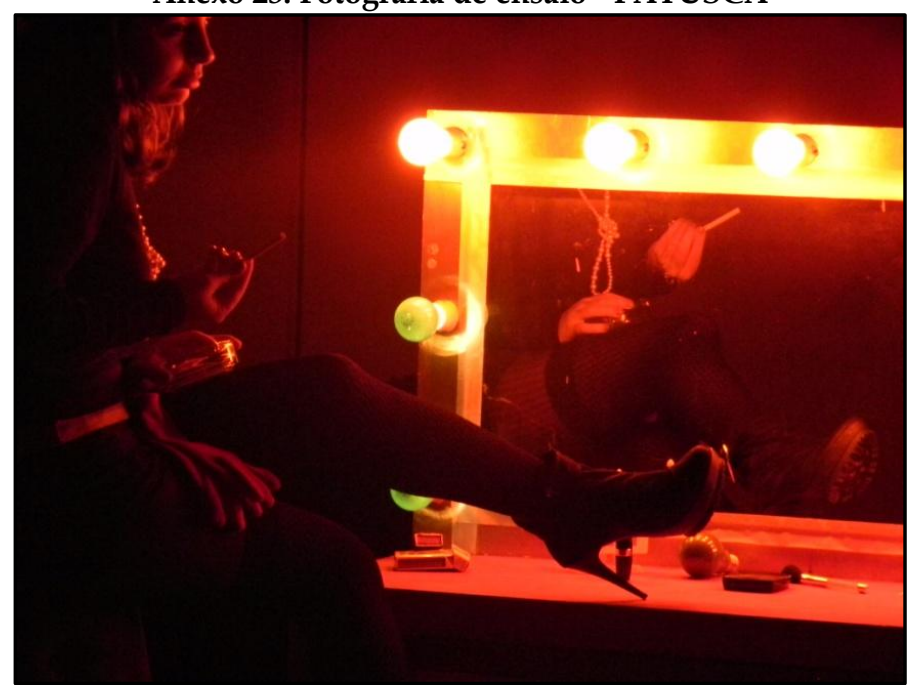

Anexo 24: Fotografia de ensaio - CHRISTIANE

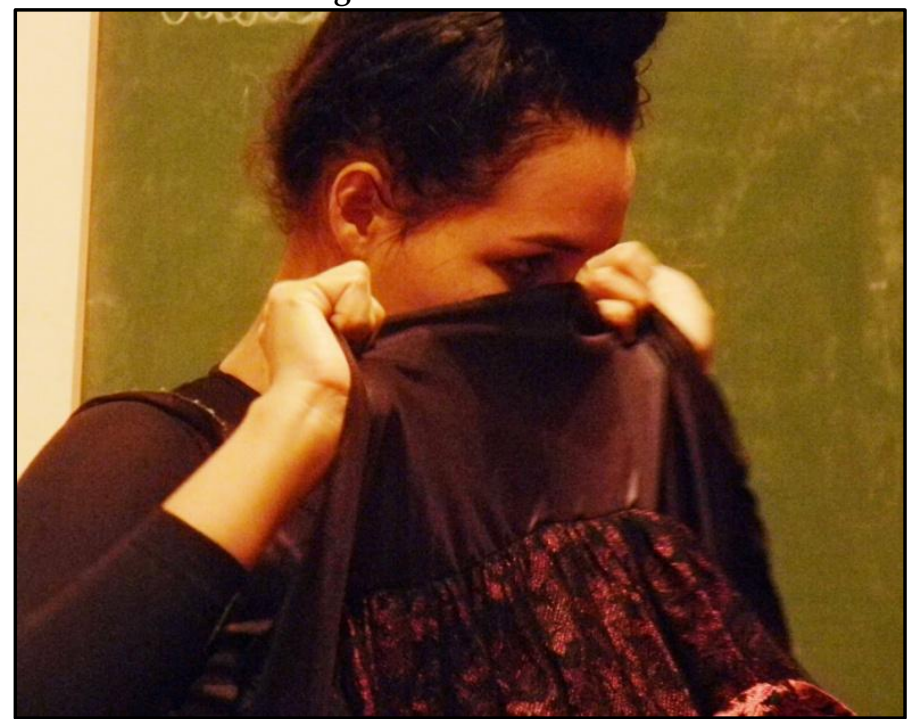

Anexo 25: Fotografia do Ensaio - PATUSCA II 


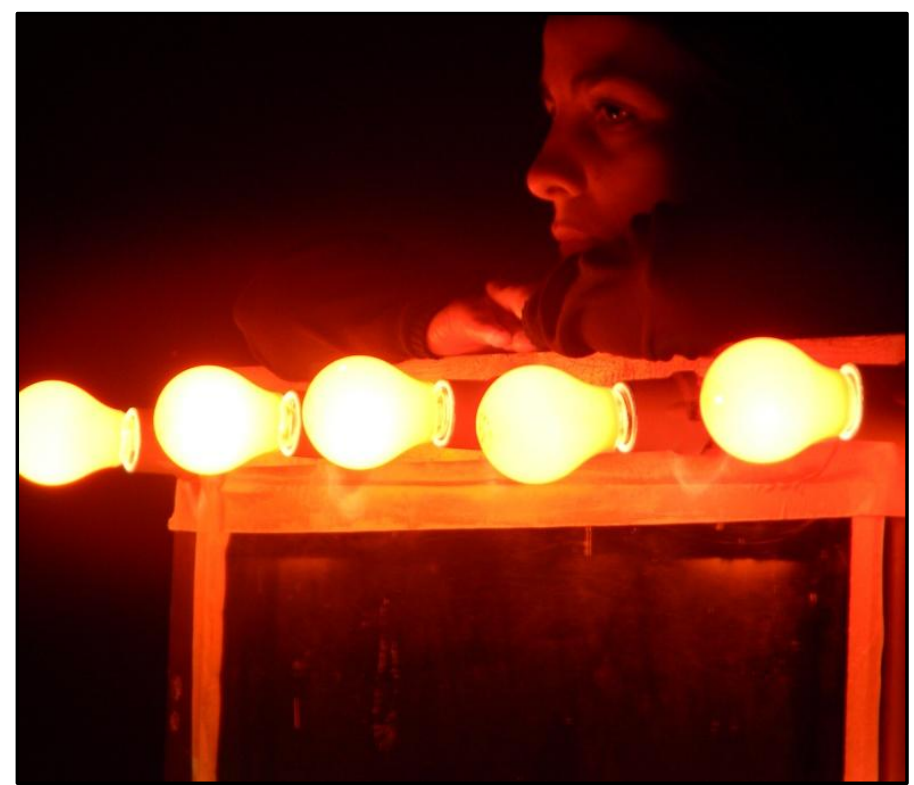

Anexo 26: Fotografia de Ensaio - POR DANILO DO CARMO

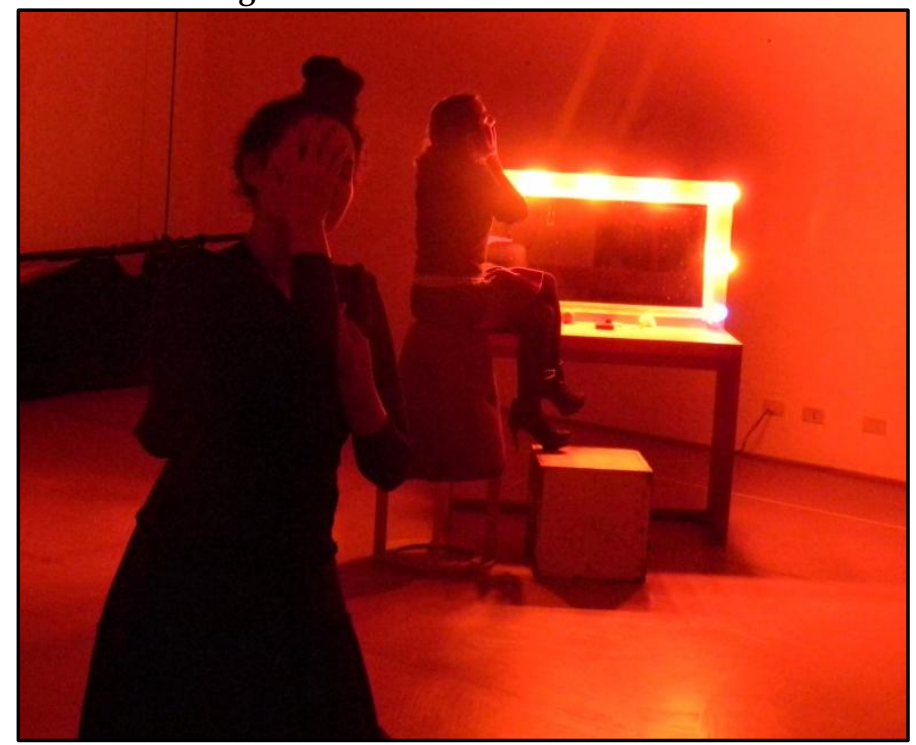

Anexo 27: Fotografia de Ensaio - POR DANILO DO CARMO II

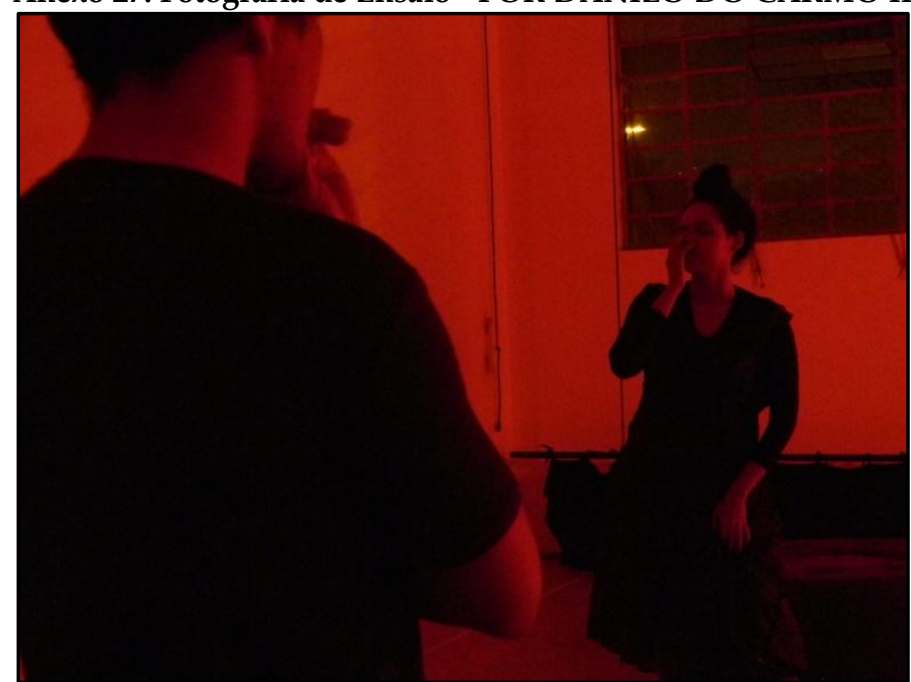

Anexo 28: O encenador Fabiano observa Patusca, em cena - EFÊMEA 

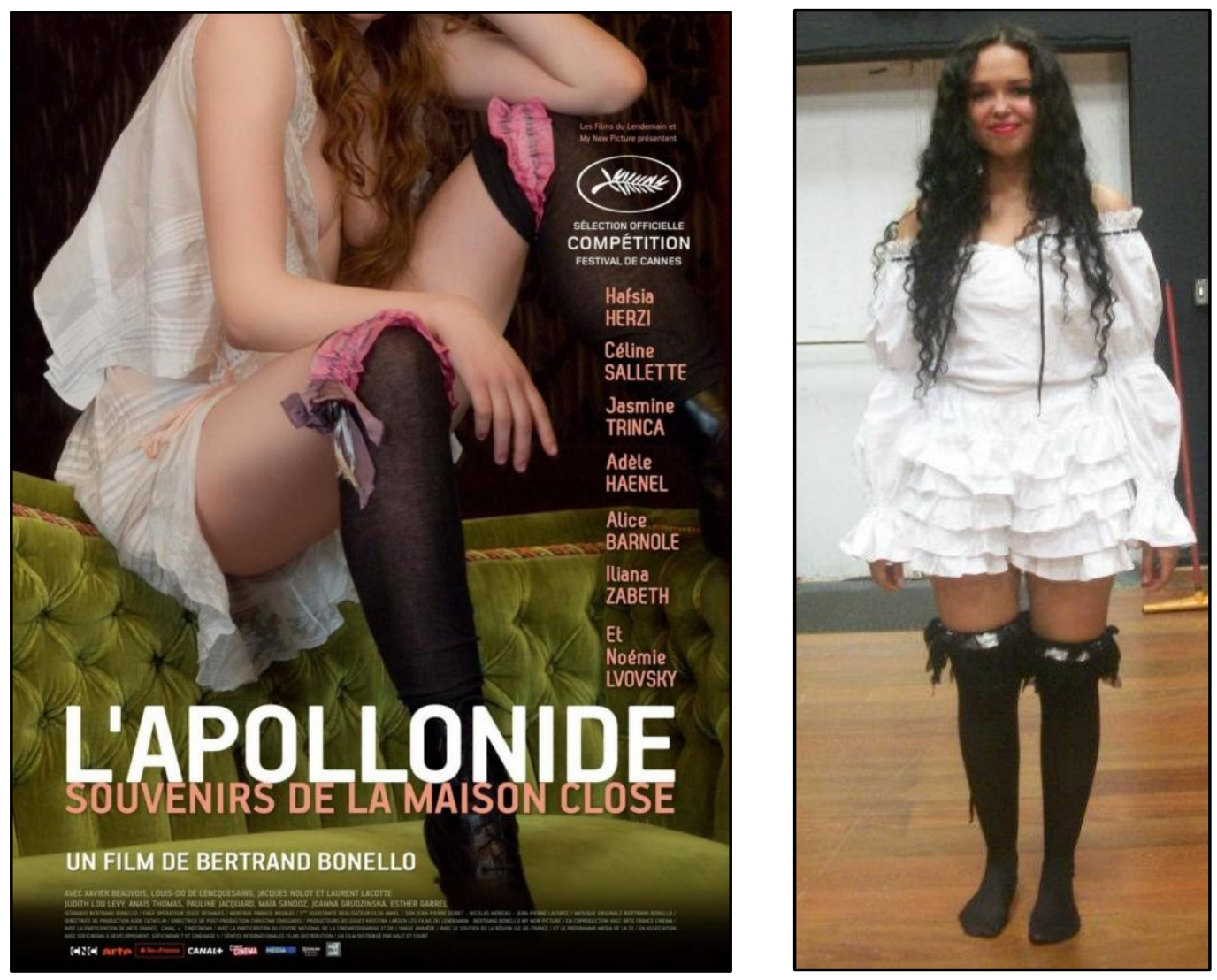

Anexo 29: O detalhe da liga - FIGURINO DE PATUSCA POR SILVANA DE CARVALHO.

A baixo, o espartilho underbust e as longas mangas
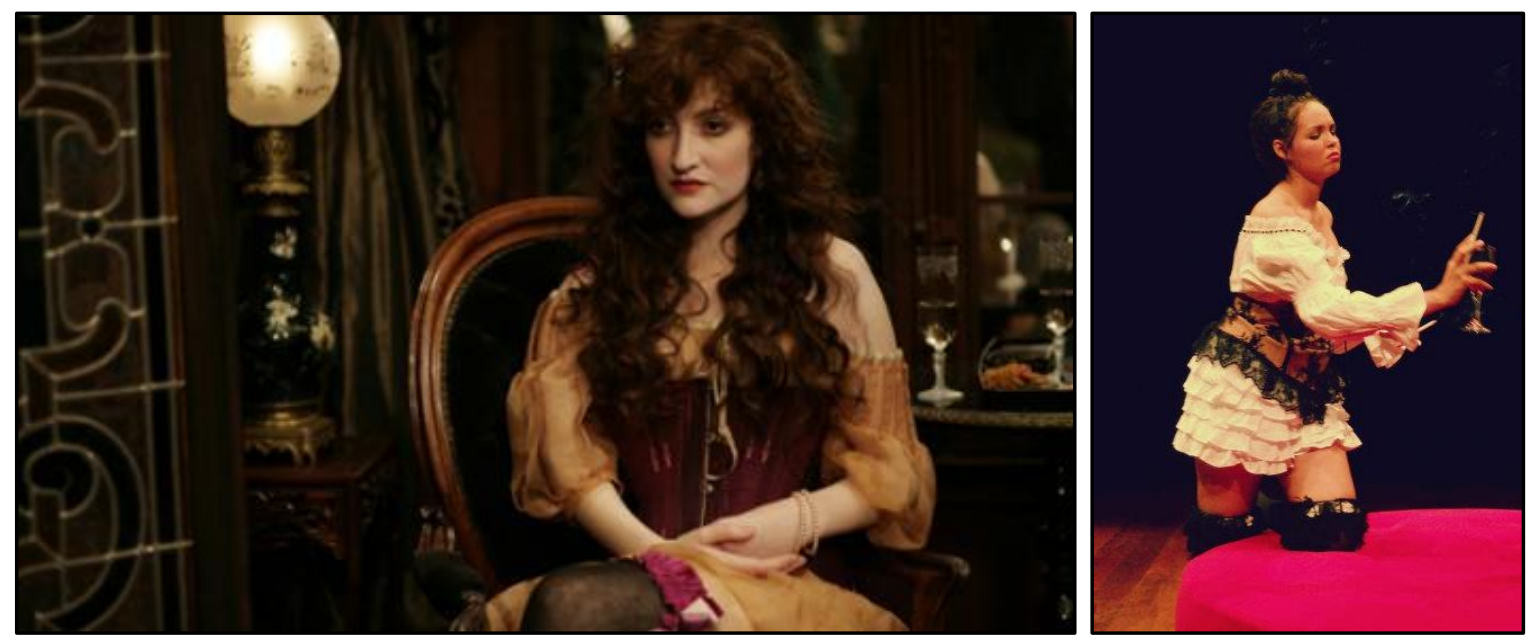


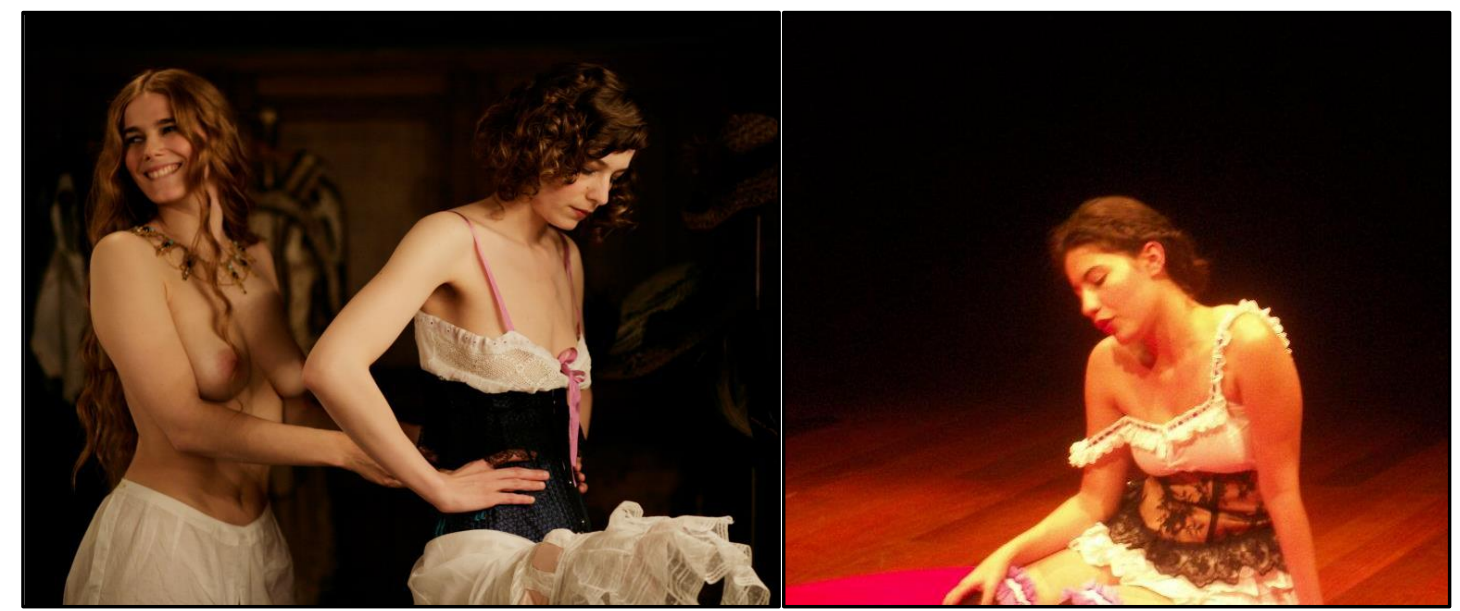

Anexo 30: Espartilho underbust e roupa de baixo como peça-única - FIGURINO DE BRENDA POR SILVANA DE CARVALHO
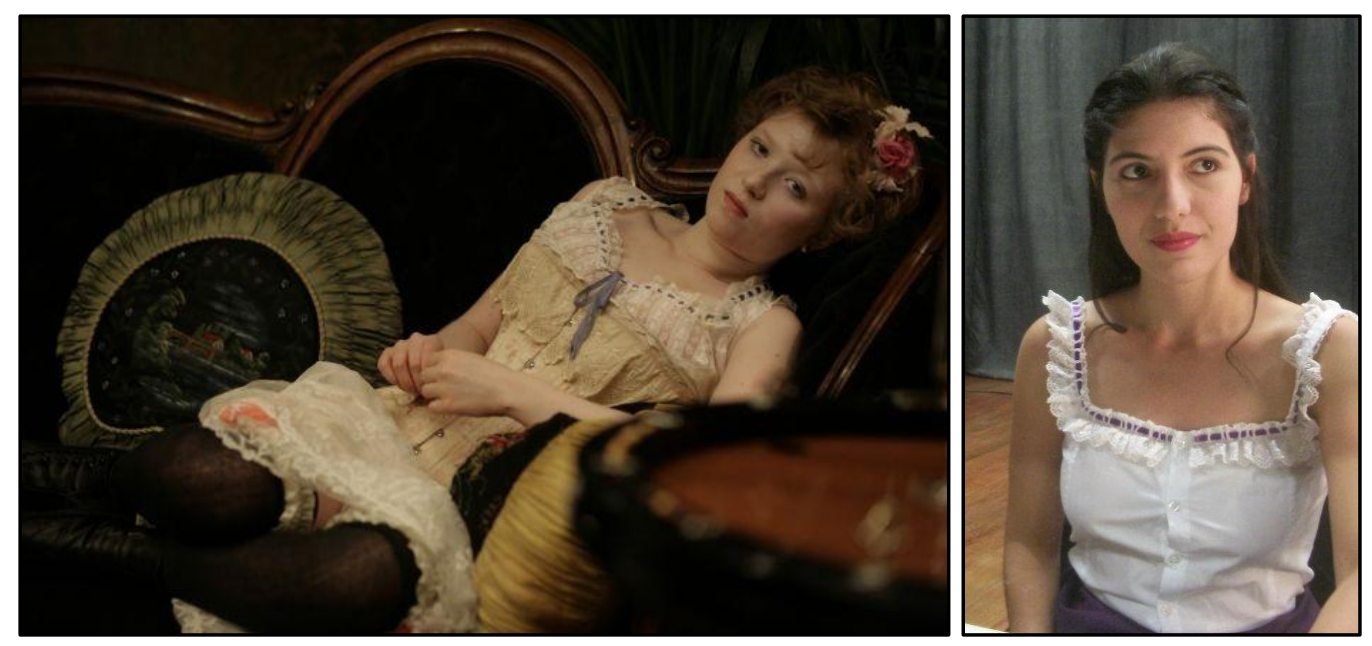

Anexo 31: Detalhe da alça com fitas - A ALIENAÇÃO DA ESPERA

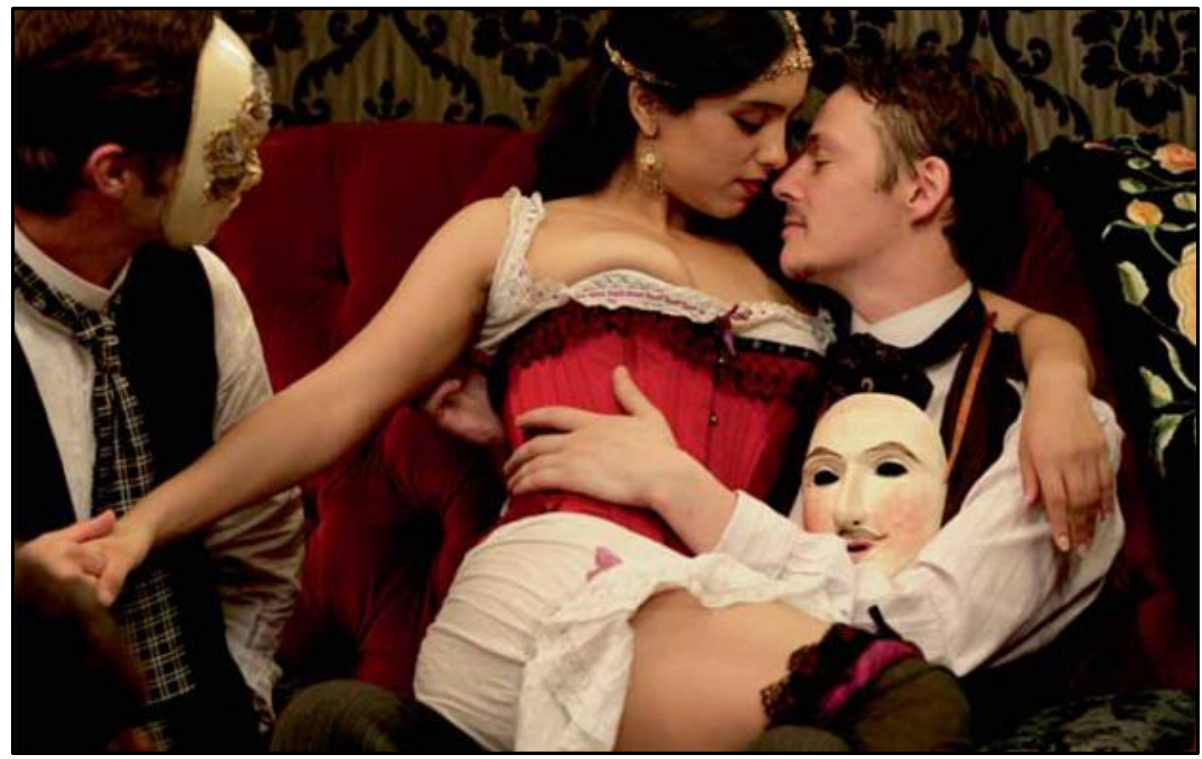

Anexo 32: Outra referência geral de L'Apollonide - OS TONS VERMELHOS EM PATUSCA 


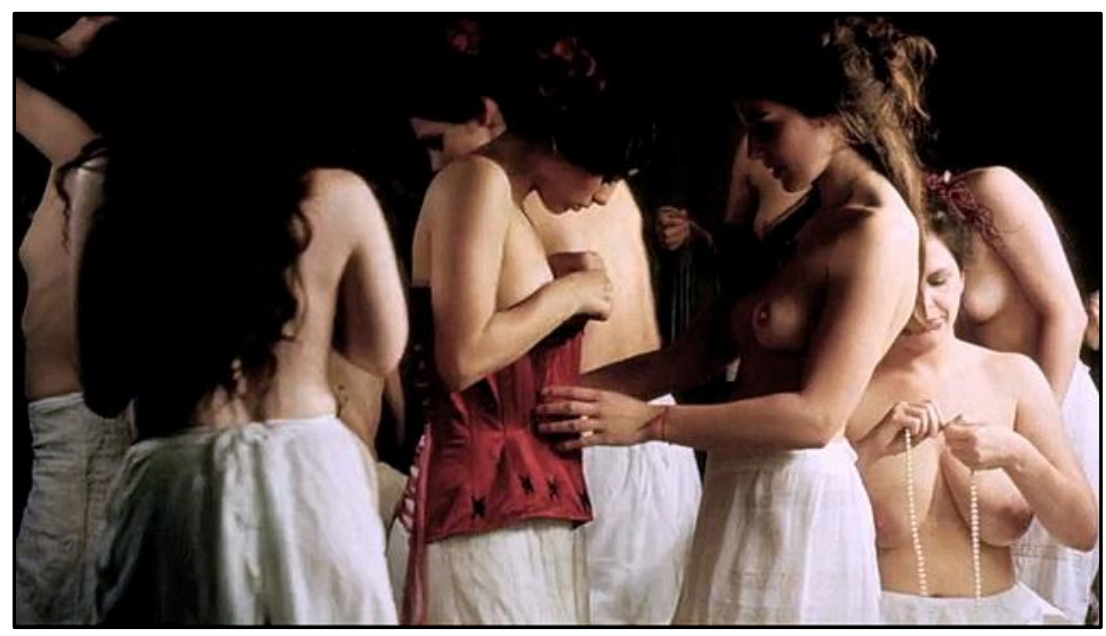

Anexo 33: Referência do filme L'Apollonide - O ESPARTILHO

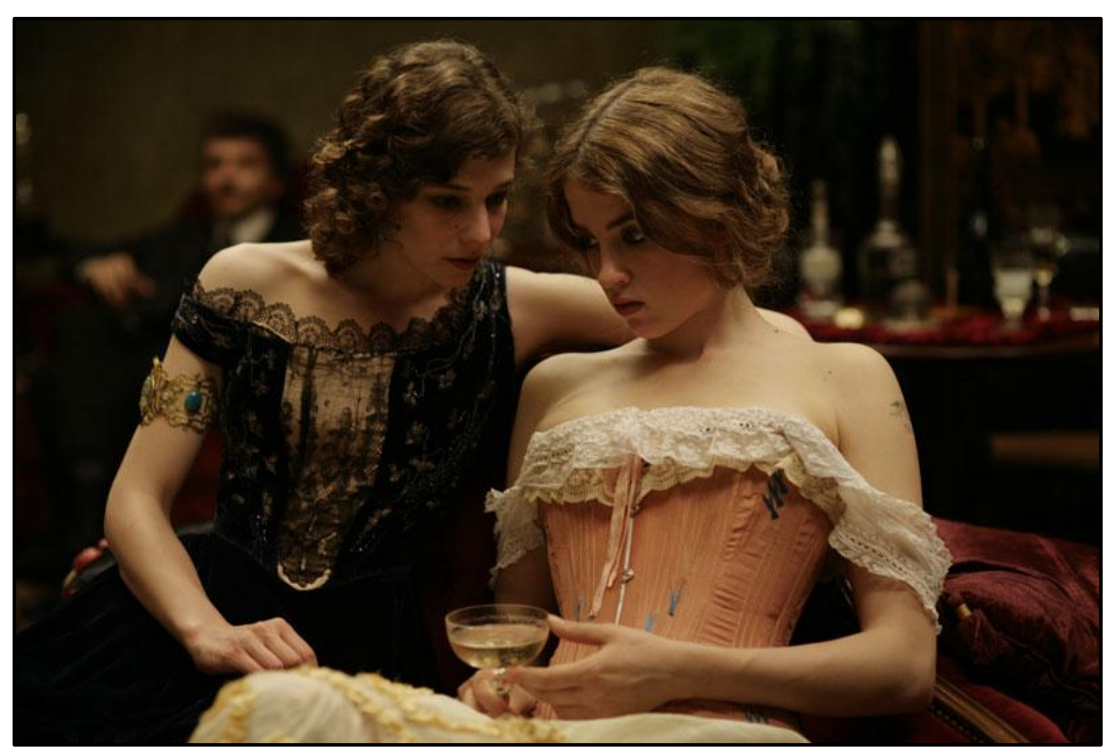

Anexo 34: A relação e a proximidade

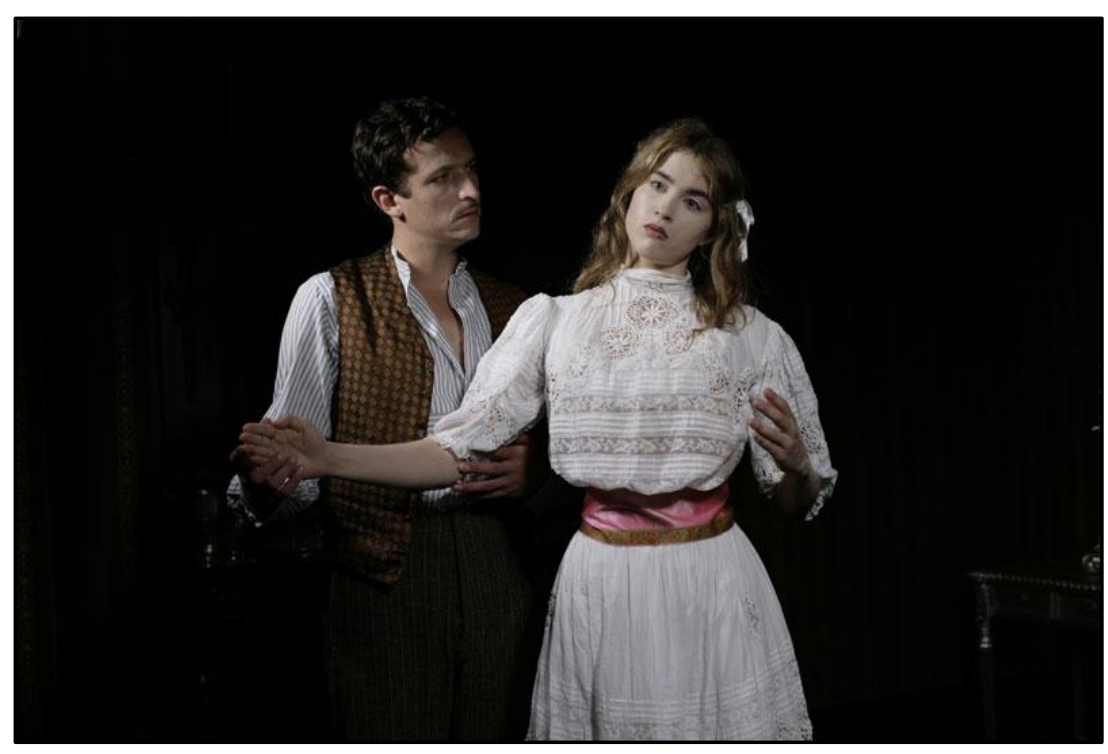

Anexo 35: A mulher-boneca, que já havia sido proposta e executada por Patusca, antes mesmo de assistirmos ao filme. 


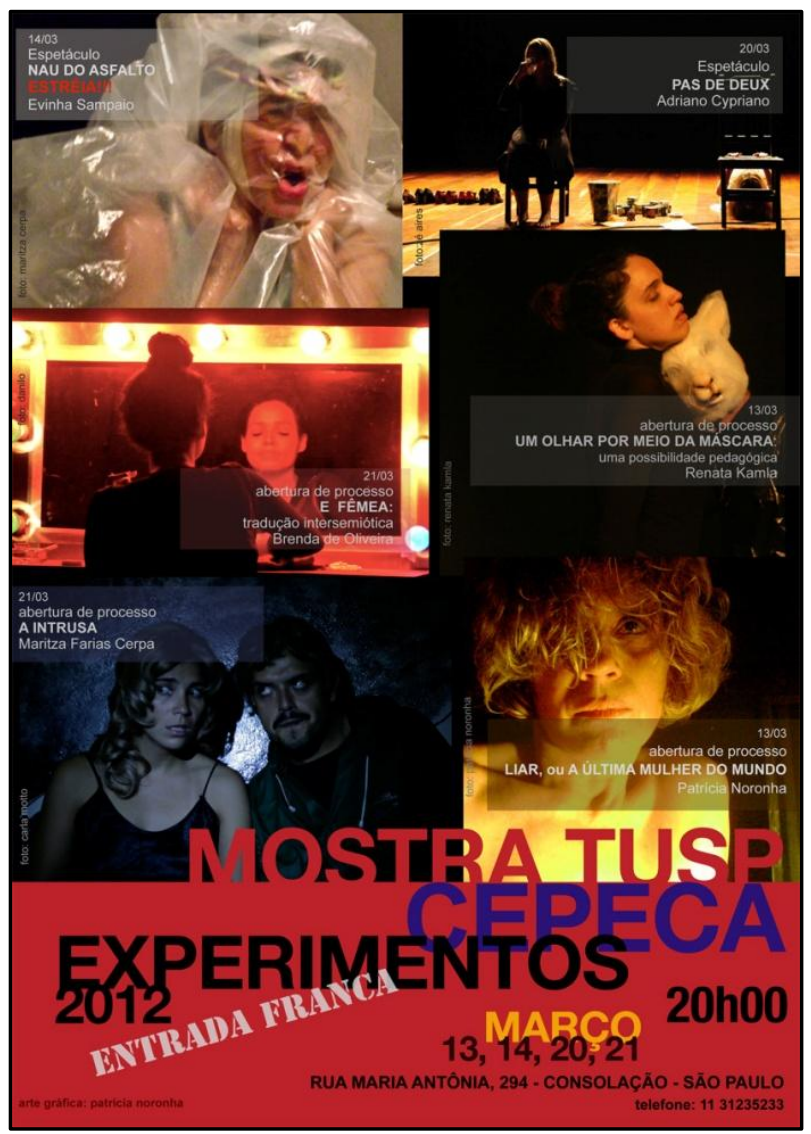

Anexo 36: Flyer do CEPECA para a Mostra Experimentos 2012 - ARTE DE PATRÍCIA NORONHA

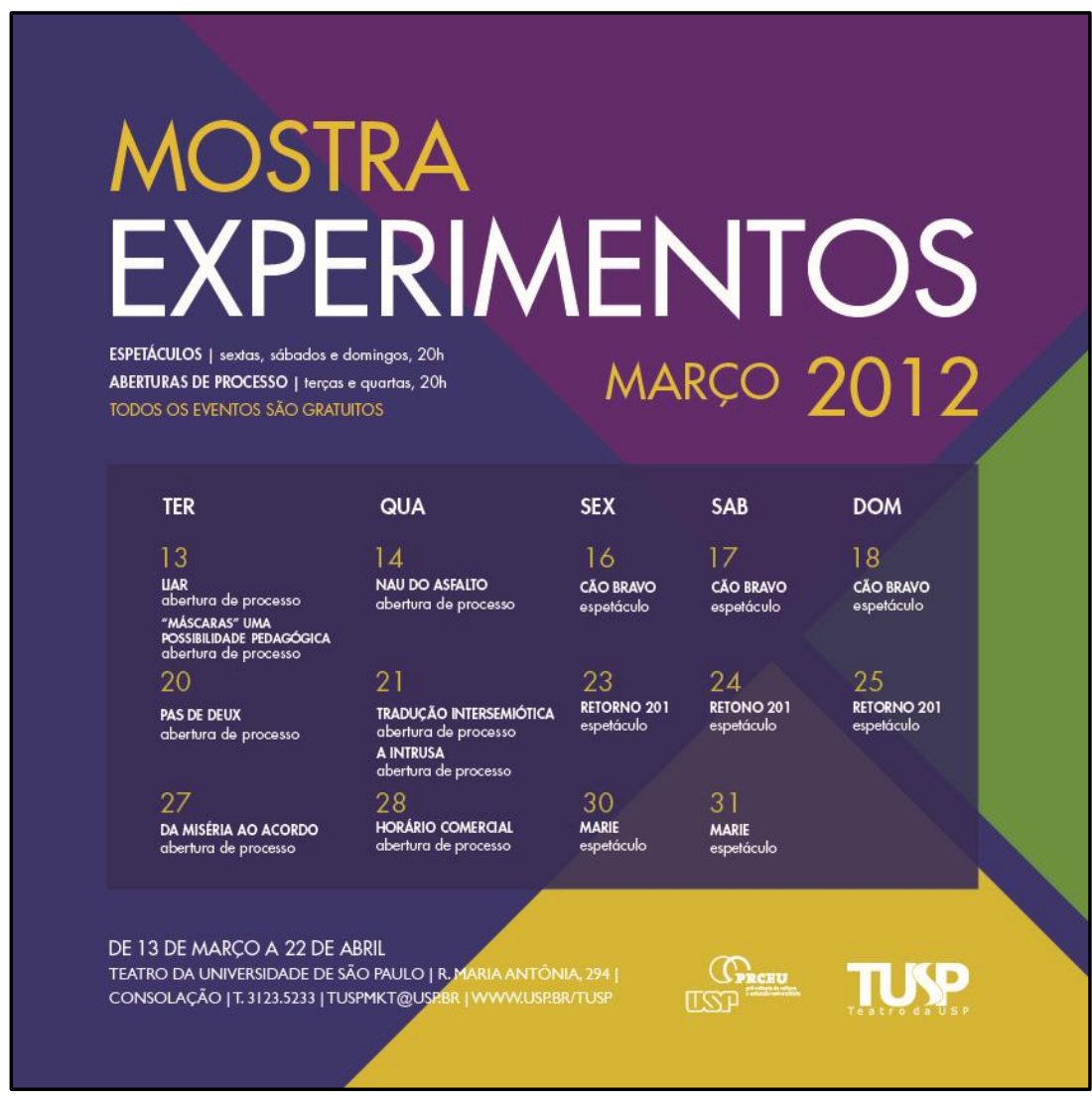

Anexo 37: Cartaz de divulgação da Mostra - TUSP 


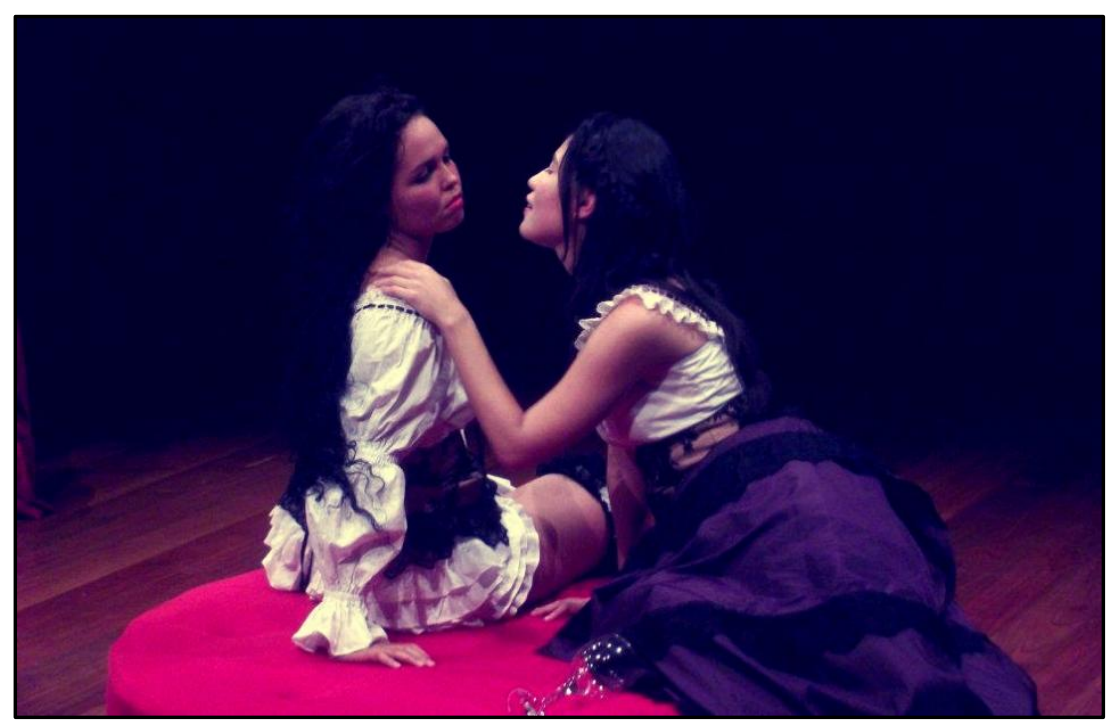

Anexo 38: Fotografia do Exercício na Mostra - MARGOT E NORAH

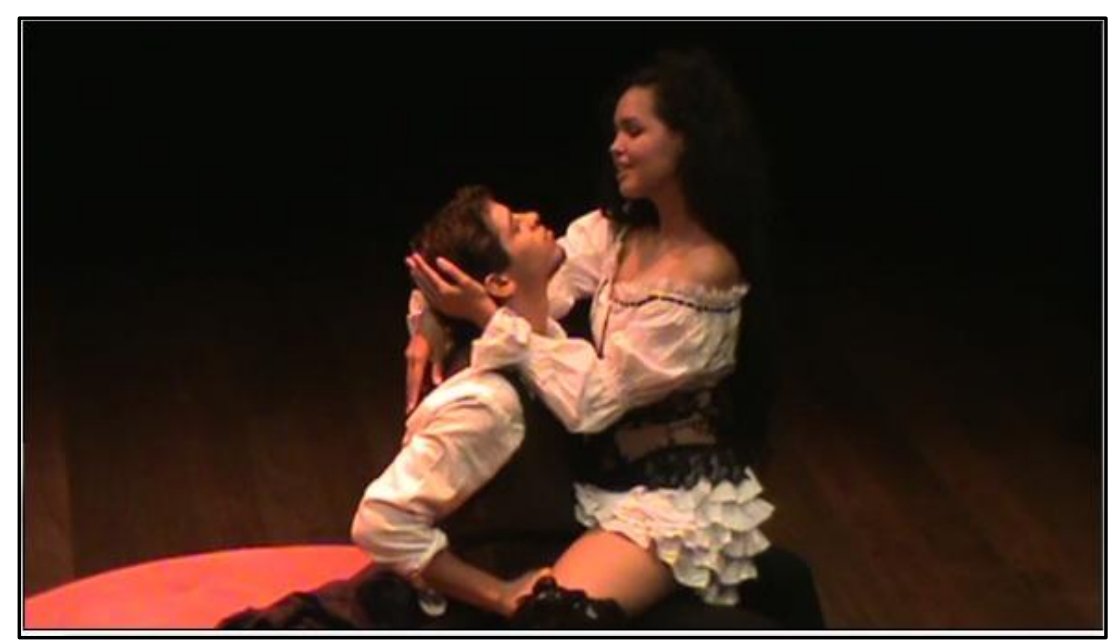

Anexo 39: Fotografia do Exercício na Mostra - PIERRE E MARGOT

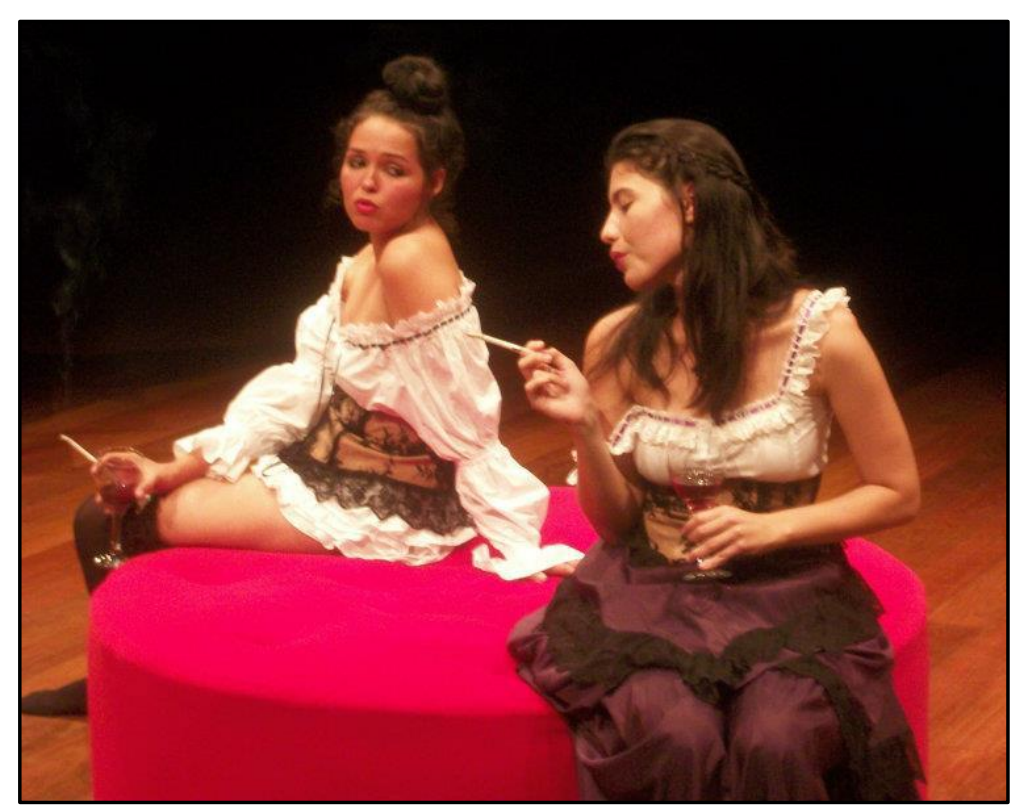

Anexo 40: Fotografia do Exercício na Mostra - MARGOT E NORAH II 


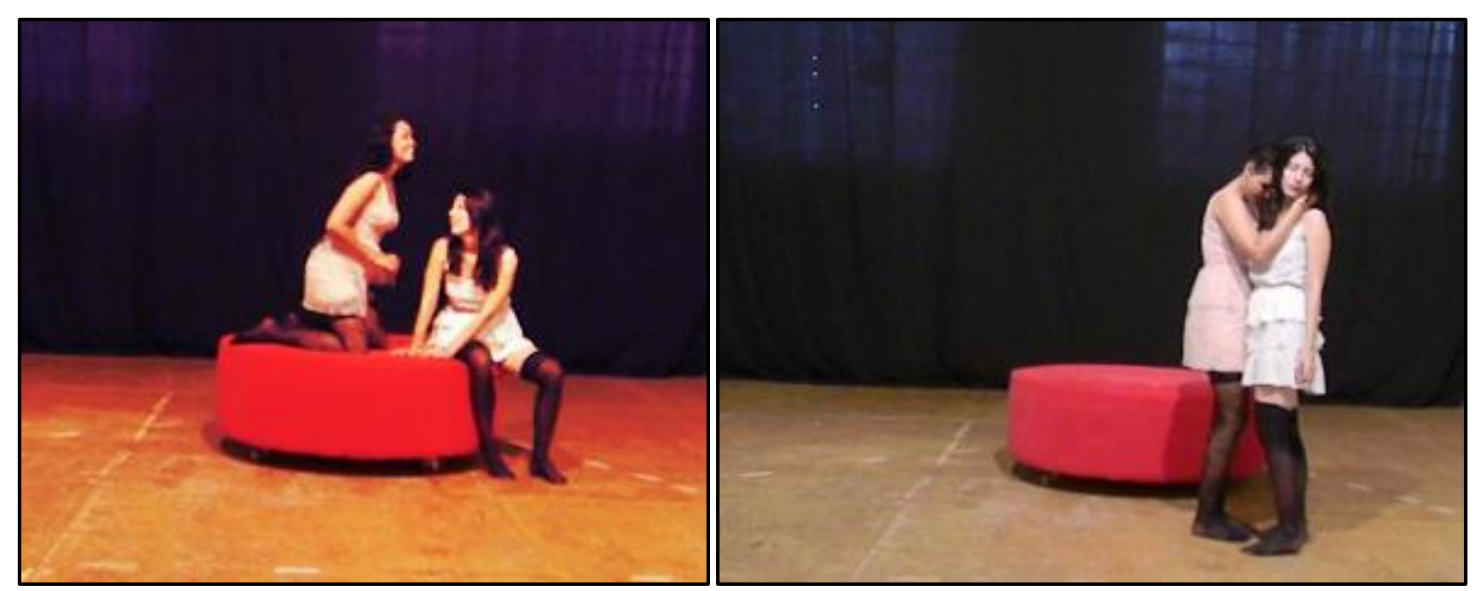

Anexo 41: Fotografia de ensaio para a Mostra - SALA DO CEPECA / ECA

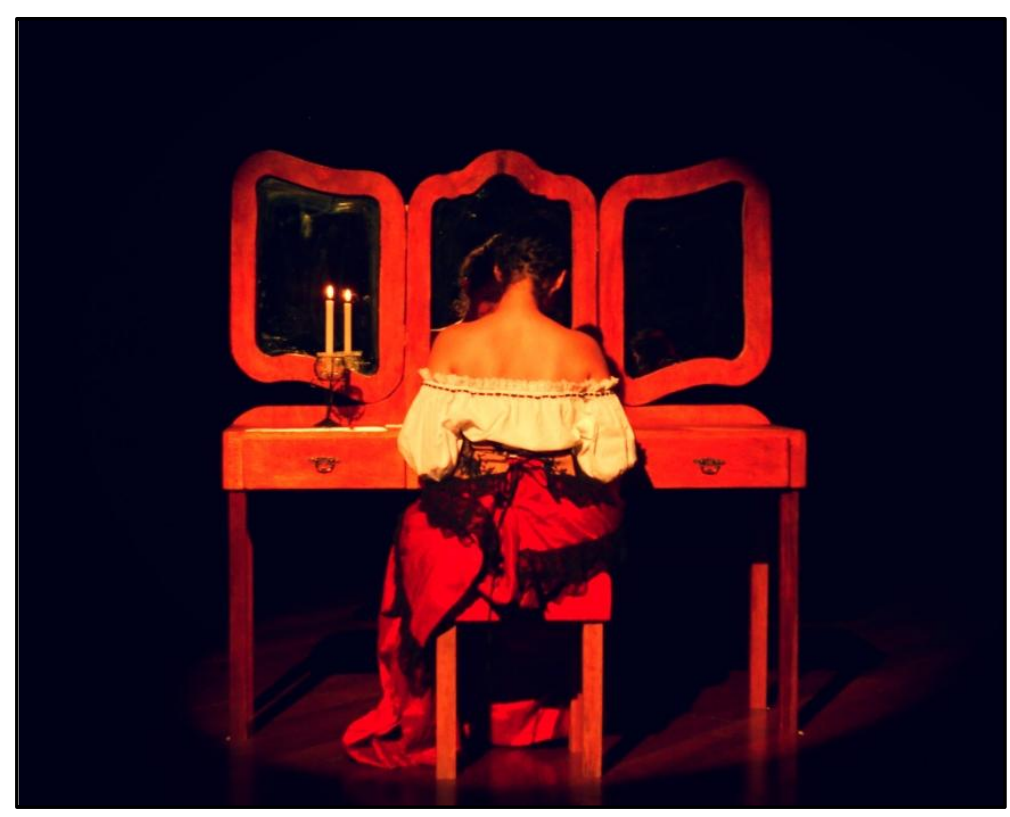

Anexo 42: Em cena, Patusca - MARGOT

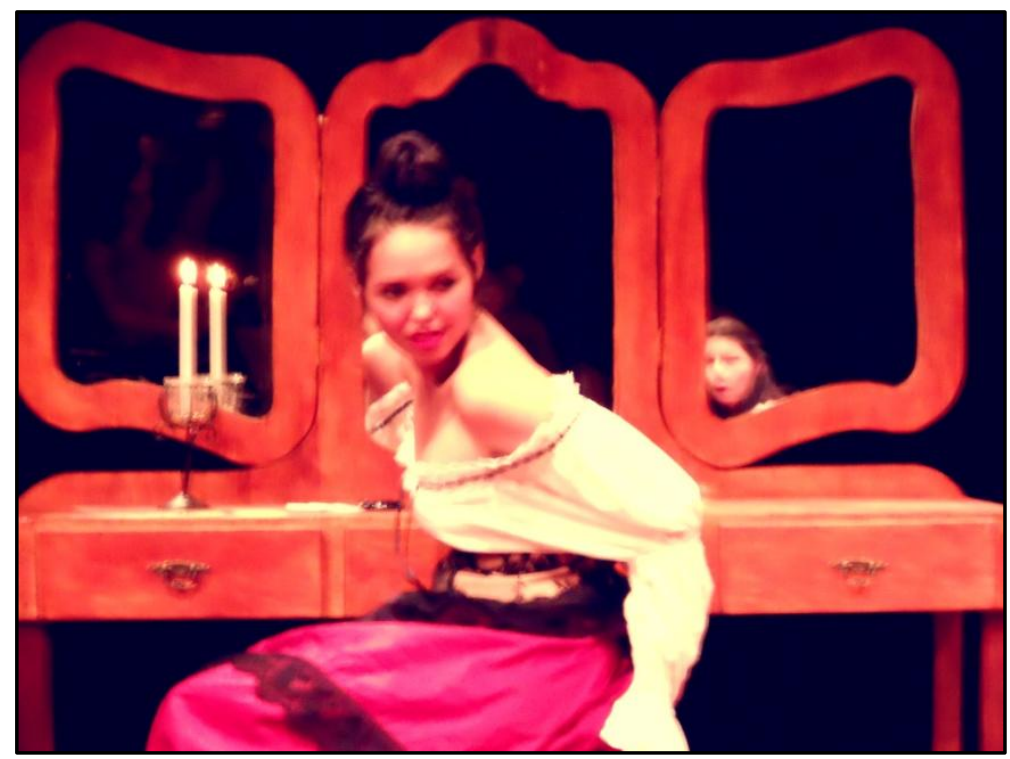

Anexo 43: Patusca como Margot - TUSP 


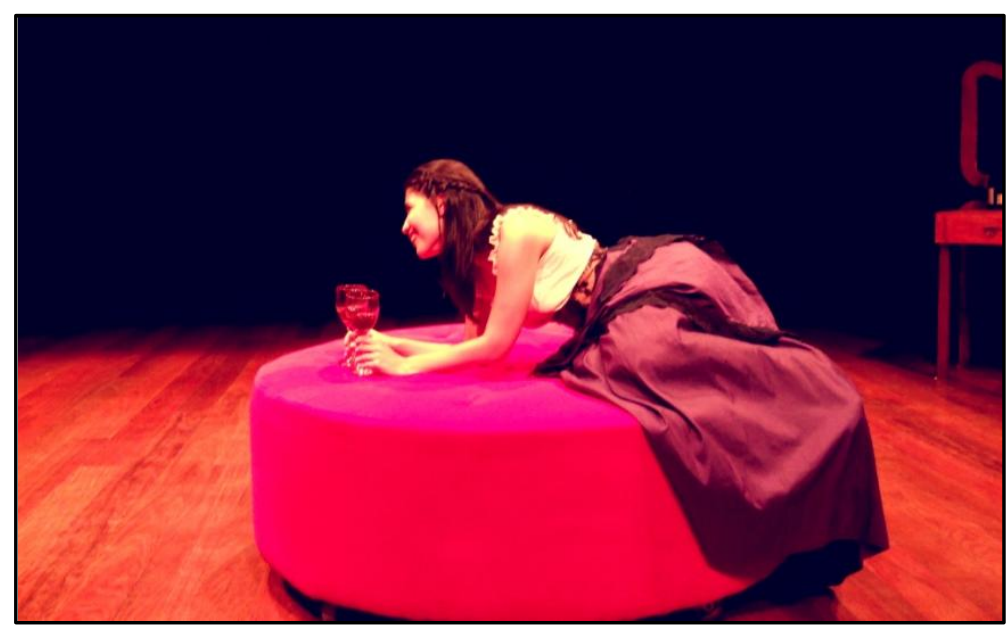

Anexo 44: Em cena, Brenda - NORAH

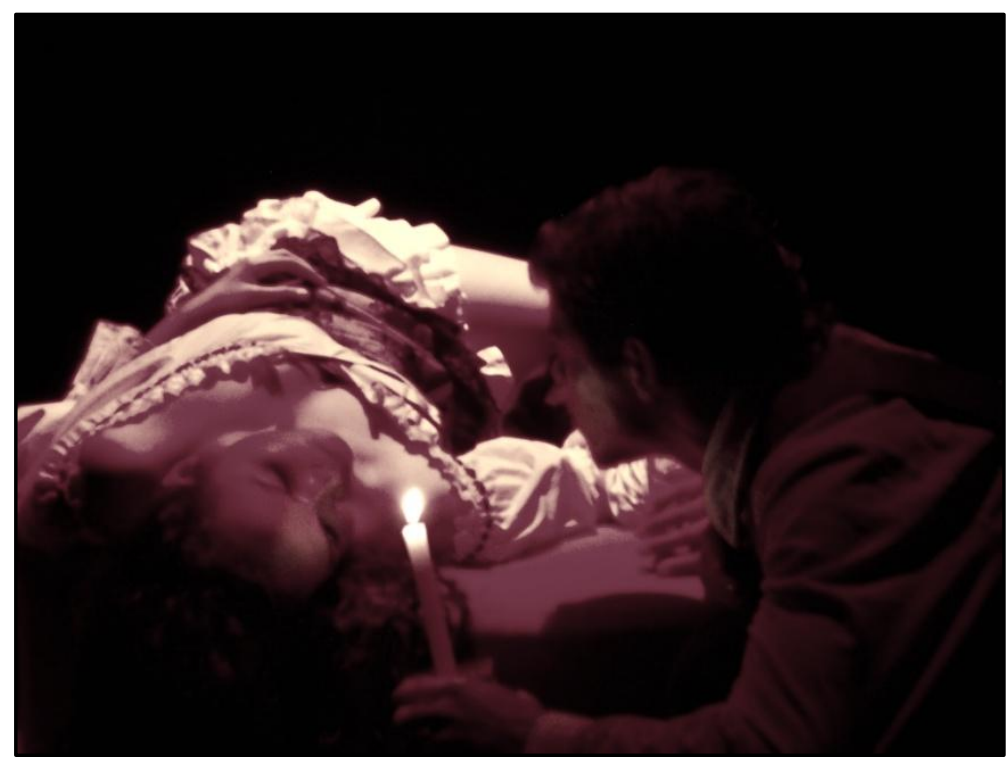

Anexo 45: Em cena, Elton Santos e Patusca - PIERRE E MARGOT

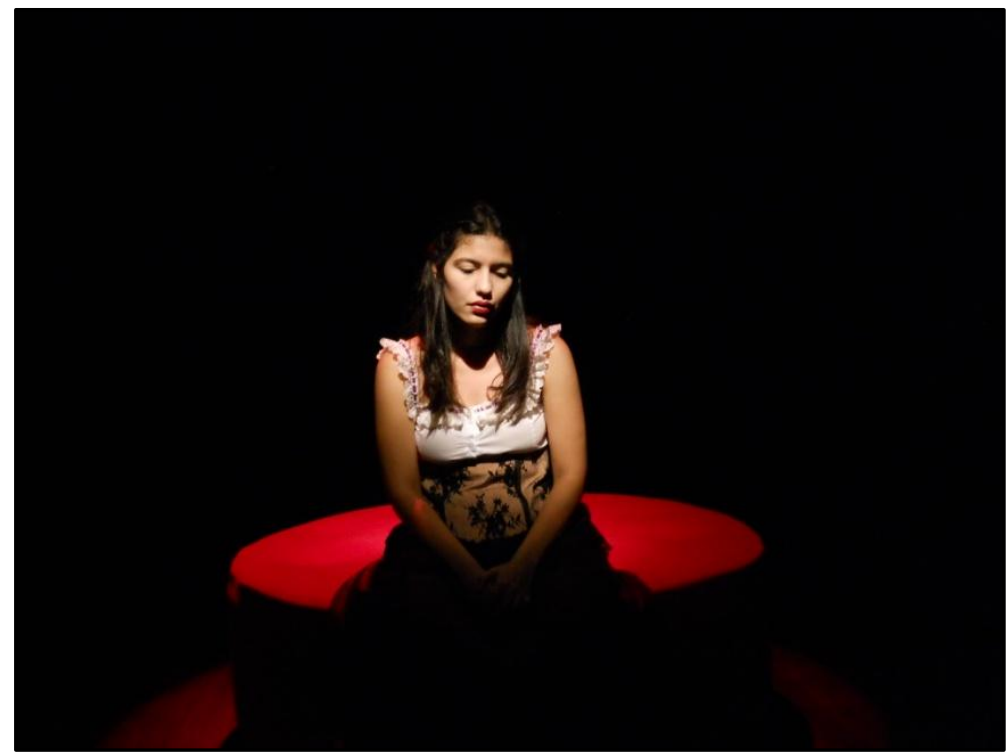

Anexo 46: Cena de abertura do exercício - ...E FÊMEA 


\section{...E Fêmea \\ texto \\ Patusca}

2012

São Paulo, 10 de janeiro de 2012.

(UM QUARTO DESORDENADO: VESTIDOS E OUTROS ARTIGOS FEMININOS, ESPALHADOS POR TODO O AMBIENTE ILUMINADO A MEIA LUZ).

\section{CENA I}

(Margot está sentada diante da penteadeira a se maquiar, ela percebe a presença de Norah pelo reflexo do espelho. Norah à passos lentos, para diante do divã e observa Margot que permanece de costas. O primeiro contato visual é através do espelho. Margot vira lentamente, olha-a, ainda sentada e diz:)

MARGOT: Então sentiste minha falta?

NORAH: Não, senti frio.

MARGOT: (levanta e caminha até Norah) E eu sou teu sol!

NORAH: O que passa? Fico ou não fico? (irritada)

MARGOT: Ficas, é óbvio que ficas.

(Inclinando-se para roçar os lábios no pescoço de Norah)

NORAH: Sem delírios por agora, Margot.

(Virando o rosto, porém sem afastar-se.)

MARGOT: Tu escolhes.

NORAH: Sem delírios.

MARGOT: Comeste? 
NORAH: Não.

MARGOT: Nem eu. (pausa)

MARGOT: Tens fome?

NORAH: Sempre.

MARGOT: E eu também.

(Margot toma do vestido e do carmim, oferecendo estes a Norah para que se prepare para sair).

NORAH: Não Margot, hoje não... Hoje... (Quase suplicante)

MARGOT: Sem delírios. (Seca)

\section{CENA II}

(Entram às gargalhadas, com uma garrafa de vinho nas mãos, que será consumida durante toda a cena,outra tonalidade, mas ainda assim meia luz)

NORAH: Não foi tão terrível assim.

MARGOT: Depois da terceira taça nunca é.

NORAH: Nunca vi homem mais ridículo.

MARGOT: Viste sim, tu que não te lembras.

NORAH: É... Creio que não me lembre, mesmo.

MARGOT: O que achaste do poeta?

NORAH: Caso para cinco taças. (às risadas)

MARGOT: Nunca se toma mais de três taças.

NORAH: Ora por que não?

MARGOT: Confunde os sentidos, perde-se o foco, o cliente e o borderô.

NORAH: O que achaste do poeta?

MARGOT: Consciente de mais, enfadonho em demasia.

NORAH: Consciente? Logo se via que estava ébrio.

MARGOT: Superficialmente ébrio, é desses homens que muito pensam e elucubram, acabam por nos cansar mais pelo emocional que pelo laboral.

NORAH: Há que se ter espírito pra esse tipo de homem, as prerrogativas da beleza nunca bastam para eles; vagam por aí, por becos e vielas fétidas, taciturnos, a cismar, procurando não sei o que, e encontrando o que há, e tão somente o que há, nada mais que isso.

MARGOT: E o que há?

NORAH: Nós e nossa fome, nosso frio, nossa dependência de ópio, nossas doenças e sonhos gangrenando há tanto tempo. E eles vagam por cá, creio eu, para procurar algo que lhes dê sentido ao que eles denominam uma existência vazia. (ela ascende um cigarro) Eles descem ao submundo com aquela ânsia frenética por dar sentido às suas próprias vidas. Eles usam o nosso vazio, o nosso não ter, para se preencher de algo que lhes falta. $\mathrm{O}$ que? Eu não sei.

MARGOT: E o que pode faltar a um janota?

NORAH: O poeta não é janota? 
MARGOT: É sim. Rico, muito rico, de família nobre.

NORAH: Isso sim, mas não é janota. Não tem a imbecilidade da juventude, não é raso, é desses homens cheios dessa literatura acadêmica. Eles se revoltam contra ela, repudiam-na, mas mesmo assim ficam infectos dela, eternamente, vai entender.

MARGOT: (apontando um cigarro para que Norah o ascenda) Crês que o poeta seja desses homens que ingressaram à cátedra?

NORAH: Ingressou e abandonou como todos os revoltados e incompreendidos que nela ingressam.

MARGOT: Não tenho espírito para esses homens cheios de intimismos e devaneios.

NORAH: Ele se agradou de ti.

MARGOT: É muito mais fácil e possível lidar com aquelas bestas-feras corpulentas, que nos procuram cheios de uma vontade agressiva, os sentidos a flor da pele, com os desejos mais obsceno. Eles não têm 'quês' nem 'por quês', eles só querem uma coisa, e eu sempre sei o que é.

NORAH: Viu algo em ti.

MARGOT: Nada mais enfadonho do que esses pensadores modernos, irritantemente entediados da vida, absortos em pensamentos que sequer lhes pertencem, ávidos por descobrir algo que nem eles próprios sabem o que é, apáticos, lacônicos, morgados.

NORAH: Vai voltar pra te ver.

MARGOT: (austera)E vai devorar-me se vier a ter comigo, tu bem sabes que não tenho talento algum para lidar com a subjetividade impertinente desses intimistas.

NORAH: (ás risadas) Escolhes. Estás a escolher?

MARGOT: (de pé no divã) Sabes do que eu gosto? Homens de farda. Adoro homens de farda, mas não todos, gosto dos tenentes, dos aspirantes, daqueles jovenzinhos tolos, recém-incorporados. (às gargalhadas) Nada dá mais prazer do que deitar com esses soldados rasos, que chegam exasperados após meses de campanha; marinheiros enfurecidos que passaram de um continente ao outro tendo apenas céu e mar diante dos olhos.

NORAH: Então não gostas de farda, gostas de meninos trajando farda.

MARGOT: Não gosto mesmo dos generais, dos almirantes, prefiro os recrutas e grumetes.

NORAH: (ascende um cigarro) Ah, os generais tem seus charmes. Além do que, se o que te interessa são meninos, há uma porção deles por aí.

MARGOT: Porção de vagabundos. A farda da um ar de benevolência, são meninos encaminhados, não os marginais que por cá andam.

NORAH: São marginais fardados, sua tola.

MARGOT: Que seja. Mil vezes essas fardas de ombros de lapelas quase nuas, do que o peito repleto de medalhas. Que quanto mais medalhas e mais patentes 
mais barriga, mais cansaço, mais esforço e menos cabelo, menos disposição, menos prazer...

NORAH: (Austera) Mais dinheiro e logo mais lenha, pão e ópio.

(cessão as risada)

MARGOT: Apesar da boa noite estás amarga.

NORAH: Estou cansada. Estou que não suporto mais as privações, a falta, a impossibilidade. Ter de sair todas as noites para buscar quem me pague o jantar, ter de dormir entre tantos para me aplacar o frio. Me enoja a inspeção sanitária, ver aqueles homens de branco obrigando-me a deitar e a exibir-me a eles, com aqueles olhares gelados sempre à eminente possibilidade de estar ou não doente, desdita mais podre, diagnosticada por aqueles vermes de jaleco, igualmente podres, que tenho pra mim que os próprios colocam a doença em nós. E que fim mais repulsivo. Ter de ver outras sendo recolhidas por conta da moléstia. Tenho nojo delas, mas hoje são elas, amanhã poderei ser eu; eu doente com aquele cancro a me corroer inteira a começar pelas partes, me consumindo de febres e ulcerações pútridas, me decompondo o corpo ainda em vida, pulsando em mil agonias...

MARGOT: (interrompe-a irritada)Eu sei o que é isso. Eu também passo pela inspeção todas as semanas.

NORAH: Então não ignoras o fato de que o poeta vai voltar e te procurar.

MARGOT: O que estás a pensar, Norah? Achas que vai me tirar daqui? Achas que vai se encantar comigo de forma tal que me levará a uma casa de campo onde terei janelas com belos gerânios, chás de laranjeira e carvalhos empilhados ao lado da lareira de mármore. Que romântica estais a me sair, Norah.

NORAH: Sabes o lugar que ocupas e ainda assim te colocas numa posição de intocável, é quase incrível a tua imbecilidade.

MARGOT: Nem que fosse. Pensas que engana a ti mesma? Julgas que perdes a consciência do que somos nós: pérfidas, gente de má cepa; está em nós, isso nos faz, somos assim, feitas desse limbo. Sabemos muito bem o que nos espera, e não há nada, muito menos um poeta cismado, que nos tire daqui, porque aqui nascemos Norah, e gente como nós, ouves bem (segura-lhe o queixo com força), gente como nós não sabe ser outra coisa senão isso que somos: marginais, viciadas, prostitutas, gatas de rua; e curiosamente é tão somente aqui que sabemos viver, sob essa pressão, de correr de quem devemos, de nos esconder da vigilância, de roubar a quem nos serve, de enganar a quem nos procura. É isso que somo e é isso o que fazemos, e por isso é aqui, e tão somente aqui, que sabemos viver, que fora daqui não há nada para nós, e se daqui sairmos, aqui voltaremos a cada vez que formos escorraçadas de outros lugares a que não fazemos jus.

NORAH: Que fatalista estás me saindo. 
MARGOT: Somos assim, e não tente crer que não, está em nós, somos nós.

NORAH: Como tu mesma já o disseste, nós sabemos o fim inexorável que nos espera. O fim Margot, não o caminho. Se sabes que vais amargar, por que não gozar por agora? Tua arrogância e pedância a nada te levará, assim como se fores dócil e cândida em demasia, isso é certo. Mas se souberes ser fêmea, se souberes usufruir desse ardil que adorna o nosso sexo, poderás gozar e muito.

MARGOT: Esqueces que jantamos hoje porque exigi que saíssemos? Eu exigi! E por isso bebemos e comemos muito bem. Que se fosse por ti, cá ficaríamos.

NORAH: Pão nosso de cada dia. (cínica)

MARGOT: Eis nossa vida, a vida de toda mulher que é como nós.

NORAH: E se quisermos mais que pão? E se quisermos brioche, carpaccio, brie. MARGOT: Nem sempre se quer.

NORAH: Sempre se quer e nem sempre se pode, mas nós podemos, ainda, por enquanto.

MARGOT: Mas não quero.

NORAH: Mentira! Blagué! Blasé! Se tua insolência ao menos te rendesse prazeres, mas não, te colocas num pleito como se fosses intocável por que possuis um único trunfo, efêmero e traiçoeiro: a beleza. E o que é a tua beleza daqui a um tempo? A beleza é uma doença que se trata até que se cure e desapareça, e essa doença sempre tem cura, pois ela sempre desaparece. Por causa dela hoje o teu desdém soa como coquetismo, capricho felino, o que pode ser um atrativo a mais para os mais vaidosos e obstinados, atiça o desejo de posse. Mas até quando? Até quando, Margot? Até o quanto durar a tua beleza, e daí o teu desdém não passará de inconveniente ridículo, desdenhada serás tu, inconveniente será a tua visão para aqueles que descem por cá em busca de prazeres, de se embriagar das risadas, dos espetáculos, das bebidas e das belas mulheres que por aqui andam. E em meio a todas essas distrações picantes, haverá tu, a vagar, esmolando pelos cantos e vielas, tal como os pedintes, os viciados, as velhas a vender rapé às portas e entradas dos cabarés onde, um dia, tu pisaste como ninfa. A tua imagem será como uma nodoa num belo espartilho de seda.

MARGOT: Eu sei muito bem o que me espera.

NORAH: Sabes o que te espera, mas não esperas como deverias, a gozar de todos os prazeres que a tua juventude pode conceder. Margot, o que é o outono de uma mulher sem o bálsamo dessas lembranças de prazer? Que a velhice por si só já é amarga por de mais, e as lembranças são a nossa morfina para bem suportar o que não há como evitar.

MARGOT: (agressiva) Tratas a ti e a mim como se fossemos frutas num cesto a perecer, como se fossemos dessas flores em ramalhetes que sobrevivem por 
míseros 5 dias.

NORAH: E não somos?

MARGOT: (reflexiva) Prefiro não pensar, prefiro ignorar, não ver, que não saber me resguarda, faz com que doa menos, eu vivo um dia de cada vez, um instante de cada vez, e os próprios acontecimentos me conduzem, eu não preciso estar ciente de nada.

NORAH: Mas estás. E sabes que estás, queres ignorar que estás ciente de tudo, mas apenas queres, não ignoras, apenas desejas não saber, mas sabes, tu bem sabes Margot.

(pausa)

NORAH: Sou bonita não sou, Margot? Sou muito bonita. Olha para mim. (Em frente ao espelho).

MARGOT: Linda! (sorrindo com admiração)

NORAH: (em frente ao espelho) O tônus da minha pele (tocando o rosto), meu dorso (tocando-se), meu colo firme (sempre se tocando). (virando-se para Margot, que lhe sorri durante toda a cena) E a minha voz, Margot? Não é linda a minha voz quando canto?(ela inicia a canção de Ângela em 'Uma Mulher é Uma Mulher")

MARGOT: Adoro quando catas (sorrindo).

NORAH: (Salta no divã continua a cantar) E quando danço naquele cabaré lotado, já viste como os homens ficam?

MARGOT: Ficam loucos pelas tuas pernas... Ficam loucos por ti inteira.

(Entra sonoplastia - Guilt - Norah dança enquanto Margot a admira. A música cessa aos poucos.)

NORAH: E nem desconfiam que eu já tenho 23... E tu, Margot? Quantos tem? (menos esfuziante que antes)

MARGOT: Sabes muito bem que tenho 21. (séria)

NORAH: Viste a moça nova? Tem 16, assim como quando cheguei, passa tão rápido que a gente nem percebe, só sente os efeitos. Há tão pouco tempo eu tive 21 que às vezes me esqueço que tenho 23 , mas mesmo que me esqueça são 23 , nunca mais tornarão a ser 21 , e daí só por diante.

MARGOT: Mas afinal que diabos queres com tudo isso?(irritada)

NORAH: Quero que reflitas, reflitas muito bem acerca de tudo que te disse. Querida Margot, sabes que te quero muito bem, há quanto tempo que somos como irmãs, hem? Minha irmãzinha, minha querida irmãzinha (Inclinando-se para beijar-lhe o pescoço). 
MARGOT: Sem delírios, Norah. Sem delírios (Virando o rosto, porém sem afastarse).

\section{CENA III}

(Cena mais iluminada. Pierre está sentado no divã e Margot sentada em um cadeira a sua frente, eles permanecem calados por alguns segundos até que Margor quebre o silêncio)

MARGOT: Antes de tudo, exijo que saibas que a quero muito bem.

PIERRE: Oh! Eu nunca duvidei.

MARGOT: Até agora não sei o que queres ao certo.

PIERRE: Talvez sofra de algum tipo de parafilia não diagnosticada.

MARGOT: Duvido muito. (reflexiva enquanto o observa) És tão estranho! Nunca me quiseste! Nunca quiseste me tocar (-pausa- ela o observa em silêncio, ele sempre a observando) Nunca me quiseste? Nunca quiseste me tocar? (ela se inclina para ele) Tens vontade de me beijar na boca, Pierre? (fechando os olhos enquanto espera que ele a beije. Ele imóvel, próximo aos lábios dela, porém, permanece imóvel).(-pausaela abre os olhos mantém a proximidade e fala olhando para ele) Não tens vontade de me beijar por que sou uma prostituta ou por que sou uma mulher?

PIERRE: Porque és Margot! (Olhando nos olhos dela, sem desviar o rosto)

MARGOT: (Ela levanta e caminha pelo ambiente) Sempre ficamos aqui há horas, não queres me tocar, nem me olhar despida, nada fazemos a não ser ficarmos calados. (Esfuziante e curiosa) Tens vontade de me bater?

PIERRE: Não. (sempre austero)

MARGOT: (ela gira em volta dele) Tens vontade de mijar em mim, Pierre?

PIERRE: Não.

MARGOT: Se quiseres pode gozar na minha cara, podes gozar dentro da minha boca.

(ele calado, impassível)

MARGOT: Queres que introduza coisas em ti, um dedo ou dois? Uma banana? PIERRE: Quanta gentileza, Margot. (impassível)

MARGOT: (reflexiva) Muito estranho! (às risadas) Quando cheguei aqui, o meu sonho era encontrar um cliente tal qual tu. Eu tinha tanto medo dos homens, mais que isso, eu tinha nojo; nojo de como me olhavam, de ver que tinham vontade de me tocar inteira. Na primeira vez eu desejei tanto que meu primeiro homem fosse um que não me quisesse tocar, eu sonhava que seria um homem 
bom e gentil, que passaria 40 minutos trancafiado comigo em silêncio, sem me tocar, sem nem me olhar; ele esperaria dar o tempo, me pagaria regiamente, iria embora e voltaria todas as noites seguintes, e sempre aconteceria a mesma coisa para sempre, até que chegasse o dia em que eu fosse embora daqui.

PIERRE: E como foi?

MARGOT: Um porco a chafurdar encima de mim, um homem asqueroso, me chamava de pombinha, (arremedando o homem) pombinha. Nem de pombas eu gosto. Babou-me inteira, uma saliva fétida, fétido ele inteiro, suarento, insuportável. Tive a impressão que durou uma eternidade, depois me disseram que não passou de 20 minutos. (pausa) Depois dele veio outro, e outro e outro, uns piores que os outros, são tantos e tantas vezes, que depois nem se percebe mais, depois se passa a considerar que não são tão maus assim. (reflexiva) Desenvolve-se uma habilidade de lidar com todos eles e todas as situações, cada cliente é único e curiosamente todos eles querem a mesma coisa, só que de formas diferentes, todos querem se preencher de algo que lhes dê prazer, nem sempre o mesmo prazer, mas ainda assim prazer. Com o tempo se aprende tanto que somos capazes de crer que nascemos com um talento nato, um talento congênito de dar prazer para todos esses homens, chegando-se a acreditar que nascemos para isso e que não há mais nada que saibamos fazer de melhor, ficamos aqui para sempre, resignadas de saber que querendo ou não é esse o nosso lugar... (sentando no seu colo de frente, colocando-o entre as suas pernas, envolvendo o seu pescoço com os braços, ele imóvel e ela a olhar nos seu olhos) Tu chegaste muito tarde Pierre.

PIERRE: Cheguei. (olhando nos olhos dela)

MARGOT: Tão tarde que agora és tu quem me assusta, o homem que eu sonhei para meu primeiro cliente.

(-pausa- Olha-se em silêncio)

MARGOT: (-Quebra- esfuziante, mas ela permanece em seu colo durante toda a cena) E eu já estive com outros homens que não me quiseram tocar: Artistas, pintores, escultores, e até atores e poetas; ah, mas esses me tocaram, alguns pintores também. Mas artistas são muito temperamentais, vaidosos em demasia, possuem uma alma muito feminina. Agora tu não Pierre, eu nunca sei o que tu queres. Não tenho espírito para homens tão excêntricos quanto tu, me apetece algo mais vulgar. (reflexiva) Eu nunca sei o que tu queres Pierre. O que tu queres?

PIERRE: Norah. 
PARGOT: Poderias tê-la independente de mim.

PIERRE: Não quero que me veja como a um cliente vulgar ou como um janota apaixonado.

MARGOT: Quer que eu fale bem de si para ela?

PIERRE: Quero que fale de mim.

MARGOT: Falarei bem... Bem mal.(só agora ela levante de deu colo)

PIERRE: Sentirás minha falta?

MARGOT: Sentirei falta do borderô. (pela primeira vez ele sorri)

\section{CENA IV}

(Cena iluminada Norah entra e encontra Margot a maquiar-se, o primeiro contato visual é pelo reflexo do espelho)

NORAH: Dormi com o poeta!

(Margot parada continua a observá-la pelo reflexo do espelho)

NORAH: Que homem!

(pausa)

NORAH: Que homem mais insuportável, Margot!

MARGOT: (às gargalhada) Estás a escolher?

NORAH: Não estou a escolher, estou a reclamar. Ele declama em plena foda. ( $a$ arremedá-lo e a movimentar-se como quem faz alusão a uma relação sexual) Gostaria de encontra-te, tuas mãos trementes se desmanchariam na sonoridade dos meus ditos, faria dos teus olhos luz, da tua boca um eco, nos teu ouvidos eu falaria de amigos...

MARGOT: E tu decoraste o verso.

NORAH: Ele me fez o declamar por 17 vezes.

(Margot a rir freneticamente)

NORAH: Eis-me de quatro a segurar um papel, tendo de equilibrar-me com uma única mão enquanto ele repetia versos outros que me confundiam ainda mais, falava-se tudo e nada ao mesmo tempo, e nada era o que se entendia.

MARGOT: Que singelo. 
NORAH: E cansativo. Sobretudo, cansativo. Que não tenho mais o fôlego de antes. (ela suspira e Norah sempre às risadas).

MARGOT: É fantástico, poderiam fazer parte do show de variedades do Le

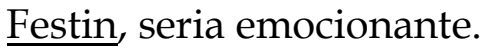

NORAH: Não me venhas com emocionante.

MARGOT: Ele chorou?

(-pausa- Olham-se atentamente)

NORAH: Chorou.

(Margot às gargalhada)

NORAH: Copiosamente. Felizmente não exigiu que eu chorasse também, todavia julguei que chegaria a chorar, igualmente.

MARGOT: A poesia te emocionou, Norah. (cínica e às risadas)

NORAH: Tu ris? Pois saibas que ele quer a ti. Ouviste bem? O poeta quer ter contigo, Margot. E te digo mais: é daqueles homens ressentidos de tudo por tudo. Como pode alguém rebelar-se com tantas posses e conforto? A vida é muito irônica mesmo.

MARGOT: (ela cessa as risadas e olha Norah enigmaticamente) Sei de algo pior.

NORAH: Se sabes guarda para ti, que não quero saber de nada pior do que este poeta, que isto já me bastou por hoje.

MARGOT: Sei de alguém que muito te quer.

NORAH: És tu?

MARGOT: Também e tão bem.

NORAH: No final de tudo o poeta soube muito bem compensar, não precisarei sair por pelo duas semanas.

MARGOT: Não precisarás sair, e ainda assim sairás.

(elas riem juntas maliciosamente)

NORAH: (reflexiva) Mas há algo diferente em sair por opção e não por condição, não é mesmo?

MARGOT: Conheço alguém que faria da opção uma constante para ti.

NORAH: Por que sinto que estás a me conduzir a um cadafalso?

MARGOT:Não confias em mim, minha Norah? 
NORAH: Nem um pouco. (elas riem freneticamente)

\section{CENA V}

(Pierre e Norah se olham em silêncio durante 5 minutos, nenhuma fala, nenhum apelo sonoplástico, apenas se olham durante 5 minutos)

\section{CENA VI}

(Norah está na mesma posição da sena anterior, Margot entra quebrando o silêncio)

MARGOT: Dormi com o poeta... Que homem mais insuportável Norah.

(-pausa-Margot observa Norah, ela permanece na mesma posição)

NORAH: (Sem olhar para Margot) Sei de algo pior.

MARGOT: (reflexiva) Sei que sabes.

(Margot senta no divã diante de Norah, elas se olham)

MARGOT: (reflexiva) Eu queria dizer essas frases com palavras que fossem precisas. Eu já não sei mais qual é a melhor forma de exprimir essa ideia. Eu sabia, mas, agora eu já não sei mais.

(Norah levanta bruscamente como se acordasse de um transe)

NORAH: Comeste?

MARGOT: Não.

NORAH: Tens fome?

MARGOT: Sempre.

NORAH: E eu também.

(Norah toma do vestido, do carmim, oferece a Margot para que se preparem para saientra música, a luz se apaga)

São Paulo, 13 de janeiro de 2012. 
OUTROS TEXTOS ESCRITOS POR PATUSCA AO LONGO DO PROCESSO

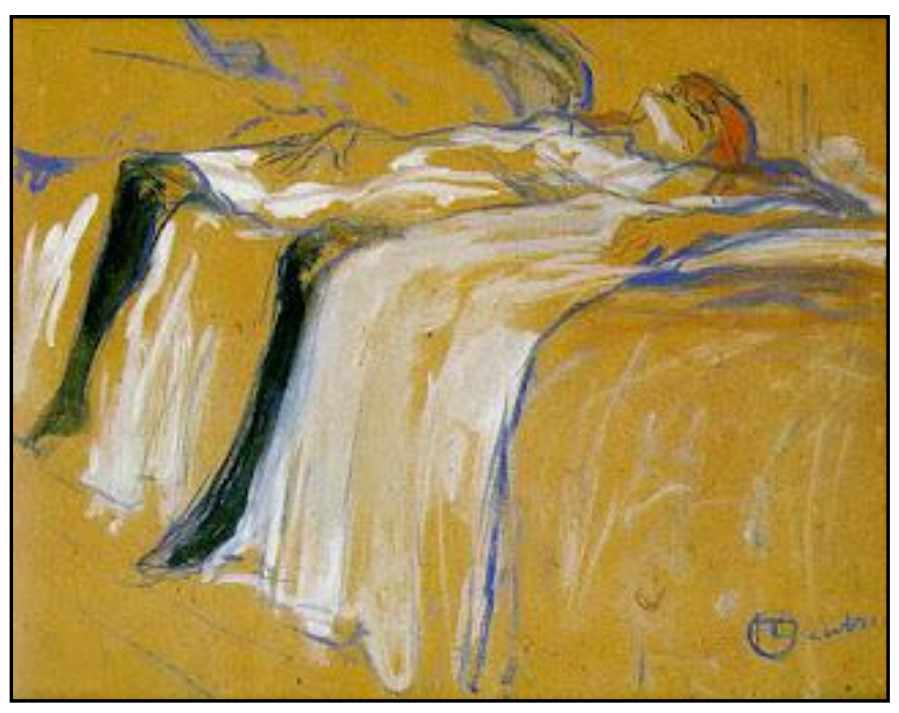

Cena 1 - Acordar: "Essa mulher que acordou vestida desse jeito, com traje de baile, de ressaca, mas feliz, satisfeita. Ela deu uma 'rapidinha', ébria, com o homem por quem está apaixonada, não foi trabalho, foi prazer. Um homem que não a ama, e que não quis amanhecer ao seu lado, por isso foi algo rápido, abrupto, um levantar de saias $e$ anáguas às pressas, depois de muita insistência e investidas despudoradas da parte dela, efeito do excesso de absinto. Por isso ela acorda se perguntando se a noite anterior foi apenas um sonho ou de fato aconteceu, algo que ela se dá conta quando encontra o lenço do seu amado, esquecido entre a desordem dos lençóis e vestidos espalhados no leito em que desperta. Não foi sonho. Ela se espreguiça, languida, num misto de satisfação e indisposição, e quando tenta levantar cai ao pé da cama, tonta, se dá conta que não tem noção das horas. Ela levanta, caminha até a janela, e quando afasta as cortinas, se assusta. Pela claridade que invade o quarto, ela já sabe que está atrasada para cumprir com o seu oficio, esse trabalho que segundo alguns especialistas, representa a mais antiga das profissões."

O lavabo: "E DE REPENTE se achou bonita, enxergou a beleza de toda aquela corpulência despadronizada, da incongruência de seus contornos, dos traços vulgares de seu rosto tão comum, reconheceu uma beleza diferente, deliciosa, algo transformador, que vinha de dentro, impalpável, misterioso, não eram os olhos, era o olhar, não eram os lábios ou os dentes, era o sorriso, nem mesmo era a voz ou as formas, mas o jeito de falar, a maneira singular de gesticular.

Ela queria a si, e por isso passou a compreender o que tanto os olhos dele a cercavam. Era linda, era plena, sem medidas de comparação porque não havia

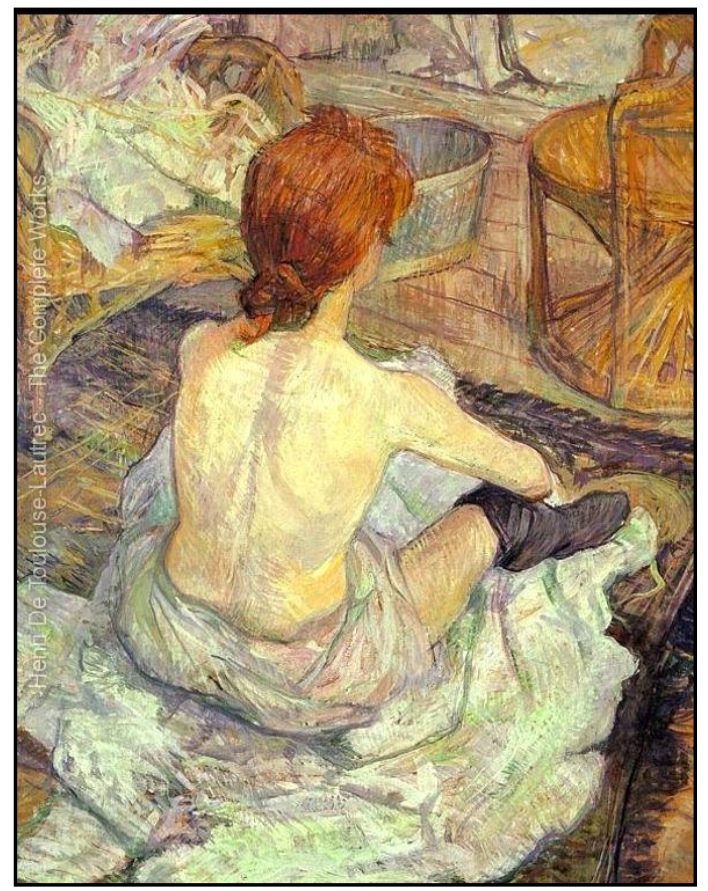


com o que comparar, única.

E sua estima por si foi de um arrebatamento tão absurdo que chegou a desdenhá-lo no seu intimo, não o desejava mais, desejava a si, era a si que queria, se agradar, se cortejar, se tocar. Deleitava-se consigo mesma, e às vezes que se dava a ele, era em prol de satisfazer-se, e ele quando a recebia era tomado por igual propósito: satisfaze-la, como se aquele ser merecesse tudo, simplesmente por existir, por ser excelso, por ser de uma beleza inexplicável e sobrenatural, que aviltava todas as normas do que era tido como belo, violentando os conceitos de uma época, livre de qualquer regra ou ditadura, ela era a própria obra, extraordinária, parnasiana, bela por ser bela; e assim sentia, e por isso o era.

E a redoma de sua auto-estima era uma fortaleza tão segura que ela não precisava propagar sua descoberta com palavras, nem gestos artificialmente dosados, ela apenas era, apenas sentia, sentia e sabia, e a ciência disso era a sua força, e tanto acreditou que tornou-se fato, e o fato foi mais que fato, foi realidade concreta.

Eis sua nova condição, e somente agora dava-se conta, sempre estivera ali e nunca notara, sofrera tanto, e só a partir de então sentia-se bem dentro de si, antes tarde do que mais tarde. Era essa a sua nova vida; e ele, eles, todos, regozijados por serem vencidos, venturosos.

Não havia desdém, não havia porquês, nem dúvidas ou desconfianças alheias que se fizessem perceptíveis, ela era imune a tudo, não havia elogio que lhe tocasse a vaidade, nem uma declaração arrebatada as suas qualidades a alterava, mesmo que gestual, mesmo muda, era consciente de si, as lisonjas não a iludiam.

Apenas ela existia, os demais representavam parte da composição, ela se bastava, podia ficar consigo por uma eternidade, e tudo fora de si era tão somente doce curiosidade. Não era do mundo, o mundo é que era dela. E por se amar e se estimar tanto é que era tão amada e estimada pelos demais. Nem uma presença a perturbava, e ela era pura paz, natural em sua extravagância, própria em sua insolente alegria, sedutoramente senhora de si.

Não competia, porque não havia por que competir, nem com as tolas vaidades do seu sexo, nem com os mesquinhos jogos de poder do sexo oposto, não lograva ganhar, ela não era jogo, nem disputa, muito menos aposta, ela era vitória. E curiosamente, assim mesmo, conseguia amar as pessoas, o mundo e as coisas, sem malícia, sem ferir, sem maldade ou arrogância, com respeito, grandeza, grata de tudo, sem ciúmes, livremente, sem possessividade, sem invasão, era amor, não paixão, paixão era pela vida, por si mesma, por sua própria existência, amava os demais, mas primeiramente amava-se, e justamente era essa liberdade que aprisionava os demais em torno de si e dos seus mais inocentes caprichos, sempre atendidos, sempre cedidos, sempre rendidos a ela. 
Sem fastio da vida, sem tédio dos dias, ela era a própria vida, o motivo, o cerne de tudo. Finalmente encontrava-se, explorava-se com prazer, curiosa por si, ávida, apaixonada pela nova descoberta; infinitamente feliz. Satisfeita dentro do próprio corpo, que outrora desdenhara de forma tão cruel; mas isso foi se fora, sonho mau, bruma cada vez mais distante, felizmente acordara.

E agora possuía a chave de todas as portas, o segredo de todas as fortunas:

Ela.

Por ela.

Para ela

Em prol dela."

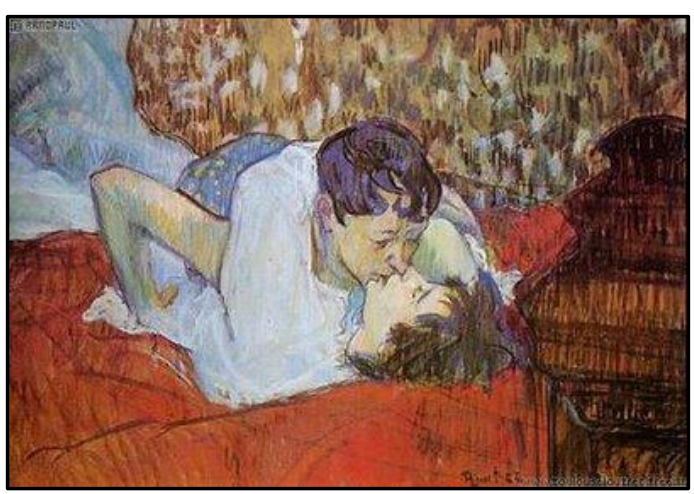

"São tuas as minhas noites de quarta, quinta $e$ sexta, meu corpo, meu sangue e suor. E são teus os meus pensamentos e o meu desejo durante todas as noites da minha semana."

\section{PESQUISA HISTÓRICA}

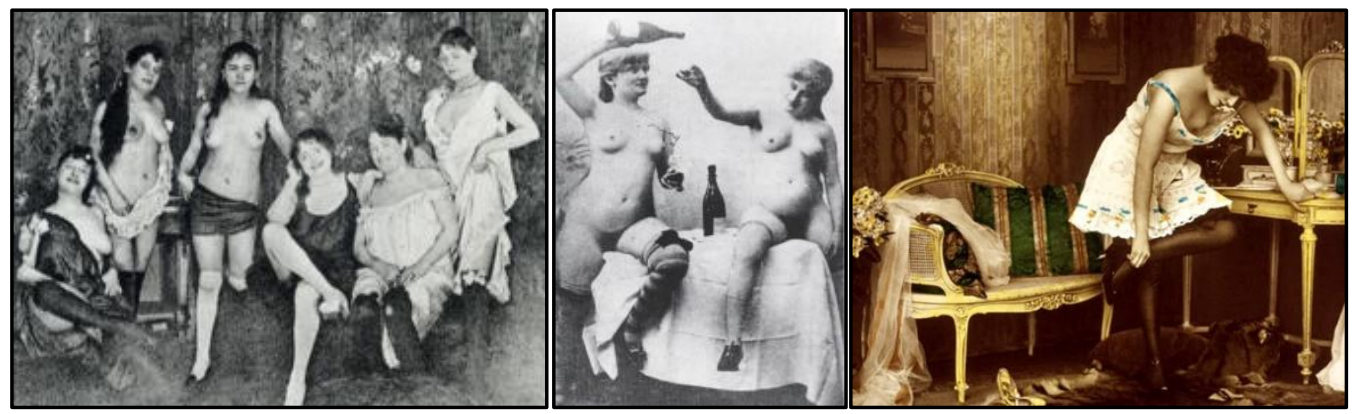

Anexo 47: Bordel parisiense, duas insoumises da época e um quarto típico - FINAL DO SÉC. XIX.

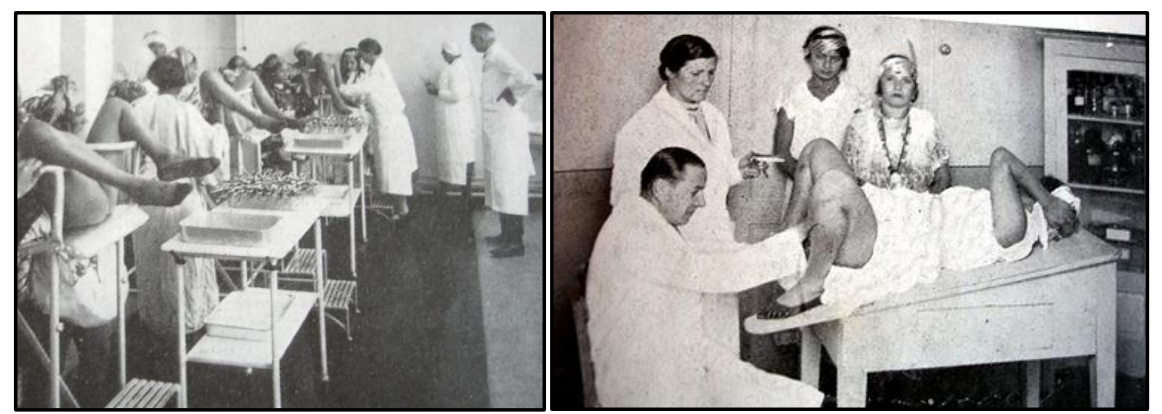

Anexo 48: Registro histórico - A INSPEÇÃO MÉDICA 